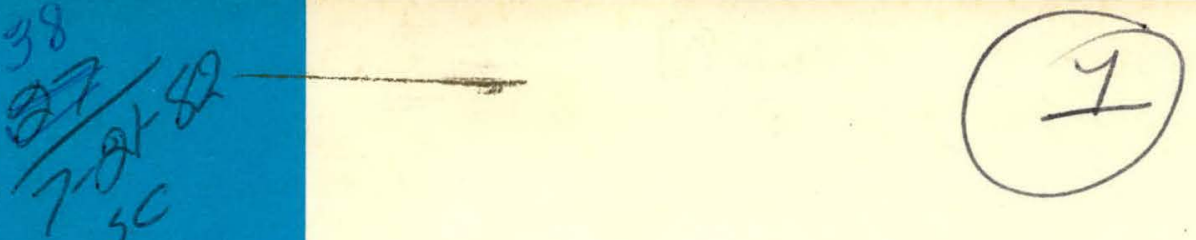

\title{
REDOX REACTIONS INVOLVING CHROMIUM, PLUTONIUM, AND MANGANESE IN SOILS
}

FINAL REPORT

FOR THE PERIOD

1 JULY 1978 TO 30 SEPTEMBER 1981

MICHAEL C. AMACHER AND DALE E. BAKER

JUNE 1982

WORK PERFORMED UNDER CONTRACT

DE-AS08-77DP04515

(FORMERLY DE-AC02-77DO-4515.A006)

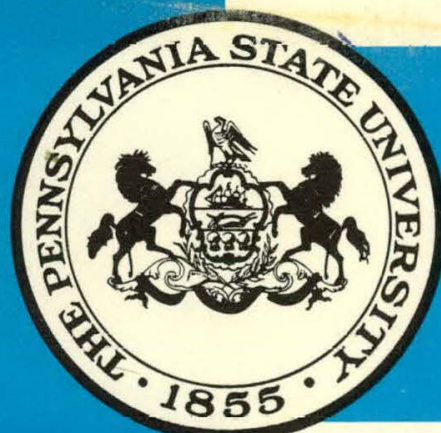

INSTITUTE FOR RESEARCH 


\section{DISCLAIMER}

This report was prepared as an account of work sponsored by an agency of the United States Government. Neither the United States Government nor any agency Thereof, nor any of their employees, makes any warranty, express or implied, or assumes any legal liability or responsibility for the accuracy, completeness, or usefulness of any information, apparatus, product, or process disclosed, or represents that its use would not infringe privately owned rights. Reference herein to any specific commercial product, process, or service by trade name, trademark, manufacturer, or otherwise does not necessarily constitute or imply its endorsement, recommendation, or favoring by the United States Government or any agency thereof. The views and opinions of authors expressed herein do not necessarily state or reflect those of the United States Government or any agency thereof. 


\section{DISCLAIMER}

Portions of this document may be illegible in electronic image products. Images are produced from the best available original document. 


\section{DISCLAIMER}

This report was prepared as an account of work sponsored by the United States Government. Neither the United States nor the United States Department of Energy, nor any of their employees, makes any warranty, express or implied, or assumes any legal liability or responsibility for the accuracy, completeness, or usefulness of any information, apparatus, product, or process disclosed, or represents that its use would not infringe privately owned rights. Reference herein to any specific commercial product, process, or service by trade name, mark, manufacturer, or otherwise, does not necessarily constitute or imply its endorsement, recommendation, or favoring by the United States Government or any agency thereof. The views and opinions of authors expressed herein do not necessarily state or reflect those of the United States Government or any agency thereof.

Printed in the United States of America.

Available from the National Technical Information Service, U. S. Department of Commerce, Springfield, Virginia 22161.

\section{Price: Printed Copy A08 Microfiche A01}

Codes are used for pricing all publications. The code is determined by the number of pages in the publication. Information pertaining to the pricing codes can be found in current issues of the following publications, which are generally available in most libraries: Energy Research Abstracts, (ERA); Government Keports Announcements and Index (GRA and I); Scientitic and lechnical Abstract Reports (STAR); and publication, NTIS-PR-360 available from (NTIS) at the above address.

\footnotetext{
The Pennsylvania State University, in compliance with federal and state laws and regulations governing affirmative action and nondiscrimination, does not discriminate in the recruitment, admission, and employment of students, faculty, and staff in the operation of any of its educational programs and activities as defined by law. Accordingly, nothing in this publication should be viewed as directly or indirectly expressing any limitation, specification, or discrimination as to race, religion, color, or national origin; or to handicap, age, sex, or status as a disabled or Vietnam-era veteran, except as provided by law. Inquiries concerning this policy may be directed to the Affirmative Action Officer.
} 
DOE/DP/04515---2

DE82 021130

REDOX REACTIONS INVOLVING CHROMIUM,

PLUTONIUM, AND MANGANESE IN SOILS*

FINAL REPORT

FOR THE PERIOD

1 JULY 1978 TO 30 SEPTEMBER 1981

MICHAEL C. AMACHER AND DALE E. BAKER

JUNE 1982

THE PENNSYLVANIA STATE UNIVERSITY

INSTITUTE FOR RESEARCH ON LAND AND WATER RESOURCES

UNIVERSITY PARK, PA 16802

PREPARED FOR THE

U.S. DEPARTMENT OF ENERGY

DIVISION OF ENERGY TECHNOLOGY

UNDER CONTRACT DE-AS08-77DP04515

(FORMERLY DE-AC02-77DP04515.A006)

\footnotetext{
"This publication was submitted to the Graduate School, The Pennsy/vania State University, by M. C. Amacher as a thesis in Soil Chemistry in partial fulfillment of the requirements for the degree of Doctor of Philnsnpihy. August. 1981.
} 


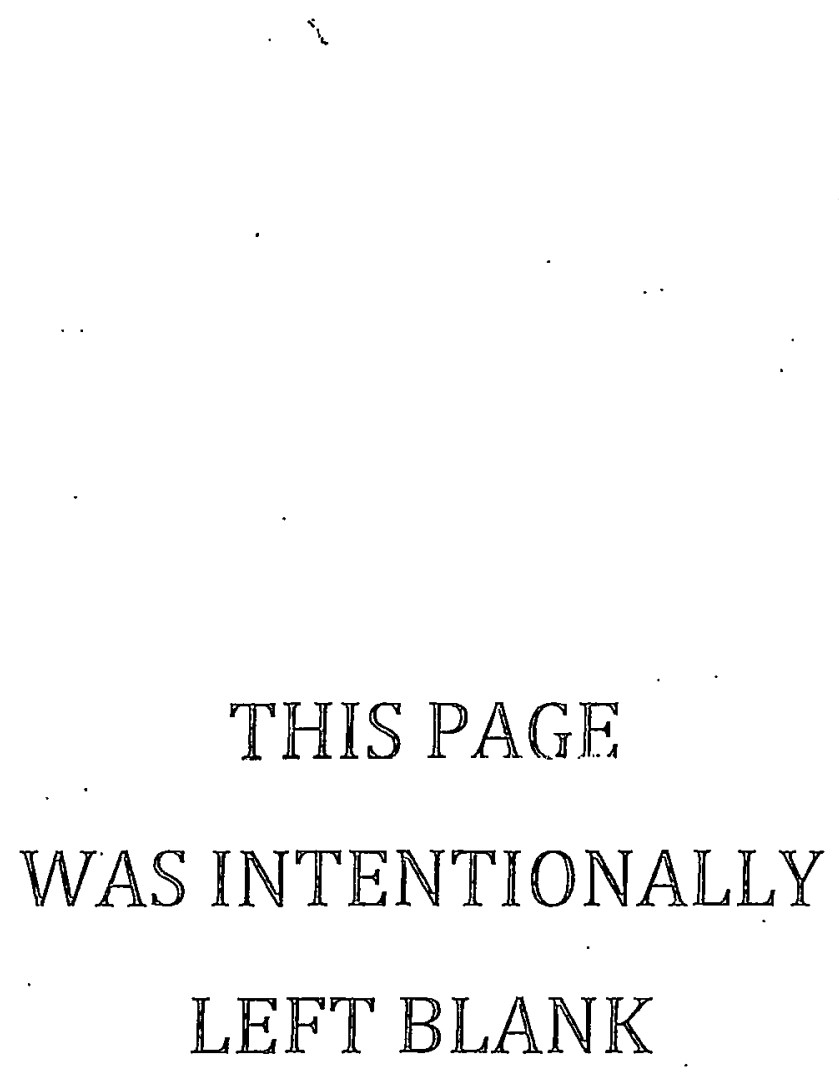


As a result of atmospheric testing of nuclear devices at the Nevada Test Site in southern Nevada, the soll and vegetation of several areas on the test site are contaminated with transuranic elements, particularly Pu and Am. Although particulate movement through wind and water erosion is the most important mechanism. of dispersion of $\mathrm{Pu}$ at the test site, dispersion of water-soluble species may also be occurring. Under the direction of the Nevada Applied Ecology Group of the U.S. Department of Energy, a program is being developed to monitor the dispersion and bioavailability of transuranics, especially plutonium, in the environment.

However, because Pu is toxic, usually insoluble, not uniformly distributed in the soil, and can exist in four oxidation states in the enVironment, it is very difficult to study. Therefore, Cr reactions in soil were 1nvestigated as a possible general model for $\mathrm{Pu}$ reactions in soil, since it was postulated that the redox chemistries of the two elements should be similar. An evaluation of data from the literature Indicated that the reduced forms of both elements are usually relatively immobile in solls while the oxidized forms are usually relatively mobile and hence more bioavailable. The redox chemistries appear to be controlled by organic matter, minerals containing Fe(II), and manganese oxides. Thermodynamic calculations revealed that both elements should be highly soluble in the presence of manganese oxides. In addition the solubility of Pu can be enhanced by radiolytic oxidation. Reduction of both elements by organic matter and oxidation of $\mathrm{Cr}$ by manganese oxides in soils have been demonstrated, and it was postulated that the conditions necessary for oxidation of $\mathrm{Pu}$ by manganese oxides exist in Nevada Test Site soils. 
Chemical fractionation methods were used to determine the redox states of $\mathrm{Pu}$ in a Nevada. Test Site soil and the amounts of Pu associated with various soil components in order to deduce possible reactions between the various $\mathrm{Pu}$ specles and soll components so that weathering and dispersion by chemical mechanisms can be predicted. Chemical fractionation and kinetics experiments were performed to study reactions of Cr with soil, manganese oxides, and fulvic ac1ds in order to provide Information to eventually develop a qualitative, predictive model for Pu behavior in soil.

The fractionation of soll Pu revealed that only a few percent of the total soll $\mathrm{Pu}$ was associated with organic matter and/or iron oxides with the remainder prohahly existing as etable $\mathrm{PuO}_{2}$. Oxidized $\mathrm{Pu}$ was found in the soil, but the presence of oxidized Pu appeared to be due to Pu dissolved by the extracting solutions reacting with the soil manganese oxides. The amount of oxidized $\mathrm{Pu}$ found was a very small fraction of the total soil $\mathrm{Pu}$, although carbonate-rich waters dissolving $\mathrm{PuO}_{2}$ in the presence of manganese oxides could result in oxidized $\mathrm{Pu}$ leaching through the soll profile.

Chemical fractionation revealed that $C_{r}$ from organic sources such as sewage sludge remained in soil in a reduced state associated with the organic matter or perhaps organo- $\mathrm{Cr}$ complexes sorbed to iron oxides and was not oxidized by manganese oxides. Inorganic saurces of $\mathrm{Cr}\left(\mathrm{CrCl}_{3}\right.$, $\mathrm{Cr}(\mathrm{OH})_{3}$, and $\mathrm{Cr}_{2} \mathrm{O}_{3}$ ) were oxidi zed in soil, but only a few perrent of the added $\mathrm{Cr}$ was oxidized while the remainder was sorbed by the various soil components (organic matter and iron oxides, etc.) and apparently was unavaliable for oxidation. Although complete oxidation was predicted, not all the solution $\operatorname{Cr}$ (III) was oxidized because the $\operatorname{Mn}$ (IV) at the 
surfaces of the manganese oxide minerals was "used up" and access of $\operatorname{Cr}$ (III) to Mn(IV) beneath the mineral surface was blocked by $\operatorname{Mn}$ (II) remalning sorbed to the mineral. The initial rate of oxidation was extremely rapid followed by a rapid fall-off in oxidation rate as surface $\mathrm{Mn}(I V)$ was used up. At low temperature and $\mathrm{pH}$ levels the oxidation reaction was sufficiently slowed down to follow zero-order kinetics. Reduction of $\operatorname{Cr}(V I)$ in soil and by fulvic actd was found to be slow and followed first-order kinetics. Reduction was rapid only at low $\mathrm{pH}$ levels. Therefore, Immediate $\mathrm{Cr}$ avallability is probably controlled through oxidation by manganese oxides while long-term control is probably exerted through reduction by organic matter.

Qualitatively, it appears that $C r$ reactions in sofl could be used.. as a general model for Pu reactions in soil although important differences exist. Chief among these is the radioactivity of Pu which can affect the reactions of this element in soils. 
ABSTRACT. . . . ................... 111

LIST OF TABLES. . . . . . . . . . . . . . . . . vili

LIST OF FIGURES . . . . . . . . . . . . . . . . . . x

ACKNOWLEDGMENTS . . . . . . . . . . . . . . . . x1i1

INTRODUCTION. . . . . . . . . . . . . . . . . . I

THEORETICAT CONSIDERATIONS. . . . . . . . . . . . . . . 10

Stability of Chromium and Plutonium Species

In Aqueous Environments. . . . . . . . . . . . . 10

Radiolycic Oxidation and $\mathrm{PuO}_{2}$ Microsphere

Dissolution Studies. . . . . . . . . . . . . . . 19

Thermodynamics of Chromium and Plutonium

Oxidation by Manganese Oxide Minerals. . . . . . . . . 25

Additional Evidence for the Oxidation of

Plutonium by Manganese Oxide Minerals

in Soll Environments ................ . . 34

Hypothesis and objectives................ 36

MATERIALS AND METHODS. . . . . . . . . . . . . . . . 38

Plutonium Experiments. . . . . . . . . . . . . . 38

So1l Sample Collection. . . . . . . . . . . . . 38

Chemical Fractionation of 9011 Pu and Am. . . . . . . . 38

Oxidation of Carbonate-Soluble Pu . . . . . . . . . . 42

Pu Valence State Separat1on Methods . . . . . . . . . 42

Chromium Experiments .. . . . . . . . . . . . . . 45

Soll Sample Collection and Characterization . . . . . 45

Preparation of $\mathrm{MnO}_{2}$ Minerals. . . . . . . . . 47

Extraction of Fulvic Acid from Leather Dust

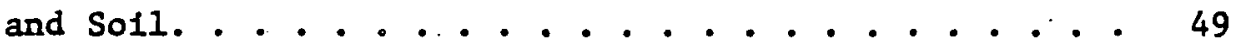

Chemical Fractionation of Soil $\mathrm{Cr}$ and Mn. . . . . . 50

Fate of $C_{r}$ from Sludge and Leather Dust

Applied to Soll in Laboratory Incubation

Experiments .................. 53

Effect of Drying, Storage Time, and Organic

Matter Removal on the Ability of Soil

to Uxidize Cr . . . . . . . . . . . . . . . . 54

C. Oxidizing Capally of Soll. . . . . . . . . . . 56

Effect of Cr Concentration on Cr Oxidation by Soll ................... 56

Extractability of $\mathrm{Cr}(\mathrm{VI})$ with $\mathrm{KH}_{2} \mathrm{PO}_{4}$. . . . . . . . . 57

Oxidation of Cr from Different Sources at

Selected Concentrations in Soil with Time... . . . 59

Kineties of $\mathrm{Cr}$ Oxidation by Moist

Hagerstown Silt Loam. . . . . . . . . . . 60 
Page

Kinetics of $\mathrm{Cr}$ Oxidation by $\mathrm{MnO}_{2}$ Minerals. ....... 64 Rinetics of $\mathrm{Cr}$ Oxidation by $\delta-\mathrm{MnO}_{2}$ in the

Presence of Fulvic Actd and the Kinetics of $\mathrm{Cr}$ and Mn Reduction by Fulvic Acid. . . . . . . 68

RESULTS AND DISCUSSION ..................... . . 71

Plutonium Experiments ................... 71

Chemical Fractionation of Soll Pu. . ......... 71

Extraction of Soll $\mathrm{Pu}(\mathrm{V} / \mathrm{VI})$. . . . . . . . . . 76

Oxidation of Carbonate-Soluble Pu. . . ....... 80

Extraction of Soll Am. . . . . . . . . . . . . 80

Chromium Experiments. . . . . . . . . . . . . . . 82

Chemical Fractionation of Soll $\mathrm{Cr}$ and Mn . . . . . . 82

Fate of $\mathrm{Cr}$ from Sludge and Leather Dust

Applied to Soll in Laboratory

Incubation Experiments .............. 90

Effect of Drying, Storage Time, and Organic

Matter Removal on the Ability of Soll

to Oxidize Cr. . . . . . . . . . . . . . . 94

Effect of Cr Concentration on Cr Oxidation

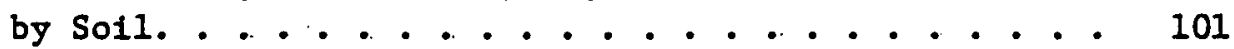

Cr Oxidizing Capacity of Soll. . . . . . . . . . 105

Extractability of Soll $\mathrm{Cr}(\mathrm{VI})$ with $\mathrm{KH}_{2} \mathrm{PO}_{4} \cdot$. . . . . . 105

Oxidation of Cr from Different Sources at

Selected Concentrations in Soll with Time. . . . . . 114

Rinetics of Cr Oxidation and Sorption by

Moist Hagerstown Silt Loam . . . . . . . . . . . 121

Kinetics of $\mathrm{Cr}$ Oxidation by $\mathrm{MnO}_{2}$ Minerals. . . . . . . 126

Kinetics of $\mathrm{Cr}$ Oxidation by $\delta-\mathrm{MnO}_{2}$ in the

Presence of Fulvic Acid and the Kinetics

of $\mathrm{Cr}$ and Mn Reduction by Fulvic Acid. . . . . . . . 146

SUMMARI AND CONCLUSIONS. . . . . . . . . . . . . . 156

LITERATURE CITED . . . . . . . . . . . . . . 163 
LIST OF TABLES

Table

$\underline{\text { Page }}$

1 Reactions and equilibrium constants used to

construct stability diagrams............. 13

2 Summary of ${ }^{239} \mathrm{PuO}_{2}$ dissolution studies. . . . . . . 20

3 oxidation or reduction half-reactions involving

$\mathrm{Cr}, \mathrm{Mn}$, and Pu. . . . . . .......... 26

4 Radioactive contamination survey of fourteen soil

samples collected fivim Areas 11A, 11B, 11C, and

110 of the NTS. . . . . . . . . . . . 39

5 Properties of $\mathrm{MnO}_{2}$ minerals . . . . . . . . . . . 48

6 Conditions for experiments un lie effect of soil/solution ratio on extraction of soil

$\mathrm{Cr}(\mathrm{VI})$ by $\mathrm{KH}_{2} \mathrm{PO}_{4}$. . . . . . . . . . . . . . . 58

7 Summary of reaction conditions for experiments

on the kinetics of $\mathrm{Cr}$ oxidation by moist

Hagerstown silt loam. . . . . . . . . . . . . 61

8 Summary of reaction conditions for experiments

on the kinetics of $\mathrm{Cr}$ oxidation by manganese

oxide minerals. ................. . . 65

9 Summary of reaction conditions for experiments

on the kinetics of $\mathrm{Cr}$ oxidation in the presence

of fulvic acid and the kinetics of $\mathrm{Cr}$ and $\mathrm{Mn}$

reduction by fulvic actd............. 69

10 Plutonium extracted from a soil sample from

Area 11C (NTS) using various extracting

reagents. . . . . . . . . . . . . . . . . 72

11 Plutonium extracted from a soil sample from

Area IIC (NTS) using various extracting

reagents. ................... 77

12 Oxidation of $\mathrm{Na}_{2} \mathrm{CO}_{3}$ soluble $\mathrm{Pu}$ in a soll

sample Irum Area. $11 \mathrm{C}$ (NTS) using $\delta-\mathrm{MnO}_{2} \ldots . . . . . . .81$

13 Effect of extraction time on $\mathrm{Na}_{2} \mathrm{CO}_{3}$ extractable

Pu in a soll sample from Area IIC (NTS) . . . . . . . 81

14 Americtum extracted from a soil sample from

Area IIC (NTS) using various extracting reagents. . . . 83 
LIST OF TABLES (Continued)

$\underline{\text { Table }}$

Page

15 Water content $\left(\theta_{\mathrm{dw}}\right), \mathrm{pH}$, and organic matter (O.M.) content of collected Hagerstown silt loam and Murrill silt loam samples. . . . . . . . .

16 Chromiun in $0.5 \mathrm{M} \mathrm{NaOH}$ extractable organic matter from sludge and moist Hagerstown silt loam and Murrill silt loam amended with sludge. . . . . 84

17 Chemical fractionation of soll $\mathrm{Cr}$. . . . . . . . 85

18 Chemical fractionation of soil . . . . . . . . 88

19 Total and NaOC1 extractable $\mathrm{Cr}$ in moist Hagerstown silt loam amended with sludge. . . . . . . . 89

20 Total and NaOCl extractable $\mathrm{Cr}$ in air-dried Hagerstown silt loam amended with sludge. . . . . . .

21. Potassium phosphate extraccable $\operatorname{Cr}(\mathrm{VI})$ in molst Hagerstown silt loam samples treated with sludge and leather dust in laboratory incubation studies .... .

22 Sodium hypochlorite extractable $\mathrm{Cr}$ in molst Hagerstown silt loam samples treated with sludge and leather dust in laboratory incubation studies....

23. Chromium oxidizing ability of Hagerstown, Murrill, and Chrome soils as affected by drying, storage t1me, and organic matter removal. . . . . . . . . 95

24. Effect of water removal by various treatments on the Cr oxidizing ability of Murrill silt loam . . . . . 100

25 Chromium(VI) extracted from moist Hagerstown silt loam using varfous concentrations of $\mathrm{KH}_{2} \mathrm{PO}_{4}$ in solution. . . 108

26 Effect of soil/solution ratio on the $\mathrm{KH}_{2} \mathrm{PO}_{4}$ extraction of $\mathrm{Cr}$ (VI) from moist Hagerstown silt loam. Soil/solution ratio varied by holding soil amount constant while varying $\mathrm{KH}_{2} \mathrm{PO}_{4}$ solution volume . . . . . 110

27 Effect of varying $\mathrm{Cr}$ (III) concentration on the oxidation of $\mathrm{Cr}$ in molst Murrill silt loam with time . . . 115

28 Effect of $\operatorname{Cr}$ (III) source and amount on the oxidation of $\mathrm{Cr}$ in moist Hagerstown silt loam with time . . . . 118

29. Potassium phosphate extractable $\operatorname{Cr}(\mathrm{VI})$ in moist Hagerstown silt loam amended with $\mathrm{Cr}_{2} \mathrm{O}_{3}$. . . . . . . 120 
1 Examples of normal $\mathrm{Pu}$ distributions in two NTS soil profiles............... 3

2 Examples of abnormal Pu distributions in three NTS soil profiles.............. 4

3 Stability of $\mathrm{PuO}_{2}$ in $10^{-12} \mathrm{M} \mathrm{Pu}$ at $25^{\circ} \mathrm{C}, 10^{-3.5}$ atm $\mathrm{CO}_{2}$, and 1 atm total pressure assuming radiolytic oxidation is not occurring ......... 12

4 Stability of $\mathrm{PuO}_{2}$ in $10^{-8} \mathrm{M} \mathrm{Pu}$ at $25^{\circ} \mathrm{C}, 10^{-3.5}$ atm, and 1 atm total pressure assuming radiolytic oxidation is occurring............. 16

5 Stability of $\mathrm{Cr}(\mathrm{OH})_{3}$ and $\mathrm{Cr}_{2} \mathrm{O}_{3}$ in $10^{-6} \mathrm{M} \mathrm{Cr}$ at $25^{\circ} \mathrm{C}$ and 1 atm total pressure. . . . . . . . . 18

6 Solubility of $\mathrm{PuO}_{2}$ as controlled by $\delta-\mathrm{MnO}_{2}$ in the absence of reducing agents at $250 \mathrm{C}, 10^{-3} .5$ atm $\mathrm{CO}_{2}$, and 1 atm total pressure assuming radiolytic oxidation is not occurring . . . . . . . . 29

7 Solubility of $\mathrm{PuO}_{2}$ as controlled by $\delta-\mathrm{MnO}_{2}$ in the absence of reducing agents at $25^{\circ} \mathrm{C}, 10^{-3.5}$ atm $\mathrm{CO}_{2}$, and 1 atm total pressure assuming radiolytic oxidation is occurring ........... 31

8 Solubility of $\mathrm{Cr}(\mathrm{OH})_{3}$ as controlled by $\delta-\mathrm{MnO}_{2}$ in the absence of reducing agents at $25^{\circ} \mathrm{C}$ and 1 atm total pressure ................ 33

9 Experimental apparatus for studying the kinetics of $\mathrm{Cr}$ oxidation by moist Hagerstown silt loam and manganese oxide suspensions. ........... 63

10 Effect of varying $\operatorname{Cr}($ III) concentrations on the fraction of added $\mathrm{Cr}$ that is sorbed or oxidized by moist Hagerstown silt loam. . . . . . . . . . 102

11 Effect of varying $\mathrm{Cr}$ (III) concentrations on the amount of soil solution total $\mathrm{Cr}$ and $\mathrm{Cr}$ (VI), $\mathrm{KH}_{2} \mathrm{PO}_{4}$ extractable $\mathrm{Cr}$ (VI), and total $\mathrm{Cr}(\mathrm{VI})$ produced in moist Hagerstown silt loam. . . . . . . . 104

12 Exhaustion of $\mathrm{Cr}$ oxidizing capacity of moist Hagerstown silt loam . . . . . . . . . . . 106

13 Successive $\mathrm{KH}_{2} \mathrm{PO}_{4}$ extractions of $\mathrm{Cr}(\mathrm{VI})$ from moist Hagerstown silt loam treated with three levels of $\operatorname{Cr}($ III). . . . . . . . . . . . . 109 
LIST OF FIGURES (Continued)

Figure

$\underline{\text { Page }}$

14 Effect of soil/solution ratio on $\mathrm{KH}_{2} \mathrm{PO}_{4}$ extraction of $\mathrm{Cr}(\mathrm{VI})$ from moist Hagerstown silt loam. Soil/solution ratio varied by holding $\mathrm{KH}_{2} \mathrm{PO}_{4}$ solution volume constant while varying soil amount. . . . . . . . . . . . . 112

$15 \mathrm{KH}_{2} \mathrm{PO}_{4}$ extraction of $\mathrm{Cr}(\mathrm{VI})$ from moist Hagerstown silt loam at constant soil/solution ratio . . . . 113

16 Kinetics of $\mathrm{Cr}$ oxidation in molst Murrill silt loam. . . . . . . . . . . . . . . . 117

17 Kinetics of $\mathrm{Cr}$ sorption by moist Hagerstown silt loam. . . . . . . . . . . . . . . 122

18 Effect of temperature on the kinetics of $\mathrm{Cr}$ oxidation in moist Hagerstown silt loam. . . . . . . 123

19 Effect of organic matter removal on the kinetics of $\mathrm{Cr}$ oxidation in moist Hagerstown silt loam. . . . . 125

20 Effect of temperature on the kinetics of $\mathrm{Cr}$ oxidation by $\delta-\mathrm{MnO}_{2}$ at $\mathrm{pH}$ 5.5. . . . . . . . . . . . 127

21 Effect of $\mathrm{pH}$ on the kinetics of $\mathrm{Cr}$ oxidation by $\delta-\mathrm{MnO}_{2}$. .................. 130

22 Effect of temperature on the kinetics of $\mathrm{Cr}$ oxidation by $\delta-\mathrm{MnO}_{2}$ at $\mathrm{pH} 1.0 . . . . . . . . . . .132$

23 Kinetics of $\mathrm{Cr}(\mathrm{OH})_{3}$ oxtdarton by $\delta-\mathrm{MnO}_{2}$ at

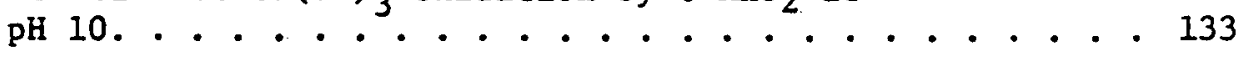

24 Effect of ionic strength on the kinetics of Cr oxidation by $\delta-\mathrm{MnO}_{2} \ldots . . . . . . . . . . .135$

25 Effect of solution composition on the kinetics of $\mathrm{Cr}$ oxidation by $\delta-\mathrm{MnO}_{2}$. . . . . . . . . . . . . 136

26 Effect of varying amounts of $\delta-\mathrm{MnO}_{2}$ on the kinetics of $\mathrm{Cr}$ oxidation by $\delta-\mathrm{MnO}_{2}$......... 138

27 Kinetics of $\mathrm{Cr}$ oxidation by $\delta-\mathrm{MnO}_{2}$ and $\mathrm{Mn}$ reduction by $\mathrm{Cr}$ (III) with excess $\mathrm{Cr}$ present. . . . . . 139

28 Effect of temperature on the kinetics of Mn reduction by $\mathrm{Cr}$ (III) at $\mathrm{pH} 1.0$ with excess Cr present . . . . . . . . . . . . . . . . 141 
29 Kinetics of $\mathrm{Cr}$ oxidation by various $\mathrm{MnO}_{2}$ minerals under selected conditions . . . . . . . . 142

30 Effect of temperature on $\mathrm{OH}^{-}$demand during $\mathrm{Cr}_{r}$ oxidation and sorption in moist Hagerstown silt loam . . . . . . . . . . . . . . . 144

31 Effect of temperature on $\mathrm{OH}^{-}$demand during Cr oxidation by $\delta-\mathrm{MnO}_{2}$. . . . . . . . . . . . . 145

32 Kinetics of $\mathrm{Cr}$ reduction in moist Hagerstown sllt loam. . . . . . . . . . . . . . . . 147

33 Effects of temperature and $\mathrm{pH}$ on the kinetics of $C_{r}$ reduction by soll fulvic ac1d. . . . . . . . 148

34 Effects of temperature and $\mathrm{pH}$ on the kinetics of $\mathrm{Cr}$ reduction by leather dust fulvic acid, . . . . . 150

35 Kinetics of $\mathrm{Cr}$ oxidation by $\delta-\mathrm{MnO}_{2}$ in the presence of leather dust fulvic acid over a short time period ................... . 152

36 Kinetics of $\mathrm{Cr}$ oxidation by $\delta-\mathrm{MnO}_{2}$ in the presence of leather dust fulvic acid over a long time period . . . . . . . . . . . . . . . . 153

37 Kinetics of $\mathrm{Mn}$ reduction by leather dust fulvic acid . . . . . . . . . . . . . . . . 154 Idealized diagram of $\mathrm{Pu}$ reactions in soil. . . . . . 158 


\section{ACKNOWLEDGMENTS}

The author wishes to express his gratitude to Dr. Dale E. Baker, thesis adviser, for his guidance, assistance, and evaluation throughout the program of study. Grateful appreciation is also extended to Dr. Arthur Rose and Dr. K. K. S. Pillay for their involvement in the NAEG project and their review of this thesis program.

Recognition is also extended to Dr. William Steele, Dr. Les Lanyon, and Dr. Robert Hamilton for their review of the thesis program.

Grateful appreciation is also extended to the Department of Agronomy and the Institute for Research on Land and Water Resources for providing the research facilities, and to Paul Dunaway and the Nevada Applied Ecology Group for providing financial support for the project.

A special note of thanks is due the following people: Ernest Bondietti at Oak Ridge National Laboratory for providing laboratory training to the author in the area of plutonium chemistry; Nancy. Daugherty and Roger Granlund of Health Physics for providing $\alpha$-counting Instrumentation; Hollis Berry and Ed Eubanks of Reynolds Electrical and Engineering $C o$. for assisting in the collection of soil samples at the Nevada Test Site; and Elizabeth Douglass for assistance with the laboratory experiments on chromium. 
As a result of atmospheric nuclear and non-nuclear explosions, numerous areas of the Nevada Test Site (NTS) in southern Nevada are contaminated with plutonium (Pu) and other transuranic elements. The Nevada Applied Ecology Group (NAEG) was established by the Atomic Energy Commission to study the problems associated with the contamination of NTS soils by $\mathrm{Pu}$ and other transuranic elements. The objectives of the NAEG are to:

1. Delineate locations contaminated by transuranics;

2. Determine concentrations of transuranics in ecosystem components;

3. Quantify rates of movement of transuranics among ecosystem components ;

4. Evaluate radiological hazards of $\mathrm{Pu}$;

5. Identify areas which need to be cleaned up or treated; and 6. Develop techniques for cleanup or treatment.

To assist the NAEG in meeting objectives 2 and 3 a program to monitor the dispersion and bioavallability of transuranics, and especially $\mathrm{Pu}$, in the NTS soils is needed.

There are several mechanisms of $\mathrm{Pu}$ dispersion in the desert environment of the NTS. The major mechanisms of dispersion which are active in moving $\mathrm{PuO}_{2}$ particles are wind erosion, water erosion, $\mathrm{PuO}_{2}$ particles sifting vertically through a soil profile due to gravity, and mass flow of water moving through a soil profile. Of these, wind erosion is considered by the NAEG to be the most important mechanism through which $\mathrm{Pu}$ is transported both on and off site. The minor mechanisms of dispersion which are active in moving soluble $\mathrm{Pu}$ species are mass flow of water 
moving through a soil profile and diffusion through the soil water. In addition to these mechanisms the activities of microorganisms and burrowing animals can also disperse $\mathrm{Pu}$.

Bioavailability in this text refers to root uptake of $\mathrm{Pu}$ species. Plutonium can be delivered to plant roots by three mechanisms: mass flow, diffusion, and root interception. These mechanisms were originally proposed by Barber (1962) to explain root uptake of essential elements, but are also applicable to Pu. Mass flow and diffusion are dispersion processes while root interception Involves roots coming into contact with soil particles contaminated with Pu while growing through the soil profile. The Pu can be taken up by the roots when root exudates dissolve the contaminated particles. Any or all of these mechanisms may be operating within a given soil profile.

Most of the available data from NTS soil and plant studies indicate that $\mathrm{Pu}$ shows 11ttle dispersion and low bloavailability in NTS soils (White and Dunaway (eds.), 1975, 1976, 1977a, 1977b, 1978). The dispersion that does occur is mostly due to particle transport by wind and water with wind transport being the most important. However, there are some anomalous data suggesting the presence of a more mobile Pu species within certain soil profiles at the NTS. Essington et al. (1976) have described normal Pu distributions (see Figure 1) within several NTS soil profiles. Normal Pu distributions are those in which $95 \%$ or more of the soil's pluconfum is in the cop $\mathrm{g} \mathrm{cm}$ of soll with the remalnder decreas= ing curvilinearly with depth. In contrast with this are abnormal Pu distributions within the soil profile such as those illustrated in Figure 2, also taken from Essington et a1. (1976). 


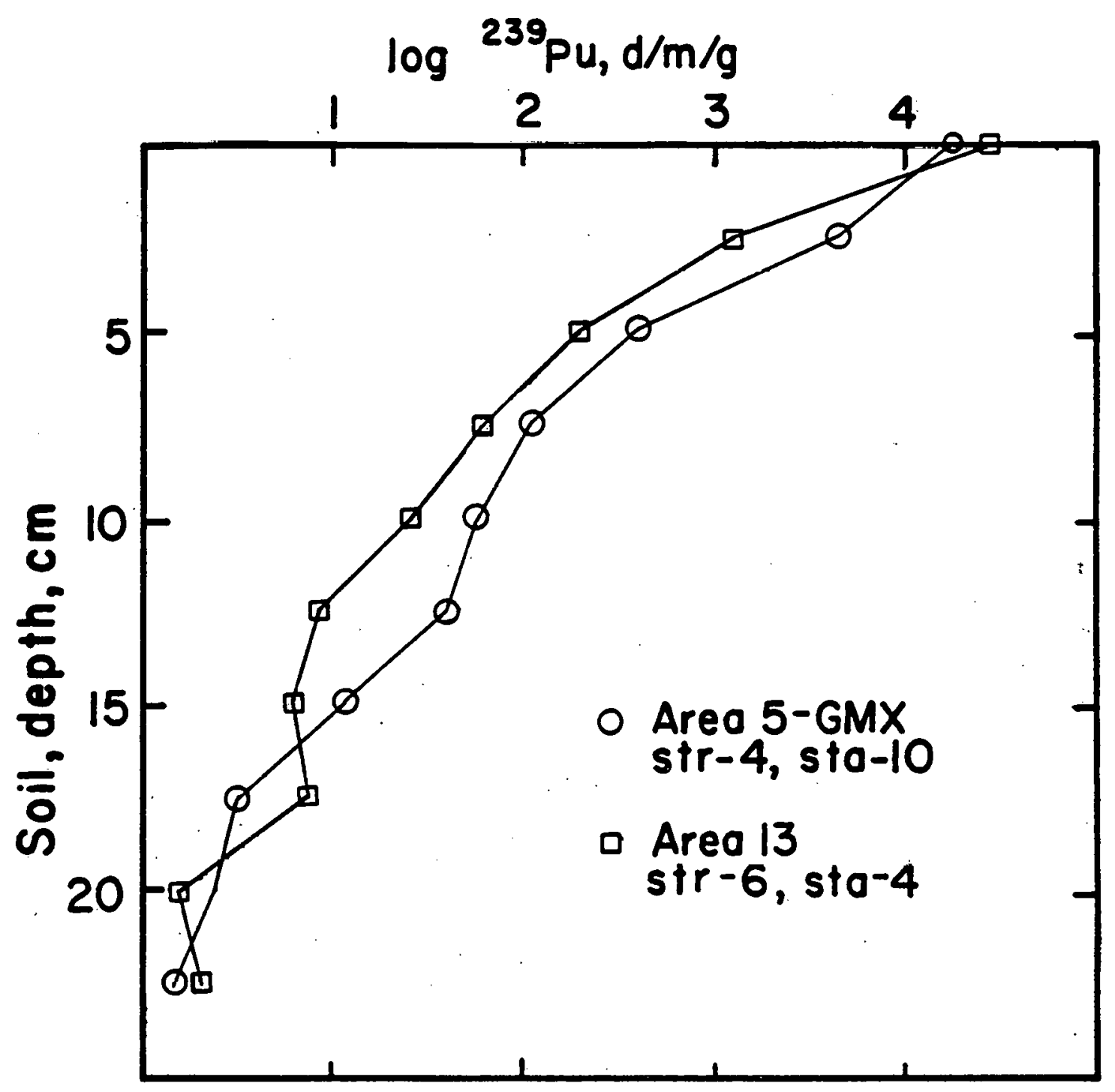

Figure 1. Examples of normal Pu distributions in two NTS soil profiles. 


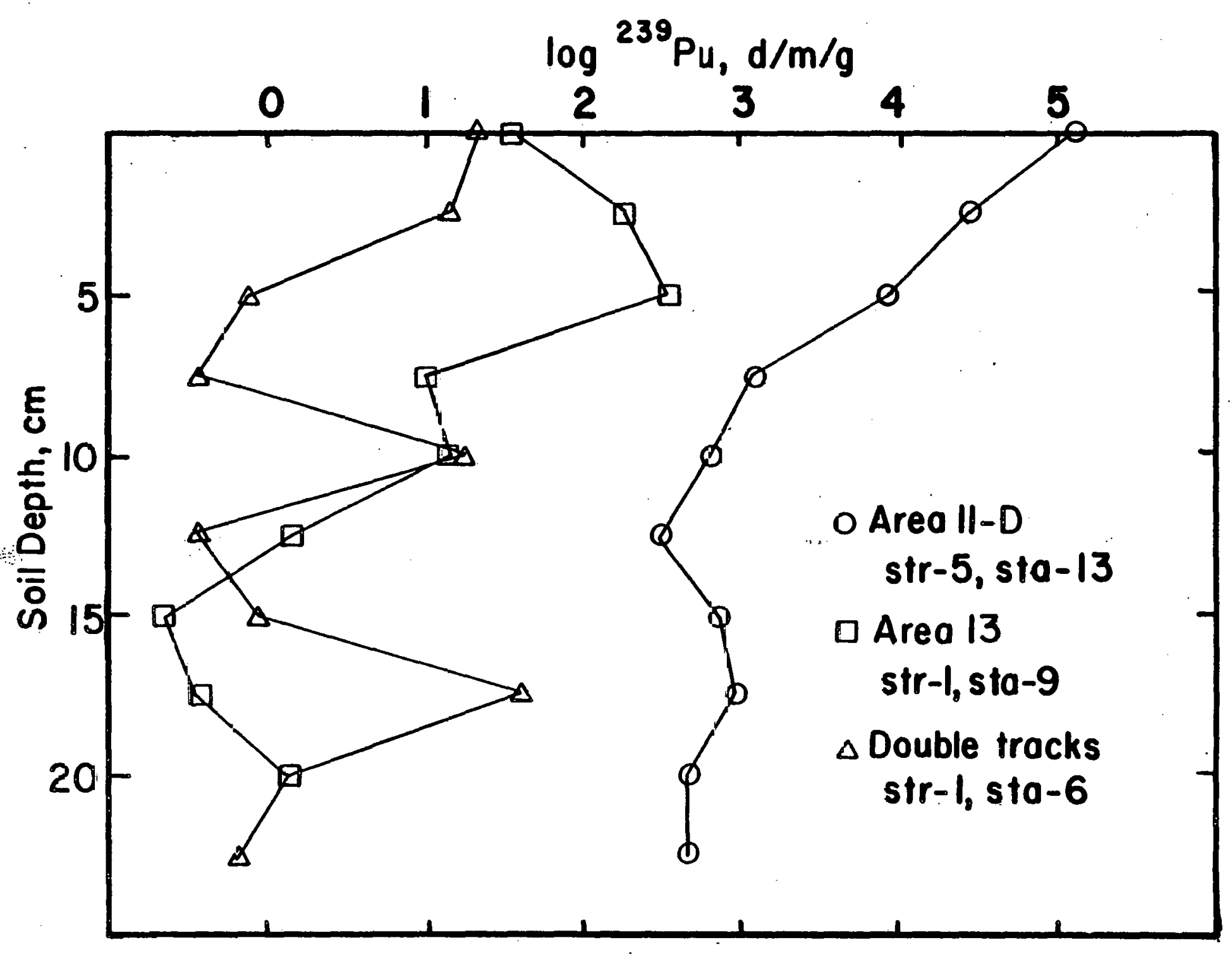

Figure 2. Examples of abrormal Pu distributions in three NTS soll profiles. 
Abnormal profiles are those in which the $\mathrm{Pu}$ concentration is quite variable with depth, movement is strongly inhibited, or generally less than $95 \%$ of the $\mathrm{Pu}$ appears. in the top $5 \mathrm{~cm}$. The data from Area $11 \mathrm{D}$ and Double Tracks indicate substantial $\mathrm{Pu}$ migration with depth. This migration could be due to the movement of colloidal $\mathrm{Pu}$ or due to movement of soluble Pu species. It is this last possibility that this thesis will consider.

Plutonium is capable of existing in four oxidation states in normal aqueous environments (Cleveland, 1970), but Francis et al. (1976, Agronomy Abstracts, p. 128) have demonstrated using soil thin-layer chromatography that $\mathrm{Pu}(\mathrm{V} / \mathrm{VI})$ species are far more mobile than $\mathrm{Pu}(\mathrm{IV})$ species. This is not surprising since Jacobson and Overstreet (1948) originally showed that $\mathrm{Pu}$ in lower valence states is more strongly sorbed to calcium bentonite than $\mathrm{Pu}$ in higher valence states. This stronger retention of lower valence $\mathrm{Pu}$ by soil minerals has been confirmed by Rai et al. (1979, Agronomy Abstracts, p. 151). Therefore, it seems likely that any mobile Pu species in the soils of the NTS would be $\mathrm{Pu}(\mathrm{V} / \mathrm{VI})$. Because the soils of the NTS are calcareous ( $\mathrm{pH} 7$ to 8.3) (Leavitt, 1970), the $\mathrm{Pu}(\mathrm{VI})$ spectes, $\mathrm{PuO}_{2} \mathrm{CO}_{3} \mathrm{OH}^{-}$, has been proposed (Baker et al., 1978) as the soluble Pu species in NTS soils, since this species is thought to be stable under such conditions (Rai and Serne, 1977).

The dominant $\mathrm{Pu}$ solid phase in certain NTS soils is thought to be $\mathrm{PuO}_{2}$ (Tamura, 1974), which means $\mathrm{Pu}$ is quadrivalent in this mineral. In order for $\mathrm{PuO}_{2} \mathrm{CO}_{3} \mathrm{OH}^{-}$to be produced, $\mathrm{PuO}_{2}$ would have to be oxidized. Oxidation of $\mathrm{Pu}$ (IV) by $\mathrm{O}_{2}$ is so slow that it can be ignored (Cleveland, 1970; Bondietti, personal communication). One way for $\mathrm{PuO}_{2} \mathrm{CO}_{3} \mathrm{OH}^{-}$to be 
produced is through radiolytic oxidation of $\mathrm{PuO}_{2} \cdot$ Radiolytic oxidation of $\mathrm{PuO}_{2}$ has been discussed by Rai, Serne, and Swanson (1980), Bondietti and Reynolds (1976), and Bondietti and Sweeton (1977). Radiolytic oxidation is important for larger $\mathrm{PuO}_{2}$ particles ( $150 \mu \mathrm{m}$ ), but is probably not important for dispersed, submicron $\mathrm{PuO}_{2}$ particles in the environment (Bondietti and Sweeton, 1977). In soils the most likely oxidizing agent is manganese oxide minerals (Baker et al., 1978). Therefore, the following hypothesis was proposed: under high Eh conditions, high $\mathrm{HCO}_{3}^{-}$levels, low organic macter levels and negligible $\mathrm{Fe}$ (II) levels, $\mathrm{PuO}_{2}$ particles can be oxidized to the mobile $\mathrm{PuO}_{2} \mathrm{CO}_{3} \mathrm{OH}^{-}$ species by the manganese oxide minerals in a soil profile. Low organic matter levels and negligible $\mathrm{Fe}$ (II) levels are neccosary, since these are good reducing agents for oxidized $\mathrm{Pu}$ (Cleveland, 1970; Bondietti et al., 1975). The conditions necessary for this oxidation reaction to occur were postulated to exist within soil profiles at the NTS. One of the main objectives of this thesis was to study the redox chemistry of $\mathrm{Pu}$ in selected soil samples from the NTS by demonstrating the exlscence of oxldized $\bar{P} u$ species in these soils and by determining the amount of $\mathrm{Pu}$ associated with various soil components (organic matter and $\overline{F e}$ and $M$ oxides) by means of chemical fractionation methods. However, the soil chemistry of Pu is difficult tu sludy because of the toxicity, very low solubility, multiple oxidation states, and helerogenenus distriburion of this element within the soil profile. Therefore, a possible course of action would be to study another element whose redox chemistry in soils is similar to $\mathrm{Pu}$ under similar conditions, but is easier to work with. The redox chemistry of this element could then be used as a general model for the redox chemistry of $\mathrm{Pu}$. Chromium ( $\mathrm{Cr}$ ) 
is an element whose redox chemistry in soils probably is sufficiently similar to that of $\mathrm{Pu}$, so that it could be used as a general model for Pu.

Certain findings in the literature on $\mathrm{Cr}$ (Bartlett and Kimble, 1976a; Bartlett and James, 1979) and on Pu (Rai and Serne, 1977; Rai et al., 1979, Agronomy Abstracts, p. 151; Rai, Serne, and Swanson, 1980; Bondietti and Sweeton, 1977; Bondietti and Reynolds, 1976; Francis et a1., 1976, Agronomy Abstracts, p. 128; Jacobson and Overstreet, 1948; Cleveland, 1970) led to the following conclusions by the author regarding the similarities between $\mathrm{Cr}$ and $\mathrm{Pu}$ behavior in aqueous environments:

1. Both elements can exist in multiple oxidation states in normal aqueous environments. Chromium can exist in trivalent and hexavalent states, while $\mathrm{Pu}$ can exist in trivalent, quadrivalent, pentavalent, and hexavalent states;

2. Both elements can exist as cationic or anionic species in normal aqueous environments. Trivalent $\mathrm{Cr}$ exists as the cation, $\mathrm{Cr}^{3+}$, and its hydrolysis products, or as the anion, $\mathrm{CrO}_{2}^{-}$, at very low concentrations. Hexavalent $\mathrm{Cr}$ exists as the dichromate, $\mathrm{Cr}_{2} \mathrm{O}_{7}^{2-}$, or chromate, $\mathrm{HCrO}_{4}^{-}$or $\mathrm{CrO}_{4}^{2-}$, anions depending upon the pH. Plutonium has cationic forms such as $\mathrm{Pu}^{3+}$ and $\mathrm{PuO}_{2}^{+}$and anionic forms such as $\mathrm{PuO}_{2} \mathrm{CO}_{3} \mathrm{OH}^{-}$;

3. Trivalent $\mathrm{Cr}$ and $\mathrm{Pu}(\mathrm{III} / \mathrm{IV})$ cations are usually relatively "Immobile" in normal aqueous environments, since they are strongly sorbed to soil components and hence are not readily bioavailable. On the other hand, $\mathrm{Cr}(\mathrm{VI})$ and $\mathrm{Pu}(\mathrm{VI})$ anions are usually relatively "mobile" in normal aqueous environments, since they are not as strongly sorbed to soil components 
and hence are more readily bioavailable;

4. Hexavalent chromium and $\mathrm{Pu}(\mathrm{V} / \mathrm{VI})$ species are thermodynamically stable under approximately the same chemical environments in solution; and

5. Both elements can be oxid1zed by soll manganese oxides. The oxidation of $\operatorname{Cr}$ (III) to $\mathrm{Cr}(\mathrm{VI})$ by soil manganese oxides is thermodynamically possible in most soil environments and has actually been observed in soils. This reaction occurs despite the presence of organic matter that would tend to keep $\mathrm{Cr}$ in the trivalent state. Oxidized Pu species have been observed in natural waters, the oxidation of $\mathrm{Pu}($ IV) by manganese oxide miperals is thermodynamically possible in many soil environments, and the oxidation of $\mathrm{Pu}\left(\right.$ IV) by $\mathrm{MnO}_{2}$ has been observed in the laboratory.

In pointing out the simflarities between $\mathrm{Cr}$ and $\mathrm{Pu}$ behavior in aqueous environments, it must be remembered that there are also many differences between the two elements and analogies cannot be overextended. Chief among these differences is the radioacitivity of $\mathrm{Pu}$ that can lead to radiolytic effects which are absent with Cr. Nevertheless, the simflarities led to the hypothesis that eome aspects of $\mathrm{Cr}$ redox chemistry in soils could be used as a general model for $\mathrm{Pu}$ redox chemistry. Therefore, the other objective of this thesis was to study the redox chemlstry of $\mathrm{Cr}$ in the soil environment in order to provide information for the development of a general model for the redox chemistry of $\mathrm{Pu}$ in the soil.

Redox reactions involving $\mathrm{Cr}$ in the soil are also important in their own right, since improper land disposal of chromium-containing 
wastes such as wastes from the metal finishing industry might result in oxidation of $\operatorname{Cr}$ (III) by soil manganese oxides which are widely distributed and eventual contamination of water supplies with hexavalent chromium. Hexavalent chromium is toxic to aquatic life and is a suspected human carcinogen (EPA, 1980).

Eventually studies such as these may form the basis for developing programs to monitor the dispersion and bioavallability of any element that exists in different oxidation states in various soil environments. 
THEORETIAL CONSIDERATIONS

\section{Stability of Chromium and Plutonium Species}

\section{in Aqueous Environments}

All four oxidation states of $\mathrm{Pu}$ can coexist in solution under certain conditions (Cleveland, 1970). Because $\mathrm{Pu}$ does have four oxidation states, the behavior of trace quantities of $\mathrm{Pu}$ in natural waters and soils is difficult to study. Numerous authors (Bondietti and Swettul, 1977; Rai and Serne, 1977; Rai, Serne, and Swanson, 1980) have studied the problem of $\mathrm{Pu}$ spectation and solubility fin aqueous environments, and have presented solubility and stalllity fleld diagrams for Pu solid phases and soluble species in an attempt to predict the behavior of $\mathrm{Pu}$ in soils.

Generally, these authors agree that under acid-reducing conditions $\mathrm{Pu}^{3+}$ is the most stable species in solution. Under oxidizing conditions the situation is not as clear due to lack of rellable equilibrium constants for some reactions between various $\mathrm{Pu}$ species. Recently, Rai, Serñe, and Swanson (1980) have shown by means of an Eh-pH diagram constructed using newly available thermodynamic data that $\mathrm{PuO}_{2}^{+}$is the most stable Pu species in solution in oxidizing environments. Instead of showing distinct boundary lines between stability fields on their Eh-pH diagram, Rai, Serne, and Swanson (1980) drew the boundaries as shaded regions to indlcate the uncertainties in the equilibrium constants. They did not consider hydroxide or carbonate complexes of $\mathrm{Pu}$ because they felt the equilibrium constants for the formation of these species were too uncertain for inclusion in the diagram. However, the failure to include these hydroxide and carbonate $\mathrm{Pu}$ species in the diagram may be a serious error, since these species may be the most stable under 
oxidizing conditions, regardless of the uncertainties in the thermodynamic data. Because one does not have reliable thermodynamic data-for a species, that does not mean the species does not exist or is unimportant. In an earlier paper, Rai and Serne (1977) prepared solubility diagrams for various aqueous plutonium species and solid Pu phases. They showed that under oxidfzing conditions $\mathrm{PuO}_{2} \mathrm{CO}_{3} \mathrm{OH}^{-}$is the most stable Pu species although the reliability of its formation constant is suspect and that $\mathrm{PuO}_{2}$ is the most stable solid phase.

Keeping in mind the uncertainties in the equilibrium constants (they may vary by as much as a few orders of magnitude) a stability diagram for $\mathrm{PuO}_{2}$ in $10^{-12} \mathrm{M} \mathrm{Pu}$ at $25^{\circ} \mathrm{C}, 10^{-3.5}$ atm $\mathrm{CO}_{2}$, and 1 atm total pressure is presented in Figure 3. For details on the construction of Eh-pH stability diagrams the reader is referred to Garrels and Christ (1965). The equilibrium constants used in the construction of this diagram were taken from Rai and Serne (1977) and are presented in Table 1. Plutonium oxide was chosen as the solid phase, since it is the most stable (Rai and Serne, 1977; Rai, Serne, and Moore, 1980), and is also thought to be the predominant Pu solid phase in the soils of the NTS. A solution $\mathrm{Pu}$ concentration of $10^{-12} \mathrm{M}$ was chosen because this represents the upper limit of $\mathrm{Pu}$ concentrations found in solution in natural waters contaminated with $\mathrm{Pu}$ (Bondietti and Sweeton, 1977). Concentrations between $10^{-12}$ and $10^{-17} \mathrm{M}$ have been observed (Bondietti and Sweeton, 1977). A temperature of $25^{\circ} \mathrm{C}$ was chosen since most stability diagrams are drawn at this temperature, although daytime temperatures in the sumer at the NTS greatly exceed this. The $\mathrm{CO}_{2}$ concentration of $10^{-3.5}$ atm represents the level commonly found in the atmosphere although levels of up to $10^{-1}$ atm have been observed in the soil atmosphere 


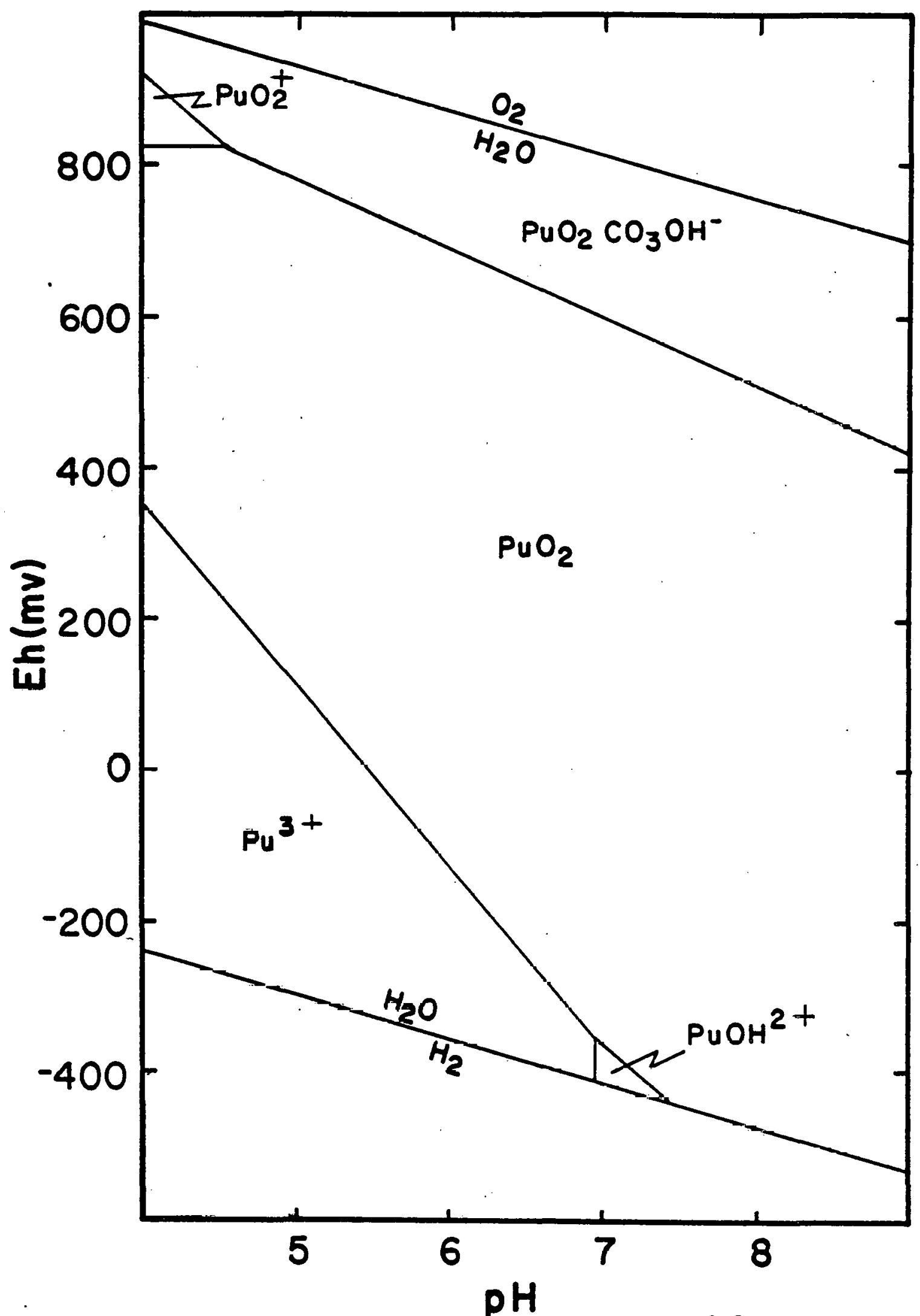

Figure 3. Stability of $\mathrm{PuO}_{2}$ in $10^{-12} \mathrm{M} \mathrm{Pu}$ at $25^{\circ} \mathrm{C}, 10^{-3.5}$ atm $\mathrm{CO}_{2}$, and 1 atm total pressure assuming radiolytic oxidation is not occurring. 
Table 1. Reactions and equilibrium constants used to construct stability diagrams.

Constants calculated from data listed in Rai and Serne (1977).

\section{$\underline{\text { Reaction }}$}

$\underline{\log \mathrm{K}_{25^{\circ} \mathrm{C}}}$

$\mathrm{PuO}_{2}+4 \mathrm{H}^{+}+\mathrm{e}^{-}=\mathrm{Pu}^{3+}+2 \mathrm{H}_{2} \mathrm{O}$

$\mathrm{PuO}_{2}+3 \mathrm{H}^{+}+\mathrm{e}^{-}=\mathrm{PuOH}^{2+}+\mathrm{H}_{2} \mathrm{O}$

$\mathrm{PuO}_{2}=\mathrm{PuO}_{2}^{+}+\mathrm{e}^{-}$

$\mathrm{PuO}_{2}+\mathrm{CO}_{2}+2 \mathrm{H}_{2} \mathrm{O}=\mathrm{PuO}_{2} \mathrm{CO}_{3} \mathrm{OH}^{-}+3 \mathrm{H}^{+}+2 \mathrm{e}^{-}$

$\mathrm{Pu}^{3+}+\mathrm{H}_{2} \mathrm{O}=\mathrm{PuOH}^{2+}+\mathrm{H}^{+}$

$\mathrm{PuO}_{2}^{+}+\mathrm{CO}_{2}+2 \mathrm{H}_{2} \mathrm{O}=\mathrm{PuO}_{2} \mathrm{CO}_{3} \mathrm{OH}^{-}+3 \mathrm{H}^{+}+\mathrm{e}^{-}$

Constants calculated from data listed in Rai and Serne (1977); Rai, Serne, and Moore (1980); and Rai, Serne, and Swanson (1980).

$$
\begin{array}{lc}
\mathrm{PuO}_{2}+4 \mathrm{H}^{+}+\mathrm{e}^{-}=\mathrm{Pu}^{3+}+2 \mathrm{H}_{2} \mathrm{O} & \frac{\log \mathrm{K}_{25} \mathrm{O}^{\mathrm{C}}}{20.8} \\
\mathrm{PuO}_{2}+3 \mathrm{H}^{+}+\mathrm{e}^{-}=\mathrm{PuOH}^{2+}+\mathrm{H}_{2} \mathrm{O} & 14.8 \\
\mathrm{PuO}_{2}=\mathrm{PuO}_{2}^{+}+\mathrm{e}^{-} & -14.8 \\
\mathrm{PuO}_{2}+\mathrm{CO}_{2}+2 \mathrm{H}_{2} \mathrm{O}=\mathrm{PuO}_{2} \mathrm{CO}_{3} \mathrm{OH}^{-}+3 \mathrm{H}^{+}+2 \mathrm{e}^{-} & -39.4 \\
\mathrm{Pu}^{3+}+\mathrm{H}_{2} \mathrm{O}=\mathrm{PuOH}^{2+}+\mathrm{H}^{+} & -6.0 \\
\mathrm{Pu}^{3+}+2 \mathrm{H}_{2} \mathrm{O}=\mathrm{PuO}_{2}^{+}+4 \mathrm{H}^{+}+2 \mathrm{e}^{-} & -35.6 \\
\mathrm{PuO}_{2}^{+}+\mathrm{CO}_{2}+2 \mathrm{H}_{2} \mathrm{O}=\mathrm{PuO}_{2} \mathrm{CO}_{3} \mathrm{OH}^{-}+\mathrm{e}^{-} & -24.6
\end{array}
$$


when a great deal of microbial activity is-occurring.

The upper and lower lines on the diagram define the stability field for water. The stability field for $\mathrm{PuO}_{2}$ predominates over a very wide range in Eh and $\mathrm{pH}$. Soil solutions with Eh and $\mathrm{pH}$ values within the $\mathrm{PuO}_{2}$ field will have $\mathrm{PuO}_{2}$ as the most stable phase under the conditions defined on the diagram although other phases such as $\mathrm{Pu}(\mathrm{OH})_{4}$ may exist metastably to $\mathrm{PuO}_{2}$. Under reducing conditions $\mathrm{Pu}^{3+}$ and $\mathrm{PuOH}^{2+}$ are the most stable spectes as indicated by the diagram. The $\mathrm{Pu}^{4+}$ ion and its hydrolysis species are so insoluble that they do not appear on the diagram. Under highly oxidizing conditions and at low $\mathrm{pH}$ the most stable species is $\mathrm{PuO}_{2}^{+}$. The stability field for $\mathrm{PuO}_{2}^{+}$would occupy a much wider range of $\mathrm{Eh}$ and $\mathrm{pH}$ if the $\mathrm{PuO}_{2} \mathrm{CO}_{3} \mathrm{OH}^{-}$species did not exist, but as the diagram indicates, $\mathrm{PuO}_{2} \mathrm{CO}_{3} \mathrm{OH}^{-}$is the most stable species under oxtdizing conditions over a wide range of $\mathrm{pH}$.

Over a pH range of 7 to 8 (most of the NTS soils fall in this range) the boundary line between $\mathrm{PuO}_{2}$ and $\mathrm{PuO}_{2} \mathrm{CO}_{3} \mathrm{OH}^{-}$ranges between 605 and $515 \mathrm{mV}$. These Eh levels are certainly achievahle in moderately well oxidized soils. At equilibrium solution $\mathrm{Pu}$ concentrations of less than $10^{-12} \mathrm{M}$, the boundary between $\mathrm{PuO}_{2}$ and $\mathrm{PuO}_{2} \mathrm{CO}_{3} \mathrm{OH}^{-}$is moved to lower Eh values. Also as the $\mathrm{CO}_{2}$ level increases, the boundary is moved to lowcr Eh values. However, one must remember that the value of the equilibrium constant used to construct the boundary between the $\mathrm{PuO}_{2}$ and $\mathrm{PuO}_{2} \mathrm{CO}_{3} \mathrm{OH}^{-}$ fields is uncertain, so that the actual position of the boundary might vary considerably from that shown on the diagram. In fact, the uncertainties in the positions of the boundaries between stability fields due to uncertainties in the data are probably far greater than changes in boundary positions due to changes in reactions conditions (different 
solution concentration, temperature, $\mathrm{CO}_{2}$ pressure).

Recently, new thermodynamic data have become available which may indicate how great the uncertainties in the data can be (Rai, Serne, and Moore, 1980; Rai, Serne, and Swanson, 1980). A stability diagram for $\mathrm{PuO}_{2}$ and solution $\mathrm{Pu}$ species was constructed using this new data and is shown in Figure 4. The reactions and constants used to prepare this diagram are listed in Table 1. The temperature and $\mathrm{CO}_{2}$ pressure conditions are the same for Figures 3 and 4 , but a soluble Pu concentration of $10^{-8} \mathrm{M}$ was chosen for the construction of Figure 4 . This level is four orders of magnitude greater than the level chosen for Figure 3 , and the $\mathrm{PuO}_{2}$ stability field in Figure 4 is still considerably smaller than the $\mathrm{PuO}_{2}$ field in Figure 3 even at this higher solution concentration. It is clear that Figure 4 predicts that $\mathrm{PuO}_{2}$ is much more soluble than: does Figure 3. Figure 4 also predicts that $\mathrm{PuO}_{2}^{+}$is much more important. than does Figure 3.

The equilibrium constants from Rai and Serne (1977) and Rai, Serne, and Swanson (1980) for reactions between the various solution Pu species are in fairly good agreement. The reason the two diagrams do not agree is the difference in equilibrium constants for the dissolution of $\mathrm{PuO}_{2} \cdot \mathrm{Rai}$, Serne, and Moore (1980) studied the dissolution of $\mathrm{PuO}_{2}$ microspheres and arrived at an experimentally determined value of -14.8 . for $\log \mathrm{K}$ for the reaction:

$$
\mathrm{PuO}_{2}=\mathrm{PuO}_{2}^{+}+\mathrm{e}^{-}
$$

Baes and Mesmer (1976) calculated a $\log \mathrm{K}$ value of -6.5 for the reaction:

$$
\mathrm{PuO}_{2}+4 \mathrm{H}^{+}=\mathrm{Pu}^{4+}+2 \mathrm{H}_{2} \mathrm{O}
$$




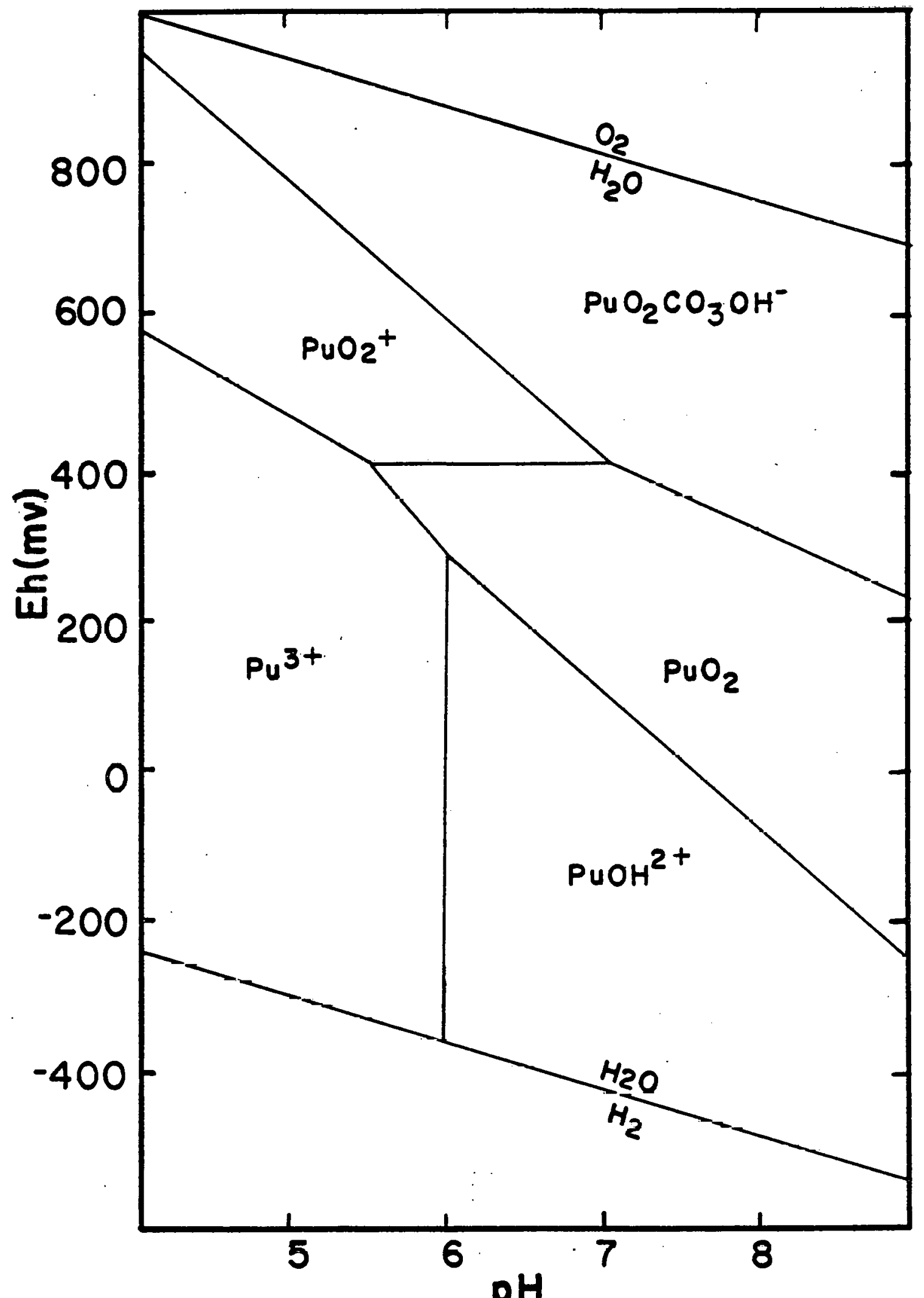

Figure 4. Stability of $\mathrm{PuO}_{2}$ at $10^{-8} \mathrm{MPu}$ at $25^{\circ} \mathrm{C}, 10^{-3.5}$ atm $\mathrm{CO}_{2}$, and 1 atm total pressure assuming radiolytic oxidation is occurring. 
based on other thermodynamic data. This value was used by Rai and Serne in their earlier paper ( $R a i$ and Serne, 1977). Adding this value to a $\log \mathrm{K}$ of -19.5 for the reaction:

$$
\mathrm{Pu}^{4+}+2 \mathrm{H}_{2} \mathrm{O}=\mathrm{PuO}_{2}^{+}+4 \mathrm{H}^{+}+\mathrm{e}^{-}
$$

leads to a $\log \mathrm{K}$ of -26.0 for the reaction:

$$
\mathrm{PuO}_{2}=\mathrm{PuO}_{2}^{+}+\mathrm{e}^{-}
$$

This value is considerably different from the experimentally determined value of -14.8. Rai, Serne, and Moore (1980) concluded that the Baes and Mesmer (1976) value was in error. However, the solubility of $\mathrm{PuO}_{2}$ microspheres as determined by Rai, Serne, and Moore (1980) does not agree with the solubility of $\mathrm{PuO}_{2}$ as determined by others (Bondietti and Reynolds, 1976; Bondietti and Sweeton, 1977; Dahlman et al., 1976). Thus, we have a probable error in the Baes and Mesmer (1976) value of several orders of magnitude since it was estimated from other thermodynamic data, uncertainties in $\mathrm{PuO}_{2}$ microsphere solubility of a few orders of magnitude, and a very large discrepancy between the Baes and Mesmer (1976) data and the $\mathrm{PuO}_{2}$ microsphere solubility. Reasons for these discrepancies are discussed in the next section on $\mathrm{PuO}_{2}$ dissolution studies.

Chromium has two oxidation states (III and VI) which can exist in normal aqueous environments. A stability diagram for $\mathrm{Cr}_{2} \mathrm{O}_{3}$ and $\mathrm{Cr}(\mathrm{OH})_{3}$ in $10^{-6} \mathrm{M} \mathrm{Cr}$ at $25^{\circ} \mathrm{C}$ and 1 atm total pressure is shown in Figure 5 . The thermodynamic data used in the construction of the diagram were taken from Garrels and Christ (1965). Over a very wide range of $\mathrm{Eh}$ and $\mathrm{pH}$ the stable solid phase for $\mathrm{Cr}$ is $\mathrm{Cr}_{2} \mathrm{O}_{3}$ although $\mathrm{Cr}(\mathrm{OH})_{3}$ would probably form 


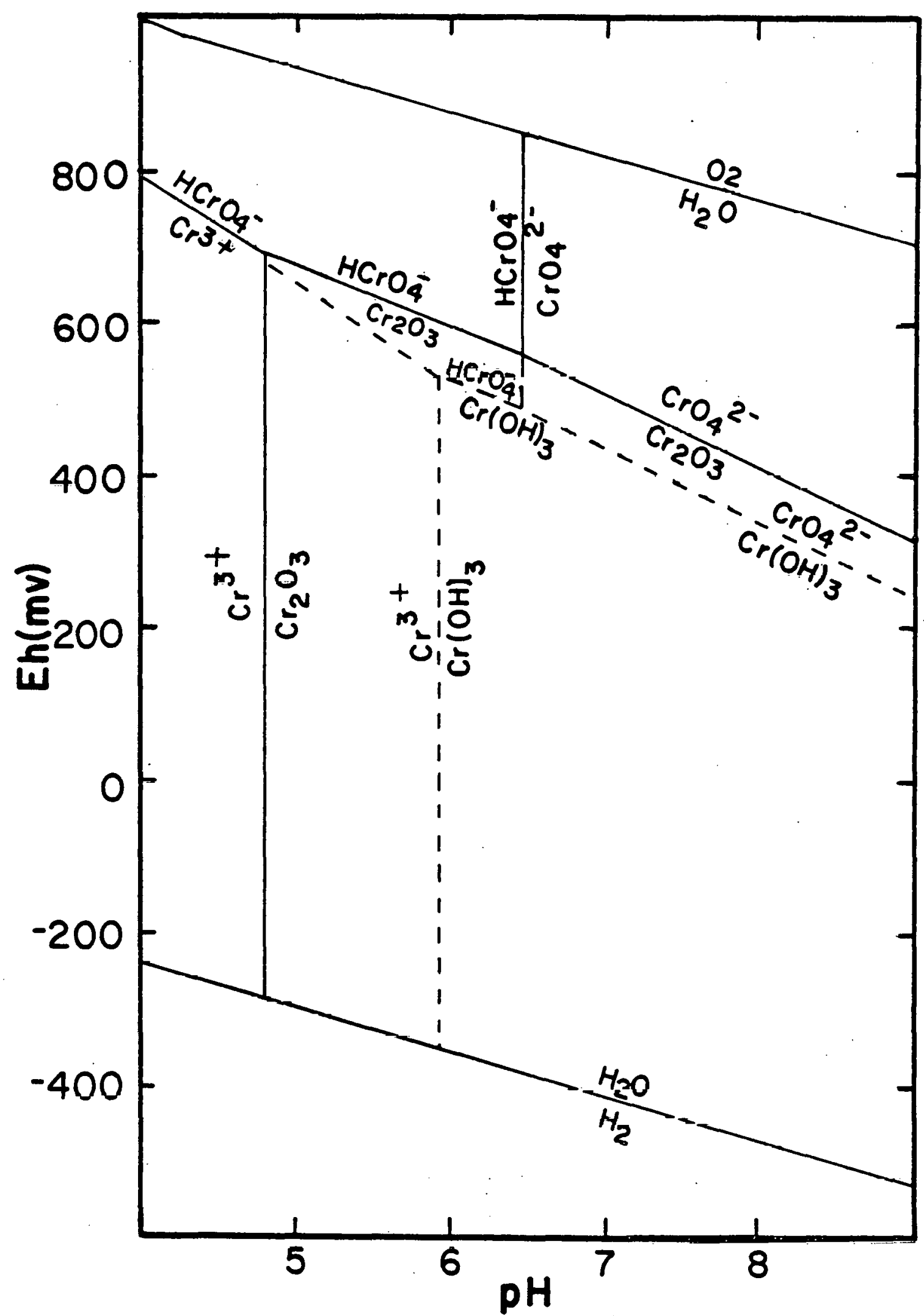

Figure 5. Stability of $\mathrm{Cr}(\mathrm{OH})_{3}$ and $\mathrm{Cr}_{2} \mathrm{O}_{3}$ in $10^{-6} \mathrm{M} \mathrm{Cr}$ at $25^{\circ} \mathrm{C}$ and 1 atm total pressure. 
metastably to $\mathrm{Cr}_{2} \mathrm{O}_{3}$. The size of the $\mathrm{Cr}(\mathrm{OH})_{3}$ stability field is less than the size of the $\mathrm{Cr}_{2} \mathrm{O}_{3}$ field under the same conditions indicating $\mathrm{Cr}(\mathrm{OH})_{3}$ is more soluble than $\mathrm{Cr}_{2} \mathrm{O}_{3}$. A soluble $\mathrm{Cr}$ concentration of $10^{-6}$ M (52 $\mu g / \ell C r)$ was chosen, since this level represents the maximum permissible concentration in drinking water (EPA, 1980). Usually, concentrations of one-tenth this level are found in natural waters (Wedepohl, 1970). At higher solution $\mathrm{Cr}$ concentrations the $\mathrm{Cr}_{2} \mathrm{O}_{3}$ field increases and at lower solution $\mathrm{Cr}$ concentrations the field decreases. At low $\mathrm{pH}$ levels $\mathrm{Cr}^{3+}$ is the most stable species over a wide range in Eh. At high $\mathrm{Eh}$ levels the hexavalent $\mathrm{HCrO}_{4}^{-}$and $\mathrm{CrO}_{4}^{2-}$ species are stable over a wide $\mathrm{pH}$ range. Thus, in moderately well oxidized soils we would expect $\operatorname{Cr}(\mathrm{VI})$ to exist.

By comparing Figures 3, 4, and 5 it can be seen that there is considerable overlapping of the stability fields of the hexavalent species of both elements. Thus, under roughly the same conditions $\mathrm{Cr}(\mathrm{VI})$ and $\mathrm{Pu}(\mathrm{VI})$ are stable. The extent of overlapping will change as equilibrium conditions change and uncertainties in the extent of overlapping are largely due to uncertaintles. in the thermodynamic data, but it does seem reasonable to assume that in many soils where $\operatorname{Cr}$ (VI) 1s stable, then Pu(VI) may be stable.

\section{Radiolytic Oxidation and $\mathrm{PuO}$ Microsphere}

\section{Dissolution Studies}

There have been a number of $\mathrm{HuU}_{2}$ microsphere dissolution studies and some of these are summarized in Table 2. The most important thing to note is that the soluble $\mathrm{Pu}$ is virtually all oxidized. The group at Oak Ridge National Laboratory (Bondietti and Reynolds, 1976; Dahlman et 1.., 1976; Bondietti and Sweeton, 1977) used coprecipitation and 
Table 2. Summary of ${ }^{239} \mathrm{PuO}_{2}$ dissolution studies.

\begin{tabular}{|c|c|c|c|c|c|c|}
\hline Solubility & Valence & Amt. ${ }_{\text {Used }}^{239} \mathrm{FuC}_{2}$ & $\begin{array}{l}\text { Equilibrating } \\
\text { Solution }\end{array}$ & $\mathrm{pH}$ & $\begin{array}{l}\text { Eçuflibration } \\
\text { Time }\end{array}$ & Reference \\
\hline$\sim 10^{-10} \mathrm{M}$ & Pu(V/VI) 95\% & -- & $10^{-4} \mathrm{M} \mathrm{NH}_{4} \mathrm{HCO}_{3}$ & 7 & 3 wks & $\begin{array}{l}\text { Bondietti and } \\
\text { Reynolds (1976) }\end{array}$ \\
\hline$\sim 10^{-9} \mathrm{Y}$ & Pu $(\mathrm{V} / \mathrm{VI}) \sim 95 \%$ & $2.2-2.7 \mathrm{mg}$ & $20 \mathrm{ml} 10^{-3} \mathrm{M} \mathrm{NaHCO}_{3}$ & 7 & 9 wks & $\begin{array}{c}\text { Dahlman et } \\
(1976)\end{array}$ \\
\hline$\sim 10^{-11} \mathrm{M}$ & $\mathrm{Pu}(\mathrm{V} / \mathrm{VI}) \sim 95 \%$ & $1.77 \mathrm{mg}$ & $20 \mathrm{ml} 10^{-3} \mathrm{M} \mathrm{NaHCO}_{3}$ & 7 & 10 wks & $\begin{array}{l}\text { Bondiett } 1 \text { and } \\
\text { Sweeton (1977) }\end{array}$ \\
\hline$\sim 10^{-6}-10^{-9} \mathrm{M}$ & $\mathrm{Pu}(\mathrm{V})$ & $8 \mathrm{mg}$ & $20 \mathrm{ml} 0.0015 \mathrm{M} \mathrm{CaCl}_{3}$ & $4-8$ & 13-36 wks & $\begin{array}{l}\text { Ra1, Serne, and } \\
\text { Moore (1980) }\end{array}$ \\
\hline
\end{tabular}

Microsphere properties:

Calcined at $1150^{\circ} \mathrm{C}$

149-174 $\mu \mathrm{m}$ diameter

$0.012 \mathrm{~m}^{2} / \mathrm{g}$ specific surface 
chelation-solvent extraction techniques to show that nearly all the solution $\mathrm{Pu}$ contacting $\mathrm{PuO}_{2}$ microspheres is $\mathrm{Pu}(\mathrm{V})$ and/or $\mathrm{Pu}(\mathrm{VI})$. Their methods did not allow them to distinguish between $\mathrm{Pu}(\mathrm{V})$ and $\mathrm{Pu}(\mathrm{VI})$. Rai, Serne, and Swanson (1980) working at Battelle Northwest Laboratorles showed indirectly that the solution species contacting $\mathrm{PuO}_{2}$ microspheres is $\mathrm{Pu}(\mathrm{V})$. They demonstrated using chelation-solvent extraction that $\mathrm{Pu}($ IV) was absent from the equilibrium solution and using spectrophotometry that $\mathrm{Pu}(V I)$ was absent.

If the solution species of $\mathrm{Pu}$ contacting $\mathrm{PuO}_{2}$ microspheres is $\mathrm{Pu}(\mathrm{V})$ and/or $\mathrm{Pu}(\mathrm{VI})$, then oxidation must have occurred during dissolution of $\mathrm{PuO}_{2}$. Oxidation of $\mathrm{Pu}(\mathrm{IV})$ by $\mathrm{O}_{2}$ is so slow it can be ignored (Cleveland, 1970; Bondietti, personal communication). Therefore, another oxidizing agent must be present. The most likely candidate is $\mathrm{H}_{2} \mathrm{O}_{2}$ produced from the radiolysis of $\mathrm{H}_{2} \mathrm{O}$ by the $\alpha$ radiation from the $\mathrm{PuO}_{2}$. The proposed mechanism of $\mathrm{PuO}_{2}$ microsphere dissolution is as follows (Bondietti and Sweeton, 1977): Alpha emission recoils with sufficient energy to break chemical bonds cause fragmentation of the oxide lattice producing colloidal $\mathrm{PuO}_{2}$ particles. This is the aggregate recoil effect. When the $\mathrm{PuO}_{2}$ microspheres are placed in solution the $\mathrm{PuO}_{2}$ colloidal particles are released to solution. This accounts for the rapid appearance of "polymeric" Pu which can be removed with an ultracentrifuge and does not extract using a chelation-solvent extraction method. These colloidal particles are more susceptible to dissolution than the microsphere. Thus, soluble $P u$ concentrations increase with time. The $\alpha$ radiation also causes the radiolysis of water with $\mathrm{H}_{2} \mathrm{O}_{2}$ produced. Hydrogen peroxide reactions with $\mathrm{Pu}$ are complex, since $\mathrm{H}_{2} \mathrm{O}_{2}$ can act as both an oxidizing and a reducing agent, but at neutral to alkaline $\mathrm{pH}$ values 
$\mathrm{H}_{2} \mathrm{O}_{2}$ will oxidize $\mathrm{Pu}(\mathrm{IV})$, thus resulting in $\mathrm{Pu}(\mathrm{V} / \mathrm{VI})$ in solution. This mechanism would account for the oxidized Pu in solution in the Oak Ridge experiments since they were run at neutral $\mathrm{pH}$, but what about the studies by Rai, Serne, and Moore (1980) where acid $\mathrm{pH}$ levels were also used and virtually all solution $\mathrm{Pu}$ was found to be $\mathrm{Pu}(\mathrm{V})$ ? A possible explanation is as follows: At acid $\mathrm{pH}$ levels the solubility of $\mathrm{PuO}_{2}$ is increased to the point where disproportionation of $\mathrm{Pu}(\mathrm{IV})$ is more likely. Dispropurtionation of $\mathrm{Pu}(\mathrm{IV})$ leads to $\mathrm{Pu}(\mathrm{III})$ and $\mathrm{Pu}(\mathrm{VI})$. The $\mathrm{Pu}($ III) could then be oxidized by $\mathrm{H}_{2} \mathrm{O}_{2}$ while the $\mathrm{Pu}(\mathrm{VI})$ is reduced resulting in net Pu(V) production. Whatever the mechanism it seems clear that the nxi:= dation is due to a radiolytic effect.

The studico by Rai, Serne, and Moure (1980) indicate a solubility of $\mathrm{PuO}_{2}$ at $\mathrm{pH} 7$ two orders of magnitude greater than the solubility determined by the Oak Ridge group, but the variation in solubility as determined by the $\mathrm{PuO}_{2}$ microsphere dissolution studies is not as great as the difference between the experimentally determined solubility (Rai, Serne, and Moore, 1980) and the solubility calculated from the Baes and Mesmer (1976) thermodynamic data (Rai and Serne, 1977).

At this point it is necessary to discuss the various discrepancies. First, there is the variability among the $\mathrm{PuO}_{2}$ dissolution studies. The group at Oak Ridge used several methods to try to carefully distinguish between solution and ultrafine colloidal $\mathrm{Pu}$. The Battelle group on the other hand was not as careful. Even though the Battelle group centrifuged their $\mathrm{PuO}_{2}$ suspensions for $40 \mathrm{~min}$ at $6000 \mathrm{~g}$ and filtered them through 0.015 jim membrane filters, ultrafine $\mathrm{Pu}($ IV) polymer may have been depolymerized and extracted during the tri-n-butyl phosphate extraction they used. This depolymerized and extracted $\mathrm{Pu}($ IV) would 
have been counted as oxidized $\mathrm{Pu}$ when in fact it was not. This would lead to a higher $\mathrm{Pu}$ solubility than that determined by the Oak Ridgegroup. The true solution $\mathrm{Pu}$ concentration concentration in the Battelle experiments may have been much. lower than the values reported and the solution species may have been $\mathrm{Pu}(\mathrm{VI})$, but was below the spectrophotometric detection limit. A careful evaluation of the reliability of the tri-n-butyl phosphate extraction method for trace solution $\mathrm{Pu}$ levels by comparison with the Oak Ridge methods is needed.

Aside from the problem of the reliability of the Battelle group data, Rai, Serne, and Moore (1980) concluded that their system was in equilibrium and that their measured redox potential was a valid Eh measurement. The fact that solution concentrations do not change over. a long period of time is by itself an insufficient test for equilibrium. In fact, the concept of equilibrium may not be entirely meaningful where radiolytic oxidation and radioactive decay are occurring. The measured redox potential was in fact a mixed potential reflecting the potentials of the $\mathrm{Pu}$ redox species and the water radiolysis products. : Even if equilibrium had existed, the measured potential may not accurately have reflected the true equilibrium Eh. A more useful experiment would be to study the dissolution of $\mathrm{PuO}_{2}$ in Eh buffers. This problem was recognized by Rai, Serne, and Moore (1980) and they are planning further experiments along this line. Until more data are available we must conclude that Rai, Serne, and Moore (1980) may be erroneous in assuming their data can be used to calculate an equilibrium constant for the dissolution of $\mathrm{PuO}_{2}$.

However, if the $\mathrm{PuO}_{2}$ microsphere dissolution study measurements are correct, there is the very large discrepancy between the experimentally 
determined solubility and the solubility calculated from the Baes and Mesmer (1976) thermodynamic data (Rai and Serne, 1977) to resolve. This difference can probably be attributed almost entirely to radiolytic effects. Radiolytic oxidation is favored by larger $\mathrm{PuO}_{2}$ particles where the radiation density. is higher, but is probably unimportant among dispersed, submicron environmental-type $\mathrm{PuO}_{2}$ (Bondietti and Sweeton, 1977). Therefore, we conclude that the solubility calculated from the $\mathrm{PuO}_{2}$ microsphere dissolution study measurements may be reliable for those cases when large $\mathrm{PuO}_{2}$ particles ( $>$ silt size) are present in the soil if the measurements actually reflcct equilibrium cundftlons, but the thermodynamically calculated solubility is probably reliable for dispersed, submicron $\mathrm{PuO}_{2}$ particles. Thus, both stability diagrams (Figures 3 and 4) may have their use. However, the $\mathrm{Pu}$ levels actually observed in contaminated waters are more in accord with the thermodynamically calculated values than the $\mathrm{PuO}_{2}$ microsphere dissolution measurements.

At the NTS most of the Pu is associated with the coarse silt-sized particles (Tamura, 1975). However, this does not necessarily mean that the $\mathrm{PuO}_{2}$ particles are coarse silt-sized, but rather smaller $\mathrm{PuO}_{2}$ particles are associated with silt-sized minerals. Plutonium also has been found occluded in glass and metal at nuclear event sites. Therefore, it is expected that radiolytic oxidation is not important in these soils except where large $\mathrm{PuO}_{2}$ particles exist. Instead of radiolytic oxidation, oxidation by manganese oxides is favored and this is examined in the next section. 
Thermodynamics of Chromium and Plutonium Oxidation

by Manganese Oxide Minerals

In Table 3 are several oxidation and reduction half-reactions involving $\mathrm{Cr}, \mathrm{Pu}$, and manganese $(\mathrm{Mn})$ together with the $\log \mathrm{K}$ values for the reactions. The $\log \mathrm{K}$ values for the $\mathrm{Pu}$ half-reactions were calculated from data taken from Rai and Serne (1977); Rai, Serne, and Moore (1980); and Rai, Serne, and Swanson (1980). The log $\mathrm{K}$ values for the Cr half-reactions were taken from Bartlett and James (1979) who calculated their $\log \mathrm{K}$ values from the data given in Garrels and Christ (1965), while the $\log \mathrm{K}$ values for the Mn half-reactions were taken from Lindsay (1979). The Cr oxidation reactions shown are for the oxidation of $\mathrm{Cr}_{2} \mathrm{O}_{3}, \mathrm{Cr}(\mathrm{OH})_{3}$, and aqueous $\mathrm{Cr}$ (III) to aqueous $\mathrm{Cr}(\mathrm{VI})$. The $\mathrm{Mn}$ reduction reactions shown are for the reduction of four common tetravalent manganese oxide minerals to aqueous $\mathrm{Mn}$ (II). The $\mathrm{Pu}$ oxidation reactions listed are for the oxidation of $\mathrm{PuO}_{2}$ to aqueous $\mathrm{PuO}_{2}^{+}$or $\mathrm{PuO}_{2} \mathrm{CO}_{3} \mathrm{OH}^{-}$.

If one of the $\mathrm{Cr}$ or $\mathrm{Pu}$ half-reactions is combined with one of the manganese oxide half-reactions and the $\log \mathrm{K}$ values for the two halfreactions are added, a net redox reaction and its equilibrium constant are obtained. By choosing appropriate reaction conditions it is possible to calculate the equilibrium concentration of soluble $\mathrm{Cr}$ or $\overline{\mathrm{P}} \mathrm{u}$ as a function of soil solution $\mathrm{pH}$ and soluble Mn(II) concentration.

As an example, consider the oxidation of $\mathrm{PuO}_{2}$ to $\mathrm{PuO}_{2} \mathrm{CO}_{3} \mathrm{OH}^{-}$by $\delta-\mathrm{MnO}_{2}$ which is the reaction being proposed as the one occurring in the NTS soils. The mineral $\delta-\mathrm{MnO}_{2}$ is a hydrated, amorphous form of manganese oxide probably found in soils as a coating over silicate mineral particles (Taylor and McKenzie, 1966; McKenzle, 1977). F1rst, the two halfreactions and their $\log \mathrm{K}$ values from Table 3 are added to obtain the 
Table 3. Oxidation or reduction half-reactions involving $\mathrm{Cr}$, $\mathrm{Mn}$, and $\mathrm{Pu}$.
Reaction
$\log \mathrm{K}_{25^{\circ} \mathrm{C}}$
$0.17 \mathrm{Cr}_{2} \mathrm{O}_{3}+0.67 \mathrm{H}_{2} \mathrm{O}=0.17 \mathrm{Cr}_{2} \mathrm{O}_{7}^{2-}+1.33 \mathrm{H}^{+}+\mathrm{e}^{-}$
$-19.7$
$0.17 \mathrm{Cr}_{2} \mathrm{O}_{3}+0.83 \mathrm{H}_{2} \mathrm{O}=0.33 \mathrm{HCrO}_{4}^{-}+1.33 \mathrm{H}^{+}+\mathrm{e}^{-}$
$-20.0$
$0.17 \mathrm{Cr}_{2} \mathrm{O}_{3}+0.83 \mathrm{H}_{2} \mathrm{O}=0.33 \mathrm{CrO}_{4}^{2-}+1.67 \mathrm{H}^{+}+\mathrm{e}^{-}$
$-22.2$
$0.33 \mathrm{Cr}(\mathrm{OH})_{3}+0.17 \mathrm{H}_{3} \mathrm{O}=0.17 \mathrm{Cr}_{2} \mathrm{O}_{7}^{2-}+1.33 \mathrm{H}^{+}+\mathrm{e}^{-}$
$-18.6$
$0.33 \mathrm{Cr}(\mathrm{OH})_{3}+0.33 \mathrm{H}_{2} \mathrm{O}=0.33 \mathrm{HCrO}_{4}^{-}+1.33 \mathrm{H}^{+}+\mathrm{e}^{-}$
$-18.9$
$0.33 \mathrm{Cr}(\mathrm{OH})_{3}+0.33 \mathrm{H}_{2} \mathrm{O}=0.33 \mathrm{CrO}_{4}^{2-}+1.67 \mathrm{H}^{+}+\mathrm{e}^{-}$
$-21.0$
$0.33 \mathrm{Cr}^{3+}+1.17 \mathrm{H}_{2} \mathrm{O}=0.17 \mathrm{Cr}_{2} \mathrm{O}_{7}^{2-}+2.33 \mathrm{H}^{+}+\mathrm{e}^{-}$
$-22.5$
$0.33 \mathrm{Cr}^{3+}+1.33 \mathrm{H}_{2} \mathrm{O}=0.33 \mathrm{HCrO}_{4}^{-}+2.33 \mathrm{H}^{+}+\mathrm{e}^{-}$
$-22.8$
$0.33 \mathrm{Cr}^{3+}+1.33 \mathrm{H}_{2} \mathrm{O}=0.33 \mathrm{CrO}_{4}^{-}+2.67 \mathrm{H}^{+}+\mathrm{e}^{-}$
$-25.0$
$0.33 \mathrm{CrO}_{2}^{-}+0.78 \mathrm{H}_{2} \mathrm{O}=0.33 \mathrm{CrO}_{4}^{2-}+1.33 \mathrm{H}^{+}+\mathrm{e}^{-}$
$-15.2$
$0.5 \mathrm{Mn}_{3} \mathrm{O}_{4}+4 \mathrm{H}^{+}+\mathrm{e}^{-}=1.5 \mathrm{Mn}^{2+}+2 \mathrm{H}_{2} \mathrm{O}$
31.5
$\mathrm{MnOOH}+3 \mathrm{H}^{+}+\mathrm{e}^{-}-\mathrm{Mn}^{2+}+2 \mathrm{H}_{2} \mathrm{O}$
25.3
$0.5 \mathrm{Mn}_{2} \mathrm{O}_{3}+3 \mathrm{H}^{+}+\mathrm{e}^{-}=\mathrm{Mn}^{2+}+1.5 \mathrm{H}_{2} \mathrm{O}$
25.7
$0.5 \mathrm{MnO}_{2}+2 \mathrm{H}^{+}+\mathrm{e}^{-}=0.5 \mathrm{Mn}^{2+}+\mathrm{H}_{2} \mathrm{O}$
22.1 
Table 3 (Continued).

Equilibrium constants calculated from data listed in Rai and Serne (1977)

$\underline{\text { Reaction }}$

$\underline{\log \mathrm{K}_{25^{\circ} \mathrm{C}}}$

$-26.0$

$\mathrm{PuO}_{2}=\mathrm{PuO}_{2}^{+}+\mathrm{e}^{-}$

$0.5 \mathrm{PuO}_{2}+0.5 \mathrm{CO}_{2}+\mathrm{H}_{2} \mathrm{O}=0.5 \mathrm{PuO}_{2} \mathrm{CO}_{3} \mathrm{OH}^{-}+1.5 \mathrm{H}^{+}+\mathrm{e}^{-}$ $-25.0$

Equilibrium constants calculated from data listed in Rai and Serne (1977); Rai, Serne, and Moore (1980); and Rai, Serne, and Swanson (1980)

$\begin{array}{lc}\mathrm{PuO}_{2}=\mathrm{PuO}_{2}^{+}+\mathrm{e}^{-} & \frac{\log \mathrm{K}_{25} \mathrm{C}}{-14.8} \\ 0.5 \mathrm{PuO}_{2}+0.5 \mathrm{CO}_{2}+\mathrm{H}_{2} \mathrm{O}=0.5 \mathrm{PuO}_{2} \mathrm{CO}_{3} \mathrm{OH}^{-}+1.5 \mathrm{~K}^{+}+\mathrm{e}^{-} & -19.7\end{array}$


net redox reaction and its $\log \mathrm{K}$ value:

$$
\begin{array}{cr}
0.5 \mathrm{MnO}_{2}+2 \mathrm{H}^{+}+\mathrm{e}^{-}=0.5 \mathrm{Mn}^{2+}+\mathrm{H}_{2} \mathrm{O} & \frac{\log \mathrm{K}}{22.1} \\
0.5 \mathrm{PuO}_{2}+0.5 \mathrm{CO}_{2}+\mathrm{H}_{2} \mathrm{O}=0.5 \mathrm{PuO}_{2} \mathrm{CO}_{3} \mathrm{OH}^{-}+1.5 \mathrm{H}^{+}+\mathrm{e}^{-} & -25.0 \\
0.5 \mathrm{MnO}_{2}+0.5 \mathrm{PuO}_{2}+0.5 \mathrm{CO}_{2}+0.5 \mathrm{H}^{+}= & -2.9 \\
0.5 \mathrm{Mn}^{2+}+0.5 \mathrm{PuO}_{2} \mathrm{CO}_{3} \mathrm{OH}^{-} &
\end{array}
$$

The equilibrium constant expression for this reaction is given by:

$$
\mathrm{pK}=\mathrm{pMn}^{2+}+\mathrm{pPuO}_{2} \mathrm{CO}_{3} \mathrm{OH}^{-}-\mathrm{pCO}_{2}-\mathrm{pH}=5.8
$$

Solving for $\mathrm{pPuO}_{2} \mathrm{CO}_{3} \mathrm{OH}^{-}$leads to:

$\mathrm{pPuO}_{2} \mathrm{CO}_{3} \mathrm{OH}^{-}=\mathrm{pH}+\mathrm{pCO}_{2}-\mathrm{pMn}^{2+}+5.8$

Thus, the solution concentration of $\mathrm{PuO}_{2} \mathrm{CO}_{3} \mathrm{OH}^{-}$can be calculated as a function of $\mathrm{pH}, \mathrm{CO}_{2}$ pressure, and $\mathrm{Mn}(\mathrm{II})$ concentration.

This has been dune for four levels of $\mathrm{Mn}(\mathrm{IL})$, a $\mathrm{CU}_{2}$ pressure of $10^{-3.5}$ atm, and over an environmentally meaningful range of $\mathrm{pH}$ values and the results are presented in Figure 6 . The $\mathrm{CO}_{2}$ pressure chosen represents the atmospheric $\mathrm{CO}_{2}$ level. Increasing solubility of $\mathrm{PuO}_{2}$ is favored as the dissolved carbonate concentration increases or as $\mathrm{PCO}_{2}$ increases. The four $M(I I)$ concentrations chosen represent a range of levels likely to occur in soil solution. Each line on the graph represents the equilibrium concentration of $\mathrm{Pun}_{2} \mathrm{Cn}_{\mathrm{j}^{\circ}} \mathrm{OH}^{-}$as a function of $\mathrm{pH}$ for a given level of dissolved $\mathrm{Mn}$ (II), and $\mathrm{pPuO}_{2} \mathrm{CO}_{3} \mathrm{OH}^{-}$and $\mathrm{pH}$ values below a line indicate that the solution is undersaturated with respect to $\mathrm{PuO}_{2}$, so the reaction is thermodynamicaliy spontaneous in the direction of oxidized $\mathrm{Pu}$. At the $\mathrm{pH}$ levels found in the NTS soils significant 


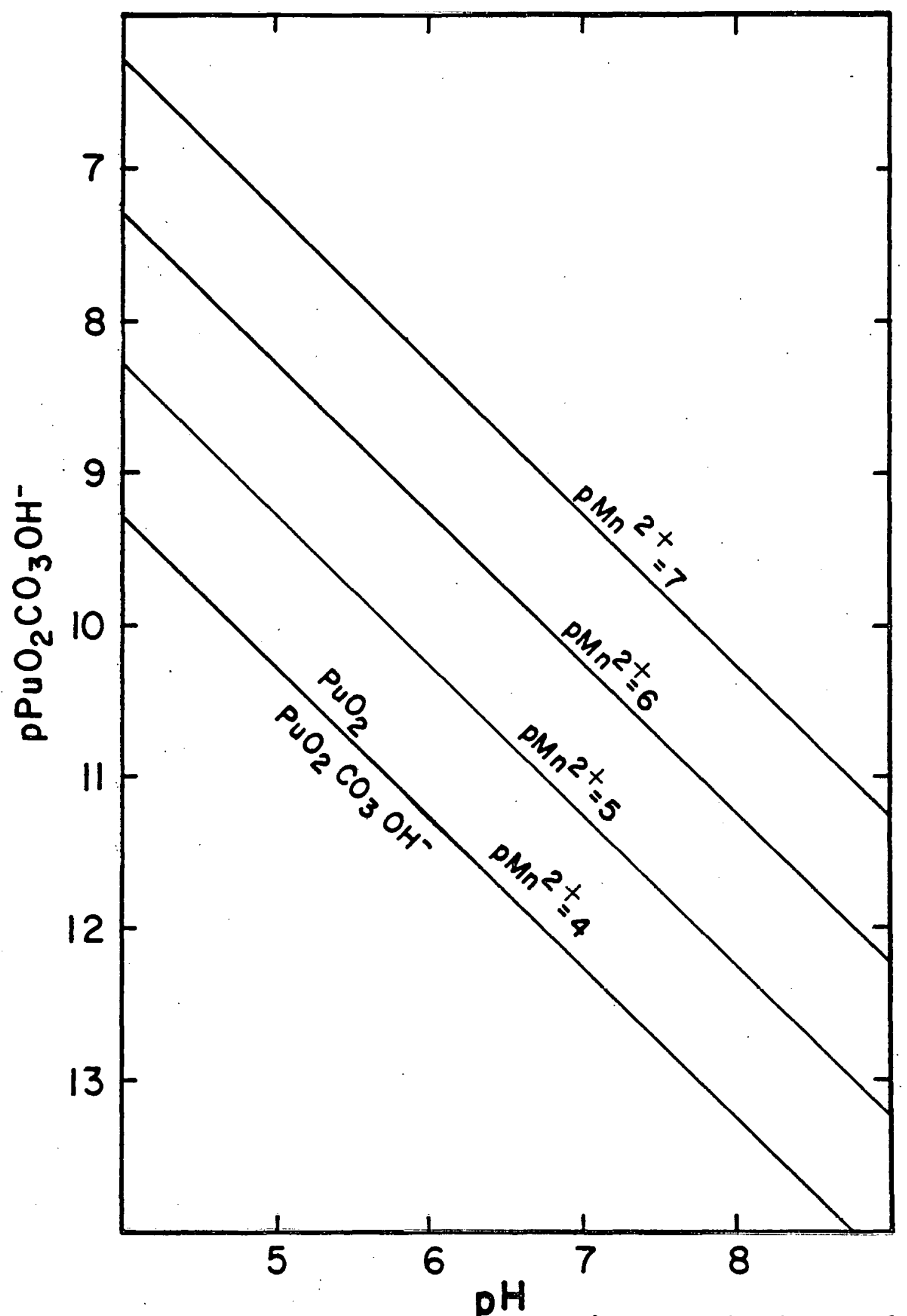

Figure 6. Solubility of $\mathrm{PuO}_{2}$ as controlied by $\delta-\mathrm{MnO}_{2}$ in the absence of reducing agents at $25^{\circ} \mathrm{C}, 10^{-3.5}$ atm $\mathrm{CO}_{2}$, and 1 atm total pressure dssuming radiolytic oxidation is not occurring. 
levels of dissolved Pu are favored by very low dissolved $\mathrm{Mn}$ (II) concentrations if $\delta-\mathrm{MnO}_{2}$ is controlling $\mathrm{PuO}_{2}$ weathering.

Figure 6 was constructed from the thermodynamic data listed in Rai and Serne (1977), and so is applicable to dispersed, submicron $\mathrm{PuO}_{2}$ particles where radiolytic oxidation is unimportant. For larger $\mathrm{PuO}_{2}$ particles where radiolytic oxidation occurs, even greater solubility of $\mathrm{PuO}_{2}$ can be observed when $\delta-\mathrm{MnO}_{2}$ controls the solution Eh. This situation is observed in Figure 7. The data of Rai, Serne, and Moore (1980) indicate that $\mathrm{PuO}_{2}$ has a solubility of $10^{-6}$ to $10^{-9} \mathrm{M}$ in the $\mathrm{pH}$ range of 1 to 8 when radiolytic uxldation is occurring provided their data are reliable. The Eh of the solution is poised by the radiolytic oxidation of $\mathrm{PuO}_{2}$, since no other oxidizing agents are present other than the products of water radiolysis. When $\delta-\mathrm{MnO}_{2}$ is added to the solution a higher solution Eh is set by the $\delta-\mathrm{MnO}_{2}$ equilibrium and much higher levels of soluble $\mathrm{Pu}$ could be observed as Figure 7 indicates. However, F1gure 7 is invalid if the equilibrium constant calculated from the Rai, Serne, and Mnnre (1980) data io crroneous due Lu nun-equ1librium conditions. Thus, we conclude that $\mathrm{PuO}_{2}$ is highly unstable in the presence of $\delta-\mathrm{MnO}_{2}$ and is especially so at larger particle sizes where radinlytic. oxidation and oxidation by $\delta-\mathrm{MnO}_{2}$ combine to diccolve the $\mathrm{PuO}_{2}$.

The above analysis assumes that $\delta-\mathrm{MnO}_{2}$ is in control of the soil solution Eh and in the microenvironment surrounding the $\mathrm{MnO}_{2}$ mineral this is the case. Even though the overall redox status of a soil might be controlled by the most abundant redox components in the soil (iron species and organic matter), wicroreg1ons or zones of oxidation and/or reduction can occur where the redox status is controlled by a soil component that dominates the localized region (Bartlett, 1981). This is 


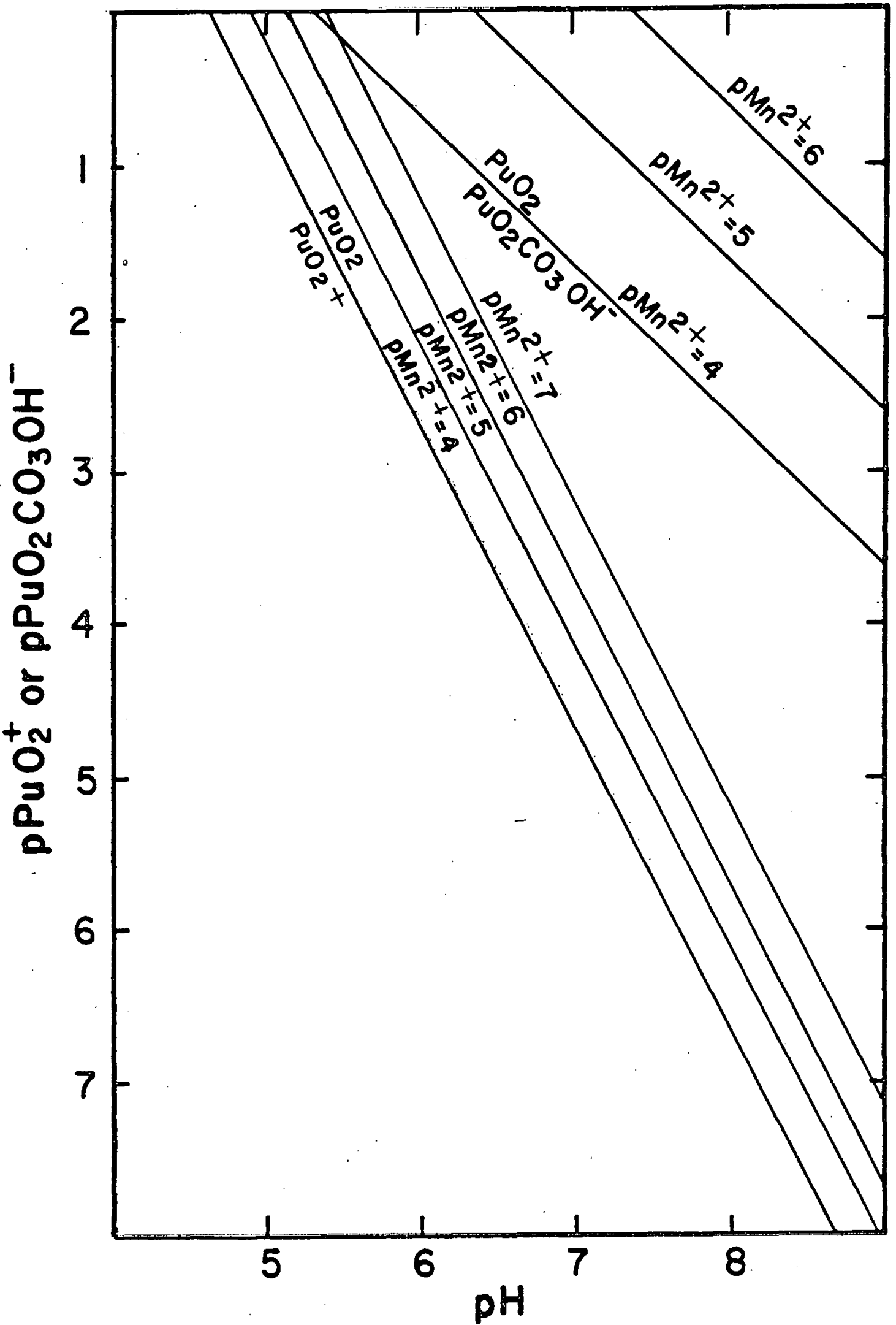

Figure 7. Solubility of $\mathrm{PuO}_{2}$ as controlled by $\delta-\mathrm{MnO}_{2}$ in the absence of reducing agents at $25^{\circ} \mathrm{C}, 10^{-3.5}$ atm $\mathrm{CO}_{2}$, and 1 atm total pressure assuming radiolytic oxidation is occurring. 
why $\mathrm{Cr}$ can be oxidized in soil even though manganese oxide is usually much less abundant in soils $(<0.2 \%)$ than is organic matter $(0.5-4 \%)$. However, outside the $\mathrm{MnO}_{2}$ microenvironment organic matter and minerals containing $\mathrm{Fe}^{2+}$ ions probably control the Pu redox chemistry. These soil components would keep $\mathrm{Pu}$ in a reduced state, thus severely restricting its mobility. Bondietti et al. (1975) showed that fulvic acid and root exudate components (polygalacturonic and alginic acids) readily reduce Pu. Recently, researchers at Oak Ridge National Laboratory have demonstrated that the $\mathrm{Fe}^{2+}$ ions in ferromagnesian minerals will reduce. Pu (Tamura, personal communication). Because of the widespread occurrence of $\mathrm{Fe}^{2+}$ and organic matter in soils it would be expected that $\mathrm{Pu}$ would remain in a reduced state in most soil environments, and indeed this seems to be the case most of the time. However, most of the iron in NTS soils would be Fe(III) and these soils are likely low in organic matter so the above situation may not be applirahle to NTS soils. Sorption reactions also restrict the amount of solution Pu available, so that predicted levels are piubduly never achleved which is a tortunate situation considering the toxicity of the element. Thus, the levels of soluble $\mathrm{Pu}$ actually found are dictated by the rates of reartinn with the various soil components.

It is also possible to illustrate the control $\delta-\mathrm{MnO}_{2}$ has over the sulubll1ty of a $\mathrm{Cr}$ compound and this has been done for $\mathrm{Cr}(\mathrm{OH})_{3}$ and is shown in Figure 8. This diagram illustrates that $\mathrm{Cr}(\mathrm{OH})_{3}$ is extremely unstable in the presence of $\delta-\mathrm{MnO}_{2}$, since the equilibrium occurs at $\mathrm{pH}$ levels well above those of normal soils. The diagram predicts that quite high levels of soluble, oxidized $\mathrm{Cr}$ could be produced as a result of the action of soil manganese oxides on $\mathrm{Cr}(\mathrm{OH})_{3}$. However, the 


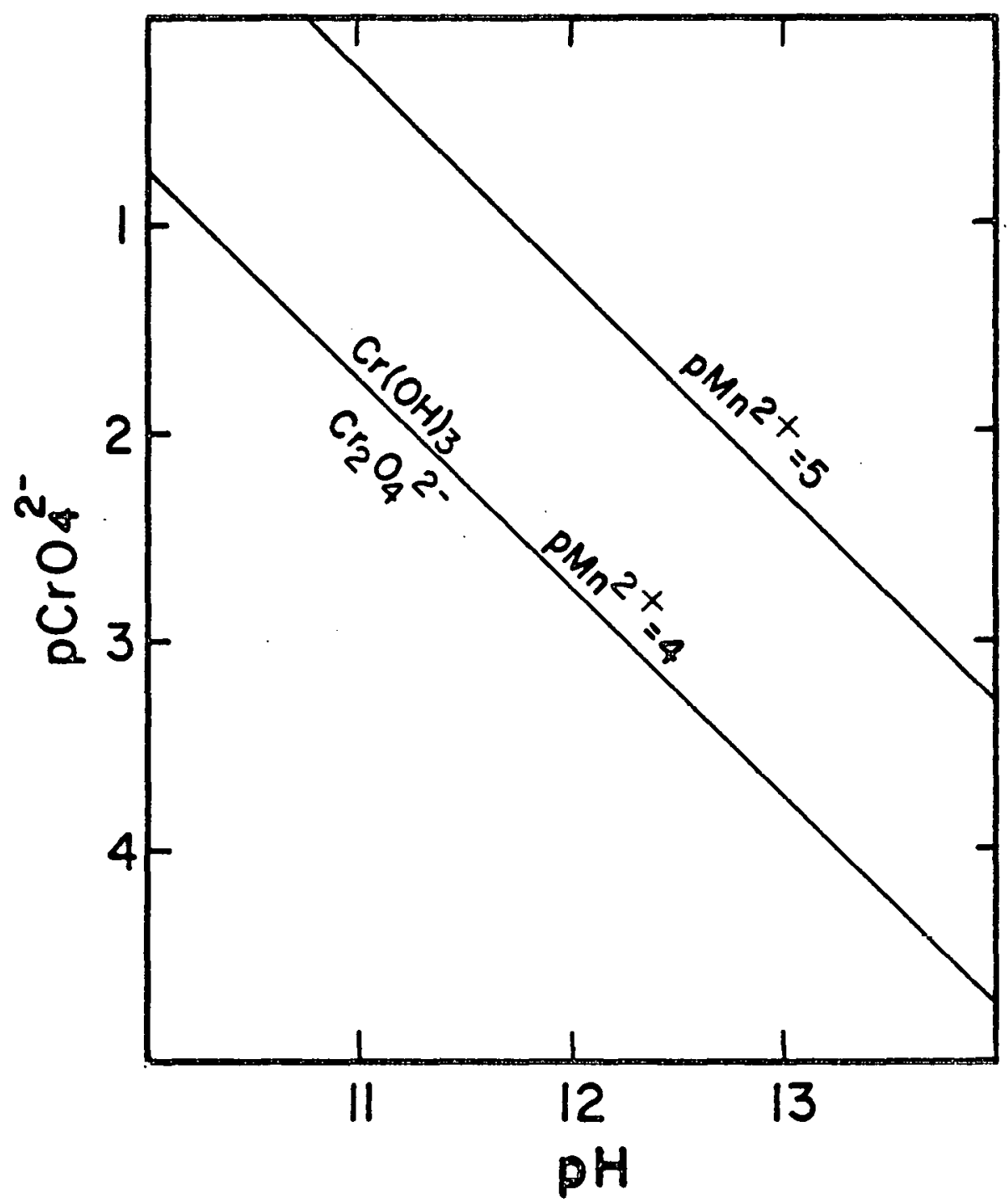

Figure 8. Solubility of $\mathrm{Cr}(\mathrm{OH})_{3}$ as controlled by $\delta-\mathrm{MnO}_{2}$ in the absence of reducing agents at $25^{\circ} \mathrm{C}$ and 1 atm total pressure. 
presence of reducing agents and soil components which sorb $\mathrm{Cr}$ will limit the element's mobility. Also, it must be remembered that the diagrams in this section all depend upon thermodynamlc considerations which tell what is possible and not the rate of the reactions.

\section{Additional Evidence for the Oxidation}

of Plutonium by Manganese Oxide

\section{Minerals in Soil Environments}

Besides the thermodynamic evidence there is additional direct and indirect experimental evidence to support the possibility of $\mathrm{Pu}$ oxidation by manganese oxides under certain conditions.

Cleveland (1970) has summarized the important redox reactions involving $\mathrm{Pu}$ and reports that $\mathrm{Pu}(\mathrm{IV})$. is oxidized to $\mathrm{Pu}(\mathrm{VI})$ by $\mathrm{MnO}_{2}$ in the laboratory. The reaction is $90 \%$ complete in one hour using a batch rechnique and complete in 15 minutes using a column. Thus, the reaction is very faot on a geological Llute scale of huindreds to thousands of years.

Bondietti and Reynolds (1976) found that seepage water from a radioactive solid waste burial site contained ${ }^{238} \mathrm{Pu}$ that was mostly $\mathrm{Pu}(\mathrm{V} / \mathrm{VI})$. Although the original chemical form of $\mathrm{Pu}$ in the burial site Is unknown, it was postulated that it could be $\mathrm{Pu}($ IV) in which case oxidation would have occurred in order to produce $\mathrm{Pu}(\mathrm{V} / \mathrm{VI})$ in the seepage water. Since the isotope was ${ }^{238} \mathrm{Pu}$ and ${ }^{238} \mathrm{Pu}$ has, a higher radiation density than ${ }^{239} \mathrm{Pu}$, radiolytic oxidation is favored more with ${ }^{238} \mathrm{Pu}$ than w1th ${ }^{239} \mathrm{Pu}$ (Bondietti and Sweeton, 1977). The specific activity, average $\alpha$-decay energy, and energy release rate of ${ }^{238}$ Pu are $17.4 \mu \mathrm{Ci} / \mathrm{g}, 5.49 \mathrm{MEV}$, and $2.1 \times 10^{14} \mathrm{EV} / \mathrm{min}$, respectively, compared to values of $0.06 \mu \mathrm{Ci} / \mathrm{g}, 5.10 \mathrm{MEV}$, and $6.9 \times 10^{11} \mathrm{EV} / \mathrm{min}$ for ${ }^{239} \mathrm{Pu}$. However, 
it is also possible that manganese oxide coatings on soil particles at the burial site and on sediments in the seepage water could have caused the oxidation of the buried $\mathrm{Pu}$. The important fact is that $\mathrm{Pu}(\mathrm{V} / \mathrm{VI})$ has been observed in natural waters.

Bondietti and Reynolds (1976) also found that when the clay fraction of Miami silt loam was treated to remove organic matter and a ${ }^{238} \mathrm{Pu}$ solution with all of the Pu initially in the quadrivalent state was added to yield a $\mathrm{Pu}$ concentration of $0.6 \mathrm{ppm}$ in the clay, a significant fraction of $\mathrm{Pu}$ remained in solution over a long period of time rather than being sorbed. After three weeks only $50 \%$ of the added Pu had been sorbed by the treated clay compared to $99.9 \%$ by untreated clay, after eighteen weeks $61.5 \%$ had been sorbed by the treated clay compared to $99.8 \%$ by the untreated clay, and after fifty-two weeks $99.8 \%$ of the added Pu had finally been sorbed by the treated clay compared to $99.9 \%$ by the untreated clay. Of the $\mathrm{Pu}$ remaining in solution in contact with the treated clay about half was $\mathrm{Pu}(\mathrm{V} / \mathrm{VI})$. No oxidized $\mathrm{Pu}$ could be found in the solution in contact with the untreated clay.

It seems clear that the soil organic matter kept $\mathrm{Pu}$ in a reduced. state and thus strongly sorbed to the clay, but when the organic matter was removed more soluble, oxidized Pu appeared. Bondietti and Reynolds (1976) ascribed the appearance of oxidized $\mathrm{Pu}$ to a disproportionation or auto-oxidation reaction, but it is possible that any manganese oxides in the soil clay could have oxidized the added $\mathrm{Pu}$, especially since the experiment was carried out at $\mathrm{pH} 4$ where oxidation is favored.

It is interesting to note that when the free iron oxides were also removed from the soil clay, $99.8 \%$ of the added $\mathrm{Pu}$ was sorbed by the clay minus organic matter and free iron oxides. The dithionite-citrate- 
bicarbonate of Mehra and Jackson (1960) method used to remove free iron oxides, also removes manganese oxides as well. Thus, it is not sur-. prising that $\mathrm{Pu}$ initially in the quadrivalent state remained in that state and was strongly sorbed to the clay with the iron and manganese oxide coatings removed, especially if any $F e(I I)$ was present which was quite likely since the dithionite reduces iron and traces of $\mathrm{Fe}$ (II) could have remained in the soil.

\section{Hypothesis and Objectives}

Consideration of both the thermodynamic and experimental evidence for tha orridation of $\mathrm{Pu}$ by suil manyanese oxldes led to the following hypothesis: under high Eh conditions, high $\mathrm{HCO}_{3}^{-}$levels, low organic matter levels, and negligible $\mathrm{Fe}(\mathrm{II})$ levels, $\mathrm{PuO}_{2}$ particles can be oxidized to the mobile $\mathrm{PuO}_{2} \mathrm{CO}_{3} \mathrm{OH}^{-}$species by manganese oxide minerals in a soil profile. The conditions necessary for this oxidation reaction to occur were postulated to exist within soil profiles at the NTS.

Therefore, one of the main objectives of this thesis was to study the redox chemistry of $\mathrm{Pu}$ in selected soil samples from the NTS. The study was carried out in two parts which were:

1) To measure oxidized Pu in selected NTS soil samples or at Least establish as fact that oxidized $\mathrm{Pu}$ could be readily produced in such soils; and

2) To determine the amount of $\mathrm{Pu}$ associated with various soil components that may control the redox chemistry of $\mathrm{Pu}$.

This information may eventually be used to deduce the relationships between soil and solution Pu species in order to predict the dispersion and bioavailability of this element. In addition since americium (Am) is also found in NTS soils, some chemical fractionation of soil Am data 
were also obtained for possible future use.

The other main hypothesis in this thesis was that the redox chemistry of $\mathrm{Cr}$ in soil is sufficiently similar to that of $\mathrm{Pu}$ so that $\mathrm{Cr}$ reactions in soil could be used as a model for $\mathrm{Pu}$ reactions in soil. Therefore, the other main objective of the thesis was to study $\mathrm{Cr}$ reactions in soils in order to provide information to develop a general model for $\mathrm{Pu}$ reactions in soils. The experimental studies included:

1) Fractionation of soil $\mathrm{Cr}$ by selective extraction techniques in order to determine the fate of $\mathrm{Cr}$ from organic sources applied to soil;

2) Determinations of the rate and amount of $\mathrm{Cr}$ oxidation in soils and by various manganese oxide minerals as affected by the amount and source of $\mathrm{Cr}$ added and the reaction conditions; and

3) Determinations of the rate of $\mathrm{Cr}$ reduction in soil and by fulvic acid from soil and leather dust.

It is not expected that these studies would provide enough information to satisfactorily test the hypothesis: Cr reactions in soil can be used as a model for $\mathrm{Pu}$ reactions in soil. The goal was to provide basic information about $\mathrm{Cr}$ reactions in soil that might be the foundation for future studies with soil $\mathrm{Pu}$. The ultimate goal of studies such as these is a mathematical model that will accurately predict the dispersion of multiple oxidation state elements in the environment. 
MATERIALS AND METHODS

\section{Plutonium Experiments}

\section{Soil Sample Collection}

Fourteen soil samples were collected from Areas 11A, 11B, 11C, and 11D of the NTS on January 30, 1980. Area 11 is where both nuclear and safety-shot events occurred. Safety shots were detonations of nuclear devices by conventional explosions in order to test the safety of the devices. These tests resulted in the dispersion of $\mathrm{PuO}_{2}$ throughout the area. Area 11 is also where abnormal Pu distributions in the soil profile have been observed (Essington et al., 1976).

In each area sampled, samples were taken from open areas free from vegetation known as desert pavement and from underneath bushes around the perimeters of the open areas. The soil underneath the bushes was mounded up due to wind erosion and the activity of burrowing animals. Therefore, such areas are called desert mounds. In each area sampled, sufficient soil was taken from the top $2 \mathrm{~cm}$ of soil profile to fill a one-liter, wide-mouth, plastic bottle. All the soil samples were moist at the time of collection due to recent rains in the area.

\section{Chemical Fractionation of Soil $\mathrm{Pu}$ and Am}

All fourteen samples collected were surveyed by Reynolds Electrical and Engineering Company for radioactive sontaminatinn by sounting the yamma radiaclon from each sample using a Ge(Li) detector. The results of this survey are presented in Table 4. Only two of the fourteen samples collected had detectable levels of $\mathrm{Pu}$ which reflects the variable $\mathrm{Pu}$ distribution common to test site areas. One of these two samples (sample no. 60346 from Area 11C) was selected for further study. This 
Table 4. Radioactive contamination survey of fourteen soil samples collected from Areas 11A, 11B, 11C, and 11D of the NTS.

\begin{tabular}{|c|c|c|c|c|c|}
\hline $\begin{array}{c}\text { Sample } \\
\text { no. }\end{array}$ & Area Sampled & $\begin{array}{l}\text { Sample } \\
\text { Weight }\end{array}$ & ${ }^{239} \mathrm{Pu}$ & ${ }^{241} \mathrm{Am}$ & ${ }^{137} \mathrm{Cs}$ \\
\hline & & $g$ & \multicolumn{3}{|c|}{$-----n C i / g \pm \%$ error------- } \\
\hline 60339 & $11 \mathrm{~A}$ desert pavement & 721 & ND* & $\mathrm{ND}$ & ND \\
\hline 60340 & IIA desert mound & 527 & $\mathrm{ND}$ & $\mathrm{ND}$ & ND \\
\hline 60341 & $11 B$ desert pavement & 651 & ND & $\begin{array}{c}25.3 \\
( \pm 6.5)\end{array}$ & ND \\
\hline 60342 & 11B desert pavement & 737 & $\mathrm{ND}$ & $\begin{array}{c}57.6 \\
( \pm 6.3)\end{array}$ & $\begin{array}{l}0.00114 \\
( \pm 67.2)\end{array}$ \\
\hline 60343 & $11 \mathrm{~B}$ desert mound & 454 & ND & $\begin{array}{r}6.26 \\
( \pm 7.0)\end{array}$ & $\mathrm{ND}$ \\
\hline 60344 & $11 B$ desert mound & 533 & ND & $\begin{array}{r}0.76 \\
( \pm 9.0)\end{array}$ & $\mathrm{ND}$ \\
\hline 60345 & 11C desert pavement & 923 & ND & $\begin{array}{c}37.8 \\
( \pm 6.3)\end{array}$ & $\begin{array}{l}0.00382 \\
( \pm 31.7)\end{array}$ \\
\hline 60346 & $11 \mathrm{C}$ desert pavement & 735 & $\begin{array}{c}751 \\
( \pm 19.1)\end{array}$ & $\begin{array}{c}94.8 \\
( \pm 6.2)\end{array}$ & ND \\
\hline 60347 & $11 \mathrm{C}$ desert mound & 592 & ND & $\begin{array}{c}23.0 \\
( \pm 6.5)\end{array}$ & ND \\
\hline 60348 & $11 \mathrm{C}$ desert mound & 623 & ND & $\begin{array}{r}7.13 \\
( \pm 7.0)\end{array}$ & ND \\
\hline 60349 & 11D desert paventint & 796 & $\begin{array}{c}266 \\
( \pm 36.4)\end{array}$ & $\begin{array}{c}31.9 \\
( \pm 6.4)\end{array}$ & $\begin{array}{l}0.0418 \\
( \pm 13.3)\end{array}$ \\
\hline 60350 & I1D desert pavement & 680 & ND & $\begin{array}{c}5.28 \\
( \pm 7.1)\end{array}$ & $\begin{array}{l}0.0261 \\
( \pm 14.0)\end{array}$ \\
\hline 60351 & 11D desert mound & 662 & ND & $\begin{array}{c}43.6 \\
( \pm 6.4)\end{array}$ & $\begin{array}{l}0.0137 \\
( \pm 16.7)\end{array}$ \\
\hline 60352 & IID desert mound & 661 & ND & ND & \\
\hline
\end{tabular}

*None detected 
sample was extracted with $0.01 \mathrm{M} \mathrm{KH}_{2} \mathrm{PO}_{4}, 0.2 \mathrm{M} \mathrm{Na}_{2} \mathrm{CO}_{3}, 0.1 \mathrm{M} \mathrm{Na}_{4} \mathrm{P}_{2} \mathrm{O}_{7}$, $0.1 \mathrm{M} \mathrm{Na}_{2} \mathrm{CO}_{3}+0.05 \mathrm{M} \mathrm{Na}_{4} \mathrm{P}_{2} \mathrm{O}_{7}, 5.25 \% \mathrm{NaOCl}, 10 \% \mathrm{H}_{2} \mathrm{O}_{2}, 0.1 \mathrm{M} \mathrm{NH}_{2} \mathrm{OH} \cdot \mathrm{HCl}$, and dithionate-citrate-bicarbonate ( $D C B)$. These reagents were designed to extract various fractions of the soil (readily soluble ions, organic matter, and $\mathrm{Fe}$ and $\mathrm{Mn}$ oxides), and therefore various forms of $\mathrm{Pu}$ in the soil as discussed in the next chapter.

The extractions with $\mathrm{KH}_{2} \mathrm{PO}_{4}, \mathrm{Na}_{2} \mathrm{CO}_{3}, \mathrm{Na}_{4} \mathrm{P}_{2} \mathrm{O}_{7}$, and $\mathrm{Na}_{2} \mathrm{CO}_{3}+\mathrm{Na}_{4} \mathrm{P}_{2} \mathrm{O}_{7}$ were carried out as follows. Duplicate $2.5-\mathrm{cm}^{3}$ subsamples of moist soil. from Area $11 \mathrm{C}$ were added to $15-\mathrm{ml}$ plastic centrifuge tubes and $5.0 \mathrm{ml}$ of extracting solution were added to each tube, followed by mixing on a vortex mixer. The samples were allowed to sit for one hour with periodic mixing. At the end of the one-hour period the samples were centrifuged for $5 \mathrm{~min}$ at $2852^{\prime} \mathrm{g}$ and the supernatants decanted for analysis. An additional $\mathrm{Na}_{2} \mathrm{CO}_{3}$ extraction was performed on a fresh sample using an extraction time of 5 min instead of one hour. To determine Pu(III) and $\mathrm{Pu}$ (IV) in the samples the TTA-xylene and $\mathrm{PrF}_{3}-\mathrm{TTA}-x y$ lene methods as outlined below were used. To determine $\mathrm{Pu}(\mathrm{V})$ and $\mathrm{Pu}(\mathrm{VI})$ the Ca(NO $\left.{ }_{3}\right)_{2}^{-}$ hexōne and $\mathrm{NH}_{2} \mathrm{UH} \cdot \mathrm{HCL}-\mathrm{PrF}_{3}-\mathrm{ITA}-\mathrm{xy}$ lene methods were used as outlined in a later section.

The NaOCl extraction which was a modified version of the method given by Anderson (1963) was run according to the following procedure. Duplicate $2.5-\mathrm{cm}^{3}$ subsamples of moist soil were added to $15-\mathrm{ml}$ plastic centrifuge cubco. Five ml of $5.25 \%$ NaUCl adjusted to pH 9.5 with $6 \mathrm{M}$ HCl before use were added to the samples. The samples were mixed on a vortex mixer and placed in a sand bath at $100^{\circ} \mathrm{C}$ for $30 \mathrm{~min}$. The samples were centrifuged for 2 min at $2852 \mathrm{~g}$ and decanted into $25-\mathrm{m} 1$ volumetric flasks. The extraction steps were repeated four more times and the 
flasks were filled to volume with deionized water. The concentrations of the various $\mathrm{Pu}$ valence state species were determined using the methods outlined in a later section.

The $\mathrm{H}_{2} \mathrm{O}_{2}$ and $\mathrm{NH}_{2} \mathrm{OH} \cdot \mathrm{HCl}$ extractions which were modifications of methods originally given by Taylor and McKenzie (1966) and Chao (1972) were carried out as outlined below. Duplicate $2.5-\mathrm{cm}^{3}$ subsamples of moist soil were added to $15-\mathrm{ml}$ plastic centrifuge tubes and $5 \mathrm{ml}$ of extracting solution were added followed by mixing on a vortex mixer. For the $\mathrm{H}_{2} \mathrm{O}_{2}$ extraction, $10 \% \mathrm{H}_{2} \mathrm{O}_{2}$ was adjusted to $\mathrm{pH} 7$ with $1 \mathrm{M} \mathrm{NaOH}$ before use and for the $\mathrm{NH}_{2} \mathrm{OH} \cdot \mathrm{HCl}$ extraction, $0.1 \mathrm{M} \mathrm{NH}_{2} \mathrm{OH} \cdot \mathrm{HCl}$ was adjusted to $\mathrm{pH} 2$ with $6 \mathrm{MHCl}$ before use. The samples were allowed to stand overnight followed by centrifuging for $2 \mathrm{~min}$ at $2852 \mathrm{~g}$ and decanting the supernatants into $25-m l$ volumetric flasks. The extraction steps were repeated four more times and the flasks were filled to volume with deionized water. The concentrations of the various $\mathrm{Pu}$ valence state species were determined using the methods outlined in a later section.

The DCB extraction based on the method of Mehra and Jackson (1960) was carried out as follows. A citrate buffer was prepared by dissolving $226.0 \mathrm{~g}$ of sodium c1trate, $25.0 \mathrm{~g}$ of sodium bicarbonate, and $210.0 \mathrm{~g}$ of sodium chloride in 2.5 l of deionized water. The $\mathrm{pH}$ of the solution was adjusted to 7.3 with $1 \mathrm{M} \mathrm{NaOH}$ and diluted to $3 \mathrm{l}$. Duplicate $2.5-\mathrm{cm}^{3}$ subsamples of moist soil were added to 15-ml plastic centrifuge tubes followed by $2.5 \mathrm{ml}$ of deionized water and $2.5 \mathrm{ml}$ of citrate buffer. The samples were mixed on a vortex mixer and placed in a sand bath at $80^{\circ} \mathrm{C}$. After 10 min $\sim 0.1 \mathrm{~g}$ of sodium dithionite was added to each tube, the tubes were mixed and returned to the sand bath for $15 \mathrm{~min}$. The samples 
were then centrifuged for 2 min at $2852 \mathrm{~g}$ and the supernatants were decanted into $25-\mathrm{ml}$ volumetric flasks. The extraction steps were repeated twice more with the dithionite omitted for the last extraction. The flasks were filled to volume with deionized water and the concentrations of the various $\mathrm{Pu}$ species were determined using the methods outlined below.

\section{Oxidation of Carbonate-Soluble Pu}

To determine the amount of $\mathrm{Pu}$ in the soil dissolved by $\mathrm{Na}_{2} \mathrm{CO}_{3}$ and potentially oxidizable by excess $\delta-\mathrm{MnO}_{2}$, the following experiment was run: Duplicate 2.5-cm ${ }^{3}$ subsamples of soll were added to $1 b-m \perp$ plastic centrifuge tubes. One hundred milligrams of $\delta-\mathrm{MnO}_{2}$ prepared as described in a later section were added to each tube followed by $1 \mathrm{ml}$ of deionized water. The tubes were mixed on a vortex mixer and allowed to sit for three days. A $5.0 \mathrm{ml}$ aliquot of $0.2 \mathrm{M} \mathrm{Na}_{2} \mathrm{CO}_{3}$ was added to each tube. The tubes were mixed on a vortex mixer and allowed to stand for one hour with periodic mixing. The tubes were then centrifuged for 5 min at 2852 $g$ and the supernatants decanted for analysis. The Pu(III) and Pu(IV) species were extracted using the $\operatorname{PrF}_{3}-\mathrm{TTA}-\mathrm{xylene}$ procedure as outlined below. The $\mathrm{Pu}(\mathrm{V})$ and $\mathrm{Pu}(\mathrm{VI})$ species were extracted using the $\mathrm{NH}_{2} \mathrm{OH} \cdot \mathrm{HCl}-$ PrF $_{3}$-TTA-xylene procedure outlined below.

\section{Pu Valence State Separation Methods}

Tu separate Pu(III) and/or Pu(IV) from the various extracts, the TTA-xylene and/or $\operatorname{PrF}_{3}$-TTA-xylene methods were used (Bondietti and Reynolds, 1976). The TTA-xylene method was specific for $P_{11}(\mathrm{TV})$ and depended on chelating the Pu(IV) with TTA (thenoyl trifluroacetone) and extracting the Pu(IV)-TTA complex from the aqueous phase with xylene. 
The $\mathrm{PrF}_{3}$-TTA-xylene method consisted of removing $\mathrm{Pu}$ (III) and $\mathrm{Pu}(\mathrm{IV})$ from solution by coprecipitation with $\mathrm{PrF}_{3}$ and dissolving the precipitate and oxidizing the $\mathrm{Pu}($ III) to $\mathrm{Pu}(\mathrm{IV})$ prior to the TTA-xylene extraction.

The TTA-xylene method consisted of the following steps. A $1.0 \mathrm{ml}$ aliquot of sample was pipeted into a 1-dram vial. The sample was acidified to $1 \mathrm{M}$ in $\mathrm{HNO}_{3}$ by adding $60 \mu \mathrm{hl}$ of conc. $\mathrm{HNO}_{3}$. One ml of $0.5 \mathrm{M}$ TTA in o-xylene was added to the sample followed by shaking for $10 \mathrm{~min}$ on a Thomas-Boerner oscillating shaker. After the phases separated, the xylene phase was withdrawn using a transfer pipet and added to another 1-dram vial. A $0.5 \mathrm{ml}$ aliquot of $0.5 \mathrm{M}$ TTA in xylene was added to the aqueous sample, followed by shaking for $5 \mathrm{~min}$, withdrawing the organic phase, and combining it with the previously separated xylene phase. The combined xylene phases were then shaken for 10 min with $1.5 \mathrm{ml}$ of $1 \mathrm{M}$ $\mathrm{HNO}_{3}$. The xylene phase was withdrawn and evaporated on a stainless steel planchet which was then flamed before counting.

The procedure for the $\operatorname{PrF}_{3}-$ TTA-xylene method for separating $\mathrm{Pu}$ (III) and $\mathrm{Pu}(\mathrm{IV})$ was as follows. A $1.0 \mathrm{ml}$ aliquot of sample was pipeted into a 15-ml plastic centrifuge tube and diluted to $5 \mathrm{ml}$ with deionized

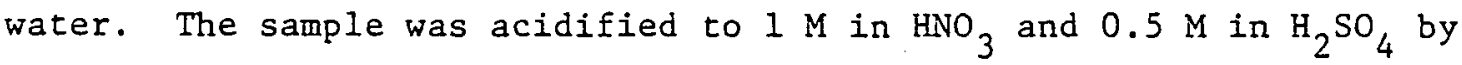
adding $350 \mu \mathrm{l}$ of conc. $\mathrm{HNO}_{3}$ and $150 \mu \mathrm{h}$ of conc. $\mathrm{H}_{2} \mathrm{SO}_{4} \cdot$ The sample was then made $0.02 \mathrm{M}$ in $\mathrm{Na}_{2} \mathrm{Cr}_{2} \mathrm{O}_{7}$ by adding $120 \mu \mathrm{l}$ of $1 \mathrm{M} \mathrm{Na}_{2} \mathrm{Cr}_{2} \mathrm{O}_{7}$. The dichromate was added to provide a holding oxidant environment in order to prevent any $\mathrm{Pu}(\mathrm{V} / \mathrm{VI})$ in the sample from being reduced during the procedure and therefore counted as Pu(IV). A $100 \mu \ell$ aliquot of $6 \%$ praeseodymium nitrate solution was added in order to total $2.0 \mathrm{mg}$ of praeseodymium in the sample. The sample was then made $2 \mathrm{M}$ in HF by 
adding $450 \mu \ell$ of conc. HF followed by mixing on a vortex mixer. After sitting for 5 min the $\operatorname{PrF}_{3}$ precipitate was centrifuged out and the supernatant was transferred to another 15-mI centrifuge tube. The

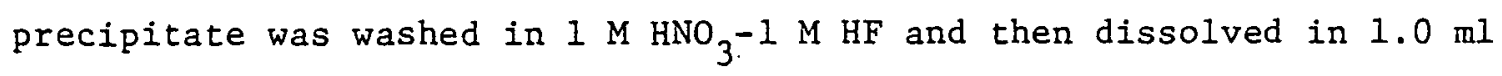
of $1 \mathrm{M} \mathrm{HNO}_{3}$ saturated with boric acid. If $\mathrm{Pu}$ (III) was to be included In the analysis, then five drops of $3 \mathrm{M} \mathrm{NaNO}_{3}$ were added to the dissolved precipitate followed by allowing the sample to sit for $10 \mathrm{~min}$. The $\mathrm{NaNO}_{3}$ oxidized the $\mathrm{Pu}(\mathrm{III})$ to $\mathrm{Pu}(\mathrm{IV})$. The sample was then taken through the TTA-xylene procedure.

The determine $\mathrm{Pu}(\mathrm{V})$ and/or $\mathrm{Pu}(\mathrm{VI})$ the $\mathrm{Ca}\left(\mathrm{NO}_{3}\right)_{2}$-hexone and/or $\mathrm{NH}_{2} \mathrm{OH} \cdot \mathrm{HCl}-\mathrm{PrF}_{3}-\mathrm{TTA}-\mathrm{xylene}$ methods were used (Bondietti and Reynolds, 1976). The $\mathrm{Ca}\left(\mathrm{NO}_{3}\right)_{2}$-hexone method was hased on forming an aqucous $\mathrm{Pu}(\mathrm{V} / \mathrm{VI})$ nitrate complex which was then extracted into the hexone phase. The $\mathrm{NH}_{2} \mathrm{OH} \cdot \mathrm{HCl}-\mathrm{PrF}_{3}-\mathrm{TTA}-\mathrm{xyl}$ ene method depended upon reducing the $\mathrm{Pu}(\mathrm{V} / \mathrm{VI})$ to $\mathrm{Pu}(\mathrm{III} / \mathrm{IV})$ prior to the $\mathrm{PrF}_{3}$ coprecipitation and TTA-xylene extraction steps.

To determine $\mathrm{Pu}(\mathrm{V})$ and/or $\mathrm{Pu}(\mathrm{VI})$ by the $\mathrm{Ca}\left(\mathrm{NO}_{3}\right)_{2}$-hexone method the aqueous phase remaining after the TTA-xylene extraction was made 3.5 to $4.0 \mathrm{M}$ in $\mathrm{Ca}\left(\mathrm{NO}_{3}\right)_{2}$ by adding $0.9 \mathrm{~g}$ of $\mathrm{Ca}\left(\mathrm{NO}_{3}\right)_{2} \cdot 4 \mathrm{H}_{2} \mathrm{O}$ and $0.01 \mathrm{M}$ in $\mathrm{KBrO}_{3}$ by adding 100 hl of $0.1 \mathrm{M} \mathrm{KBrO}_{3}$. A $1-\mathrm{ml}$ aliquot of pretreaten hexone was then added and shaken for 3 min. After phase separatiun the hexone phase was withdrawn and evaporated on a stain.less steel planchet. The extraction with hexone was repeated and the planchet was flamed before counting. To pretreat the hexone to destroy reducing agents and to equilibrate the hexone with acid, equal volumes of hexnne and $0.01 \mathrm{M}$ $\mathrm{KBrO}_{3}-1 \mathrm{MHNO}_{3}$ were shaken together and the aqueous phase was discarded. The hexone was stored over $0.01 \mathrm{M} \mathrm{KBrO}_{3}$ and $1 \mathrm{M} \mathrm{HNO}_{3}$. 
To determine $\mathrm{Pu}(\mathrm{V})$ and/or $\mathrm{Pu}(\mathrm{VI})$ by the $\mathrm{NH}_{2} \mathrm{OH} \cdot \mathrm{HCl}_{2}-\mathrm{PrF}_{3}-\mathrm{TTA}-\mathrm{xyl}$ ene method the supernatant from the $\operatorname{PrF}_{3}$ precipitation step outlined above was made $0.1 \mathrm{M}$ in $\mathrm{NH}_{2} \mathrm{OH} \cdot \mathrm{HCl}$ by adding $600 \mu$ of $1 \mathrm{M} \mathrm{NH}_{2} \mathrm{OH} \cdot \mathrm{HCl}$ to reduce any $\mathrm{Pu}(\mathrm{V})$ and/or $\mathrm{Pu}(\mathrm{VI})$ in the solution. Praeseodymium nitrate solution was then added to total $2.0 \mathrm{mg}$ of praeseodymium in the sample. After 5 min the precipitate was centrifuged out and washed in $1 \mathrm{MHNO}_{3}-1 \mathrm{MHF}$. The precipitate was dissolved in $1 \mathrm{M} \mathrm{HNO}_{3}$ saturated with boric acid and five drops of $3 \mathrm{M} \mathrm{NaNO}_{3}$ were added followed by letting the sample sit for $10 \mathrm{~min}$. The sample was then taken through the TTA-xylene method.

To extract all four oxidation states at one time, a 1.0-ml sample aliquot was made $0.1 \mathrm{M}$ in $\mathrm{NH}_{2} \mathrm{OH} \cdot \mathrm{HCl}$ followed by the PrF 3 -precipitation procedure and TTA-xylene procedure. The $\mathrm{Na}_{2} \mathrm{Cr}_{2} \mathrm{O}_{7}$ was omitted from the $\mathrm{PrF}_{3}$ procedure in this case.

The ${ }^{239} \mathrm{Pu}$ deposited on the planchets was determined by $\alpha$-spectrometry using a Canberra model 2201 proportional counter and a Canberra multichannel analyzer with a Harshaw surface barrier detector. In addition the ${ }^{241} \mathrm{Am}$ content of some of the soil extracts was determined by $\gamma$-spectrometry using a NaI(T1) detector.

\section{Chromium Experiments}

\section{Soil Sample Collection and Characterization}

Soil samples were collected in September 1979 from field plots established on Hagerstown silt loam (Typic Hapludalf; fine, mixed, mesic) amended with sewage sludge in 1974 and 1975. The sludge contained $660 \mu \mathrm{g}$ of $\mathrm{Cr}$ per gram of dry sludge as determined by digestion in $\mathrm{HNO}_{3}-$ $\mathrm{HClO}_{4}$ and atomic absorption spectrophotometry (AAS) analysis (Doty et a1., 1977), and was applied at rates resulting in total sludge applications of $0,11.2,22.4$, and $44.8 \mathrm{MT}$ (metric tons)/ha for the two years combined. 
This field experiment was a randomized complete block design with four replications. Details concerning other aspects of the experiment can be found in Baker et al. (1977, 1979).

For the purposes of this thesis two sets of soil samples were collected from these plots. One set was collected from the first block of sludge treatments, only. These samples were collected from the top 20 $\mathrm{cm}$ of soil, sieved through a 2 -mm plastic screen while still moist, and stored in plastic bags while still moist. The other set was collected from all four blocks of sludge treatments. These samples were also collected from the top 20 cn of suil, but were alr-drited before sieving and stored air-dried.

A soil sample was also collected in Seprember 1979 from a field plot established on Murrill silt loam (Typic Hapludult; fine-loamy, mixed, mesic) that was amended with sewage sludge in 1972 through 1979 at the rate of $11.2 \mathrm{MT} / \mathrm{ha} /$ year. A soil sample was also collected from a Chrome gravelly silty clay loam (Typic Hapludalf; fine, mixed, mesic) in Chester County, Pennsylvania. This soil developed over serpentine parent material known to be high in chromium (Pearre and Heyl, 1960). The sample was collected from an area of known chromite mineralization with several old chromium prospects and mines nearby. These two samples were collected from the top $20 \mathrm{~cm}$ of soil and were sieved and stored while still moist.

The water content of the collected soil samples was determined gravimetrically by oven drying at $105^{\circ} \mathrm{C}$ (Gardner, 1965). Organic matter content was determined by dichromate-sulfuric acid oxidation (Allson, 1965). The $\mathrm{pH}$ of the soil samples was determined by adding $5 \mathrm{ml}$ of deionized water to $5 \mathrm{~g}$ (dry weight basis) of moist soil, mixing the 
suspension, waiting 30 min with periodic mixing, and measuring the $\mathrm{pH}$ with a combination pH-reference electrode calibrated with pH 4 and 7 . buffers.

\section{Preparation of $\mathrm{MnO}$ Minerals}

The minerals $\delta-\mathrm{MnO}_{2}$, $\mathrm{Mn}(\mathrm{II})$-manganite, and $\alpha-\mathrm{MnO}_{2}$ were prepared according to methods described by Healy et al. (1965). The preparation of $\delta-\mathrm{MnO}_{2}$ and $\mathrm{Mn}(\mathrm{II})$-manganite can be described by the reaction:

$$
2 \mathrm{KMnO}_{4}+8 \mathrm{HCl}=2 \delta-\mathrm{MnO}_{2}+2 \mathrm{KCl}+3 \mathrm{Cl}_{2}+4 \mathrm{H}_{2} \mathrm{O}
$$

To prepare $\delta-\mathrm{MnO}_{2}$ a $0.2 \mathrm{M} \mathrm{KMnO}_{4}$ solution was heated to boiling and conc. HCl was added to bring the solution to $0.6 \mathrm{M}$ in $\mathrm{HC} 1$. This assured an excess of $\mathrm{KMnO}_{4}$ which was needed to maintain the oxidizing conditions necessary to yield $\delta-\mathrm{MnO}_{2}$. The solution was allowed to sit overnight to complete the reaction and to cool. The suspension was filtered through a fritted glass funnel under suction and washed with deionized water and then with $0.05 \mathrm{M} \mathrm{HClO}_{4}$ to remove unreacted $\mathrm{KMnO}_{4}$ and $\mathrm{HCl}$ as well as $\mathrm{KCl}$. The collected $\delta-\mathrm{MnO}_{2}$ was dried overnight at $60^{\circ} \mathrm{C}$ and ground with an agate mortar and pestle and stored until use. To prepare Mn(II)-manganite the same procedure was used except an excess of $\mathrm{HCl}$ was maintained in order to assure the reducing conditions, needed to produce Mn(II)-manganite. To prepare $\alpha-\mathrm{MnO}_{2}$ some of the Mn(II)-manganite product was suspended in diluted $\mathrm{KCl}$ solution, heated to boiling, and refluxed for $10 \mathrm{hr}$. This converted the $\mathrm{Mn}(\mathrm{II})$-manganite to $\alpha-\mathrm{MnO}_{2}$. The $\alpha-\mathrm{MnO}_{2}$ was washed and dried as described above. Reagent grade $\mathrm{B}-\mathrm{MnO}_{2}$ from Fisher Scientific Co. was washed with $0.05 \mathrm{M} \mathrm{HClO}_{4}$ to remove impurities and dried overnight at $60^{\circ} \mathrm{C}$. These minerals were characterized by Healy et al. (1965) and snine of the properties are listed in Table 5. 
Table 5. Propertie 3 of $\mathrm{MnO}_{2}$ mitierals.

\begin{tabular}{|c|c|c|}
\hline Mineral & Chemical Properties & Structural Properties \\
\hline$\delta-\mathrm{MnO}_{2}$ (birnessite) & $\begin{array}{l}0: \mathrm{Mr}_{-}=1.9 \\
\mathrm{ZPC} \sim 1.5\end{array}$ & $\begin{array}{l}\text { Forms layered structure, crystals } 2 \text { to } 3 \\
\text { atomic layers thick. BET surface area } \\
310 \mathrm{~m} / \mathrm{g} \text {. }\end{array}$ \\
\hline $\begin{array}{l}\text { Mn (II)-manganite } \\
\text { (manganous nanganite) } \\
\text { (10A manganite) }\end{array}$ & $\begin{array}{c}0: \mathrm{Mn}=1.7-1.9 \\
3 \mathrm{MnO}_{2} \cdot \mathrm{Mn}(\mathrm{C} \mathrm{CH})_{2} \cdot \mathrm{nH}_{2} \mathrm{O} \\
\quad \mathrm{ZPC} \sim 1.8\end{array}$ & $\begin{array}{l}\text { Double-layer structure. Main layers } \\
\text { conzain } \mathrm{Mn}^{4+} \text { in sixfold coordination } \\
\text { with } 0^{-2} \text { and are separated by a } 10 \mathrm{~A} \\
\text { space ccntaining Mn } 2+\text { coordinated with } \\
0^{-2} \cdot \mathrm{OH}^{-} \text {, and } \mathrm{H}_{2} \mathrm{O} \text {. BET surface area } \\
30-50 \mathrm{~m}^{2} / \mathrm{g} \text {. }\end{array}$ \\
\hline$\alpha-\mathrm{MnO}_{2}$ (cryptomelane) & $\begin{array}{l}\qquad \mathrm{KMn}_{\mathrm{g}^{\mathrm{O}}}{ }_{16} \\
\text { Shows cation exchange } \\
\text { properties } \\
\text { ZPC } \sim 4.5\end{array}$ & $\begin{array}{l}\text { Three-dimensional framework structure. } \\
\text { Structure held open by } \mathrm{K}^{+} \text {. }\end{array}$ \\
\hline $\mathrm{B}-\mathrm{MnO}_{2}$ (pyrolusite) & $\begin{array}{c}\mathrm{MnO}_{2} \\
\mathrm{ZPC} \sim 7.3\end{array}$ & Tetragonal rutile structure. \\
\hline
\end{tabular}


To determine the $\mathrm{Mn}$ content of the four $\mathrm{MnO}_{2}$ minerals, a weighed amount of each mineral was dissolved in a few milliliters of a dilute $\mathrm{NH}_{2} \mathrm{OH} \cdot \mathrm{HCl}-\mathrm{HNO}_{3}$ solution and diluted to $100 \mathrm{ml}$ in a volumetric flask. The manganese concentration in each flask was measured by AAS and the \% Mn content of each mineral calculated. The $M n$ content of the four minerals was found to be $45.5,46.0,52.0$, and $60.8 \%$ for $\delta-\mathrm{MnO}_{2}$, $\mathrm{Mn}$ (II) manganite, $\alpha-\mathrm{MnO}_{2}$, and $\mathrm{B}-\mathrm{MnO}_{2}$, respectively. This data was used to calculate the ratio of $\mathrm{Mn}$ (IV) to $\mathrm{Cr}$ (III) for the kinetic experiments described in a later section. To determine the capacity of $\delta-\mathrm{MnO}_{2}$ to oxidize $\mathrm{Cr}$ (III), $20 \mathrm{mg}$ of $\delta-\mathrm{MnO}_{2}$ were added to $1000 \mathrm{ml}$ of a $1000 \mu \mathrm{g} / \mathrm{ml}$ $\mathrm{Cr}$ (III) solution. The solution was mixed, heated to $50^{\circ} \mathrm{C}$ for two hours, cooled to room temperature, and analyzed for $\mathrm{Mn}$ (II) by AAS and $\mathrm{Cr}$ (VI) by the s-diphenylcarbazide method developed by Bartlett and James (1979). The $M(I I)$ concentration was found to be $171 \mu$ moles/l. If all of this was assumed to be $M(I V)$ initially, then according to the reaction stoichiometry $114 \mu$ moles/l of $\operatorname{Cr}(V I)$ should be produced. Since 122 umoles/l of $\operatorname{Cr}(V I)$ were actually found, one can conclude that essentially all of the $\delta-\mathrm{MnO}_{2}$ is capable of oxidizing $\mathrm{Cr}(\mathrm{III})$.

Extraction of Fulvic Mcid from

Leather Dust and Soil

Fulvic acid was extracted from leather dust and soil and partially purified according to the following procedure adapted from stevenson (1965). Four 250-ml plastic centrifuge bottles were each filled with $200 \mathrm{mI}$ of $0.5 \mathrm{M} \mathrm{NaOH}$. Nitrogen was bubbled through the $\mathrm{NaOH}$ solution in each bottle to remove dissolved oxygen. A 40-g sample of Murrill silt loam was added to each of two of the four bottles while a 5-g sample of leather dust contalning $2.6 \%$ Cr was added to each of the other two 
bottles. The bottles were shaken for 18 hours at $120 \mathrm{osc} / \mathrm{min}$ and centrifuged for $20 \mathrm{~min}$ at $12,000 \mathrm{~g}$. The supernatants were decanted into four new 250-ml plastic centrifuge bottles and the residues discarded. The supernatants were acidified to $\mathrm{pH} 1$ using $6 \mathrm{M} \mathrm{HCl}$ and allowed to stand $1 \mathrm{hr}$. Following centrifugation for $20 \mathrm{~min}$ at $12,000 \mathrm{~g}$ the supernatants were decanted into four new centrifuge bottles and the residues discarded. The supernatants were adjusted to $\mathrm{pH} 7$ using $5 \mathrm{M} \mathrm{NaOH}$ and allowed to stand $1 \mathrm{hr}$. Following centrifugation for 20 min at $12,000 \mathrm{~g}$ the supernatants were decanted and stored and the residues discarded. The fulvic acid contcnt of the pusified NaOH excracts was determined gravimetrically by drying and combustion. A measured volume of each extract was added to an evaporating dish previously heated to $550^{\circ} \mathrm{C}$ and weighed. The dishes were heated in an oven at $105^{\circ} \mathrm{C}$ overnight, cooled in a dessicator, reweighed, heated in a muffle oven at $550^{\circ} \mathrm{C}$ for 20 min, cooled in a dessicator, and reweighed. The fulvic acid content was calculated as the weight of organic matter lost on combustion per volume of sulution. The concentration of soil fulvic acid was found to be $944 \mathrm{mg} / \mathrm{l}$ while the concentration of leather dust fulvic acid was found to be $12.4 \mathrm{~g} / \mathrm{l}$.

\section{Chemical Fractionation of Soil $\mathrm{Cr}$ and $\mathrm{Mn}$}

The collected soil samples were extracted with $0.01 \mathrm{M} \mathrm{KH}_{2} \mathrm{Pn}_{4}$ to delecl any $\operatorname{Cr}$ (VI) present in these so1ls using a modification of the method developed by Bartlett and James (1979). Duplicate 5-g samples (dry weight basis) of each moist soil were added to 50-ml plastic centrifuge tubes. Twenty $\mathrm{ml}$ of $0.01 \mathrm{M} \mathrm{KH}_{2} \mathrm{PO}_{4}$ were added to each sample, followed by mixing on a vortex mixer, shaking for $15 \mathrm{~min}$ at $240 \mathrm{osc} / \mathrm{min}$, 
centrifuging for $10 \mathrm{~min}$ at $630 \mathrm{~g}$, filtering through $0.2 \mu \mathrm{m}$ membrane filters, and determining $\operatorname{Cr}(V I)$ in the extracts.

Chromium and $\mathrm{Mn}$ extractable with $\mathrm{NaOH}$ were determined on Hagerstown silt loam amended with $44 \mathrm{MT} / \mathrm{ha}$ sludge, Murrill silt loam, and the sludge used in the field experiments, using a modification of the Stevenson (1965) method. Duplicate 10-g samples (dry weight basis) of each moist soil were added to 100-ml plastic centrifuge tubes. Fifty ml of $0.5 \mathrm{M} \mathrm{NaOH}$ were added to each sample and the tubes were shaken for 12 hours at $120 \mathrm{osc} / \mathrm{min}$. The samples were centrifuged for $10 \mathrm{~min}$ at $630 \mathrm{~g}$ and the supernatants were decanted into Erlenmeyer flasks. An additional $50 \mathrm{ml}$ of $0.5 \mathrm{M} \mathrm{NaOH}$ were added to each sample followed by shaking for $1 \mathrm{hr}$, centrifuging, and decanting the supernatants into the Erlenmeyer flasks. Fifty $\mathrm{ml}$ of $1 \mathrm{M} \mathrm{NaCl}$ were added to each sample followed by mixing on a vortex mixer, centrifuging, and adding the supernatants to the Erlenmeyer flasks. The extracts were analyzed for total $\mathrm{Cr}$ and Mn by AAS.

Sodium pyrophosphate extractable $\mathrm{Cr}$ and $\mathrm{Mn}$ were also determined on the soil samples. Duplicate 5-g samples (dry weight basis) of each moist soil were shaken for $15 \mathrm{~min}$ at $240 \mathrm{osc} / \mathrm{min}$ with $25.0 \mathrm{ml}$ of $0.1 \mathrm{M}$ $\mathrm{Na}_{4} \mathrm{P}_{2} \mathrm{O}_{7}$. Following centrifugation of the samples for $10 \mathrm{~min}$ at $630 \mathrm{~g}$ the supernatants were acidified to $\mathrm{pH} 1$ using $6 \mathrm{M} \mathrm{HCl}$ and recentrifuged. The extractions were repeated four more times on the Hagerstown and Murrill soils and twice more on the Chrome soil and the extracts were analyzed for total $\mathrm{Cr}$ and $\mathrm{Mn}$.

All of the moist soil samples and the air-dried samples from the Hagerstown field plots were analyzed. for $\mathrm{pH} 9.5,5.25 \% \mathrm{NaOCl}$ extractable Cr and Mn using a modification of the method from Anderson (1963). 
Duplicate 5-g samples (dry weight basis) of each soil were added to 100$\mathrm{ml}$ plastic centrifuge tubes and $10 \mathrm{ml}$ of $5.25 \% \mathrm{NaOCl}$ adjusted to $\mathrm{pH} 9.5$ using $6 \mathrm{M} \mathrm{HCl}$ shortly before use were added to each sample. After mixing on a vortex mixer the tubes were placed in a boiling water bath for $15 \mathrm{~min}$, centrifuged for $10 \mathrm{~min}$ at $630 \mathrm{~g}$, and the supernatants decanted into $50-\mathrm{ml}$ volumetric flasks. The extractions were repeated twice more adding the supernatants each time to the volumetric flasks. The flasks were diluted to volume with deionized water, mixed, and the solutions analyzed for total $\mathrm{Cr}$ and $\mathrm{Mn}$.

Chromium and $\mathrm{Mn}$ cxtractable with $\mathrm{Il}_{2} \mathrm{O}_{2}$ were alsu determoned by a modification of the method of Taylor and McKenzie (1966). Duplicate 5-g samplas (dry wcight basis) of each lluisl soll were added to 100 -ml plastic centrifuge tubes and $25.0 \mathrm{ml}$ of $10 \% \mathrm{H}_{2} \mathrm{O}_{2}$ adjusted to $\mathrm{pH} 3$ with $\mathrm{HNO}_{3}$ were added to each tube. After mixing on a vortex mixer the samples were allowed to sit overnight, centrifuged for 10 min at $630 \mathrm{~g}$, and the supernatants analyzed for $\mathrm{Cr}$ and $\mathrm{Mn}$. The extraction steps were repeated twice more. Another $\mathrm{H}_{2} \mathrm{O}_{2}$ extractinn method was also ueed on the moist Hagerstown and Murrill samples. Duplicate 5-g samples (dry weight basis) of each soil were added to 500-ml Erlenmeyer flasks and $250 \mathrm{ml}$ of $10 \% \mathrm{H}_{2} \mathrm{O}_{2}$ adjusted to $\mathrm{pH}$ ? with $\mathrm{HNO}_{3}$ were added to each flask. After mixing and sitting overnight the suspensions were filtered and the filtrates were analyzed for total $\mathrm{Cr}$ and $\mathrm{Mn}$.

Hydroxylamine hydrochloride extractable $\mathrm{Cr}$ and $\mathrm{Mn}$ were determined using modifications of the Chao (1972) method. Duplicate 5-g samples (dry weight basis) of each moiet soil were added to 125-ml Erlenmeyer flasks and $25.0 \mathrm{ml}$ of $0.1 \mathrm{M} \mathrm{NH}_{2} \mathrm{OH} \cdot \mathrm{HCl}$ adjusted to $\mathrm{pH} 2$ using $\mathrm{HCl}$ were added. After mixing and sitting overnight the suspensions were filtered 
and the filtrates analyzed for total $\mathrm{Cr}$ and $\mathrm{Mn}$. Another $\mathrm{NH}_{2} \mathrm{OH} \cdot \mathrm{HCl}$ extraction procedure was also used on the moist Hagerstown and Murrill samples. The procedure was identical to the previously described extraction using $\mathrm{pH} 2,10 \% \mathrm{H}_{2} \mathrm{O}_{2}$ except that $\mathrm{pH} 2,0.1 \mathrm{M} \mathrm{NH}_{2} \mathrm{OH} \cdot \mathrm{HCl}$ was used in place of the $\mathrm{H}_{2} \mathrm{O}_{2}$.

The moist soil samples were also analyzed for total $\mathrm{Cr}$ and $\mathrm{Mn}$ using the $\mathrm{HF}-\mathrm{HNO}_{3}-\mathrm{H}_{2} \mathrm{SO}_{4}-\mathrm{HClO}_{4}$ digestion method described by Fiskell (1965) followed by AAS analysis. Teflon tubes and a block digester were used. A different method was used to determine total $\mathrm{Cr}$ in the air-dried samples collected from all four sets of field plots. This method used $\mathrm{H}_{2} \mathrm{O}_{2}, \mathrm{HNO}_{3}$, and $\mathrm{HCl}$ and although it would not extract the total natural Cr content of the soil, it was deemed suitable for extracting $\mathrm{Cr}$ added with the sludge. A 1.000-g sample of each soil was added to a teflon tube and $2 \mathrm{ml}$ of conc. $\mathrm{HNO}_{3}$ and $2 \mathrm{ml}$ of $10 \% \mathrm{H}_{2} \mathrm{O}_{2}$ were then added. The tubes were heated in a block digester to dryness. The addition of $\mathrm{HNO}_{3}$ and $\mathrm{H}_{2} \mathrm{O}_{2}$ and heating to dryness was repeated. Five $\mathrm{ml}$ of $6 \mathrm{M} \mathrm{HCl}$ were added, the tubes were warmed, and then the suspensions filtered into 100-ml volumetric flasks. The tubes and filter paper were rinsed with $0.1 \mathrm{M} \mathrm{HCl}$, the rinsings added to the flasks, and the flasks filled to volume with deionized water. The flask contents were analyzed for $\mathrm{Cr}$ and $\mathrm{Mn}$.

Fate of $\mathrm{Cr}$ from Sludge and Leather Dust Applied to Soil in Laboratory Incubation Experiments

Laboratory incubation experiments were run to determine if $\mathrm{Cr}$ in organic matter (leather dust or sludge) could.be oxidized when mixed with soil. In one experiment duplicate 500-g samples (dry weight basis) of moist Hagerstown soil amended with $44.8 \mathrm{MT} /$ ha 3 ludge were each 
amended with $50 \mathrm{~g}$ of leather dust with a $2.6 \% \mathrm{Cr}$ content. The leather dust was mixed into each soil after which deionized water was added. until a 50\% water content (dry weight basis) was obtained in each sample. The samples were kept sealed in plastic bags for seven months at room temperature. The bags were able to prevent moisture loss, but gases $\left(\mathrm{CO}_{2}\right.$ and $\left.\mathrm{O}_{2}\right)$ were able to diffuse in and out of the bags. At the end of this incubation time samples from each bag were analyzed for $\mathrm{pH} 9.5$, 5.25\% NaOC1 excractable Cr. Periodically, throughout the incubation period samples were also analyzed for $0.01 \mathrm{M} \mathrm{KH}_{2} \mathrm{PO}_{4}$ extractable $\mathrm{Cr}(\mathrm{VI})$. In another experiment duplicate 500-g eamples (dry wcight basis) of moist Hagerstown soil amended with $22.4 \mathrm{MT} /$ ha sludge were each amended with $10 \mathrm{~g}$ of leather duct. The lcather dust was mixed into each sample, ṇo deionized water was added, and the samples were kept sealed in plastic bags for three months at room temperature. At the end of this time period samples from each bag were analyzed for $\mathrm{pH} 9.5,5.25 \%$ extractable $\mathrm{Cr}$ and $0.01 \mathrm{M} \mathrm{KH}_{2} \mathrm{PO}_{4}$ extractable $\mathrm{Cr}(\mathrm{VI})$. This experiment was also done using $10 \mathrm{~g}$ of sludge $(660 \mathrm{\mu g} / \mathrm{g} \mathrm{Cr})$ per $500 \mathrm{~g}$ of snit.

\section{Effect of Drying, Storage Time, and Organic Matter}

Removal on the Ability of Soil to Oxidize $\mathrm{Cr}$

To evaluate the $\mathrm{Cr}$ oxidizing ability of the collected soils and to study the effects of drying, storage time, and organic matter removal on the oxidizing ability, the following experiments were performed. A portion of each of the moist Hagerstown silt loam and Murrill silt loam was allowed to air-dry in open petri dishes while another fraction of each soil was oven-dried overnight at $105^{\circ} \mathrm{C}$. A $5.0-\mathrm{g}$ sample (dry weight basis) of each moist, air-dried, and oven-dried soil was subjected to a modification of the Cr oxidation test of Bartlett and James (1979). 
The test consisted of adding $1.0 \mathrm{ml}$ of $1000 \mu \mathrm{g} / \mathrm{ml} \operatorname{Cr}$ (III) to the sample in a 50-ml plastic centrifuge tube, mixing on a vortex mixer, adding. $20.0 \mathrm{ml}$ of $0.01 \mathrm{M} \mathrm{KH}_{2} \mathrm{PO}_{4}$, mixing on a vortex mixer followed by shaking for $15 \mathrm{~min}$ at $240 \mathrm{osc} / \mathrm{min}$, centrifuging for 10 min at $630 \mathrm{~g}$, filtering through a $0.2 \mu \mathrm{m}$ membrane filter, and analyzing the filtrate for $\mathrm{Cr}$ (VI) by the s-diphenylcarbazide method. To determine Mn reduced during the Cr oxidation test, each residual soil sample after the $\mathrm{KH}_{2} \mathrm{PO}_{4}$ extraction was shaken for $15 \mathrm{~min}$ at $240 \mathrm{osc} / \mathrm{min}$ with $20.0 \mathrm{ml}$ of $0.5 \mathrm{M} \mathrm{CaCl}_{2}$, centrifuged, and the supernatants were analyzed for Mn(II) by AAS. To determine the original Mn(II) level in the soils plus the effect of drying on Mn reduction, a 5.0-g sample (dry weight basis) of each moist, air-dried, and oven-dried soil was extracted with $0.5 \mathrm{M} \mathrm{CaCl}_{2}$ as just described. To determine the effect of time of air-drying and whether . moist soil lost $\operatorname{Cr}$ oxidizing power over time, samples of air-dried and moist soils were periodically tested using the $\mathrm{Cr}$ oxidation test over the course of a year. To determine the effect of water removal by washing with organic solvents, $1.0 \mathrm{ml}$ of $1000 \mu \mathrm{g} / \mathrm{ml} \operatorname{Cr}$ (III) was added to each of six 5.0-g samples (dry weight basis) of moist Murrill silt loam in 50-ml centrifuge tubes. Each sample was subjected to a different treatment. To the first sample, nothing was done, the second sample was dried for several hours at $105^{\circ} \mathrm{C}$, the third sample was washed three times with $\sim 20 \mathrm{ml}$ of isopropyl alcohol, the fourth sample was washed with alcohol followed by oven-drying, the fifth sample was washed three times with $\sim 20 \mathrm{ml}$ of acetone, and the sixth sample was acetone washed and then oven-dried. Each sample was then extracted with $20.0 \mathrm{ml}$ of $0.01 \mathrm{M} \mathrm{KH}_{2} \mathrm{PO}_{4}$ as with the $\mathrm{Cr}$ oxidiation test and the extracts were analyzed for $\operatorname{Cr}(\mathrm{VI})$. To determine the effect of organic matter removal 
on $\mathrm{Cr}$ oxidizing ability, duplicate $5.0-\mathrm{g}$ samples (dry weight basis) of moist Hagerstown silt loam amended with $44.8 \mathrm{MT} /$ ha sludge were washed three times with $2 \% \mathrm{Na}_{2} \mathrm{CO}_{3}$ at $\mathrm{pH} 9.5$, treated three times with $\mathrm{pH} 9.5$, $5.25 \% \mathrm{NaOCl}$, and washed five times with $\mathrm{pH} 9.5,2 \% \mathrm{Na}_{2} \mathrm{CO}_{3}$ followed by the Cr oxidation test.

\section{Cr Oxidizing Capacity of Soil}

A 16-g sample (dry weight basis) of moist Hagerstown silt loam amended with $44.8 \mathrm{MT} / \mathrm{ha}$ sludge was added to a 50-ml plastic centrifuge tube. Twenty $\mathrm{ml}$ of $1000 \mu \mathrm{g} / \mathrm{mI} \mathrm{Cr}($ III) solution were added followed by mixing and shaking for 15 min at 240 osc/min. After centrifuging for 10 min at $630 \mathrm{~g}$ the supernatant was filtered through a $0.2 \mathrm{\mu m}$ membrane filter and analyzed for total $\mathrm{Cr}, \operatorname{Cr}(V I)$, and $\mathrm{Mn}(\mathrm{II})$. This extraction procedure was repeated five more times in order to exhaust the soil's capacity to oxidize $\mathrm{Cr}$.

\section{Effect of $C r$ Concentration on $\mathrm{Cr}$ Oxidation by Soil}

A 20-g sample (dry weight hasis) of moist Hagerstown 3ilt loam. amended with $44.8 \mathrm{MT} / \mathrm{ha}$ sludge was added to each of eight 50-ml plastic centrifuge tubes. A set of eight $\operatorname{Cr}$ (III) solutions each with a different $\operatorname{Cr}($ III) concentration $(0,1,5,10,50,100,500$, and $1000 \mu \mathrm{g} / \mathrm{ml}$ $\operatorname{Cr}($ III)) was prepared and $20.0 \mathrm{ml}$ of each solution were added to the tubes, one Cr(III) level per soil sample. The samples were shaken for $15 \mathrm{~min}$ at $240 \mathrm{osc} / \mathrm{min}$, centrifuged for $10 \mathrm{~min}$ at $630 \mathrm{~g}$, and filtered through $0.2 \mu \mathrm{m}$ membrane filters. The filtrates were analyzed for total $\mathrm{Cr}$ and $\operatorname{Cr}(\mathrm{VT})$. Following washing cach sample three times with acetone, each sample was extracted with $20.0 \mathrm{ml}$ of $0.01 \mathrm{M} \mathrm{KH}_{2} \mathrm{PO}_{4}$ for $15 \mathrm{~min}$ at 
$240 \mathrm{osc} / \mathrm{min}$ shaking speed. After centrifugation and filtration the extracts were analyzed for $\operatorname{Cr}(V I)$. The experiment was replicated.

Extractability of $\mathrm{Cr}(\mathrm{VI})$ with $\mathrm{KH}_{2} \mathrm{PO}_{4}$

Several experiments were conducted to study the suitability of using $\mathrm{KH}_{2} \mathrm{PO}_{4}$ as an extractant for $\mathrm{Cr}(\mathrm{VI})$ in soil. In the first, the extraction of soil $\mathrm{Cr}(\mathrm{VI})$ using varying concentrations of $\mathrm{KH}_{2} \mathrm{PO}_{4}$ was studied. A 20-g sample (dry weight basis) of moist Hagerstown silt loam amended with $44.8 \mathrm{MT} / \mathrm{ha}$ sludge was added to each of three 50-ml plastic centrifuge tubes. A $20.0 \mathrm{ml}$ aliquot of $1000 \mu \mathrm{g} / \mathrm{ml} \mathrm{Cr}$ (III) solution was added to each sample followed by shaking for $15 \mathrm{~min}$ at $240 \mathrm{osc} / \mathrm{min}$, centrifuging for 10 min at $630 \mathrm{~g}$, and discarding the supernatants. To the first tube was added $20.0 \mathrm{ml}$ of $0.1 \mathrm{M} \mathrm{KH}_{2} \mathrm{PO}_{4}$, to the second, $20.0 \mathrm{ml}$ of $0.01 \mathrm{M} \mathrm{KH}_{2} \mathrm{PO}_{4}$, and to the third, $20.0 \mathrm{ml}$ of $0.001 \mathrm{M} \mathrm{KH}_{2} \mathrm{PO}_{4}$. Following shaking for $15 \mathrm{~min}$ at $240 \mathrm{osc} / \mathrm{min}$, centrifuging for $10 \mathrm{~min}$ at $630 \mathrm{~g}$, and filtering through $0.2 \mu \mathrm{m}$ membrane filters, the extracts were analyzed for $\operatorname{Cr}(V I)$.

The successive extraction of soil $\mathrm{Cr}(\mathrm{VI})$ with $0.01 \mathrm{M} \mathrm{KH}_{2} \mathrm{PO}_{4}$ was also studied. In this experiment $20 \mathrm{~g}$ (dry weight basis) of moist Hagerstown silt loam amended with $44.8 \mathrm{MT} /$ ha sludge was treated with $20.0 \mathrm{ml}$ of $1000 \mathrm{Hg} / \mathrm{ml} \mathrm{Cr}($ III) solution as before. The sample was then successively extracted with $20.0 \mathrm{ml}$ portions of $0.01 \mathrm{M} \mathrm{KH}_{2} \mathrm{PO}_{4}$ until negligible $\operatorname{Cr}(V I)$ level was found in the extract. The experiment was repeated using 10 and $100 \mathrm{\mu g} / \mathrm{ml} \operatorname{Cr}($ III) solutions.

A series of experiments was also run to examine the effect of soil/solution ratio on $\mathrm{Cr}(\mathrm{VI})$ extraction by $\mathrm{KH}_{2} \mathrm{PO}_{4} \cdot$ The conditions of these experiments are sumarized in Table 6 . In the first experiment the soil/solution ratio was changed by varying the amount of soil and 
Table 6. Conditions for experiments on the effect of soil/solution ratio on extraction of soil Cr(VI) by $\mathrm{KH}_{2} \mathrm{PO}_{4}$.

\begin{tabular}{|c|c|c|c|}
\hline Soil Amount & $\begin{array}{l}\text { Volume of } \\
1000 \mu \mathrm{g} / \mathrm{mil} \mathrm{Cr}^{3+}\end{array}$ & $\begin{array}{c}\text { Volume of } 0.01 \mathrm{M} \\
\mathrm{KH}_{2} \mathrm{PO}_{4} \text { Extracting Salution }\end{array}$ & Soil/Solution Ratio \\
\hline g. & $-\cdots-\cdots-\cdots--$ & n1-- & $\mathrm{g} / \mathrm{ml}$ \\
\hline \multicolumn{4}{|l|}{ Experiment 1} \\
\hline 5 & 5.0 & 20.0 & $1: 4$ \\
\hline 10 & 10.0 & 20.0 & $1: 2$ \\
\hline 15 & 15.0 & 20.0 & $1: 1.33$ \\
\hline 20 & 20.0 & 20.0 & $1: 1$ \\
\hline \multicolumn{4}{|l|}{ Experiment 2} \\
\hline 5 & 5.0 & 5.0 & $1: 1$ \\
\hline 5 & 5.0 & 10.0 & $1: 2$ \\
\hline 5 & 5.0 & 15.0 & $1: 3$ \\
\hline 5 & 5.0 & 20.0 & $1: 4$ \\
\hline \multicolumn{4}{|l|}{ Experiment 3} \\
\hline 5 & $\Xi .0$ & 5.0 & $1: 1$ \\
\hline 10 & $1 C .0$ & 10.0 & $1: 1$ \\
\hline 15 & 15.0 & 15.0 & $1: 1$ \\
\hline 20 & 20.0 & 20.0 & $1: i$ \\
\hline
\end{tabular}


holding the volume of $\mathrm{KH}_{2} \mathrm{PO}_{4}$ solution constant. In the second experiment the amount of soil was held constant while the solution volume was varied. In the third experiment both the soil amount and solution volume were varied, but the ratio was held constant. The extraction procedures were the same as already outlined. All of the experiments described above were replicated.

Oxidation of Cr from Different Sources at

Selected Concentrations in Soil with Time

Various incubation experiments were done in order to study the oxidation of $\mathrm{Cr}$ from different sources at selected concentrations with time. In the first experiment four 100-g samples (dry weight basis) of moist Murrill silt loam in plastic bags were treated with $0,1,5$, and $10 \mathrm{ml}$ of a $1000 \mu \mathrm{g} / \mathrm{ml} \mathrm{Cr}($ III) solution, one $\mathrm{Cr}$ treatment per sample, to yield levels of $0,10,50$, and $100 \mu \mathrm{g} / \mathrm{g}$ of soil $\mathrm{Cr}$. Deionized water was added to each sample to bring the soils to a $50 \%$ water content by weight. The soils were mixed in the bags to insure even distribution of the $\mathrm{Cr}$ treatments. At periodic intervals samples of wet soil from each bag were extracted by an immiscible displacement-centrifugation method (Mubarak and 01sen; 1976). The extraction consisted of adding $15 \mathrm{~g}$ of wet soil from each bag to 50-ml centrifuge tubes, adding $10 \mathrm{ml}$ of chloroform to each tube, and centrifuging for $1 \mathrm{hr}$ at $48,300 \mathrm{~g}$. The aqueous phases were withdrawn and analyzed for total $\mathrm{Cr}$ and $\mathrm{Cr}$ (VI). At periodic intervals $6-g$ samples of wet soil from each bag were extracted with $20.0 \mathrm{ml}$ of $0.01 \mathrm{M} \mathrm{KH}_{2} \mathrm{PO}_{4}$ for $30 \mathrm{~min}$ at $180 \mathrm{osc} / \mathrm{min}$, centrifuged for $10 \mathrm{~min}$ at $630 \mathrm{~g}$, and filtered through $0.2 \mu \mathrm{m}$ membrane filters. The filtrates were analyzed for $\operatorname{Cr}(V I)$. 
In another experiment $300 \mathrm{~g}$ (dry weight basis) of moist Murril1 silt loam were amended with $3.0 \mathrm{ml}$ of a $1000 \mu \mathrm{g} / \mathrm{ml} \mathrm{Cr}^{3+}$ solution to provide soil $\mathrm{Cr}$ level of $10 \mu \mathrm{g} / \mathrm{g}$. The soil was brought to a $100 \%$ water content with deionized water and mixed. At periodic intervals samples of the slurry were filtered through $0.2 \mu \mathrm{m}$ membrane filters and the filtrates were analyzed for $\operatorname{Cr}(\mathrm{VI})$ and $\mathrm{pH}$.

In another experiment $500 \mathrm{~g}$ (wet weight basis) of moist Hagerstown silt loam amended, with $44.8 \mathrm{MT} / \mathrm{h}$ s sludge were amended with 50 \& of $\mathrm{Cr}_{2} \mathrm{O}_{3}$ and $100 \mathrm{ml}$ of deionized water. The soil was mixed and at periodic intervals $5-g$ samples (dry weight basis) were extracted with $0.01 . \mathrm{M}$ $\mathrm{KH}_{2} \mathrm{PO}_{4}$ as described above and the extracts were analyzed for $\mathrm{Cr}(\mathrm{VI})$. In the final incubation experiment two 500-Q samplas (Ary weight basis) of moist Hagerstown silt loam were amended with 5 and $50 \mathrm{ml}$ of $1000 \mu \mathrm{g} / \mathrm{ml} \mathrm{Cr}$ (III) solution to provide soil $\mathrm{Cr}$ levels of 10 and 100 L૬'g, respectively. Two additional 500-g samples were amended with 5 and $50 \mathrm{ml}$ of a $1000 \mu \mathrm{g} / \mathrm{ml} \mathrm{Cr}$ (III) as $\mathrm{Cr}(\mathrm{OH})_{3}$ suspension to provide soil $\mathrm{Cr}$ levels of 10 and $100 \mathrm{\mu g} / \overline{\mathrm{g}}$. The $\mathrm{Cr}(\mathrm{OH})_{3}$ suspension was prepared by adjusting the $\mathrm{pH}$ of $1000 \mu \mathrm{g} / \mathrm{ml} \mathrm{Cr}$ (III) solution to 10 with $\mathrm{NaOH}$. Freshly precipitated $\mathrm{Cr}(\mathrm{OH})_{3}$ was used. The samples were brought to a $50 \%$ water content by weight and mixed thoroughly. At periodic intervals the soil solution was extracted by the imniscible displacement-centrifugation method and analyzed for $C_{r}(V I)$ and $p H$. Extrastions with $\cap . M I M$ $\mathrm{KH}_{2} \mathrm{PO}_{4}$ were also run and $\mathrm{Cr}(\mathrm{VI})$ determined in the extracts.

\section{Kinetics of $\mathrm{Cr}$ Oxidation by Mo1st}

Hagerstown Silt Loam

A summary of the reaction conditions for experiments on the kinetics of $\mathrm{Cr}$ oxidation by moist Hagerstown silt loam is given in Table 7. The 
Table 7. Summary of reaction conditions for experiments on the kinetics of $\mathrm{Cr}$ oxidation by moist Hagerstown silt loam.

\begin{tabular}{|c|c|c|c|c|c|c|}
\hline Sample Amount & Solution Volume & Solution Composition & [Soil] & {$[\operatorname{Cr}(\operatorname{III})]_{0}$} & $\mathrm{pH}$ & Temp. \\
\hline 8 & $\mathrm{~m} 1$ & & $g / \ell$ & umole/l & & ${ }^{\circ} \mathrm{C}$ \\
\hline 10 & 800 & $\begin{array}{l}2.5 \times 10^{-4} \mathrm{~m} \mathrm{KCl} \\
10 \times 10^{-4} \mathrm{~m} \mathrm{MgCl}_{2} \\
50 \times 10^{-4} \mathrm{~m} \mathrm{CaCl}_{2}\end{array}$ & 12.5 & 192 & 5.5 & 2 \\
\hline 10 & 800 & $\begin{array}{l}2.5 \times 10^{-4} \mathrm{~m} \mathrm{KCl} \\
10 \times 10^{-4} \mathrm{~m} \mathrm{MgCl}_{2} \\
50 \times 10^{-4} \mathrm{~m} \mathrm{CaCl}_{2}\end{array}$ & 12.5 & 192 & 5.5 & 23 \\
\hline 10 & 800 & $\begin{array}{l}2.5 \times 10^{-4} \mathrm{~m} \mathrm{KCl} \\
10 \times 10^{-4} \mathrm{~m} \mathrm{MgCl}_{2} \\
50 \times 10^{-4} \mathrm{~m} \mathrm{CaCl}_{2}\end{array}$ & 12.5 & 192 & 5.5 & 28 \\
\hline 10 & 800 & $\begin{array}{l}2.5 \times 10^{-4} \mathrm{~m} \mathrm{KCl} \\
10 \times 10^{-4} \mathrm{~m} \mathrm{MgCl}_{2} \\
50 \times 10^{-4} \mathrm{~m} \mathrm{CaCl}_{2}\end{array}$ & 12.5 & 192 & 5.5 & 50 \\
\hline 10 & 800 & $0.01 \mathrm{M} \mathrm{CaCl}_{2}$ & 12.5 & 192 & 5.5 & 27 \\
\hline $10 *$ & 800 & $0.01 \mathrm{M} \mathrm{CaCl}_{2}$ & 12.5 & 192 & 5.5 & 27 \\
\hline 10 & 800 & $\begin{array}{l}2.5 \times 10^{-4} \mathrm{~m} \mathrm{KCl} \\
10 \times 10^{-4} \mathrm{~m} \mathrm{MgCl}_{2} \\
50 \times 10^{-4} \mathrm{~m} \mathrm{CaCl}_{2} \\
4 \times 10^{-4} \mathrm{~m} \mathrm{DTPA}^{2}\end{array}$ & 12.5 & 192 & 5.5 & 26 \\
\hline
\end{tabular}

*Organic matter removed from scil using pH 9.5, $5.25 \% \mathrm{NaOCl}$. 
experimental apparatus used in these experiments is shown in Figure 9. It included a gas diffuser for bubbling $\mathrm{N}_{2}$ through the suspension to sweep dissolved $\mathrm{CO}_{2}$ out, a port for the addition of $\mathrm{Cr}$ (III) solution, a syringe sampler, a stirrer, a combination pH-reference electrode for monitoring the suspension $\mathrm{pH}$, and a delivery tube for $0.01 \mathrm{M} \mathrm{NaOH}$ to adjust the suspension $\mathrm{pH}$. The $\mathrm{pH}$ electrode and $\mathrm{NaOH}$ delivery tube were connected to a Fisher auto-titrator set to hold a constant $\mathrm{pH}$ ( $\mathrm{pH}$ stat).

A typical kinetic experionent was rum as follows. A 1.n-g sample (dry weight basis) of soil was added to the reaction vessel. The vessel was filled with 792 ml of equilibrating soliution (see Table 7 for solution compositions) and the experimental apparatus was assembled as shown in Figure 9. The assembled apparatus was placed in a constant temperature bath (see Table 7 for experimental temperatures), the stirrer was turned on, the $\mathrm{N}_{2}$ flow was begun, and the auto-titrator was started to adjust the $\mathrm{pH}$ to the preset level (see Table 7 for experimental pH values). The suspension was all,owed to equilibrate until thermal equilibrium was reached as measured by a thermometer and the $\mathrm{pH}$ was constant. At time zero $8.0 \mathrm{ml}$ of $1000 \mathrm{\mu g} / \mathrm{ml} \mathrm{Cr}$ (III) solution was rapidly added. This resulted in a total volume of $800 \mathrm{ml}$, a soil concentration of 12.5 $\mathrm{g} / \ell$, and an initial $\mathrm{Cr}$ (III) concentration of $10 \mu \mathrm{g} / \mathrm{ml}$. At periodic intervals the suspension was sampled by means of the syringe sampler, filtered through $0.2 \mu \mathrm{m}$ membrane filters, and the filtrates analyzed for total Cr by AAS and Cr(VI) by the s-diphenylcarbazide method. Typically, sampling took less than 5 to $10 \mathrm{sec}$ while filtering took 15 to $25 \mathrm{sec}$ per sample. Temperature control was generally $\pm I^{\circ} \mathrm{C}$. The $\mathrm{pH}$ and $\mathrm{ml} n \mathrm{n}$. $\mathrm{NaOH}$ added after the addition of $\mathrm{Cr}$ (III) were monitored on strip-chart recorders. 


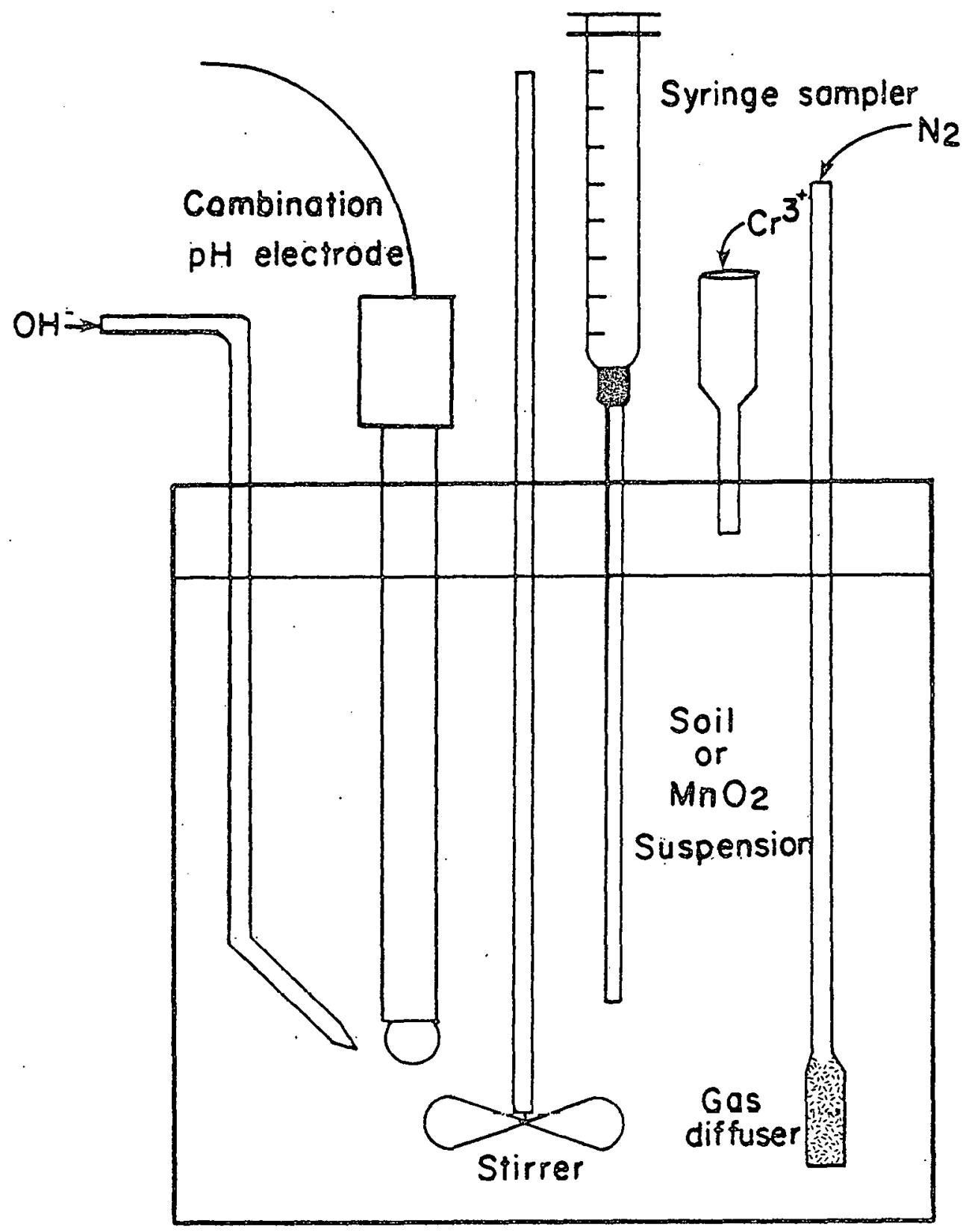

Figure 9. Experimental apparatus for studying the kinetics of $\mathrm{Cr}$ oxidation by moist Hagerstown silt loam and manganese oxide suspensions. 
Kinetics of $\mathrm{Cr}$ Oxidation by $\mathrm{MnO}_{2}$ Minerals

A summary of the reaction conditions for experiments on the kinetics of $\mathrm{Cr}$ oxidation by manganese oxide minerals is given in Table 8 . The experimental set-up was identical to that used for the soil experiments. A typical kinetic run for experiments where $\mathrm{MnO}_{2}$ was in excess consisted of the following procedure. The $\mathrm{MnO}_{2}$ mineral was weighed into the reaction vessel and the equilibrating solution was added. The $\mathrm{MnO}_{2}$ mineral concentrations and solution compositions used in the various experiments are listed in Table 8 . The experimental apparatus was assembled and placed in a constant temperature bath (scc Table 8 for experimental temperatures), the stirrer was turned on, the $\mathrm{N}_{2}$ flow begun, and the allo-titrator was etarted to adjust the pll tu lle present level (see Table 8 for experimental pH values). The suspension was allowed to equilibrate until the temperature and $\mathrm{pH}$ were constant. At time zero a measured volume of $1000 \mu \mathrm{g} / \mathrm{ml} \mathrm{Cr}$ (III) solution was rapidly added to achieve the desired initial $\operatorname{Cr}$ (III) concentration (see Table 8). At periodic intervals the suspension was sampled hy means of the syringe sampler, filtered through $0.2 \mu \mathrm{m}$ membrane filters, and the filtrates analyzed for total $\mathrm{Cr}$ by AAS and $\mathrm{Cr}(\mathrm{VI})$ by the s-diphenylcarbazide method. Typically, sampling took less than 5 to 10 eec and filtering took 15 to $25 \mathrm{sec}$. Temperature control was generally $\pm 1^{\circ} \mathrm{C}$. The $\mathrm{pH}$ and $\mathrm{ml}$ of $\mathrm{NaOH}$ adien after tho addition of $\mathrm{Cr}$ (III) were munlluled on scr1p-chart recorders. For experiments in which the pH stat was not used the $\mathrm{NaOH}$ delivery tube, $\mathrm{pH}$ electrode, $\mathrm{N}_{2}$ gas diffuser, and autotitrator were omitted from the experimental set-up. Howcver, an initial $\mathrm{pH}$ adjustment of the suspension was performed before the $\mathrm{Cr}$ (III) was added. Perchloric acid and $\mathrm{NaOH}$ were used for $\mathrm{pH}$ adjustments. For 
Table 8. Summary of reaction conditions for experiments on the kinetics of $\mathrm{Cr}$ oxidation by. manganese oxide minerals.

\begin{tabular}{|c|c|c|c|c|c|c|c|c|}
\hline $\begin{array}{c}\mathrm{MnO}_{2} \\
\text { Mineral }\end{array}$ & $\begin{array}{c}\mathrm{MnO}_{2} \\
\text { Amount }\end{array}$ & $\begin{array}{l}\text { Solution } \\
\text { Volume }\end{array}$ & Solution Composition & {$\left[\mathrm{MnO}_{2}\right]$} & {$[\operatorname{Cr}(\operatorname{III})]_{0}$} & $\operatorname{Mn}(I V) / \operatorname{Cr}(I I I)$ & $\mathrm{pH}$ & Temp. \\
\hline & $\mathrm{mg}$ & $\mathrm{ml}$ & & $\mathrm{mg} / \ell$ & $\mu$ mole/ $/ \ell$ & & & ${ }^{\circ} \mathrm{C}$ \\
\hline $\mathrm{S}^{-\mathrm{MnO}_{2}}$ & 200 & 800 & $10^{-3} \mathrm{M} \mathrm{NaClO}_{4}$ & 250 & 24.0 & 86 & 5.5 & 2 \\
\hline $\mathrm{s}-\mathrm{MnO}_{2}$ & 200 & 800 & $10^{-3} \mathrm{M} \mathrm{NaClO}_{4}$ & 250 & 24.0 & 86 & 5.5 & 28 \\
\hline $\mathrm{E}-\mathrm{MnO}_{2}$ & 200 & 800 & $10^{-3} \mathrm{M} \mathrm{NaClO}_{4}$ & 250 & 24.0 & 86 & 5.5 & 50 \\
\hline$\delta-\mathrm{MnO}_{2}$ & 100 & 400 & $0.1 \mathrm{M} \mathrm{HClO}_{4}$ & 250 & 24.0 & 86 & $1.0 * *$ & 28 \\
\hline$\delta-\mathrm{MnO}_{2}$ & 500 & 500 & $0.1 \mathrm{M} \mathrm{HClO}_{4}$ & 1000 & 38.4 & 215 & $1.0 * *$ & 2 \\
\hline $\mathrm{o}-\mathrm{MnO}_{2}$ & 500 & 500 & $0.1 \mathrm{M} \mathrm{HClO}_{4}$ & 1000 & 38.4 & 215 & $1.0 * *$ & 24 \\
\hline$\hat{\mathrm{o}}-\mathrm{MnO}_{2}$ & 500 & 500 & $0.1 \mathrm{M} \mathrm{HClO}_{4}$ & 1000 & 38.4 & 215 & $1.0 * *$ & 48 \\
\hline$\hat{\mathrm{o}}-\mathrm{MnO}_{2}$ & 100 & 400 & $10^{-3} \mathrm{M} \mathrm{HClO}_{4}$ & 250 & 24.0 & 86 & $3.0 * x$ & 28 \\
\hline$\delta-\mathrm{MnO}_{2}$ & 200 & 800 & $10^{-3} \mathrm{M} \mathrm{NaClO}_{4}$ & 250 & 24.0 & 86 & 7.5 & 28 \\
\hline$\delta-\mathrm{MnO}_{2}$ & 200 & 800 & $10^{-3} \mathrm{M} \mathrm{NaClO}_{4}$ & 250 & 24.0 & 86 & $10 * *$ & 26 \\
\hline$\hat{\mathrm{o}}-\mathrm{MnO}_{2}$ & 200 & 800 & $0.1 \mathrm{M} \mathrm{NaClO}$ & 250 & 24.0 & 86 & 5.5 & 29 \\
\hline$\hat{\mathrm{o}}-\mathrm{MnO}_{2}$ & 200 & 800 & $\begin{array}{l}2.5 \times 10^{-4} \mathrm{~m} \mathrm{KCl} \\
10 \times 10^{-4} \mathrm{~m} \mathrm{MgCl}_{2} \\
50 \times 10^{-4} \mathrm{~m} \mathrm{CaCl}_{2}\end{array}$ & 250 & 24.0 & 86 & 5.5 & 26 \\
\hline$\hat{0}-\mathrm{MnO}_{2}$ & 200 & 800 & $\begin{array}{l}2.5 \times 10^{-4} \mathrm{~m} \mathrm{KCl} \\
10 \times 10^{-4} \mathrm{~m} \mathrm{MgCl}_{2} \\
50 \times 10^{-4} \mathrm{~m} \mathrm{CaCl}_{2} \\
4 \times 10^{-4} \mathrm{~m} \mathrm{DTPA}\end{array}$ & 250 & 24.0 & 86 & 5.5 & 26 \\
\hline
\end{tabular}


Table 8 (Continued).

\begin{tabular}{|c|c|c|c|c|c|c|c|c|}
\hline $\begin{array}{c}\mathrm{MnO}_{2} \\
\text { Mineral }\end{array}$ & $\begin{array}{c}\mathrm{MnO}_{2} \\
\text { Amount }\end{array}$ & $\begin{array}{c}\text { Soluticn } \\
\text { Volume }\end{array}$ & Solution Composition & {$\left[\mathrm{MnO}_{2}\right]$} & {$\left[\mathrm{Cr}\left(\mathrm{II}^{\prime}\right)\right]_{0}$} & $\operatorname{Mn}(\mathbb{E V}) / \mathrm{Cr}(\mathrm{III})$ & $\mathrm{pH}$ & Tenp. \\
\hline & $\mathrm{mg}$ & $\mathrm{m} 1$ & $\cdot$ & $\mathrm{mg} / \mathrm{l}$ & Hmoleisi & & & ${ }^{\circ} \mathrm{C}$ \\
\hline \multirow[t]{2}{*}{$\delta-\mathrm{MnO}_{2}$} & 200 & 800 & $\begin{array}{l}2.5 \times 10^{-4} \mathrm{~m} \mathrm{KCl} \\
10 \times 10^{-4} \mathrm{~m} \mathrm{MgCl} 2 \\
50 \times 10^{-4} \mathrm{~m} \mathrm{CaCl} 2\end{array}$ & 250 & 24.0 & 86 & 5.5 & 23 \\
\hline & & & 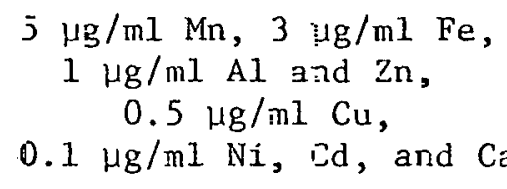 & & & & & \\
\hline$\delta-\mathrm{MnO}_{2}$ & $2 \mathrm{CO}$ & 800 & $1000 \mu \mathrm{g} / \mathrm{mL} \mathrm{Fe}$ & 250 & $24 . \mathrm{C}$ & 86 & 5.5 & 29 \\
\hline$\hat{\mathrm{c}}-\mathrm{MnO}_{2}$ & 20 & 500 & $10^{-3} \mathrm{M} \mathrm{NaClO}_{4}$ & $40 *$ & 19.2 & 17.2 & $\sim 7 * *$ & $2 \varepsilon$ \\
\hline$\delta-\mathrm{MnO}_{2}$ & 10 & 500 & $10^{-3} \mathrm{M} \mathrm{NaClO}_{4}$ & $20 *$ & 19.2 & 8.6 & $\sim 7 * *$ & 28 \\
\hline$\delta-\mathrm{MnO}_{2}$ & 5 & 500 & $10^{-3} \mathrm{M} \mathrm{NaClO}_{4}$ & $10^{*}$ & 19.2 & 4.3 & $\sim 7 * *$ & 28 \\
\hline$\delta-\mathrm{MnO}_{2}$ & 2.8 & 500 & $10^{-3} \mathrm{M} \mathrm{NaClO}_{4}$ & $5.6 *$ & 19.2 & 2.4 & $\sim 7 * *$ & 28 \\
\hline$\delta-\mathrm{MnO}_{2}$ & 10 & 500 & $1000 \mathrm{\mu g} / \mathrm{mI} \operatorname{Cr}(\mathrm{III})$ & $20 *$ & $19,230 \cdots x+$ & 0.0086 & $2.6 * * x$ & 28 \\
\hline$\delta-\mathrm{MnO}_{2}$ & 1 & 500 & $1000 \mu \mathrm{g} / \mathrm{m}_{-}^{-} \operatorname{Cr}(\mathrm{III})$ & 2 & $19,230 * x * x$ & 0.00086 & $1.0 * *$ & 25 \\
\hline$\delta-\mathrm{MnO}_{2}$ & 1 & 500 & $=000 \mu \mathrm{g} / \mathrm{ml} \operatorname{Cr}(\mathrm{III})$ & 2 & $19,230 * x *$ & 0.00086 & $1.0 * *$ & 48 \\
\hline $\begin{array}{l}\text { Mn (II)- } \\
\text { manganite }\end{array}$ & 200 & 800 & $10^{-3} \mathrm{M} \mathrm{NaClO}_{4}$ & 250 & 24.0 & 87 & 5.5 & 28 \\
\hline $\begin{array}{l}\text { Mn (II)- } \\
\text { manganite }\end{array}$ & 10 & 500 & $10^{-3} \mathrm{M} \mathrm{NaClO}_{4}$ & $20 *$ & 19.2 & 8.7 & $\sim 7 * *$ & 28 \\
\hline$\alpha-\mathrm{MnO}_{2}$ & 200 & 800 & $10^{-3} \mathrm{M} \mathrm{NaClO}_{4}$ & 250 & 24.0 & 98 & 5.5 & 27 \\
\hline
\end{tabular}


Table 8 (Continued).

\begin{tabular}{|c|c|c|c|c|c|c|c|c|}
\hline $\begin{array}{l}\mathrm{MnO}_{2} \\
\text { Mineral }\end{array}$ & $\begin{array}{c}\mathrm{MnO}_{2} \\
\text { Amount }\end{array}$ & $\begin{array}{l}\text { Solution } \\
\text { Volume }\end{array}$ & Solution Composition & {$\left[\mathrm{MnO}_{2}\right]$} & {$[\operatorname{Cr}(\operatorname{III})]_{0}$} & $\operatorname{Mn}(I V) / \operatorname{Cr}(I I I)$ & $\mathrm{pH}$ & Temp. \\
\hline & $\mathrm{mg}$ & $\mathrm{ml}$ & & $\mathrm{mg} / \mathrm{l}$ & $\mu \mathrm{mole} / \ell$ & & & ${ }^{\circ} \mathrm{C}$ \\
\hline \multirow[t]{2}{*}{$\mathrm{a}-\mathrm{MnO}_{2}$} & 200 & 800 & $\begin{array}{l}2.5 \times 10^{-4} \mathrm{~m} \mathrm{KCl} \\
10 \times 10^{-4} \mathrm{~m} \mathrm{MgCl}_{2} \\
50 \times 10^{-4} \mathrm{~m} \mathrm{CaCl}_{2}\end{array}$ & 250 & 24.0 & 98 & 5.5 & 29 \\
\hline & & & $\begin{array}{c}5 \mu \mathrm{g} / \mathrm{ml} \mathrm{Mn}, 3 \mu g / \mathrm{ml} \mathrm{Fe}, \\
1 \mu \mathrm{g} / \mathrm{ml} \mathrm{Al} \text { and } \mathrm{Zn}, \\
0.5 \mu \mathrm{g} / \mathrm{ml} \mathrm{Cu} \text {, } \\
0.1 \mu \mathrm{g} / \mathrm{ml} \mathrm{Ni}, \mathrm{Cd} \text {, and } \mathrm{Co}\end{array}$ & & & & & \\
\hline $\mathrm{B}-\mathrm{MnO}_{2}$ & 200 & 800 & $10^{-3} \mathrm{H} \mathrm{NaClO}_{4}$ & 250 & 24.0 & 115 & 5.5 & 30 \\
\hline $\mathrm{E}-\mathrm{MnO}_{2}$ & 1000 & 800 & $0.1 \mathrm{H} \mathrm{HClO}_{4}$ & 1250 & 481 & 29 & $1.0 * *$ & 25 \\
\hline$E-\mathrm{MnO}_{2}$ & 1000 & 800 & $10^{-3} \mathrm{M} \mathrm{NaClO}_{4}$ & 1250 & 601 & 23 & 8.0 & 26 \\
\hline
\end{tabular}

$* \mathrm{MnO}_{2}$ hydrosonically dispersed

$* * \mathrm{pH}$ stat not used

$* * \dot{*} \mathrm{Cr}(\mathrm{III})$ in excess 
experiments in which $\mathrm{Cr}$ (III) was in excess, the $\mathrm{pH}$ stat was not used and a typical kinetic run consisted of the following. The $\operatorname{Cr}$ (III) solution was measured into the reaction vessel and the $\mathrm{pH}$ adjusted (see Table 8 for $\mathrm{Cr}$ (III) concentrations and $\mathrm{pH}$ levels). The reaction vessel was placed in a constant temperature bath and allowed to reach thermal equilibrium (see Table 8 for temperatures). At time zero a measured volume of a $1000 \mathrm{mg} / \ell \delta-\mathrm{MnO}_{2}$ suspension in deionized water was added to achieve the desired initial $\mathrm{MnO}_{2}$ concentration (sec Table 8). At periodic intervals the suspension was sampled, filtered through $0.2 \mu \mathrm{m}$ membrane filters, and analyzed for Mn(II) by AAS.

\section{Kinetics of $\mathrm{Cr}$ Oxidation by $\delta-\mathrm{MnO}_{2}$ in the Presence}

of Fulvic Acid and the Kinetics of $\mathrm{Cr}$ and $\mathrm{Mn}$

Reduction by Fulvic Acid

A summary of the reaction conditions for experiments on the kinetics of $\mathrm{Cr}$ oxidation by $\delta-\mathrm{MnO}_{2}$ i.n the presence of fulvic acid and the kinetics of $\mathrm{Cr}$ and $\mathrm{Mn}$ reduction by fulvic acid is given in Table 9. A typical kinet1c run consisted of the following. Fulvic acid solution was added to the reaction vessel and the $\mathrm{pH}$ was adjusted to the dcsired level (see Table 9 for fulvic arid concentrations and $\mathrm{pH}$ levels). If the experiment called for $\delta-\mathrm{MnO}_{2}$ it was weighed out and added to the fulvic acid solution followed by mixing (see Table 9 for $\mathrm{MnO}_{2}$ concentrations used). At time zero $\operatorname{Cr}$ (III) or $\operatorname{Cr}(\mathrm{VI})$ solution was added to give the desired intial $\mathrm{Cr}$ concentration (see Table 9). At periodic intervals the solution was sampled, filtered through 0.2 um membrane filters if necessary, and analyzed for $\operatorname{Cr}(V I)$ or $M(I I)$. For the experiment involving moist Hagerstown silt loam, deionized water was used in place of fulvic acid solution and no $\mathrm{pH}$ adjustment was done. 
Table 9. Summary of reaction conditions for experiments on the kinetics of $C r$ oxidation in the presence of fulvic acid and the kinetics of $\mathrm{Cr}$ and $\mathrm{Mn}$ reduction by fulvic acid.

\begin{tabular}{|c|c|c|c|c|c|c|c|c|}
\hline $\begin{array}{l}\text { Soil or } \mathrm{MnO}_{2} \\
\text { Amount }\end{array}$ & $\begin{array}{l}\text { Fulvic Acid } \\
\text { Amount }\end{array}$ & $\begin{array}{l}\text { Solution } \\
\text { Volume }\end{array}$ & $\begin{array}{c}{[\mathrm{Soil}]} \\
\text { or } \\
{\left[\mathrm{MnO}_{2}\right]}\end{array}$ & [Fulvic Acid] & {$[\mathrm{Cr}(\mathrm{VI})]_{0}$} & {$[\operatorname{Cr}(I I I)]_{0}$} & $\mathrm{pH}$ & Temp. \\
\hline & & $\mathrm{ml}$ & & & \multicolumn{2}{|c|}{$-----\mu \mathrm{mole} / \ell-\cdots$} & & ${ }^{\circ} \mathrm{C}$ \\
\hline $\begin{array}{l}40 \mathrm{~g} \text { moist } \\
\text { llagerstown } \\
\text { silt loam }\end{array}$ & -- & 200 & $200 \mathrm{~g} / \mathrm{l}$ & -- & 96.2 & -- & 5.0 & 25 \\
\hline$\cdot \quad--$ & $\begin{array}{l}90 \mathrm{ml} 944 \mathrm{mg} / \mathrm{l} \\
\text { soil fulvic acid }\end{array}$ & 100 & -- & $850 \mathrm{mg} / \mathrm{l}$ & 96.2 & -- & 1.0 & 25 \\
\hline-- & $\begin{array}{l}90 \mathrm{ml} 944 \mathrm{mg} / \mathrm{l} \\
\text { soil fulvic acid }\end{array}$ & 100 & -- & $850 \mathrm{mg} / \mathrm{l}$ & 96.2 & -- & 5.5 & 25 \\
\hline-- & $\begin{array}{l}90 \mathrm{ml} 944 \mathrm{mg} / \ell \\
\text { soil fulvic acid }\end{array}$ & 100 & -- & $850 \mathrm{mg} / \mathrm{l}$ & 96.2 & -- & 5.5 & 50 \\
\hline-- & $\begin{array}{l}90 \mathrm{~m} .12 .4 \mathrm{~g} / \mathrm{l} \\
\text { leather dust } \\
\text { fulvic acid }\end{array}$ & 100 & -- & $11.2 \mathrm{~g} / \mathrm{l}$ & 96.2 & -- & 1.0 & 25 \\
\hline-- & $\begin{array}{l}90 \mathrm{ml} 12.4 \mathrm{~g} / \mathrm{l} \\
\text { leather dust } \\
\text { fulvic acid }\end{array}$ & 100 & -- & $11.2 \mathrm{~g} / \mathrm{l}$ & 96.2 & -- & 5.5 & 25 \\
\hline-- & $\begin{array}{l}90 \mathrm{ml} 12.4 \mathrm{~g} / \mathrm{l} \\
\text { leather dust } \\
\text { fulvic acid }\end{array}$ & 100 & -- & $1.1 .2 \mathrm{~g} / \mathrm{l}$ & 96.2 & -- & 5.5 & 50 \\
\hline
\end{tabular}


Table 9 (Continued).

\begin{tabular}{|c|c|c|c|c|c|c|c|c|}
\hline $\begin{array}{l}\text { Soil or } \mathrm{MnO}_{2} \\
\text { Amount }\end{array}$ & $\begin{array}{l}\text { Fulvic Acid } \\
\text { Amount }\end{array}$ & $\begin{array}{l}\text { Solution } \\
\text { Volume }\end{array}$ & $\begin{array}{l}{[\text { Soil }]} \\
\text { or } \\
{\left[\mathrm{MnO}_{e}\right]}\end{array}$ & [Fulvic Acid] & {$[\mathrm{Cr}(\mathrm{VI})]_{2}$} & {$[\operatorname{Cr}(\operatorname{III})]_{0}$} & $\mathrm{pH}$ & Temp. \\
\hline & & $\mathrm{m} 1$ & & & \multicolumn{2}{|c|}{ - } & & ${ }^{\circ} \mathrm{C}$ \\
\hline $100 \mathrm{mg} \delta-\mathrm{MnO}_{2}$ & $\begin{array}{l}200 \mathrm{ml} 12 . \dot{4} \mathrm{~s} / \mathrm{l} \\
\text { leather dust } \\
\text { fulicic acid }\end{array}$ & 200 & $500 \mathrm{ng} / \ell$ & $12.4 \mathrm{~g} / \mathrm{l}$ & $\dot{-}$ & 96.2 & 7.0 & 25 \\
\hline $100 \mathrm{mg} \delta-\mathrm{MnO}_{2}$ & $\begin{array}{l}200 \mathrm{ml} 12.4 \mathrm{~g} / \mathrm{l} \\
\text { lea=her dust } \\
\text { fulvic acid }\end{array}$ & 200 & $500 \mathrm{mg} / \ell$ & $12.4 \mathrm{~g} / \mathrm{l}$ & -- & -- & 5.5 & 25 \\
\hline
\end{tabular}




\section{RESULTS AND DISCUSSION}

\section{Plutonium Experiments}

\section{Chemical Fractionation of Soil Pu}

The $\mathrm{Pu}$ extracted with $\mathrm{Na}_{4} \mathrm{P}_{2} \mathrm{O}_{7}, \mathrm{NaOCl}, \mathrm{H}_{2} \mathrm{O}_{2}, \mathrm{NH}_{2} \mathrm{OH} \cdot \mathrm{HCl}$, or $\mathrm{DCB}$ from the Area $11 \mathrm{C}$ soil samples is listed in Table 10 along with coefficients of variation for duplicate extractions and analysis. The wide range in variances is a reflection of the non-uniform distribution of $\mathrm{Pu}$ in NTS soils, the error in sampling from the storage bottle, and the difficulty in precisely replicating trace level analyses.

Bremner and Lees (1948) originally discovered that $\mathrm{Na}_{4} \mathrm{P}_{2} \mathrm{O}$, was able to extract large amounts of soil organic matter although extractions were not $100 \%$ complete. Although NTS soils are expected to be relatively low in organic matter, $\mathrm{Na}_{4} \mathrm{P}_{2} \mathrm{O}_{7}$ was included in this study to extract $\mathrm{Pu}$ associated with the small amount of organic matter present. However, pyrophosphate anions are excellent complexers of metal ions, so any Pu sorbed to the surfaces of any soil component, organic or inorganic, will be desorbed by the pyrophosphate if the binding strength of Pu to pyrophosphate is stronger than the binding strength of $\mathrm{Pu}$ to the soil. Thus, pyrophosphate may not be selective for organo-Pu complexes.

The results in Table 10 indicate that essentially all of the pyrophosphate extractable Pu was Pu(IV). This is not surprising, since any $\mathrm{Pu}$ associated with the extracted organic matter would be expected to be in a reduced state. Also, any $\mathrm{Pu}(\mathrm{V} / \mathrm{VI})$ sorbed to mineral components could be reduced by the extracted organic matter during desorption and complexation by the pyrophosphate. The level of $\mathrm{Pu}$ extracted with pyrophosphate amounted to only a few percent of the total soil Pu (Table 4). The total soil yu measurements listed in Table 4 are in terms of $\mathrm{nCi} / \mathrm{g}$. 
Table 10. Plutonium extracted from a soil sample from Area 11C (NTS) using various extracting reagents.

\begin{tabular}{|c|c|c|c|c|c|}
\hline \multicolumn{2}{|r|}{ Extractant } & Valence & Valence Method & ${ }^{239} \mathrm{Pu}$ & C.V. \\
\hline \multirow{3}{*}{\multicolumn{2}{|c|}{$\begin{array}{c}0.1 \mathrm{M} \mathrm{Na}{ }_{4} \mathrm{P}_{2} \mathrm{O}_{7} \\
"\end{array}$}} & & & $\mathrm{nCi} / \mathrm{cm}^{3}$ & $\%$ \\
\hline & & IV & $\operatorname{PrF}_{3}$-TTA-xylene & 34.3 & 42 \\
\hline & & a11 & $\mathrm{NH}_{2} \mathrm{OH} \cdot \mathrm{HCl}-\mathrm{PrF}_{3}-\mathrm{TTA}-\mathrm{xy}$ lene & 40.2 & 25 \\
\hline \multirow[t]{6}{*}{$\mathrm{pH}$} & $9.5,5.25 \% \mathrm{NaOCl}$ & IV & TTA-xylene & 0.08 & 53 \\
\hline & " & $V+V I$ & $\mathrm{Ca}\left(\mathrm{NO}_{3}\right) 2^{\text {-hexone }}$ & 69.2 & 5.7 \\
\hline & " & a11 & $\mathrm{NH}_{2} \mathrm{OH} \cdot \mathrm{HCl}-\mathrm{PrF}_{3}-\mathrm{TTA}-\mathrm{xylene}$ & 69.7 & 14 \\
\hline & $\mathrm{pH} 7,10 \% \mathrm{H}_{2} \mathrm{O}_{2}$ & IV & TTA-xylene & 0.49 & 126 \\
\hline & $"$ & $V+V I$ & $\mathrm{Ca}\left(\mathrm{NO}_{3}\right)_{2}$-hexone & 0.10 & 64 \\
\hline & $"$ & all & $\mathrm{NH}_{2} \mathrm{OH} \cdot \mathrm{HCl}-\mathrm{PrF}_{3}-\mathrm{TTA}-\mathrm{xylene}$ & 0.14 & 71 \\
\hline \multirow[t]{4}{*}{$\mathrm{pH} 2$} & $2,0.1 \mathrm{M} \mathrm{NH}_{2} \mathrm{OH} \cdot \mathrm{HCl}$ & IV & TTA-xylene & 0.23 & $-\infty$ \\
\hline & $"$ & $I I I+I V$ & $\operatorname{PrF}_{3}$-TTA-xylene & 0.35 & -- \\
\hline & $\mathrm{DCB}$ & IV & $\operatorname{PrF}_{3}-\mathrm{TTA}-\mathrm{xylene}$ & 41.1 & 36 \\
\hline & $" 1$ & $I I I+I V$ & $\mathrm{PrF}_{3}$-TTA-xylente & 46.4 & 37 \\
\hline
\end{tabular}

$\varlimsup_{\mathrm{NaNO}_{3}}$ omitted from procedure 
However, soil volume measurements were used in the fractionation experiments. To convert total soil $\mathrm{Pu}$ in $\mathrm{nCi} / \mathrm{g}$ to $\mathrm{nCi} / \mathrm{cm}^{3}$ the values are. multiplied by $1.3 \mathrm{~g} / \mathrm{cm}^{3}$, the average bulk density of soil. When this was done for the sample from Area $11 \mathrm{C}$ used in the fractionation experiments, an estimated value of $976 \mathrm{nCi} / \mathrm{cm}^{3}$ for total soil Pu was obtained. Thus, very little of the $\mathrm{Pu}$ in this sample was associated with organic matter or desorbable from mineral components with pyrophosphate.

Sodium hypochlorite was originally proposed by Anderson (1963) as a good oxidizing agent for destroying organic matter from soil and Lavkulich and Wiens (1970) showed that $\mathrm{NaOCl}$ was more efficient than $\mathrm{H}_{2} \mathrm{O}_{2}$ in destroying soil organic matter and less destructive of mineral constituents. Therefore, it was included in this study as an extractant for soil Pu associated with organic matter. Because NaOCI can oxidize $\mathrm{Pu}(\mathrm{III} / \mathrm{IV})$ to $\mathrm{Pu}(\mathrm{V} / \mathrm{VI})$, any $\mathrm{Pu}$ associated with the soil organic matter would likely be oxidized as the organic matter was destroyed and would more readily remain in solution. Surface sorbed Pu would likely be oxidized as'well. The results in Table 10 indicate that NaOCl extracLable $\mathrm{Pu}$ was only slightly greater than pyrophosphate extractable pu. This tends to confirm the conclusion that only a very small fraction of the soll Pu was assoclated with the soil organic matter or was surtace sorbed, and therefore potentially oxidizable. As expected virtually all of the Pu in the NaOCI extracts was oxidized.

Hydrogen peroxide was also tried as an extractant for Pu associated with soil organic matter or potentially oxidizable Pu sorbed to soil surfaces. At acid $\mathrm{pH}$ levels besides oxidizing organic matter, $\mathrm{H}_{2} \mathrm{O}_{2}$ will reduce manganese oxides (Taylor and McKenzie, 1966) and $\mathrm{Pu}(\mathrm{V} / \mathrm{VI}$ ) (Cleveland, 1970). At neutral to alkaline $\mathrm{pH}$ levels, $\mathrm{H}_{2} \mathrm{O}_{2}$ will not 
reduce manganese oxides and can oxidize $\mathrm{Pu}($ III/IV) (Cleveland, 1970). Thus, by using a neutral $10 \% \mathrm{H}_{2} \mathrm{O}_{2}$ solution it was hoped that soil organic matter could be destroyed releasing any associated $\mathrm{Pu}$ which would then be oxidized and more readily remain in solution. However, the results in Table 10 show that $\mathrm{H}_{2} \mathrm{O}_{2}$ was not a good extracting agent for Pu. This probably reflects the inability of $\mathrm{H}_{2} \mathrm{O}_{2}$ to oxidize the $\mathrm{Pu}$ despite the predicted results, or because metal ions readily cause the catalytic decomposition of $\mathrm{H}_{2} \mathrm{O}_{2}$ al higler $\mathrm{pH}$ levels, the $\mathrm{H}_{2} \mathrm{O}_{2}$ may have been destroyed before it had a chance to be an effective oxidizing agent. Chao (1972) origina11y shnwer that $\mathrm{NH}_{2} \mathrm{OH} \cdot \mathrm{HCl}$ was an effective reducing agent for soil manganese oxides, thus releasing any associated metal lons, and that it did not readily reduce iron. Thus, one could distinguish between metal ions occluded by manganese or iron oxides. Any metal ions sorbed to the surface of iron oxides would likely be extracted, however, since the reagent is not perfectly selective. The results in Table 10 suggest that very l1ttle $\mathrm{Pu}$ was associated with the manganese oxide minerals in the soil sample. The $\mathrm{NH}_{2} \mathrm{OH} \cdot \mathrm{HCl}$ was apparently unable to extract surface sorbed $\mathrm{Pu}$ that $\mathrm{Na}_{4} \mathrm{P}_{2} \mathrm{O}_{7}$ and $\mathrm{NaOCl}$ were able to extract. It is not surprising to find little Pu associated with the manganese oxide minerals. At the high $\mathrm{pH}$ level.s nf the NTS soils and with sufficient carbonate anions present the formation of $\mathrm{PuO}_{2} \mathrm{CO}_{3} \mathrm{OH}^{-}$ ions is likely. Since these ions are negatively charged, they will be repelled by the surfaces of the minerals which have a net negative charge at the pH levels typical of NTS soils. Existing as the cations $\mathrm{PuO}_{2}^{+}$or $\mathrm{PuO}_{2}^{2+}$, oxidized $\mathrm{Pu}$ could be sorbed to manganese oxide minerals. This is the basis for using $\mathrm{MnO}_{2}$ cartridges as scavengers for $\mathrm{Pu}$ in water (Wong et al., 1978). 
The dithionite-citrate-bicarbonate procedure of Mehra and Jackson (1960) was used to remove free iron oxides in the soil sample from Area 11C. Sodium dithionite will reduce $\mathrm{Fe}$ (III) to $\mathrm{Fe}$ (II) which is then complexed by citrate ions and kept in solution. Buffering is provided by bicarbonate. Any metal ions associated with the iron oxides are also released and complexed by the citrate ions. This reagent is non-selective, however, in that manganese oxides are also reduced and the citrate and bicarbonate can extract organic matter. Thus, this reagent should extract $\mathrm{Pu}$ associated with organic matter, Pu sorbed to and occluded by iron and manganese oxides, and perhaps any non-crystalline $\mathrm{Pu}$ in the soil. The results in Table 10 demonstrate that DCB extracted practically the same amount of $\mathrm{Pu}$ as did the $\mathrm{Na}_{4} \mathrm{P}_{2} \mathrm{O}_{7}$. Thus, there seems to have been no occluded $\mathrm{Pu}$ in this soil sample and all of the extractable $\mathrm{Pu}$ is probably surface sorbed. Virtually all of the DCB extractable Pu was $\mathrm{Pu}(\mathrm{IV})$ which is not surprising, since the reducing nature of the reagent would keep the $\mathrm{Pu}$ in a reduced state.

The reasonable agreement between the extractable $\mathrm{Pu}$ values for the $\mathrm{Na}{ }_{4} \mathrm{P}_{2} \mathrm{O}_{7}$, NaOC1, and $\mathrm{DCB}$ reagents indicates that the extractable $\mathrm{Pu}$ could be associated with organic matter, sorbed to mineral surfaces, or both since the nonselectivity of the reagents does not allow one to distinguish between the potential sources. However, it is clear that only a very small fraction of the total soil Pu. content would be readily bioavailable which is in keeping with what is already known about Pu in these soils (White and Dunaway (eds.), 1975, 1976, 1977a, 1977b, and 1978). Tamura (1975) has shown that Pu in NTS soils is extremely stable to attack from $\mathrm{HNO}_{3}$ and cltrate and these latest results are in agreement with this observation. This unusual stability appears to be 
kinetic rather than thermodynamic, however, since $\mathrm{PuO}_{2}$ should. be unstable in all the reagents used. Therefore, the time of extraction is an important experimental variable.

\section{Extraction of Soil Pu(V/VI)}

To see whether any $\mathrm{Pu}(\mathrm{V} / \mathrm{VI})$ species existed in the soil sample from Area $11 \mathrm{C}$, extractions were carried out using $\mathrm{KH}_{2} \mathrm{PO}_{4}, \mathrm{Na}_{2} \mathrm{CO}_{3}, \mathrm{Na}_{4} \mathrm{P}_{2} \mathrm{O}_{7}$, and $\mathrm{Na}_{4} \mathrm{P}_{2} \mathrm{O}_{7}+\mathrm{Na}_{2} \mathrm{CO}_{3}$ and the results are 1isted in Table 11 . Potassium phosphate was chosen as an extractant because Bartlett and James (1979) had already demonstrated that it was a good extractant for $\operatorname{Cr}$ (VI) species, so it was presumed that it would also be a good extractant for $\mathrm{Pu}(\mathrm{V} / \mathrm{VI})$. It did extract a small amount of $\mathrm{Pu}(\mathrm{V} / \mathrm{VI})$, but it also extracted more $\mathrm{Pu}(\mathrm{IV})$ than $\mathrm{Pu}(\mathrm{V} / \mathrm{VI})$. There is a discrepancy between the results obtained with the TTA-xylene/Ca $\left(\mathrm{NO}_{3}\right)_{2}$-hexone valence state separation methods and the results obtained with the $\operatorname{PrF}_{3}$-TTAxylene/ $\mathrm{NH}_{2} \mathrm{OH} \cdot \mathrm{HCl}-\mathrm{PrF}_{3}-\mathrm{TH}^{\prime \prime} \mathrm{A}-\mathrm{xyl}$ ene methods. The TTA-xylene/Ca $\left(\mathrm{NO}_{3}\right)_{2}-$ hexone methods yielded less $P_{u}(I V)$ and more $P_{1}(V / V T)$ than did the methods using $\operatorname{PrF}_{3}$ coprecipitation. The total amount of $\mathrm{Pu}$ extracted was the same for both methods. It appears that the TTA-xylene solution failed to completely extract the $\mathrm{Pu}(\mathrm{IV})$, so that it was then extracted by the $\mathrm{Ca}\left(\mathrm{NO}_{3}\right)_{2}$-hexone solution and was counted as $\mathrm{Pu}(\mathrm{V} / \mathrm{VI})$. By using a $\mathrm{PrF}_{3}$ coprecipitation step all of the $\mathrm{Pu}(\mathrm{IV})$ that could be precipitated was removed from solution resulting in mnre reliable resulte. For this reason the $\mathrm{PrF}_{3}-\mathrm{TTA}-\mathrm{xylene} / \mathrm{NH}_{2} \mathrm{OH} \cdot \mathrm{HC1}-\mathrm{PrF}_{3}-\mathrm{TTA}-\mathrm{xylene}$ methods are thought to be the more reliable methods.

Sodium carbonate was selected as an extractant because carbonate solutions are excellent solvents for uranium (U) minerals (Garrels and Christ, 1965), and it was assumed that $\mathrm{Pu}$ is enough like $\mathrm{U}$ to make it 
Table 11. Plutonium extracted from a soil sample from Area 11C (NTS) using various extracting reagents.

\begin{tabular}{|c|c|c|c|c|c|}
\hline \multirow[b]{2}{*}{ Extractant } & \multirow[b]{2}{*}{ Valence Method } & \multicolumn{4}{|c|}{${ }^{239} \mathrm{Pu}$} \\
\hline & & IV & IV & $V+V I$ & Total \\
\hline & & \multicolumn{4}{|c|}{$\ldots-n \mathrm{n} i / \mathrm{cm}^{3}-\ldots$} \\
\hline \multirow{2}{*}{$0.01 \mathrm{M} \mathrm{KH}_{2} \mathrm{PO}_{4}$} & TTA-xylene $/ \mathrm{Ca}\left(\mathrm{NO}_{3}\right) 2^{- \text {hexone }}$ & 0.139 & -- & 0.143 & 0.282 \\
\hline & $\begin{array}{c}\mathrm{PrF}_{3}-\mathrm{TTA}-\mathrm{xylene} / \mathrm{NH}_{2} \mathrm{OH} \cdot \mathrm{HCl}- \\
\mathrm{PrF}_{3}-\mathrm{TTA}-\mathrm{xylene}\end{array}$ & -- & 0.201 & 0.081 & 0.282 \\
\hline \multirow{2}{*}{$\begin{array}{c}0.2 \mathrm{M} \mathrm{Na}_{2} \mathrm{CO}_{3} \\
.\end{array}$} & TTA-xylene/Ca $\left(\mathrm{NO}_{3}\right)_{2}$-hexone & 6.78 & -- & 3.17 & 9.95 \\
\hline & $\begin{array}{c}\mathrm{PrF}_{3}-\mathrm{TTA}-\mathrm{xylene} / \mathrm{NH}_{2} \mathrm{OH} \cdot \mathrm{HCl}- \\
\operatorname{PrF}_{3}-\mathrm{TTA}-\mathrm{xylene}\end{array}$ & -- & 7.27 & 1.25 & 8.52 \\
\hline $0.1 \mathrm{M} \cdot \mathrm{Na}_{4}{ }^{\mathrm{P}}{ }_{2} \mathrm{O}_{7}$ & $\begin{array}{c}\mathrm{PrF}_{3}-\mathrm{TTA}-\mathrm{xylene} / \mathrm{NH}_{2} \mathrm{OH} \cdot \mathrm{HCl}- \\
\operatorname{PrF}{ }_{3}-\mathrm{TTA}-x y \text { lene }\end{array}$ & -- & 38.5 & 3.32 & 41.8 \\
\hline $0.05 \mathrm{M} \mathrm{Na}_{4} \mathrm{P}_{2} \mathrm{C}_{7}+0.1 \mathrm{M} \mathrm{Na}_{2} \mathrm{CO}_{3}$ & $\begin{array}{c}\mathrm{PrF}_{3}-\mathrm{TTA}_{3}-\mathrm{xylene} / \mathrm{NH}_{2} \mathrm{OH} \cdot \mathrm{HCl}- \\
\text { PrF }-\mathrm{TTA}-x y \text { lene }\end{array}$ & -- & 19.2 & 2.92 & 22.1 \\
\hline
\end{tabular}


worthwhile to try a carbonate extracting solution. Also, carbonate is one of the constituents of the hydroxy-carbonate $\mathrm{Pu}$ species, $\mathrm{PuO}_{2} \mathrm{CO}_{3} \mathrm{OH}^{-}$, and the high pH NTS soils contain appreciable levels of carbonate (Leavitt, 1970). Sodium carbonate was able to extract a significant amount of $\mathrm{Pu}$ with most of that being $\mathrm{Pu}(\mathrm{IV})$. However, an appreciable amount of $\mathrm{Pu}(\mathrm{V} / \mathrm{VI})$ was also extracted. Again, it appears that the TTAxylene method alone failed to extract all of the Pu(IV) which allowed the remainder to be extracted with the $\mathrm{Pu}(\mathrm{V} / \mathrm{VI})$ by the $\mathrm{Ca}\left(\mathrm{NO}_{3}\right)_{2}$-hexone. However, there is a discrepancy between the total Pu results obtained with the two sets of methods. It appears that the $\mathrm{Pu}(\mathrm{V} / \mathrm{VI})$ results using the $\mathrm{NH}_{2} \mathrm{OH} \cdot \mathrm{HCl}-\mathrm{PrF}_{3}-\mathrm{TTA}-\mathrm{xy}$ lene methods may have been too low. A second $\mathrm{PrF}_{3}$-TTA-xylene extrartion after the firet yielded ncgligible amounts of $\mathrm{Pu}$. After adding the $\mathrm{NH}_{2} \mathrm{OH} \cdot \mathrm{HCl}$ reducing agent, $\mathrm{Pu}$ was extracted with the $\mathrm{PrF}_{3}$-TTA-xylene methods, so it seems that the remaining $P_{u}$ was definitely $\mathrm{Pu}(\mathrm{V} / \mathrm{VI})$, but for some reason extraction was incomplete in this case.

Another sodium pyrophosphate extraction was carried out followed by a complere Pu valence state separation scheme. Mostly Pu(IV) was found, but somewhat surprisingly, some $\mathrm{Pu}(\mathrm{V} / \mathrm{VI})$ was also found. This was unexpected, since the organic matter extracted by the pyrophosphate was expected to keep the $\mathrm{Pu}$ in a reduced state. Perhaps the amount of organic matter extracted was too low and the rate of reduction too slow lu dssure all Pu(IV).

A mixed $\mathrm{Na}_{2} \mathrm{CO}_{3}+\mathrm{Na}_{4} \mathrm{P}_{2} \mathrm{O}_{7}$ extractant was also tried with each salt at half the concentration as the individual extractants. Tnterestingly, at half the concentration of $\mathrm{Na}_{4} \mathrm{P}_{2} \mathrm{O}_{7}$, half as much $\mathrm{Pu}$ (IV) was extracted 
by the mixed extractant as compared to $\mathrm{Na}_{4} \mathrm{P}_{2} \mathrm{O}_{7}$ alone, but the amount of $\mathrm{Pu}(\mathrm{V} / \mathrm{VI})$ extracted was about the same with the two extractants.

At this point it is necessary to discuss what was happening during the extractions. There are several possibilities. The extracted amounts of each valence state may represent the actual valence state distribution in the soil, but this does not seem likely, since there was ample opportunity for the extracted $\mathrm{Pu}$ to react with soil components and added reagents. All of the extractable $\mathrm{Pu}$ might have been $\mathrm{Pu}(\mathrm{V} / \mathrm{VI})$ in the soil at one time, but most of it became reduced during storage of the soil or during extraction. Equally or more likely, the extractable $\mathrm{Pu}$ might have been all $\mathrm{Pu}(\mathrm{IV})$ initially and during the extraction the dissolved $\mathrm{Pu}(\mathrm{IV})$ reacted with manganese oxide minerals yielding $\mathrm{Pu}(\mathrm{V} / \mathrm{VI})$. Also highly likely is that both oxidation and reduction were occurring during extraction. The extractions performed do not allow one to distinguish between the various possibilities unequivocally. Additional experiments would be necessary. One experiment was performed in which the effect of extraction time on $\mathrm{Na}_{2} \mathrm{CO}_{3}$ extraction of $\mathrm{Pu}$ was studied in order to test the possibility of oxidation during extraction and the results are listed in Table 12. There was a relatively greater increase in the amount of $\mathrm{Pu}(\mathrm{V} / \mathrm{VI})$ extracted after a longer extraction time as compared to the increase in the amount of $\mathrm{Pu}($ III/IV) extracted. These results indicate that additional extraction time was needed to oxidize the $\mathrm{Pu}$ because $\mathrm{Pu}(\mathrm{V} / \mathrm{VI})$ should be weakly held by soil and readily extractable regardless of extraction time. Whatever the case, $\mathrm{Pu}(\mathrm{V} / \mathrm{VI})$ either exists or can readily be produced in Area 11 soils. 
Oxidation of Carbonate-Soluble Pu

To see whether oxidation of carbonate-soluble $\mathrm{Pu}$ could be enhanced, a sample of soil from Area $11 \mathrm{C}$ was incubated with a large excess of $\delta-\mathrm{MnO}_{2}$ before extraction with $\mathrm{Na}_{2} \mathrm{CO}_{3}$. The results of this experiment are shown in Table 13 along with the results from the $\mathrm{Na}_{2} \mathrm{CO}_{3}$ extraction alone for comparison. Virtually all of the extracted Pu was oxidized by the $\delta-\mathrm{MnO}_{2}$ and the incubation with $\delta-\mathrm{MnO}_{2}$ also increased the solubility of the Pu. It is not difficult to conceive of situations where carbonatebearing water coming into contact with $\mathrm{PuO}_{2}$ and $\mathrm{MnO}_{2}$ would lead to increased mobility of $\mathrm{Pu}$ in a localized environment. Tn order to further stabilize the $\mathrm{PuO}_{2}$ in the NTS soils, everything possible should be done to encourage revegetation nf cnntaminated areas. This would not only stabilize the soils against erosion, but also add more organic matter to the soil to help keep the $\mathrm{Pu}$ in a reduced state. If any contaminated areas need to be filled in, materials containing ferromagnesian minerals should be used with a minimum of manganese oxide minerals present.

\section{Extraction of Soil Am}

Some results for the extraction of ${ }^{241} \mathrm{Am}$ are presented in Table 14. Sodium pyrophosphate and DCB were the two best extractants. Unlike the case with $\mathrm{Pu}$, NaOCl was a poor extractant for Am indicating Am is not readily oxidized in soils which is in keeping with what is known about the redox reactions of this element. As with $\mathrm{Pu}$, the amount of Am extracted was only a few percent of the total soil Am which was about $123 \mathrm{nCi} / \mathrm{Cm}^{3}$. 
Table 12. Effect of extraction time on $\mathrm{Na}_{2} \mathrm{CO}_{3}$ extractable $\mathrm{Pu}$ in a soil sample from Area 11C (NTS).

\begin{tabular}{|c|c|c|c|c|c|}
\hline \multirow[b]{2}{*}{ Extractant } & \multirow[b]{2}{*}{ Extraction } & \multirow[b]{2}{*}{ Time } & \multicolumn{3}{|c|}{$239 \mathrm{Pu}$} \\
\hline & & & $\operatorname{III}+\operatorname{IV*}$ & $V+V I * *$ & Total \\
\hline & & & - & $i / \mathrm{cm}^{3}-$ & --- \\
\hline $\mathrm{Na}_{2} \mathrm{CO}_{3}$ & $5 \mathrm{~min}$ & & 4.25 & 0.20 & 4.45 \\
\hline $\mathrm{Na}_{2} \mathrm{CO}_{3}$ & $1 \mathrm{hr}$ & - & 7.27 & 1.25 & 8.52 \\
\hline
\end{tabular}

$\star \operatorname{PrF}_{3}-\mathrm{TTA}-\mathrm{xy}$ lene

$* * \mathrm{NH}_{2} \mathrm{OH} \cdot \mathrm{HCl}-\mathrm{PrF}_{3}-\mathrm{TTA}-\mathrm{xylene}$

Table 13. Oxidation of $\mathrm{Na}_{2} \mathrm{CO}_{3}$ soluble $\mathrm{Pu}$ in a soil sample from Area $11 \mathrm{C}$ (NTS) , using $\delta-\mathrm{MrO}_{2}$.

\begin{tabular}{ccccr}
\hline & & & 239 \\
\cline { 3 - 4 } Sample & Extractant & $I I I+I V^{*}$ & $V+V I^{\frac{1}{*}}$ & Total \\
\cline { 3 - 5 } $11 \mathrm{C}-2$ & $\mathrm{Na}_{2} \mathrm{CO}_{3}$ & 7.27 & 1.25 & 8.52 \\
$11 \mathrm{C}-2+\delta-\mathrm{MnO}_{2}$ & $\mathrm{Na}_{2} \mathrm{CO}_{3}$ & 0.22 & 14.5 & 14.7
\end{tabular}

$\approx \mathrm{PrF}_{3}-\mathrm{TTA}-\mathrm{xylene}$

$\therefore * \mathrm{NH}_{2} \mathrm{OH} \cdot \mathrm{HCl}-\mathrm{PrF}_{3}-\mathrm{TTA}-\mathrm{xylene}$ 


\section{Chromium Experiments}

Chemical Fractionation of Soil Cr and Mn

The water content, $\mathrm{pH}$, and organic matter content of the Hagerstown and Murrill silt loam samples are shown in Table 15 . The water content increased with increasing organic matter content reflecting the excellent water-holding capacity of organic matter. The high $\mathrm{pH}$ of the Murrill soil was a result of lime added to the sludge during sludge processing at the treatment plant.

Sodium hydroxide is a good extractant for soi.1 organic matter (Stevensnn, 1.965): The humic and fulvic acid components of urgantc matter are soluble in $\mathrm{NaOH}$. Any $\mathrm{Cr}$ associated with humic and fulvic arfids would be extractcd as well. Decause of the high pH involved, the Cr would be expected to be insoluble, so in order to stay in solution it would have to be complexed by the organic acids. Results of $\mathrm{NaOH}$ extractions of the sludge used on the field plots and two of the soil samples are 1isted in Table 16. About $28 \%$ of the $\operatorname{Cr}$ in the sludge was soluble in strong base indicating a suhstantial amount of complcxation of $\mathrm{Cr}$ by organic matter, since this is a highly insoluble element. Significant amounts of $\mathrm{Cr}$ in the two soil samples were soluble in $\mathrm{NaOH}$, although the fraction of total Cr in the soil that was NaOH solutile was much less than the fraction of total $\mathrm{Cr}$ in sludge that was $\mathrm{NaOH}$ soluble. However, more $\mathrm{Cr}$ might have been associated with the organic matter than what the $\mathrm{NaOH}$ extracts indicated, since extraction of soil organic matter with $\mathrm{NaOH}$ is incomplete.

The results from the chemical fractionation of soil $\mathrm{Cr}_{1}$ are presented in Table 17. The order of extractants in terms of their ability to extract $\mathrm{Cr}$ was $\mathrm{NaOCl}>\mathrm{H}_{2} \mathrm{O}_{2}>\mathrm{Na}_{4} \mathrm{P}_{2} \mathrm{O}_{7}>\mathrm{NH}_{2} \mathrm{OH} \cdot \mathrm{HCl}$. All the extractants 
Table 14. Americium extracted from a soil sample from Area 11C (NTS) using various extracting reagents.

\begin{tabular}{cc}
\hline Extractant & $241_{\mathrm{Am}}$ \\
\hline $0.1 \mathrm{M} \mathrm{Na} 4_{4}{ }_{2} \mathrm{O}_{7}$ & $\mathrm{nCi} / \mathrm{cm}^{3}$ \\
$\mathrm{pH} 9.5,5.25 \% \mathrm{NaOC} 1$ & 10.05 \\
$\mathrm{pH} 2,0.1 \mathrm{M} \mathrm{NH}{ }_{2} \mathrm{OH} \cdot \mathrm{HCl}$ & 1.47 \\
$\mathrm{DCB}$ & 0.74 \\
\hline
\end{tabular}

Table 15. Water content $\left(\theta_{d_{w}}\right), \mathrm{pH}$, and organic matter (O.M.) content of collected Hagerstown silt loam and Murrill silt loam samples.

\begin{tabular}{lcccc}
\hline \multirow{2}{*}{ Soil Series } & Total & & & \\
& Sludge Treatment & $\theta_{\mathrm{dw}}$ & $\mathrm{pH}$ & $0 . \mathrm{M}$. \\
\hline Magerstown & 0 & $\%$ & & $\%$ \\
& 11.2 & 22.2 & 5.51 & 1.6 \\
& 22.4 & 24.1 & 5.52 & 2.1 \\
& 44.8 & 24.6 & 5.36 & 2.2 \\
Murrill & 89.6 & 25.4 & 5.98 & 2.2 \\
& & 27.6 & 7.17 & 2.4 \\
\hline
\end{tabular}


Table 16. Chromium in $0.5 \mathrm{M} \mathrm{NaOH}$ extractable organic matter from sludge and moist Hagerstown silt loam and Murri11 silt loam amended with sludge.

\begin{tabular}{ccc}
\hline Sample & $0.5 \mathrm{M} \mathrm{NaOH}$ Extractable Cr \\
\hline & $\mu \mathrm{g} / \mathrm{g}$ & $\%$ of lotal $\mathrm{Cr}$ \\
Sl.udge & 187.5 & 28.4 \\
$\begin{array}{l}\text { Hagerstown silt loam amended } \\
\text { with } 44.8 \mathrm{MT} / \mathrm{ha} \text { sludge }\end{array}$ & 2.8 & 3.4 \\
$\begin{array}{l}\text { Murrill silt loam amended } \\
\text { with } 89.6 \mathrm{MT} / \mathrm{ha} \text { sludge }\end{array}$ & 4.6 & - \\
\hline
\end{tabular}


Table 17. Chemical fractionation of soil $\mathrm{Cr}$.

\begin{tabular}{|c|c|c|c|c|c|c|c|c|c|c|c|c|c|c|}
\hline \multirow{4}{*}{ Soil Series } & \multirow{4}{*}{$\begin{array}{c}\begin{array}{c}\text { Total } \\
\text { Sludge } \\
\text { Treatment }\end{array} \\
\mathrm{M} \text { /ha }\end{array}$} & \multirow{3}{*}{\multicolumn{2}{|c|}{$\begin{array}{l}\mathrm{pH} 10 \\
0.1 \mathrm{M} \\
\mathrm{Na}_{4} \mathrm{P}_{2} \mathrm{O}_{7}^{* * \pi}\end{array}$}} & \multirow{3}{*}{\multicolumn{2}{|c|}{$\begin{array}{l}\mathrm{pH} 9.5 \\
5.25 \% \\
\mathrm{NaOCl} * *\end{array}$}} & \multirow{2}{*}{\multicolumn{4}{|c|}{$\begin{array}{l}\mathrm{pH} 2,0.1 \mathrm{M} \mathrm{NH} 2 \mathrm{OH} \cdot \mathrm{HCl}^{*} \\
\text { Soil/Solution Ratio }\end{array}$}} & \multicolumn{2}{|c|}{$\begin{array}{c}\mathrm{pH} 3,10 \% \\
\mathrm{H}_{2} \mathrm{O}_{2}^{* \star}\end{array}$} & \multicolumn{2}{|c|}{$\begin{array}{c}\mathrm{pH} 2,10 \% \\
\mathrm{H}_{2} \mathrm{O}_{2}{ }^{*}\end{array}$} & \multirow{3}{*}{ Total } \\
\hline & & & & & & & & & & \multicolumn{4}{|c|}{ Soil/Solution Ratio } & \\
\hline & & & & & & & 5 & 1: & & \multicolumn{2}{|c|}{$1: 5$} & \multicolumn{2}{|c|}{$1: 50$} & \\
\hline & & $\mu g / g$ & $\begin{array}{l}\% \text { of } \\
\text { Total }\end{array}$ & $\mu \mathrm{g} / \mathrm{g}$ & $\begin{array}{l}\% \text { of } \\
\text { Total }\end{array}$ & $\mu \mathrm{g} / \mathrm{g}$ & $\begin{array}{l}\text { \% of } \\
\text { Total }\end{array}$ & $\mu g / g$ & $\begin{array}{l}\% \text { of } \\
\text { Total }\end{array}$ & $\mu g / g$ & $\begin{array}{l}\% \text { of } \\
\text { Total }\end{array}$ & $\mu g / g$ & $\begin{array}{l}\text { \% of } \\
\text { Total }\end{array}$ & $\mu g / g$ \\
\hline \multirow[t]{4}{*}{ Hagerstown } & 0 & -- & - & 3.6 & 5.5 & 0.10 & 0.2 & 0.75 & 1.2 & 0.40 & 0.6 & 0.50 & 0.8 & 65 \\
\hline & 11.2 & 2.55 & 3.7 & 8.6 & 12.6 & 0.20 & 0.3 & 1.00 & 1.5 & 0.52 & 0.8 & 3.00 & 4.4 & 68 \\
\hline & 22.4 & 4.70 & 6.1 & 13.7 & 17.8 & 0.25 & 0.3 & 1.00 & 1.3 & 0.62 & 0.8 & 5.00 & 6.5 & 77 \\
\hline & 44.8 & 6.45 & 7.8 & 19.8 & 23.9 & 0.17 & 0.2 & 1.25 & 1.5 & 0.87 & 1.0 & 7.25 & 8.7 & 83 \\
\hline Hurrill & 89.6 & 6.45 & - & 18.0 & -- & 0.12 & -- & 1.50 & -- & 2.30 & -- & 8.75 & $-\dot{-}$ & -- \\
\hline Chrome & -- & 0.55 & 0.05 & 66 & 6.0 & 0.10 & 0.01 & -- & -- & 6.2 & 0.56 & -- & -- & 1100 \\
\hline
\end{tabular}

$* 1$ extraction

$* * 3$ extractions 
reflected the increase in $C_{r}$ in the Hagerstown and Murrill soils as a result of increasing sludge additions. The low amounts of $\mathrm{Cr}$ extracted by $\mathrm{NH}_{2} \mathrm{OH} \cdot \mathrm{HCl}$ are not surprising, since this extractant reduces manganese oxides and any $\mathrm{Cr}$ coming into contact with manganese oxides would be oxidized and leached out of the soil. The $\mathrm{Cr}$ that was extracted by the $\mathrm{NH}_{2} \mathrm{OH} \cdot \mathrm{HCl}$ was likely sorbed to other soil components and dissolved by the low $\mathrm{pH}$ of the extractant. The other extractants were able to extract or destroy soil organic matter and dissolve any associated Cr. Surface sorbed $\mathrm{Cr}$ was also undoubtedly extracted. It is unknown whether the small amount of $\mathrm{Cr}$ in the Chrome soil that was extracted with Nancl. or $\mathrm{H}_{2} \mathrm{O}_{2}$ actually represented organic matter $\mathrm{Cr}$ or inorganic $\mathrm{Cr}$ that was oxidized by the $\mathrm{NaOCl}$ or $\mathrm{H}_{2} \mathrm{O}_{2}$. In any rise the amnint extracted was a small fraction of the total reflecting the known high degree of resistance to weathering of chromite ore in surface environments.

Potassium phosphate extractions were run on all the collected soil samples to see if any $\operatorname{Cr}(\mathrm{VI})$ was present in any of the soils indicating that Ćr oxidation was taking place. However, no detectable $\operatorname{Cr}(\mathrm{VI})$ was found in any of the samples. This is not surprising for the Hagerstown and Murrill samples where the added $\mathrm{Cr}$ came from an organic source. The organic matter would be expected to keep the $\mathrm{Cr}$ in a reduced state. The $\mathrm{Cr}$ in the Chrome soil is inorganic, however, existing as the mineral chromite. At first it might be expected that this Sor wnuld he nxidizable by mangantest uxldes. Th1s would mean that chromite would be a soluble mineral and that $\mathrm{Cr}$ would be a geochemically mobile element. However, this conclusion contrasts sharply with reality. Chromite is very resistant to weathering and thus $\mathrm{Cr}$ is considered to be a geochemically immobile element. The answer may lie in the chemical formula of the 
mineral, $\mathrm{FeCr}_{2} \mathrm{O}_{4} \cdot$ Both iron and chromium are in a reduced state in this mineral and this might lend extra resistance to weathering to -the . mineral. The reduced $\mathrm{Fe}$ might help keep the $\mathrm{Cr}$ in a reduced state and thus the rate of oxidation is so slow as to be negligible.

The various extracts were also analyzed for $\mathrm{Mn}$ and these results are presented in Table 18. The most remarkable thing about this data is the very low $\mathrm{NH}_{2} \mathrm{OH} \cdot \mathrm{HCl}$ and $\mathrm{H}_{2} \mathrm{O}_{2}$ extractable $\mathrm{Mn}$ in the Chrome soil as compared to the Hagerstown and Murrill soils. The lack of reducible Mn in the Chrome soil may also contribute to the high resistance to weathering of chromite ore, since little manganese oxide is present to oxidize the $\mathrm{Cr}$. Perhaps the manganese oxide is depleted by the reducing action of the chromite.

As the results in Table 17 already. indicated, NaOCl was able to reflect the increased $\mathrm{Cr}$ content of the soils as a result of sludge addition. This reagent shows promise in being able to distinguish between added $C r$ that is readily oxidizable and natural soil $C r$ which is not as readily oxidizable, since the amount of NaOCl extractable Cr found in the sample from the plot with no sludge was only about $5 \%$ of the total. But the question remains as to how well this extractant can account for all of the added $\mathrm{Cr}$. This question is answered in Tables 19 and 20. In Table 19 the amount of $\mathrm{Cr}$ added as determined by total analysis and NaOCl extraction of the moist Hagerstown samples is presented. These results were obtained by subtracting the results for the plot not recelving any sludge from the results for the plots amended with sludge. The results indicate that the NaOC1 extraction accounted for the added $C r$ fairly well. However, the moist samples were only grab samples from one set of plots. To obtain a more reliable sampling, 
Table 18. Chemical fractionazion of soll Ma.

\begin{tabular}{|c|c|c|c|c|c|c|c|c|c|c|c|c|c|c|}
\hline \multirow{4}{*}{ Soil Series } & \multirow{4}{*}{$\begin{array}{c}\begin{array}{c}\text { Total } \\
\text { Sludge } \\
\text { Treatment }\end{array} \\
\text { MT/ha }\end{array}$} & \multirow{3}{*}{\multicolumn{2}{|c|}{$\begin{array}{c}\mathrm{pH} 10 \\
0.1 \mathrm{~N} \\
\mathrm{Na}_{4} \mathrm{P}_{2} \mathrm{G}_{7}{ }^{k *}\end{array}$}} & \multirow{3}{*}{\multicolumn{2}{|c|}{$\begin{array}{l}\mathrm{pH} 9.5 \\
5.25 \% \\
\text { NaOCl** }\end{array}$}} & \multirow{2}{*}{\multicolumn{4}{|c|}{$\begin{array}{l}\mathrm{pH} 2,0.1 \mathrm{M} \mathrm{NH}_{2} \mathrm{OH} \cdot \mathrm{HCl}^{*} \\
\text { Soil/Solution Ratio }\end{array}$}} & \multicolumn{2}{|c|}{$\begin{array}{l}\mathrm{pH} 3,10 \% \\
\mathrm{H}_{2} \mathrm{O}_{2}^{*}\end{array}$} & \multicolumn{2}{|c|}{$\begin{array}{c}\mathrm{pH} \mathrm{2,} 10 \% \\
\mathrm{H}_{2} \mathrm{O}_{2}\end{array}$} & \multirow[b]{3}{*}{ Total } \\
\hline & & & & & & & & & & \multicolumn{4}{|c|}{ Soil/Solution Ratio } & \\
\hline & & & & & & \multicolumn{2}{|c|}{$1: 5$} & \multicolumn{2}{|c|}{$1: 50$} & \multicolumn{2}{|c|}{$1: 5$} & \multicolumn{2}{|c|}{$1: 50$} & \\
\hline & & $\mu \mathrm{g} / \mathrm{g}$ & $\begin{array}{l}\% \text { of } \\
\text { Total }\end{array}$ & $\mu \mathrm{g} / \mathrm{g}$ & $\begin{array}{l}\% \text { of } \\
\text { Total }\end{array}$ & $\mu \mathrm{g} / \mathrm{g}$ & $\begin{array}{l}\text { \% of } \\
\text { Total }\end{array}$ & $\mu g / g$ & $\begin{array}{l}\% \text { of } \\
\text { Total }\end{array}$ & $\mu g_{i}^{\prime} g$ & $\begin{array}{l}\% \text { of } \\
\text { Total }\end{array}$ & $\mu \mathrm{g} / \mathrm{g}$ & $\begin{array}{l}\% \text { of } \\
\text { Total }\end{array}$ & $\mu \mathrm{g} / \mathrm{g}$ \\
\hline \multirow[t]{4}{*}{ Hagerstown } & 0 & - & -- & 43 & 3.7 & 550 & 47 & 747 & 64 & 185 & 16 & 915 & 78 & 1170 \\
\hline & 11.2 & 10.3 & 0.6 & 55 & 3.5 & 750 & 47 & 1150 & 72 & 242 & 15 & 1370 & 86 & 1590 \\
\hline & 22.4 & 10.7 & 0.8 & 38 & 2.7 & 650 & 47 & 850 & 61 & $3 \dot{4} 7$ & 25 & 1020 & 73 & 1390 \\
\hline & 44.8 & 9.6 & 0.6 & 37 & 2.5 & 775 & 53 & 1018 & 69 & 290 & 20 & 1282 & 87 & 1475 \\
\hline Murrill & 89.6 & 7.4 & -- & 30 & -- & 675 & -- & 940 & -- & 237 & -- & 11.90 & -- & -- \\
\hline Chrome & -- & - & -- & - & -- & 80 & -- & -- & -- & 52. & $5--$ & -- & -- & -- \\
\hline
\end{tabular}

*1 extraction

$* * 3$ extractions 
Table 19. Total and NaOCl extractable $\mathrm{Cr}$ in moist Hagerstown silt loam amended with sludge.*

\begin{tabular}{ccc}
\hline & \multicolumn{2}{c}{ Cr added as determined by: } \\
\cline { 2 - 3 } Total Sludge Treatment & Total Analysist* & NaOCl Extraction \\
\hline MT/ha & 3 & 5.0 \\
11.2 & 12 & 10.1 \\
22.4 & 18 & 16.2 \\
\hline 4.8 & & \\
\hline
\end{tabular}

* Samples collected from the first set of plots, only

$* * \mathrm{HF}-\mathrm{HNO}_{3}-\mathrm{H}_{2} \mathrm{SO}_{4}-\mathrm{HClO}_{4}$ digestion

Table 20. Total and NaOCl extractable $\mathrm{Cr}$ in air-dried Hagerstown silt loam amended with sludge.*

\begin{tabular}{cccc}
\hline \multirow{2}{*}{$\begin{array}{c}\text { Total Sludge } \\
\text { Treatment }\end{array}$} & Cr added as determined by: \\
\cline { 2 - 4 } MT/ha & Calculion*** & Total Analysis** & NaOCl Extraction \\
11.2 & 6.5 & 6 & 5.5 \\
22.4 & 13 & 11 & 11.2 \\
44.8 & 26 & 23 & 23.9 \\
\hline
\end{tabular}

* Samples collected from all four sets of plots

$* * \mathrm{HNO}_{3}-\mathrm{H}_{2} \mathrm{O}_{2}-\mathrm{HCl}$ digestion

$\star \star \star$ Calculated from $\mathrm{Cr}$ content of sludge and amount of sludge added to soil 
composite samples from all the plots were analyzed for total and NaOCl extractable $\mathrm{Cr}$ and these data are 1isted in Table 20. By comparing the amount of $\mathrm{Cr}$ added as determined by calculation to the amount of $\mathrm{Cr}$ added as determined by total analysis, it can be seen that nearly all the added $C r$ is still in the top $20 \mathrm{~cm}$ of the soil profile four years after sludge addition ceased. In addition the $\mathrm{NaOCl}$ extraction fairly well accounted for this added $\mathrm{Cr}$. Chromium not extracted by the NaOCl was probably occluded in iron oxides.

From the soil fractionation data we can conclude that $\mathrm{Cr}$ from organic sources is not oxidized in soils and remains associated with the soil organic matter where it is very stable to oxidation." This is supported by the facts that no $\mathrm{Cr}$ (VI) was found in the suil samples from the field plots amended with sludge contaminated with $\mathrm{Cr}$, nearly all the added $\mathrm{Cr}$ remained in the top $20 \mathrm{~cm}$ of the soil profile as determined by the total analysis data, and $\mathrm{NaOCl}$ which oxidizes soil organic matter was able to extract most of the added $\mathrm{Cr}$. It is also possible that some of the $\mathrm{Cr}$ became associated with the soil iron oxides, hut the assnriation was such as to keep the $\mathrm{Cr}$ in a reduced state. Perhaps organo-Cr complexes are sorbed to iron oxides. This possibility needs further study.

Fate of $\mathrm{Cr}$ from Sludge and Leather Dust Applied to Soil in Laboratory Incubation Experiments

The results of the analysis of the samples from the field plots are also supported by the results of laboratory incubation studies with leather dust and sludge. Leather dust is an excellent source of $\mathrm{Cr}$ in that it contains $2.6 \% \mathrm{Cr}$. Potassium phosphate extractions were run on samples from soil incubation studies using leather dust and sludge and 
the results are presented in Table 21 . The results, not surprisingly, are all negative. In the experiment using $50 \mathrm{~g}$ of leather dust a water content of $50 \%$ was established in the incubated soils. Due to the high affinity of organic matter for water and the large amount of leather dust used in the experiment, this high water content was needed to achieve good mixing between the soil and leather dust. At this high water content and with that much organic matter, anaerobic conditions were virtually assured. At low Eh levels oxidation of $\mathrm{Cr}$ is not possible, thus the results are not surprising. In the experiment using 10 $g$ of sludge or leather dust, no additional water was added to the soil samples, and thus more oxidizing conditions were maintained. However, no oxidation of $\mathrm{Cr}$ was observed in this experiment either.

Although not susceptible to oxidation by $\mathrm{MnO}_{2}$, the $\mathrm{Cr}$ in the sludge and leather dust could be oxidized and extracted using $\mathrm{NaOCl}$ as the results in Table 22 show. Three extractions with NaOCl were insufficient to remove all of the added $\mathrm{Cr}$. Five extractions were necessary to remove all of the added $\mathrm{Cr}$. The greater than $100 \%$ recoveries are probably due to non-representative sampling as well as some extraction of natural $\mathrm{Cr}$. The amount of $\mathrm{Cr}$ extracted appears more related to the amount of organic matter added to the soil than the amount of $\mathrm{Cr}$ added. When $10 \mathrm{~g}$ of leather dust or sludge were added, the same fraction of $\mathrm{Cr}$ (83\%) was extracted after three $\mathrm{NaOCl}$ extractions even though much more Cr was added with the leather dust than with the sludge. When $50 \mathrm{~g}$ of leather dust were added the fraction of added $\mathrm{Cr}$ extracted after three extractions decreased to $63 \%$. Thus, additional extractions are necessary to remove all the added $\mathrm{Cr}$ at high organic matter levels. It was observed that a pink color probably due to $M(V I I)$ was found in the NaOC1 solution 
Table 21. Potassium phosphate extractable $\mathrm{Cr}$ (VI) in moist Hagerstown silt loam samples treated with sludge and leather dust in laboratory incubation studies.

\begin{tabular}{cccc}
\hline $\begin{array}{c}\text { Original Sludge } \\
\text { Amendment } \\
\text { in the Field }\end{array}$ & $\begin{array}{c}\text { Amendment in } \\
\text { Laboratory }\end{array}$ & Time & $\begin{array}{c}0.01 \mathrm{M} \mathrm{KH}_{2} \mathrm{PO}_{4} \\
\text { Extractable } \mathrm{Cr}(\mathrm{VI})\end{array}$ \\
\hline $\begin{array}{l}\text { MT/ha } \\
22.4\end{array}$ & $10 \mathrm{~g}$ of sludge & 3 & months \\
& $10 \mathrm{~g}$ of leather dust & 3 & none detected \\
& $50 \mathrm{~g}$ of leather dust & 0.5 & none detected \\
44.8 & & 1.5 & none detected \\
& & 7 & ivile detected
\end{tabular}


Table 22. Sodium hypochlorite extractable $\mathrm{Cr}$ in moist Hagerstown silt loam samples treated with sludge and leacher dust in laboratory incubation studies.

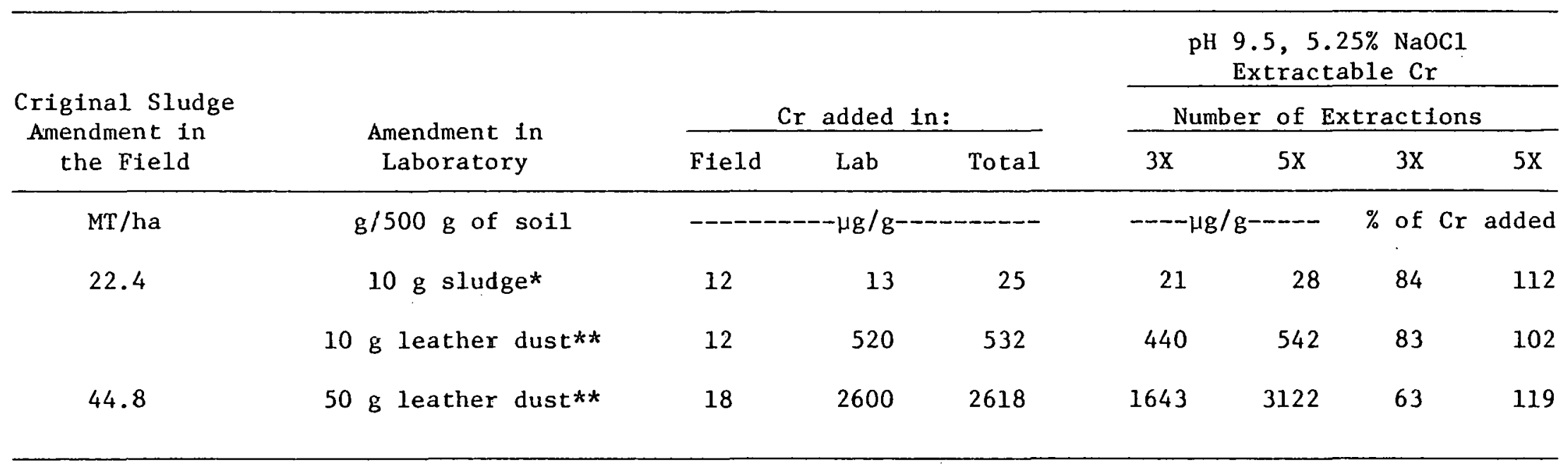

$* 660 \mu \mathrm{g} / \mathrm{g} \mathrm{Cr}$

$* x 2.6 \% \mathrm{Cr}$ 
after all the organic matter was apparently destroyed. This observation would be useful for routine analyses to decide when enough extractions had been performed.

Effect of Drying, Storage Time, and Organic Matter Removal on the Ability of Soil to Oxidize $\mathrm{Cr}$

Although $\operatorname{Cr}($ III) in organic matter and chromite is not oxidized in soil, $\mathrm{Cr}$ (III) from inorganic sources such as $\mathrm{CrCl}_{3}$ solutions is oxidized in soils as Bartlett and James (1979) first demonstrated. A modified version of their $\mathrm{Cr}$ oxidation test was used to study the effects of. drying, storage time, and organic matter removal on the Cr oxidizing ability of Hagerstown and Murrill soils and to compare the $\mathrm{Cr}$ oxidizing ability of the Chrome soil with the Hagerstown and Murrill soils. The results are summarized in Table 23. The effects of drying and $\mathrm{Cr}$ oxidation on Mn reduction are also summarized in Table 23. The first thing to note is the strong effect drying had on the $\mathrm{Cr}$ oxidizing ability of the soils. Air-drying the soils led to a substantial loss of $\mathrm{Cr}$ oxidirilly allllly. Oven-drylng vireualiy deströyed Ehé l'r oxidizing ability of the soils. There was also a loss of $\mathrm{Cr}$ oxidizing ability with storage over time. There was no loss of $\mathrm{Cr}$ oxidizing ability of the moist soils for the first three months of storage. Beyond three months the ability of the soils to oxidize $\operatorname{Cr}$ declined. After 1 year the moist Hagerstown soils were able to oxidize about one-third as much $\mathrm{Cr}$ as they did at three months. The Cr oxidizing ability of the Murrill soil declined more slowly even though it contained more organic matter. The air-dried soils lost most of their $\mathrm{Cr}$ oxidizing ability during the initial stage of drying, but small losses also occurred during storage 
Table 23. Chromium oxidizing ability of Hagerstown, Murrill, and Chrome soils as affected by drying, storage time, and organic matter removal.

\begin{tabular}{|c|c|c|c|c|c|c|c|c|c|c|}
\hline \multirow{2}{*}{$\begin{array}{l}\text { Soil } \\
\text { Series }\end{array}$} & \multirow{2}{*}{$\begin{array}{c}\text { Total } \\
\text { Sludge } \\
\text { Treatment }\end{array}$} & \multirow[b]{2}{*}{ Drying } & \multirow{2}{*}{$\begin{array}{l}\text { Storage } \\
\text { Time }\end{array}$} & \multicolumn{2}{|c|}{$\begin{array}{c}0.01 \mathrm{M} \mathrm{KH}_{2} \mathrm{PO}_{4} \\
\text { Extractable } \\
\end{array}$} & \multirow{2}{*}{$\begin{array}{c}0.5 \mathrm{M} \mathrm{CaCl}_{2} \\
\text { Extractable } \\
\text { Mn(II) After } \\
\mathrm{Cr} \text { Oxidation } \\
\text { Test }\end{array}$} & \multirow{2}{*}{$\begin{array}{l}\text { Total } \\
\operatorname{Mn}(I I)\end{array}$} & \multirow{2}{*}{$\begin{array}{c}\text { Initial } \\
0.5 \mathrm{M} \mathrm{CaCl}_{2} \\
\text { Extractable } \\
\quad \mathrm{Mn}(\mathrm{II})\end{array}$} & \multirow{2}{*}{$\begin{array}{l}\text { Net } \\
\text { Total } \\
\text { Mn(II) } \\
\text { Produced }\end{array}$} & \multirow{2}{*}{$\begin{array}{l}\operatorname{Mn}(\mathrm{II}) / \\
\mathrm{Cr}(\mathrm{VI})\end{array}$} \\
\hline & & & & $\operatorname{Cr}(V I)$ & $\operatorname{Mn}(\mathrm{II})$ & & & & & \\
\hline & MT/ha & & menths & -- & $\cdots$ & $-\cdots$ & -nmole & - & - & -- \\
\hline \multirow{18}{*}{$\begin{array}{l}\text { Hagers- } \\
\text { town }\end{array}$} & 0 & no & & & & & & & & \\
\hline & & & 3 & 117 & 13.8 & $\begin{array}{l}167 \\
138\end{array}$ & 181 & 34.2 & 147 & 1.3 \\
\hline & & & $\begin{array}{r}4 \\
12\end{array}$ & $\begin{array}{l}86.1 \\
36.9\end{array}$ & $\begin{array}{c}8.0 \\
--\end{array}$ & $\begin{array}{l}138 \\
--\end{array}$ & $\begin{array}{l}146 \\
--\end{array}$ & $\begin{array}{l}34.9 \\
--\end{array}$ & 111 & $\begin{array}{l}1.3 \\
--\end{array}$ \\
\hline & & air-dry & 3 & 27.7 & 94.5 & 400 & 494 & 465 & 29 & 1.0 \\
\hline & & & 4 & 9.2 & 74.9 & 465 & 540 & 451 & 89 & 9.7 \\
\hline & & & 12 & -- & -- & -- & -- & -- & -- & -- \\
\hline & & oven-dry & 3 & 0.0 & 945 & 2836 & 3781 & 3636 & 144 & -- \\
\hline & & & 4 & 0.0 & 873 & 3418 & 4291 & 4291 & 0 & -- \\
\hline & & & 12 & -- & -- & -- & -- & -- & -- & -- \\
\hline & 11.2 & no & 3 & 129 & 10.9 & 175 & 186 & 34.2 & 152 & 1.2 \\
\hline & & & 4 & 111 & 7.3 & 153 & 160 & 33.5 & 126 & 1.1 \\
\hline & & & 12 & 43.1 & -- & -- & -- & -- & -- & -- \\
\hline & & air-dry & 3 & 36.9 & 87.3 & 458 & 545 & 393 & 152 & 4.1 \\
\hline & & & 4 & 15.4 & 75.6 & 531 & 607 & 487 & 120 & 8.0 \\
\hline & & & 12 & 2.3 & -- & -- & -- & -- & -- & -- \\
\hline & - & oven-dry & 3 & 1.5 & 800 & 2982 & 3782 & 4000 & -218 & -- \\
\hline & & & 4 & 1.5 & 727 & 3782 & 4509 & 4873 & -364 & -- \\
\hline & & & 12 & - & - & -- & -- & -- & -- & -- \\
\hline
\end{tabular}


Table 23 (Continued).

\begin{tabular}{|c|c|c|c|c|c|c|c|c|c|c|}
\hline \multirow{2}{*}{$\begin{array}{l}\text { Soil } \\
\text { Series }\end{array}$} & \multirow{2}{*}{$\begin{array}{c}\text { Total } \\
\text { Sludge } \\
\text { Treatment }\end{array}$} & \multirow[b]{2}{*}{ Drying } & \multirow{2}{*}{$\begin{array}{l}\text { Storage } \\
\text { Time }\end{array}$} & \multicolumn{2}{|c|}{$\begin{array}{c}0.01 \mathrm{M} \mathrm{KH}_{2} \mathrm{PO}_{4} \\
\text { Extracta\$口 } \\
\end{array}$} & \multirow{2}{*}{$\begin{array}{c}0.5 \mathrm{M} \mathrm{CaCl}_{2} \\
\text { Extractable } \\
\text { Mn(II) After } \\
\mathrm{Cr} \text { Oxidation } \\
\text { Test }\end{array}$} & \multirow{2}{*}{$\begin{array}{l}\text { Total } \\
\operatorname{Mn}(I I)\end{array}$} & \multirow{2}{*}{$\begin{array}{c}\text { Initial } \\
0.5 \mathrm{M} \mathrm{CaCl}_{2} \\
\text { Ertractable } \\
\operatorname{In}(\mathrm{II})\end{array}$} & \multirow{2}{*}{$\begin{array}{l}\text { Net } \\
\text { Total } \\
\text { Mn(II) } \\
\text { Produced }\end{array}$} & \multirow{2}{*}{$\begin{array}{l}\operatorname{Mn}(\mathrm{II}) / \\
\operatorname{Cr}(\mathrm{VI})\end{array}$} \\
\hline & & & & $\mathrm{Cr}(\mathrm{VI})$ & $\operatorname{Mn}(I I)$ & & & & & \\
\hline & MT/ha & & months & ---- & - - & ---- & $-\mathrm{rmole} / \mathrm{g}$ & g- - - n- & ----- & $\cdots$ \\
\hline \multirow[t]{6}{*}{$\begin{array}{l}\text { Hagers- } \\
\text { town }\end{array}$} & 22.4 & no & $\begin{array}{r}3 \\
4 \\
12\end{array}$ & $\begin{array}{l}86.2 \\
67.7 \\
21.5\end{array}$ & $\begin{array}{l}15.3 \\
10.2 \\
--\end{array}$ & $\begin{array}{l}175 \\
116 \\
--\end{array}$ & $\begin{array}{l}190 \\
126 \\
--\end{array}$ & $\begin{array}{l}49.5 \\
62.5 \\
--\end{array}$ & $\begin{array}{r}1.41 \\
63 \\
--\end{array}$ & $\begin{array}{l}1.6 \\
0.9 \\
--\end{array}$ \\
\hline & & air-dry & $\begin{array}{r}3 \\
4 \\
12\end{array}$ & $\begin{array}{r}310.8 \\
13.8 \\
1.5\end{array}$ & $\begin{array}{l}94.5 \\
94.5 \\
--\end{array}$ & $\begin{array}{l}473 \\
553 \\
--\end{array}$ & $\begin{array}{l}567 \\
647 \\
--\end{array}$ & $\begin{array}{r}436 \\
516 \\
--\end{array}$ & $\begin{array}{r}131 \\
131 \\
--\end{array}$ & $\begin{array}{l}4.2 \\
9.4 \\
--\end{array}$ \\
\hline & & oven-dry & $\begin{array}{r}3 \\
4 \\
12\end{array}$ & $\begin{array}{l}1.5 \\
0.0 \\
--\end{array}$ & $\begin{array}{r}1164 \\
872 \\
--\end{array}$ & $\begin{array}{c}3200 \\
4145 \\
--\end{array}$ & $\begin{array}{c}4364 \\
5017 \\
--\end{array}$ & $\begin{array}{r}4218 \\
6400 \\
--\end{array}$ & $\begin{array}{r}146 \\
-1383 \\
--\end{array}$ & $\begin{array}{l}-- \\
--\end{array}$ \\
\hline & 44.8 & no & $\begin{array}{r}3 \\
4 \\
12\end{array}$ & $\begin{array}{r}129 \\
92.3 \\
40.0\end{array}$ & $\begin{array}{l}7.3 \\
3.6 \\
--\end{array}$ & $\begin{array}{r}109 \\
80 \\
--\end{array}$ & $\begin{array}{r}116 \\
84 \\
--\end{array}$ & $\begin{array}{l}10.2 \\
13.1 \\
-\div\end{array}$ & $\begin{array}{r}106 \\
71 \\
--\end{array}$ & $\begin{array}{l}0.8 \\
0.8 \\
--\end{array}$ \\
\hline & & afr-dry & $\begin{array}{r}3 \\
4 \\
12\end{array}$ & $\begin{array}{r}49.2 \\
21.5 \\
2.3\end{array}$ & $\begin{array}{l}27.6 \\
28.4 \\
--\end{array}$ & $\begin{array}{l}240 \\
291 \\
--\end{array}$ & $\begin{array}{l}268 \\
319 \\
--\end{array}$ & $\begin{array}{r}167 \\
218 \\
--\end{array}$ & $\begin{array}{r}101 \\
101 \\
--\end{array}$ & $\begin{array}{l}2.1 \\
4.8 \\
--\end{array}$ \\
\hline & & oven-dry & $\begin{array}{r}3 \\
4 \\
12\end{array}$ & $\begin{array}{l}0.0 \\
0.0 \\
--\end{array}$ & $\begin{array}{l}\square 45 \\
; 27 \\
--\end{array}$ & $\begin{array}{c}2982 \\
3273 \\
-\end{array}$ & $\begin{array}{c}3927 \\
4000 \\
-\end{array}$ & $\begin{array}{r}3782 \\
4655 \\
--\end{array}$ & $\begin{array}{r}145 \\
-655 \\
--\end{array}$ & $\begin{array}{l}-- \\
-- \\
--\end{array}$ \\
\hline
\end{tabular}


Table 23 (Continued).

\begin{tabular}{|c|c|c|c|c|c|c|c|c|c|c|}
\hline \multirow{2}{*}{$\begin{array}{l}\text { Soil } \\
\text { Series }\end{array}$} & \multirow{2}{*}{$\begin{array}{c}\text { Total } \\
\text { Sludge } \\
\text { Treatment }\end{array}$} & \multirow[b]{2}{*}{ Drying } & \multirow{2}{*}{$\begin{array}{l}\text { Storage } \\
\text { Time }\end{array}$} & \multicolumn{2}{|c|}{$\begin{array}{c}0.01 \mathrm{M} \mathrm{KH}_{2} \mathrm{PO}_{4} \\
\text { Extractable }\end{array}$} & \multirow{2}{*}{$\begin{array}{l}0.5 \mathrm{M} \mathrm{CaCl}_{2} \\
\text { Extractable } \\
\text { Mn(II) After } \\
\text { Cr Oxidation } \\
\text { Test }\end{array}$} & \multirow{2}{*}{$\begin{array}{l}\text { Total } \\
\text { Mn(II) }\end{array}$} & \multirow{2}{*}{$\begin{array}{c}\text { Initial } \\
0.5 \mathrm{M} \mathrm{CaCl}_{2} \\
\text { Extractable } \\
\text { Mn(II) }\end{array}$} & \multirow{2}{*}{$\begin{array}{l}\text { Net } \\
\text { Total } \\
\text { Mn(II) } \\
\text { Produced }\end{array}$} & \multirow{2}{*}{$\begin{array}{l}\operatorname{Mn}(\mathrm{II}) / \\
\mathrm{Cr}(\mathrm{VI})\end{array}$} \\
\hline & & & & $\operatorname{Cr}(V I)$ & $\operatorname{Mn}(\mathrm{II})$ & & & & & \\
\hline & $\mathrm{MT} / \mathrm{ha}$ & & months & $---\cdots$ & $-\cdots-\cdots$ & $--\cdots-\cdots-\cdots$ & - nmole $/ \varepsilon$ & g- - - - - - & --- & $\cdots-$ \\
\hline \multirow[t]{9}{*}{ Murrill } & 89.6 & no & 3 & 92.3 & 2.2 & 35.6 & 38 & 2.9 & 35 & 0.4 \\
\hline & & & 4 & 80.0 & 1.5 & 27.6 & 29 & 5.8 & 23 & 0.3 \\
\hline & & & 12 & 64.6 & -- & -- & -- & -- & -- & -- \\
\hline & & air-dry & 3 & 50.8 & 5.1 & 109 & 114 & 30.5 & 84 & 1.6 \\
\hline & & & 4 & 27.7 & 5.1 & 138 & 143 & 72.7 & 70 & 2.5 \\
\hline & & & 12 & 3.8 & -- & -- & -- & -- & -- & -- \\
\hline & & oven-dry & 3 & 1.5 & 276 & 1818 & 2094 & 1964 & 130 & -- \\
\hline & & & 4 & 4.6 & 247 & 1818 & 2065 & 2109 & -44 & -- \\
\hline & & & 12 & - & -- & -- & -- & -- & -- & -- \\
\hline $\begin{array}{l}\text { Hagers- } \\
\text { town* }\end{array}$ & 44.8 & no & 3 & 127 & -- & -- & -- & -- & -- & -- \\
\hline Chrome & -- & no & 4 & 75 & -- & -- & -- & -- & -- & -- \\
\hline
\end{tabular}

*Jrganic matter removed using $\mathrm{pH} 9.5,5.25 \% \mathrm{NaOCl}$ 
over time. Air-dried soil samples are normally considered stable, but these data indicate that even air-dried soils change over time.

The reason for the loss of $\mathrm{Cr}$ oxidizing ability can be found by examining the Mn data. It is clear that air-drying the soils led to an increase in extractable Mn(II) ions. Oven-drying led to an even greater increase. Storage also generally resulted in an increase. The explanation is that as the soil was dried changes in the organic matter occurred that led to a decrease in the Eh of. the soil. As the Eh fell the manganese oxides were reduced yielding Mn(II) (Bartlett and James, 1980). If cnough of the manganese uxides are reduced, none are left to nxidize any added $\mathrm{Cr}$ which is why this reaction was unknown in soils until the discovery of Bartlett and James (1979). It is the almost universal practice of virtually every soils lab to dry soil samples before studying them. Such a practice must be discontinued if an accurate determination of the redox properties of soils is to be made.

It was also possible to evaluate the amount of Mn that was reduced during $\mathrm{Cr}$ oxidation. The $\mathrm{Mn}$ (II) content of cach $0.01 \mathrm{M} \mathrm{IOI}_{2} \mathrm{FO}_{4}$ extiat= tant was added to the $\mathrm{Mn}(\mathrm{II})$ extractable with $0.5 \mathrm{M} \mathrm{CaCl}_{2}$ after each $\mathrm{Cr}$ oxidation test to give the total extractable Mn(II) in each soil. From the total $\mathrm{Mn}$ (II) was subtracted the initial $0.5 \mathrm{M} \mathrm{CaCI}, 2$ extractable $M n(I I)$ In each soil before the $C r$ oxidation test was run. The calculated result gave the net $M n$ (II) produced as a result of $\mathrm{Cr}$ oxidation. Assuming that all of the soil manganese oxide is $\delta-\mathrm{MnO}_{2}$, then the stoichiometry of the reaction:

$$
\mathrm{Cr}^{3+}+1.50-\mathrm{MnO}_{2}+\mathrm{H}_{2} \mathrm{O}=\mathrm{HCrO}_{4}^{-}+1.5 \mathrm{Mn}^{2+}+\mathrm{H}^{+}
$$

predicts that 1.5 moles of $M($ II) will be produced for every mole of $\mathrm{HCrO}_{4}^{-}$yielded. The ratio of $\mathrm{Mn}$ (II) to $\mathrm{Cr}(\mathrm{VI})$ for each soil is shown in 
Table 23. Since no $C r$ was oxidized by the oven-dry soils, the total $\mathrm{Mn}$ (II) and net total $\mathrm{Mn}$ (II) in oven-dry soils should theoretically be the same. Any discrepancies were due to sample variability. For the case of the air-dry soils the variability of the net Mn(II) produced was too great to deduce anything useful from the $\mathrm{Mn}(\mathrm{II}) / \mathrm{Cr}$ (VI) ratio. However, for three of the moist soils the $\operatorname{Mn}(\mathrm{II}) / \mathrm{Cr}$ (VI) ratio seems reasonably close to the theoretically predicted 1.5 value. These soils contained less organic matter and had lower $\mathrm{pH}$ values than the two soils where the $\operatorname{Mn}(I I) / C r(V I)$ ratios were less than one. The higher $\mathrm{pH}$ levels and/or organic matter contents of those two soils may have caused less $\mathrm{Mn}$ (II) to be extracted with the $\mathrm{CaCl}_{2}$.

Removal of organic matter from a sample of Hagerstown soil amended with $44.8 \mathrm{MT} /$ ha sludge did not result in an increase in the amount of Cr oxidized as compared to an untreated soil. Evidence contradicting this result will be presented later.

Despite the low level of $\mathrm{NH}_{2} \mathrm{OH} \cdot \mathrm{HCl}$ and $\mathrm{H}_{2} \mathrm{O}_{2}$ reducible $\mathrm{Mn}$ in the Chrome soil, there was apparently enough manganese oxide there to yield only slightly less oxidized $\mathrm{Cr}$ than the Hagerstown and Murrill soils yielded. However, the $\mathrm{Cr}$ added to the soils was a highly soluble form easily oxidized by $\mathrm{MnO}_{2}$ coatings over soil particles, so this finding may not be significant.

The effect of water removal by various treatments on the $\mathrm{Cr}$ oxidizing ability of Murrill silt loam was examined and the results are presented in Table 24. Each sample was amended with $\operatorname{Cr}$ (III), treated to remove water, and then analyzed for $0.01 \mathrm{M} \mathrm{KH}_{2} \mathrm{PO}_{4}$ extractable $\mathrm{Cr}(\mathrm{VI})$. It is apparent that oven-drying was able to reverse the oxidation process. However, water removal by washing with an organic solvent resulted in 
Table 24. Effect of water removal by various treatments on the $\mathrm{Cr}$ oxidizing ability of Murrill silt loam.

\begin{tabular}{|c|c|c|c|}
\hline Treatment & $0.01 \mathrm{M} \mathrm{KH}_{2} \mathrm{PO}_{4}$ & Extractable & $\mathrm{Cr}(\mathrm{VI})$ \\
\hline & & $\mu g / g$ & \\
\hline none & & 4.16 & \\
\hline oven drying at $105^{\circ} \mathrm{C}$ & & 0.08 & \\
\hline alcohol wash & & 1.92 & \\
\hline alcohol wash + oven dry & & 0.40 & \\
\hline Acetone wash & & 3.04 & \\
\hline acetone wash + oven dry & & 2.00 & \\
\hline
\end{tabular}


incomplete reversal of the $\dot{C}$ r oxidation reaction. Even with oven-drying following the washing with solvent, the reaction could not be entirely reversed. No completely satisfactory explanation of these observations is available yet, but it may be related to the rate or completeness of water removal. Oven-drying results in slow water removal while solvent washing results in rapid water removal. Chromium reduction may be slow upon drying.

Effect of $\mathrm{Cr}$ Concentration on $\mathrm{Cr}$ Oxidation by Soil

At this point it might be useful to ask what is the relationship between the amount of $\operatorname{Cr}$ (III) added to soil and the amount of $\operatorname{Cr}$ (VI) produced. This question is partially answered by Figures 10 and 11 . In Figure 10, the amount of $\mathrm{Cr}$ oxidized expressed as a percent of the amount of $\operatorname{Cr}$ (III) added is shown as a function of the amount of $\operatorname{Cr}$ (III) added. This experiment covered a wide range of added $\operatorname{Cr}$ (III) amounts and it clearly shows that as the amount of added $\operatorname{Cr}$ (III) increased the fraction of added $\mathrm{Cr}$ that was oxidized decreased. In no case did the amount of $\mathrm{Cr}$ oxidized amount to more than a few percent of the amount of added $\mathrm{Cr}$. According to the Mn fractionation data the soil used in this experiment contained about $1300 \mathrm{\mu g} / \mathrm{g}$ of reducible $\mathrm{Mn}$ (using $\mathrm{pH} \mathrm{2,10 \%}$ $\mathrm{H}_{2} \mathrm{O}_{2}$ at $1: 50$ soil/solution ratio). Assuming this was all $\delta-\mathrm{MnO}_{2}$ and all accessible to the $\mathrm{Cr}$, this much reducible $\mathrm{Mn}$ should have been able to oxidize about $800 \mathrm{\mu g} / \mathrm{g}$ of $\mathrm{Cr}$. This would have been enough to oxidize all of the added $\mathrm{Cr}$ except for the highest rate added $(1000 \mu \mathrm{g} / \mathrm{g})$. The fact that only a small fraction of the added $C_{r}$ was actually oxidized indicates that either very little of the manganese oxides present were actually accessible to the $\mathrm{Cr}$, or that only a small fraction of the $\mathrm{Cr}$ added was available for oxidativin oi buth. The Eraction of added er 


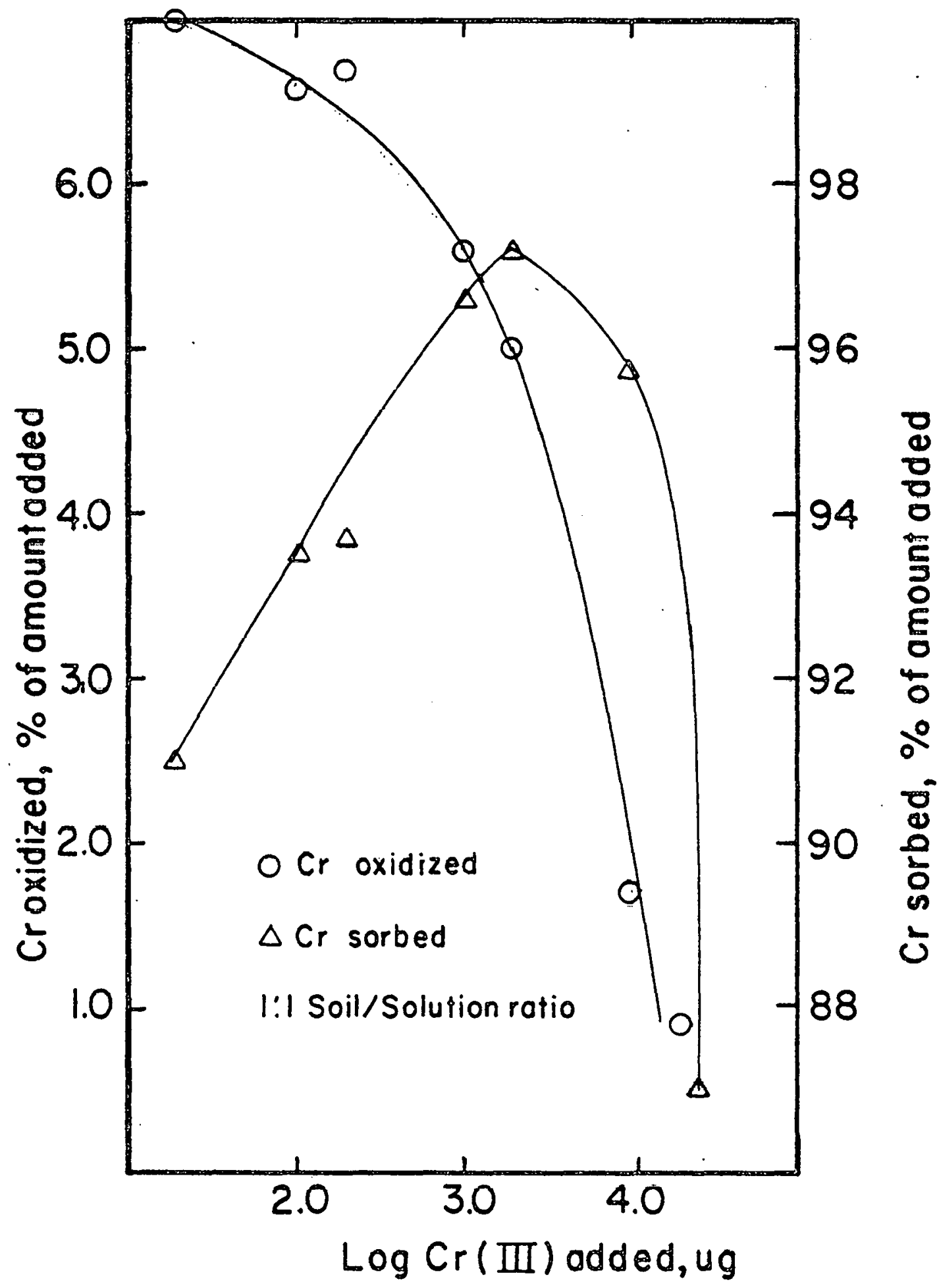

Figure 10. Effect of varying $\operatorname{Cr}$ (III) concentrations on the fraction of added $\mathrm{Cr}$ that is sorbed or oxidized by moist Hagerstown silt loam. 
that was sorbed by the soil is also plotted in Figure 10 as a function of the amount of $\mathrm{Cr}$ added. It is clear that most of the added $\mathrm{Cr}$ was sorbed by the soil reaching a maximum at $100 \mu \mathrm{g} / \mathrm{g}$ of added $\mathrm{Cr}$. If all of the sorbed $C_{r}$ was sorbed by organic matter and iron oxides and was unavailable for oxidation, then the amount remaining in solution would account for the small fraction that was oxidized. Sorption by organic matter and iron oxides is the most 1ikely explanation for immobilization of added $\operatorname{Cr}$ (III), since Schnitzer (1980, Agronomy Abstracts, p. 159) has shown humic acids have a high affinity for $\operatorname{Cr}$ (III) and Grove and Ellis (1980) have shown that when $\operatorname{Cr}$ (III) was added to soil a large fraction of added $C_{r}$ was extracted with the free iron oxides.

In Figure 10 the fractions of added $\mathrm{Cr}$ that were oxidized and sorbed were plotted against the amount of added $\mathrm{Cr}$. In Figure 11 the amounts of soil solution total $\operatorname{Cr}$ and $\operatorname{Cr}(V I)$, extractable $\operatorname{Cr}(V I)$, and total $\operatorname{Cr}(V I)$ produced are plotted against the amount of added $\mathrm{Cr}$. At lower amounts of added $\mathrm{Cr}$ most of the $\mathrm{Cr}$ (VI) produced remained in the soil solution. As the amount of $\mathrm{Cr}$ added increased the fraction of $\mathrm{Cr}(\mathrm{VI})$ that became sorbed to the soil, and hence extractable with $\mathrm{KH}_{2} \mathrm{PO}_{4}$ increased until the $\operatorname{Cr}(V I)$ was approximately equally distributed between soil and solution. At lower amounts of added $\mathrm{Cr}, \mathrm{Cr}$ (VI) accounted for nearly all of the solution $\mathrm{Cr}$, but as the amount of added $\mathrm{Cr}$ increased, the fraction of solution $\mathrm{Cr}$ that was $\mathrm{Cr}(\mathrm{VI})$ decreased. Assuming that only the $\operatorname{Cr}$ (III) remaining in solution was available for oxidation, then there was sufficient $\mathrm{MnO}_{2}$ in the soil to oxidize all of the solution $\operatorname{Cr}($ III). Since it was not all oxidized, all of the reducible Mn must not be available for oxidizing the $\mathrm{Cr}$. The total $\mathrm{Cr}(\mathrm{VI})$ produced seemed to have reached a maximum far below what the soil was theoretically 


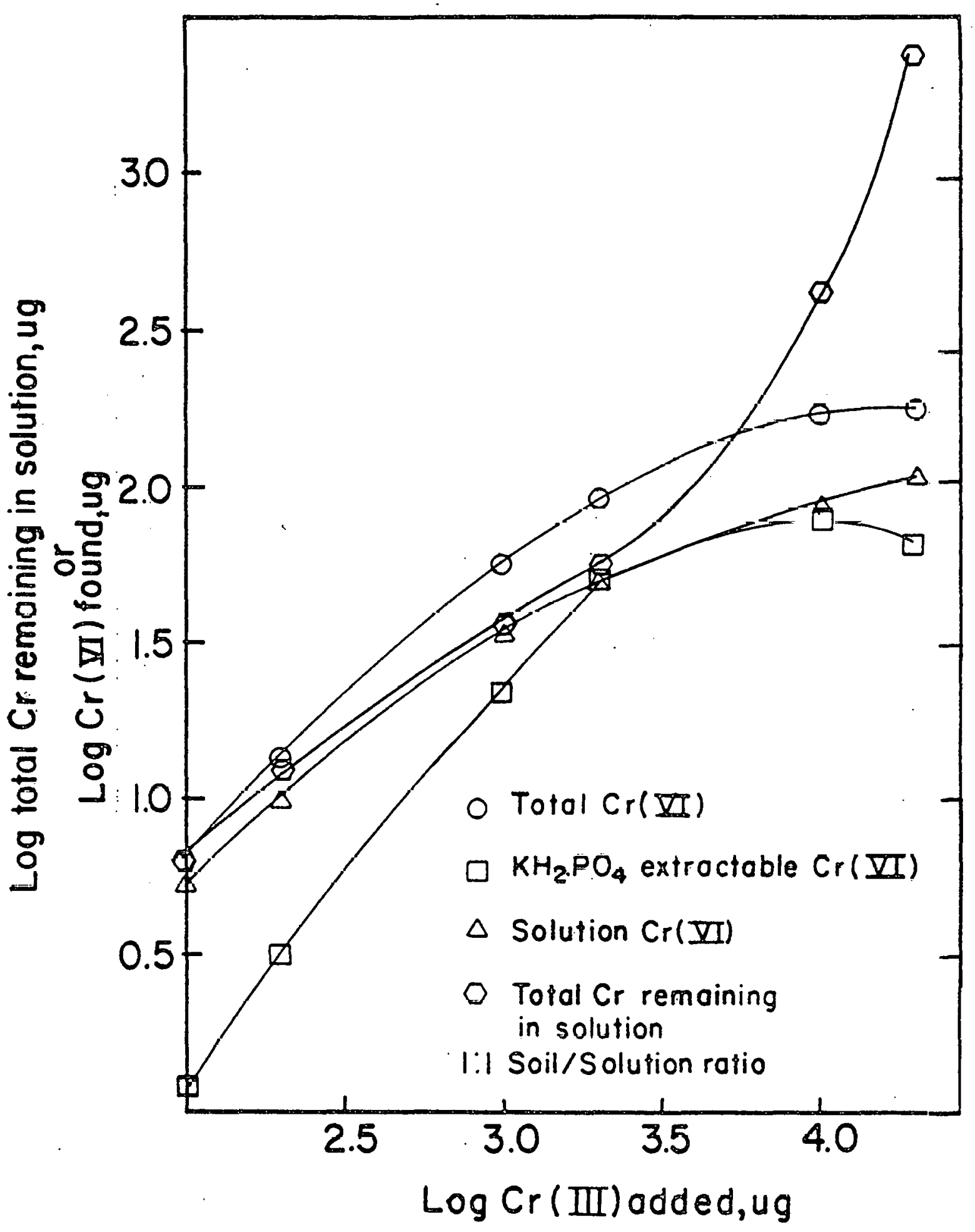

Figure 11. Effect of varying $\operatorname{Cr}$ (III) concentrations on the amount of soil solution total $\mathrm{Cr}$ and $\mathrm{Cr}(\mathrm{VI}), \mathrm{KH}_{2} \mathrm{PO}_{4}$ extractable $\mathrm{Cr}(\mathrm{VI})$, and total $\mathrm{Cr}(\mathrm{VI})$ produced in moist Hagerstowa silt loam. 
capable of producing. Thus, soils probably have a finite capacity to oxidize $\mathrm{Cr}$ that is below the theoretical maximum. The theoretical maximum is given by the amount of reducible $\mathrm{Mn}$ in the soil and the stoichiometry of the reaction between $\mathrm{Cr}$ and $\mathrm{Mn}$.

\section{Cr Oxidizing Capacity of Soil}

Fịgures 10 and 11 imply a finite capacity of soil to oxidize $\mathrm{Cr}$. This is demonstrated in Figure 12. where a sample of Hagerstown soil amended with $44.8 \mathrm{MT} / \mathrm{ha}$ sludge was repeatedly equilibrated with a 1000 $\mu g / m 1 \operatorname{Cr}(I I I)$ solution. The fraction of added $\mathrm{Cr}$ sorbed, the $\mathrm{Cr}(\mathrm{VI})$ in the $1000 \mu \mathrm{g} / \mathrm{ml} \operatorname{Cr}($ III) solution after each equilibration, and the concentration of $\mathrm{Mn}$ (II) released to solution are all plotted as a function of the number of equilibrations (extractions). With each extraction, the fraction of added $\operatorname{Cr}$ that was sorbed decreased approximately by a factor of two. The $\mathrm{Cr}(\mathrm{VI})$ in solution decreased but not by a uniform factor. The Mn(II) concentration of the equilibrating solution increased almost linearly for the first four extractions and then declined as the capacity of the soil to oxidize $C r$ was almost exhausted. Thus, the soil's capacity to oxidize $\mathrm{Cr}$ was nearly exhausted after a total of 234 Himole/l of solution $\operatorname{Cr}$ (VI) were produced.

Extractability of Soil $\mathrm{Cr}$ (VI) with $\mathrm{KH}_{2} \mathrm{PO}_{4}$

Many of the experiments have relied on data obtained using $\mathrm{KH}_{2} \mathrm{PO}_{4}$ extractions of the soil. However, little is known about the details of a $\mathrm{KH}_{2} \mathrm{PO}_{4}$ extractable $\mathrm{Cr}(\mathrm{V} 1)$ test for soils. Therefore, a series of experiments were run to study the nature of $\operatorname{Cr}(V I)$ extraction from soils using $\mathrm{KH}_{2} \mathrm{PO}_{4}$. In the first experiment $\mathrm{Cr}(\mathrm{VI})$ was extracted from a moist Hagerstown silt loam previously trealed with $\operatorname{Cr}($ III) using solutions of 


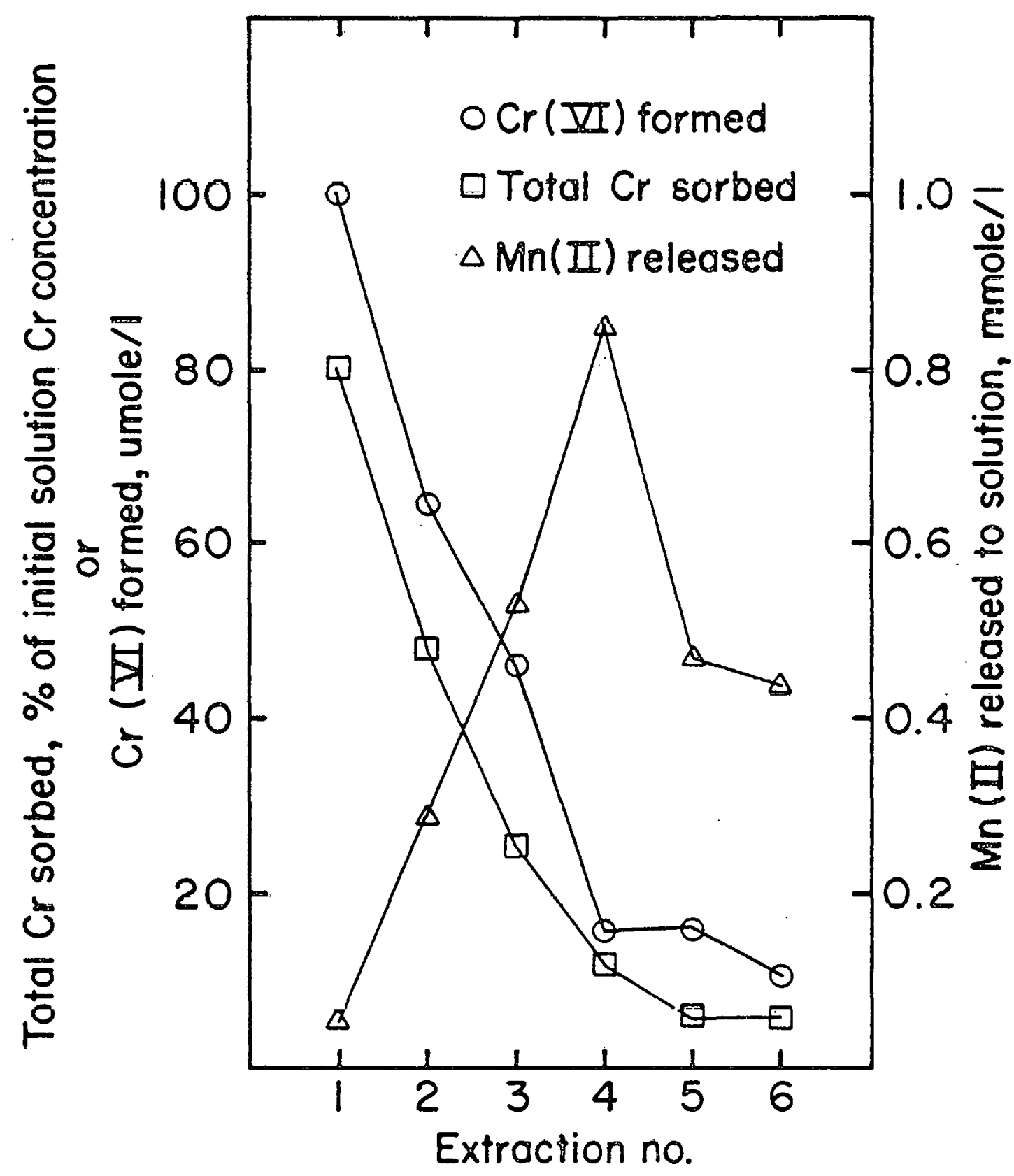

Figure 12. Exhaustion of $\mathrm{Cr}$ oxidizing capacity of moist Hagerstown silt loam. 
varying $\mathrm{KH}_{2} \mathrm{PO}_{4}$ concentrations and the results are given in Table 25 . There was no significant difference in the amount of $\operatorname{Cr}$ (VI) extracted by the three solutions. A solution containing $0.01 \mathrm{M} \mathrm{KH}_{2} \mathrm{PO}_{4}$ is sufficient to extract $\mathrm{Cr}(\mathrm{VI})$. If it is assumed that $\mathrm{H}_{2} \mathrm{PO}_{4}^{-}$ions replace $\mathrm{HCrO}_{4}^{-}$ions on the soil and the exchange reaction is governed by a mass action formulation, then if the $0.01 \mathrm{M} \mathrm{KH}_{2} \mathrm{PO}_{4}$ did not extract all the $\mathrm{Cr}(\mathrm{VI})$, solutions with higher concentrations of $\mathrm{KH}_{2} \mathrm{PO}_{4}$ would have. Since this did not happen, the $0.01 \mathrm{M} \mathrm{KH}_{2} \mathrm{PO}_{4}$ solution must be adequate.

Apparently contradictory evidence was obtained by running successive $\mathrm{KH}_{2} \mathrm{PO}_{4}$ extractions for $\mathrm{Cr}(\mathrm{VI})$ on moist Hagerstown silt loam treated with three levels of $\operatorname{Cr}$ (III) as shown in Figure 13. This diagram apparently shows that one extraction with $0.01 \mathrm{M} \mathrm{KH}_{2} \mathrm{PO}_{4}$ was not sufficient to remove all of the $\operatorname{Cr}(V I)$. However, it is possible that the first extraction did remove nearly all of the $\operatorname{Cr}(\mathrm{VI})$ and that the $\operatorname{Cr}(\mathrm{VI})$ removed by subsequent extractions was mostly produced through oxidation during those extractions. If the $\mathrm{KH}_{2} \mathrm{PO}_{4}$ was able to desorb some of the added Cr(III) that was originally unavailable for oxidation, thereby making it available for oxidation, this would account for the discrepancy between the results in Table 25 and Figure 13.

To further characterize the extraction of $\mathrm{Cr}(\mathrm{VI})$ using $\mathrm{KH}_{2} \mathrm{PO}_{4}$, the effect of the soil to extracting solution ratio on the results was studied. In the first experiment the soil/solution ratio was varied by holding the amount of soil constant while varying the $\mathrm{KH}_{2} \mathrm{PO}_{4}$ solution volume and the resules are presented in Table 26 . The results show that a $1: 1$ soil/solution ratio did not give as much extractable $\operatorname{Cr}$ (VI) as did the other three ratios. The 1:1 ratio was used in the experiment where the concentration of $\mathrm{KH}_{2} \mathrm{PO}$, was varied and in the successive extraction 
Table 25. Chromium(VI) extracted from moist Hagerstown silt loam using various concentrations of $\mathrm{KH}_{2} \mathrm{PO}_{4}$ in solution.

\begin{tabular}{|c|c|c|c|}
\hline $\mathrm{KH}_{2} \mathrm{PO}_{4}$ & Concentration & $\operatorname{Cr}(\mathrm{VI})$ & Extracted \\
\hline & & & $\mu g / g$ \\
\hline & $0.1 \mathrm{M}$ & & 8.4 \\
\hline & $0.05 \mathrm{M}$ & & 8.0 \\
\hline & $0.01 \mathrm{M}$ & & 8.1 \\
\hline
\end{tabular}




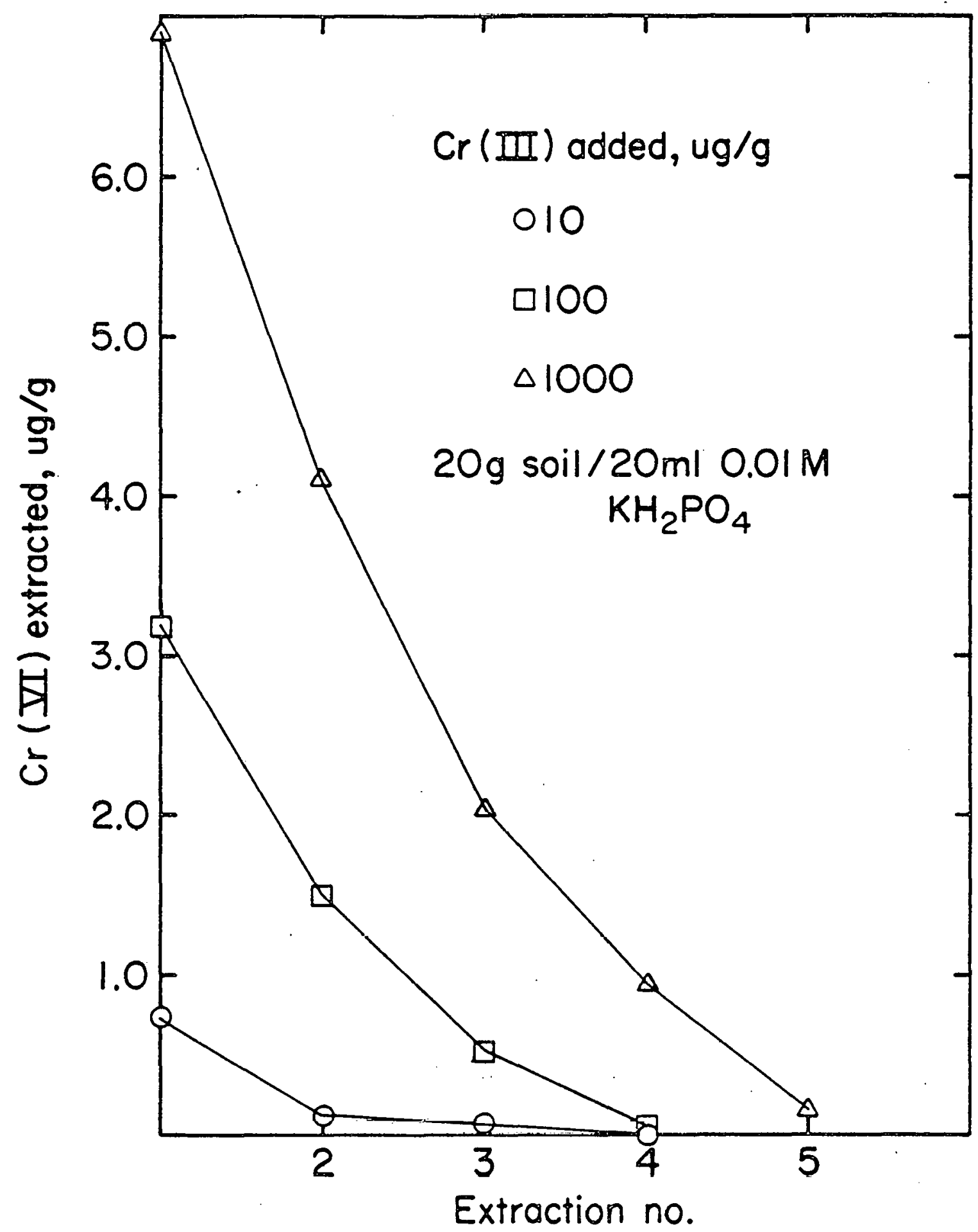

Figure 13. Successive $\mathrm{KH}_{2} \mathrm{PO}_{4}$ extractions of $\mathrm{Cr}(\mathrm{VI})$ from moist Hagerstown silt loam treated with three levels of $\mathrm{Cr}$ (III). 
Table 26. Effect of soil/solution ratio on the $\mathrm{KH}_{2} \mathrm{PO}_{4}$ extraction of Cr(VI) from moist Hagerstown silt loam. Soil/solution ratio varied by holding soil amount constant while varying $\mathrm{KH}_{2} \mathrm{PO}_{4}$ solution volume.

\begin{tabular}{ccccc}
\hline Soil Amount & $\begin{array}{c}0.01 \mathrm{M} \mathrm{KH}_{2} \mathrm{PO}_{4} \\
\text { Solution Volume }\end{array}$ & Soil/Solution & $\begin{array}{c}0.01 \mathrm{M} \mathrm{KH}_{2} \mathrm{PO}_{4} \\
\text { Extractable } \\
\text { Cr(VI) }\end{array}$ \\
\hline $\mathrm{g}$ & $\mathrm{mI}$ & $\mathrm{g} / \mathrm{ml}$ & $\mu \mathrm{g} / \mathrm{g}$ & $\mu \mathrm{g}$ \\
5 & 5.0 & 1 & 6.2 & 31 \\
5 & 10.0 & 0.5 & 8.8 & 44 \\
5 & 15.0 & 0.33 & 9.6 & 48 \\
5 & 20.0 & 0.25 & 8.8 & 44 \\
\hline
\end{tabular}


experiment, so the results of Table 26 may support the first explanation of the results shown in Figure 13 which is that not all of the $\operatorname{Cr}$ (VI) was extracted on the first extraction with $0.01 \mathrm{M} \mathrm{KH}_{2} \mathrm{PO}_{4}$ at a $1: 1$ soil/solution ratio. However, it is entirely possible that incomplete extraction was obtained the first time and subsequent extractions removed both the $\operatorname{Cr}(V I)$ missed the first time plus freshly generated $\operatorname{Cr}(V I)$. Also possible is desorption and oxidation of $\operatorname{Cr}$ (III) when a smaller soil/solution ratio was used.

In Figure 14 the results of an experiment whereby the soil/solution ratio was changed by holding the $\mathrm{KH}_{2} \mathrm{PO}_{4}$ solution volume constant and varying the amount of soil are shown. Since the amount of soil was varied, the amount of manganese oxide available for oxidizing the $\mathrm{Cr}$ was also varied. As the amount of soil increased, the amount of manganese oxide increased, and so did the amount of $\operatorname{Cr}(\mathrm{VI})$ produced. The concentration of extractable $\operatorname{Cr}(V I)$ in the soil did not vary much with soil/solution ratio when the ratio was above $1: 1$. At a ratio of $1: 1$ incomplete extraction of $\operatorname{Cr}(V I)$ again seemed likely or else desorption and oxidation of $\operatorname{Cr}$ (III) at the other ratios occurred.

In another experiment the amounts of soil and $\mathrm{KH}_{2} \mathrm{PO}_{4}$ solution were varied, but the ratio was held constant at $1: 1$. The results are diagrammed in Figure 15. As expected there was a linear increase in the amount of $\operatorname{Cr}(V I)$ extracted as the amount of soil increased. The concentration of extractable $\operatorname{Cr}(V I)$ in the soil did not vary much with the amount of soil used and theoretically should have been independent of amount. Why it was not invariant is unknown. 


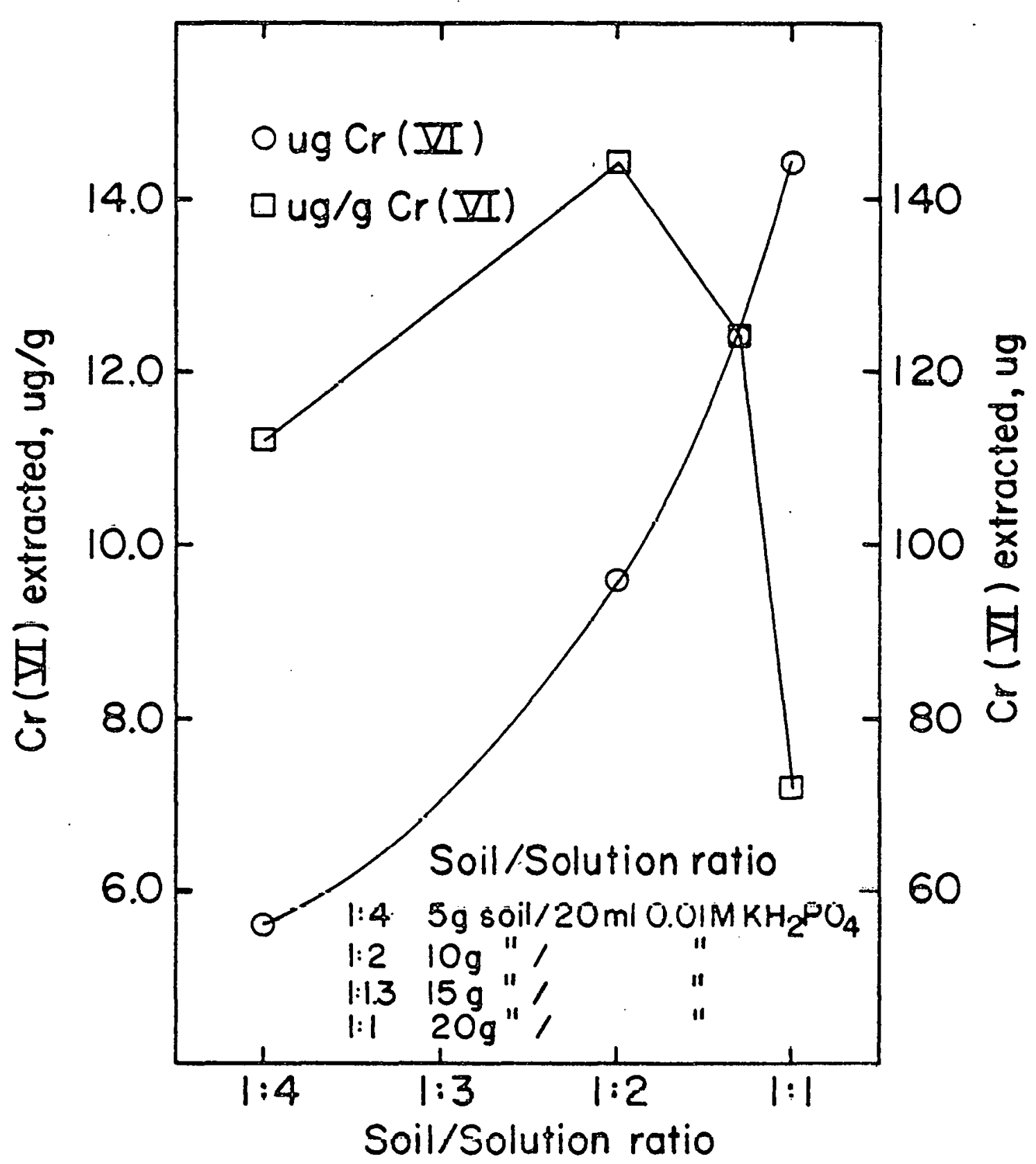

Figure 14. Effect of soil/solution ratio on $\mathrm{KH}_{2} \mathrm{PO}_{4}$ extraction of $\mathrm{Cr}$ (VI) from moist Hagerstown silt loam. Soil/solution ratio varied by holding $\mathrm{KH}_{2} \mathrm{PO}_{4}$ solution volume constant while varying soil amount. 


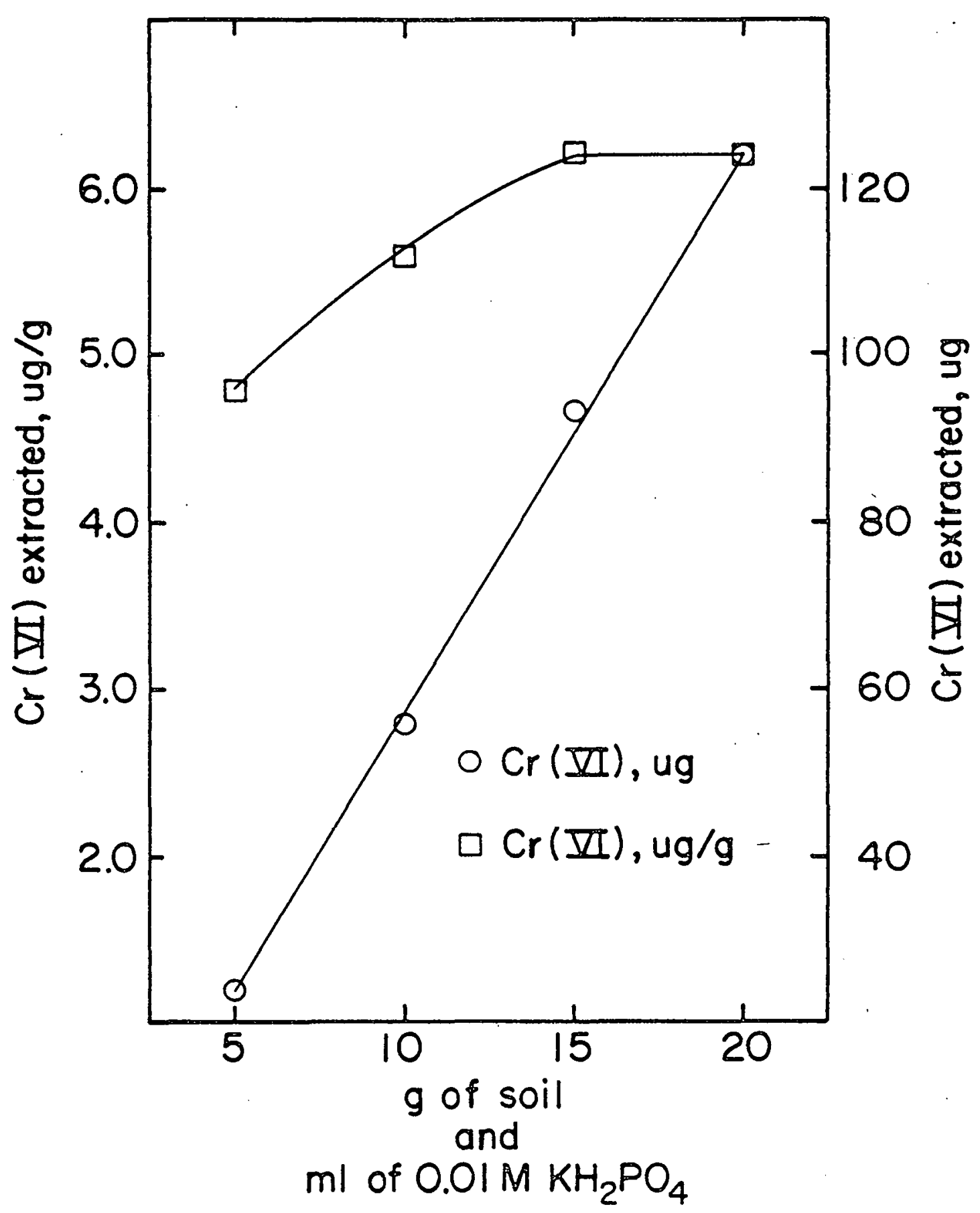

Figure 15. $\mathrm{KH}_{2} \mathrm{PO}_{4}$ extraction of $\mathrm{Cr}(\mathrm{VI})$ from moist Hagerstown silt loam at constant soil/solution ratios. 


\section{Oxidation of $\mathrm{Cr}$ from Different Sources at Selected}

\section{Concentrations in Soil with Time}

In addition to the experiments already described a series of incubation experiments were run to study the effects of $\operatorname{Cr}$ (III) source and amount on $\mathrm{Cr}$ oxidation with time. In the first of these, the oxidation of three levels of $\operatorname{Cr}$ (III) added to Murrill soil was followed over a period of $29 \mathrm{hr}$ by determining $\operatorname{Cr}(\mathrm{VI})$ in the soil solution extracted using an immiscible displacement-centrifugation technique (Mubarak and 0.1sen, 1976) and by determining $0.01 \mathrm{M} \mathrm{KH}_{2} \mathrm{PO}_{4}$ extractable $\mathrm{Cr}(\mathrm{VI})$. The results are summarized in Table 27, At the lowest rate of added (r. (TTT) there was little change in the amount of soil solution $\mathrm{Cr}(\mathrm{VI})$ or $\mathrm{KH}_{2} \mathrm{PO}_{4}$ extractable $\operatorname{Cr}(V I)$ over a period of a day. The oxidation of $\operatorname{Cr}$ (III) apparently occurred rapidiy, reaching the maximum in the first couple of hours before any samples were taken. At the two higher rates of added $\mathrm{Cr}$ (III) there was an increase in soil solution $\mathrm{Cr}(\mathrm{VI})$ and $\mathrm{KH}_{2} \mathrm{PO}_{4}$ extractable $\operatorname{Cr}(V I)$ with time. Most of the $\operatorname{Cr}(V I)$ produced was produced during the first couple of hours with the next largest increase occurring between 7 and 26 to $29 \mathrm{hrs}$. Again, as with previously described experiments only a small fraction of added $\mathrm{Cr}$ was oxidized. Most of the rest was presumably sorbed to various soil components and unavailable for oxldar1on. Again, most, but not all of the soil solution $\operatorname{Cr}$ was $\mathrm{Cr}(\mathrm{VI})$. At the lowest level of added $C r$ virtually all the soil solution $C r$ was $\mathrm{Cr}(V I)$, but as the amount of added $\operatorname{Cr}$ (III) was increased, the fraction of soil solution $C r$ existing as $\operatorname{Cr}(V I)$ decreased. Even though there was more than enough manganese oxide in the suil to uxidize all of the soil solution $\mathrm{Cr}$, complete oxidation was not achieved indicating that all of the manganese oxide was not accessible to the $\mathrm{Cr}$. Or perhaps reduction 
Table 27. Effect of varying $\operatorname{Cr}$ (III) concentration on the oxidation of $\mathrm{Cr}$ in moist Murrill silt loam with time.

$\underline{0.01 \mathrm{M} \mathrm{KH}_{2} \mathrm{PO}_{4} \text { Extractable } \mathrm{Cr}(\mathrm{VI})}$

\begin{tabular}{|c|c|c|c|c|c|}
\hline \multirow[b]{2}{*}{$\operatorname{Cr}($ III $)$} & \multicolumn{5}{|c|}{ Time, hrs } \\
\hline & 2.5 & 4.5 & 7.5 & 15.5 & 29 \\
\hline 10 & 0.78 & 0.51 & 0.56 & 0.60 & 0.49 \\
\hline 50 & 2.71 & 1.93 & 2.93 & 2.91 & 4.64 \\
\hline 100 & 3.60 & 4.57 & 4.45 & 6.08 & 6.88 \\
\hline
\end{tabular}

Soil Solution $\operatorname{Cr}(\mathrm{VI})$

\begin{tabular}{|c|c|c|c|c|}
\hline \multirow[b]{2}{*}{ Cr(III) Added } & \multicolumn{4}{|c|}{ Time, hrs } \\
\hline & 5 & 6.5 & 8 & 26 \\
\hline$\mu \mathrm{g} / \mathrm{g}$ & $-\cdots$ & -- & & -- \\
\hline 10 & 0.67 & 0.53 & 0.50 & 0.53 \\
\hline 50 & 1.88 & 1.80 & 2.41 & 2.45 \\
\hline 100 & 3.69 & 3.41 & 3.59 & 4.65 \\
\hline
\end{tabular}

Soil Solution Total $C$ r

$\underline{\operatorname{Cr} \text { (III) Added }}$

$\mu \mathrm{g} / \mathrm{g}$

10

0.68

0.52

0.55

0.58

50

2.20

2.11

2.83

2.77

100

5.04

5.18

4.46

5.94 
of $\operatorname{Cr}(\mathrm{VI})$ by the soil organic matter was also occurring. This matter will be considered later. The $0.01 \mathrm{M} \mathrm{KH}_{2} \mathrm{PO}_{4}$ extractable $\mathrm{Cr}(\mathrm{VI})$ in this experiment actually included soil solution $\operatorname{Cr}(\mathrm{VI})$ as well as $\operatorname{Cr}(\mathrm{VI})$ sorbed to the soil, since wet soils were extracted. At the lowest level of added $\mathrm{Cr}$ soil solution $\mathrm{Cr}(\mathrm{VI})$ accounted for about $50 \%$ of the extractable $\operatorname{Cr}(V I)$ while at the highest level it accounted for about $30 \%$ of the extractable $\operatorname{Cr}(V I)$.

The results in Table 27 suggest rapid oxidation of $\operatorname{Cr}$ (III), hut no samples were taken before $2: 5 \mathrm{hrs}$ of incubation. Therefore, another experiment wac run to Jtudy the oxidatiun of $C_{I}$ ln Murrill sile loam over a shorter time span. The results of this experiment are presented in Figure 16. The chief difference between this experiment and the previous one was in the water content $(50 \%$ for the previous experiment, $100 \%$ for this one), but this should not have made much difference. The

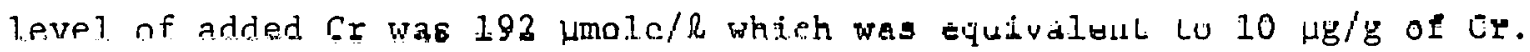
The graph shows that the fastest rate of $\mathrm{Cr}$ oxidation occurred rather early on (less than $1 \mathrm{hr}$ ). Between 2 and 4 hrs only a small increase in $\operatorname{Cr}(V I)$ was observed.

It was also desirable to compare the oxidation of $\mathrm{Cr}$ from different sources at different levels of added $C_{r}$ and to follow the $C_{r}$ over a longer time span. Such an experiment was carried out using Hagerstown silt loam and is summarized in Table 28 . The oxidation of the relatively soluble $\mathrm{CrCl}_{3}$ was compared to the oxidation of the relatively insoluble $\mathrm{Cr}(\mathrm{OH})_{3}$. The more readily soluble compound was more easily oxidized as expected, but the important point is that even a compound like $\mathrm{Cr}(\mathrm{OH})_{3}$ which would normally be considered insoluble in soil was oxidized to a small degree. This has implications for the land disposal of wastes 


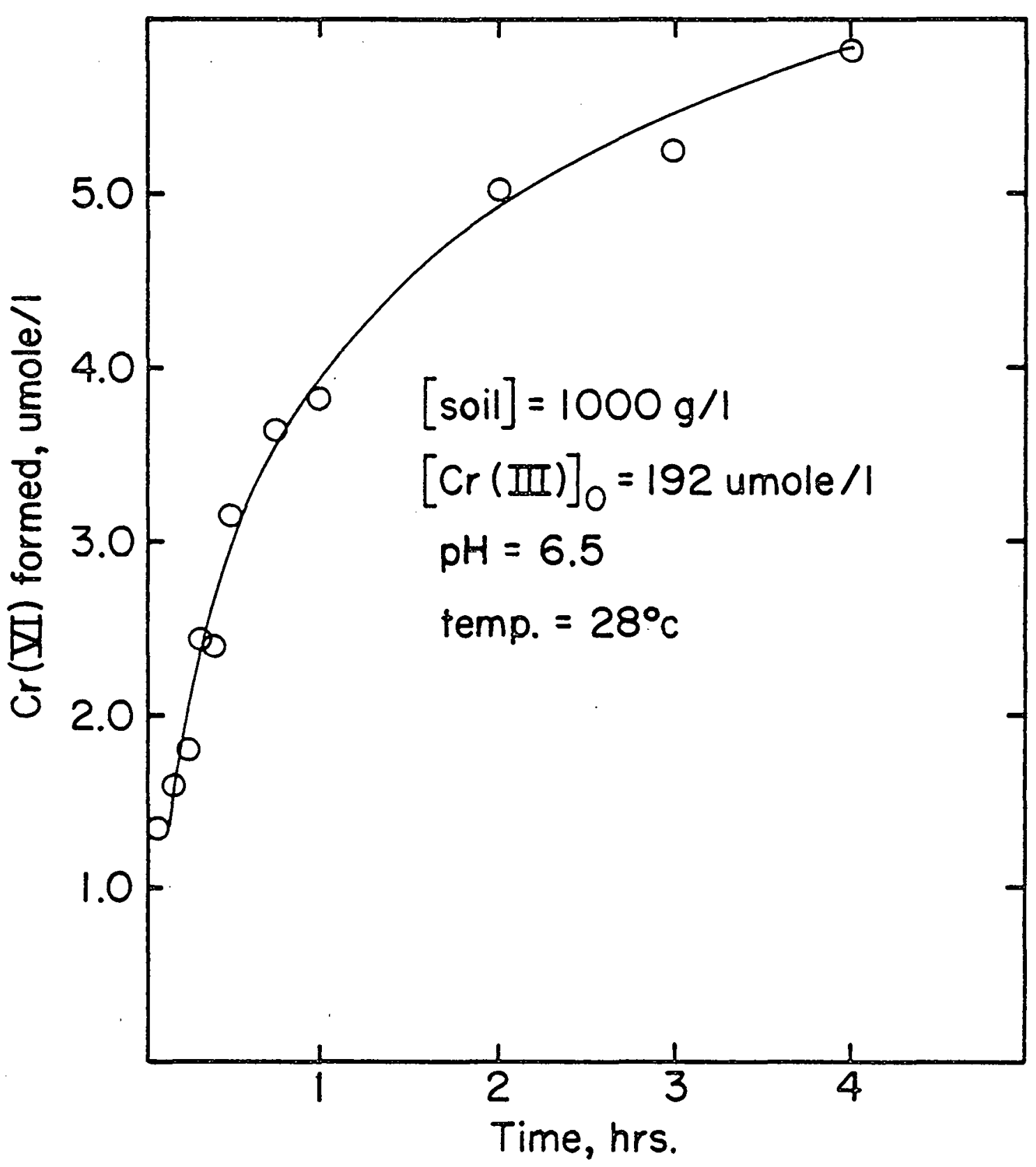

Figure 16. Kinetics of $\mathrm{Cr}$ oxidation in moist Murrill silt loam. 
Table 28. Effect of $\mathrm{Cr}$ (III) source and amount on the oxidation of $\mathrm{Cr}$ in moist Hagerstown silt loam with time.

$0.01 \mathrm{M} \mathrm{KH}_{2} \mathrm{PO}_{4}$ Extractable $\mathrm{Cr}$ (VI)

\begin{tabular}{|c|c|c|c|c|}
\hline \multirow[b]{2}{*}{ Cr Source } & \multirow[b]{2}{*}{ Cr Added } & \multicolumn{3}{|c|}{ Time } \\
\hline & & 1 Day & 1 Week & 1 Month \\
\hline \multirow[t]{2}{*}{$\mathrm{CrCl}_{3}$ solution } & 10 & 0.85 & 0.07 & 0.07 \\
\hline & 100 & 6.40 & 2.00 & 0.07 \\
\hline \multirow[t]{2}{*}{$\overline{\mathrm{Cr}}(\mathrm{OH})_{3}$ suspension } & 10 & 0.10 & 0.00 & 0.02 \\
\hline & 100 & 1.65 & 0.45 & 0.05 \\
\hline
\end{tabular}

Soil Solution $\operatorname{Cr}(V I)$

\begin{tabular}{|c|c|c|c|c|}
\hline \multirow[b]{2}{*}{ Cr Source } & \multirow[b]{2}{*}{ Cr $\Lambda$ dded } & \multicolumn{3}{|c|}{ Time } \\
\hline & & $1 \mathrm{Day}$ & 1 Wock & I Month \\
\hline & $\mu g / g$ & $\cdots-\cdots$ & $--\mu \mathrm{g} / \mathrm{m}]$ & $\cdots$ \\
\hline \multirow[t]{2}{*}{$\mathrm{CrCl}_{3}$ solution } & 10 & 0.56 & 0.20 & 0.01 \\
\hline & 100 & 5.56 & 3.20 & 0.15 \\
\hline \multirow[t]{2}{*}{$\operatorname{rr}(\cap H))_{\text {y sllapenainn }}$} & $1 n$ & 0.07 & 0.01 & $n \cdot n n$ \\
\hline & 100 & 1.11 & 0.80 & 0.06 \\
\hline
\end{tabular}


from the metal finishing industry. Such wastes normally consist of metals precipitated as the hydroxides including $\mathrm{Cr}(\mathrm{OH})_{3}$. It might be surmised that such wastes could safely be disposed of on soil because of low solubility, but the results in Table 28 indicate otherwise, since $\mathrm{Cr}$ (VI) from the oxidation of $\mathrm{Cr}(\mathrm{OH})_{3}$ in soil would be toxic to plants, aquatic life, and possibly humans. Again, the amount of $\mathrm{Cr}$ oxidized in this experiment amounted to only a small fraction of the total, but measurable levels persisted for a period of at least a month. It appeared that the maximum level of $\operatorname{Cr}(\mathrm{VI})$ that was reached occurred in about a day and the decline in $\operatorname{Cr}(V I)$ after that was due to reduction by organic matter. Using some of the $\mathrm{KH}_{2} \mathrm{PO}_{4}$ extractable $\mathrm{Cr}(\mathrm{VI})$ data the half-life for $\operatorname{Cr}(V I)$ reduction was estimated to be 8 days. Using some of the soil solution $\operatorname{Cr}(V I)$ data the half-life for $\operatorname{Cr}(V I)$ reduction was estimated to be 17 days. It is apparent that $\mathrm{Cr}$ oxidation was fairly rapid while. $\operatorname{Cr}$ reduction was slow. This will be examined in detail later.

The oxidation of the very insoluble $\mathrm{Cr}_{2} \mathrm{O}_{3}$ in moist Hagerstown silt loam was also examined and the results are listed in Table 29. A high level of $\mathrm{Cr}_{2} \mathrm{O}_{3}^{\prime}$ was used representing a severe contamination situation. Small amounts of $\operatorname{Cr}(V I)$ were found over an 11 -month period. When an insoluble $\mathrm{Cr}$ compound is added to moist soil a source of oxidizable $\mathrm{Cr}$ is provided for a long period of time and oxidation will occur as long as the manganese oxide supply holds out. Thus, caution is urged in the land disposal of inorganic $\mathrm{Cr}$ compounds.

The incubation experiments implied that the oxidation of $\mathrm{Cr}$ is fairly rapid and that reduction is slow. A series of kinetic experiments 
Table 29. Potassium phosphate extractable $\operatorname{Cr}(\mathrm{VI})$ in moist Hagerstown silt loam amended with $\mathrm{Cr}_{2} \mathrm{O}_{3}$.

\begin{tabular}{lcrccc}
\hline & & \multicolumn{4}{c}{ Time } \\
\cline { 3 - 6 } Cr Source & Cr Added & 1 Week & 1.5 Months 5 Months 11 Months \\
\hline & $m g / g$ & - & 0.04 & 0.60 & 0.52 \\
$\mathrm{Cr}_{2} \mathrm{O}_{3}$ & 68.4 & 0.96 & 1.04 & \\
\hline
\end{tabular}


was designed in order to study these reactions in more detail and the results of these experiments are described next.

\section{Kinetics of $\mathrm{Cr}$ Oxidation and Sorption by}

\section{Moist Hagerstown Silt Loam}

Sorption reactions are normally considered to be quite rapid--too fast to even measure. In Figure 17 the sorption of $\operatorname{Cr}$ (III) by a suspension of moist Hagerstown silt loam with time is shown. As expected the sorption reaction was too rapid to measure and was complete in 30 sec when the first sample was taken. No change in solution total Cr was observed over the period of $30 \mathrm{sec}$ to $15 \mathrm{~min}$.

The kinetics of $\mathrm{Cr}$ oxidation as affected by temperature in a dilute suspension of Hagerstown silt loam are shown in Figure 18. The suspension concentration used in this experiment was considerably less than that used in the incubation experiments. Therefore, this experiment was analogous to $\mathrm{Cr}$ contaminating a sediment-laden stream or river. In the incubation experiments the amount of manganese oxide was far in excess of that needed to oxidize all the added $\mathrm{Cr}$. In this experiment the amount of soil used was such that its reducible Mn content was just enough to oxidize all of the added $\mathrm{Cr}$. Of course not all of the manganese oxide was accessible to the $\mathrm{Cr}$ and about half of the added $\mathrm{Cr}$ was sorbed and unavailable for oxidation, so the actual amounts able to react differed from the theoretical maximum. As with the incubation experiments most of the oxidation occurred during the first hour with only small increases observed after that. It is clear from the figure that temperature exerts a major effect on $C r$ oxidation in soil. At low temperature $\left(2^{\circ} \mathrm{C}\right)$ the oxidation of $\mathrm{Cr}$ was following zero order kinetics 


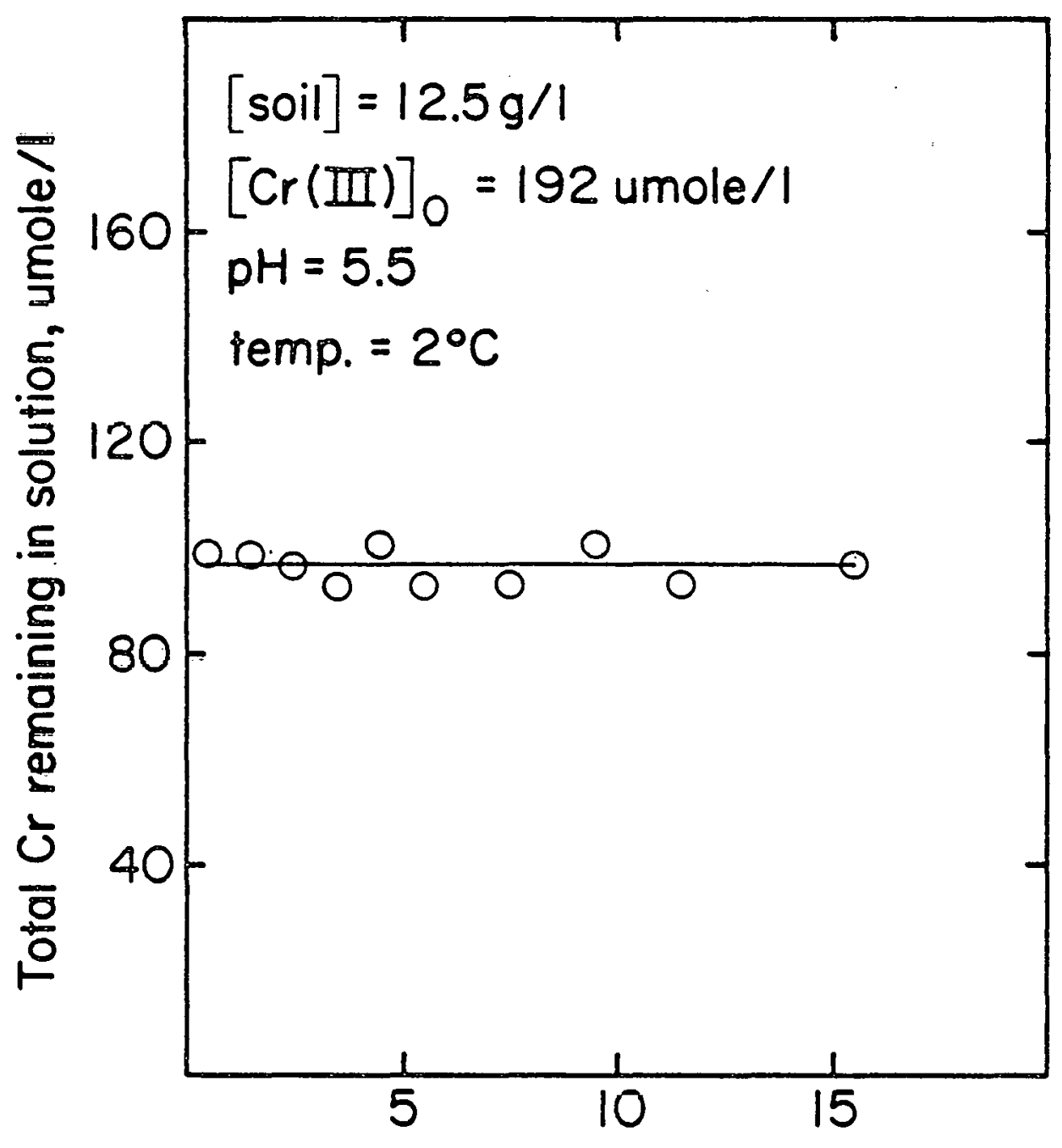

Time, $\min$.

Figure 17. Kinetics of $\mathrm{Cr}$ sorption by moist Hagerstown silt loam. 


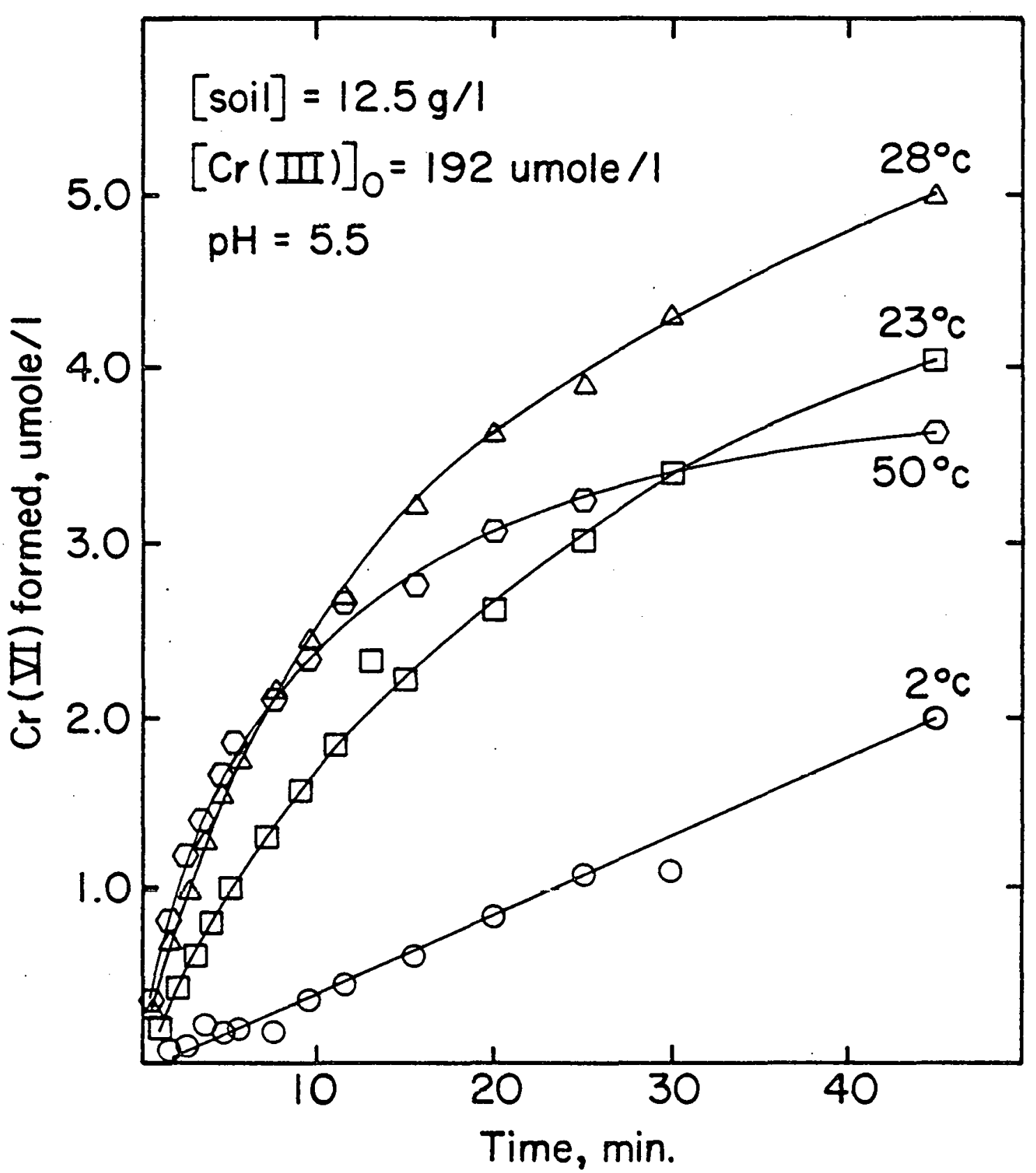

Figure 18. Effect of temperature on the kinetics of $\mathrm{Cr}$ oxidation in moist Hagcrstown silt loam. 
$([\mathrm{Cr}(\mathrm{VI})]$ plotted against time yielded a straight line) with a rate coefficient of $0.046 \mu \mathrm{mole} / \mathrm{l} / \mathrm{min}$. Beyond about $1 \mathrm{hr}$ deviations from the straight line were observed. Zero order kinetics in which the rate of the reaction does not depend upon the concentrations of reactants are not unusual for reactions involving surfaces. In the present case at low temperature the oxidation reaction was sufficiently slowed down so that the manganese oxide surface was "saturated" with $\mathrm{Cr}$ undergoing oxidation. Higher concentrations of $\operatorname{Cr}$ (III) will not speed up the reaction, since the reaction can only proceed as fast as the amount of manganese oxide surface available for oxidation will allow. At higher temperatures an initial rapid increase in $\operatorname{Cr}(V I)$ was quickly followed by a fall-off in reaction rate. The fall-off was greater at a higher temperature. There are two possible explanations for this observation. One is that side-reactions involving $\operatorname{Cr}(\mathrm{VI})$ became more important as time goes on and were more important at higher temperatures. The other explanation is that not all of the manganese oxide was available for oxidation and the surface was "used up" as the reaction proceeded, or perhaps both situations were occurring. In any case as with the incubation experiments the reaction "shuts off" before reaching the maximum allowable amount of $\operatorname{Cr}(V I)$ produçed if all the soil manganese nxide was used up. More will be said about this later.

The effect of removing organic matter on the kinetics of $\mathrm{Cr}$ oxidation by moist Hagerstown silt loam was also examined and the results are illustrated in Figure 19. Th1s experiment revealed that organic matter removal did increase the rate of reartion whereas in the $6 r$ oxidation test no difference was found between untreated Hagerstown silt loam and Hagerstown treated to remove organic matter. The $\mathrm{Cr}$ oxidation 


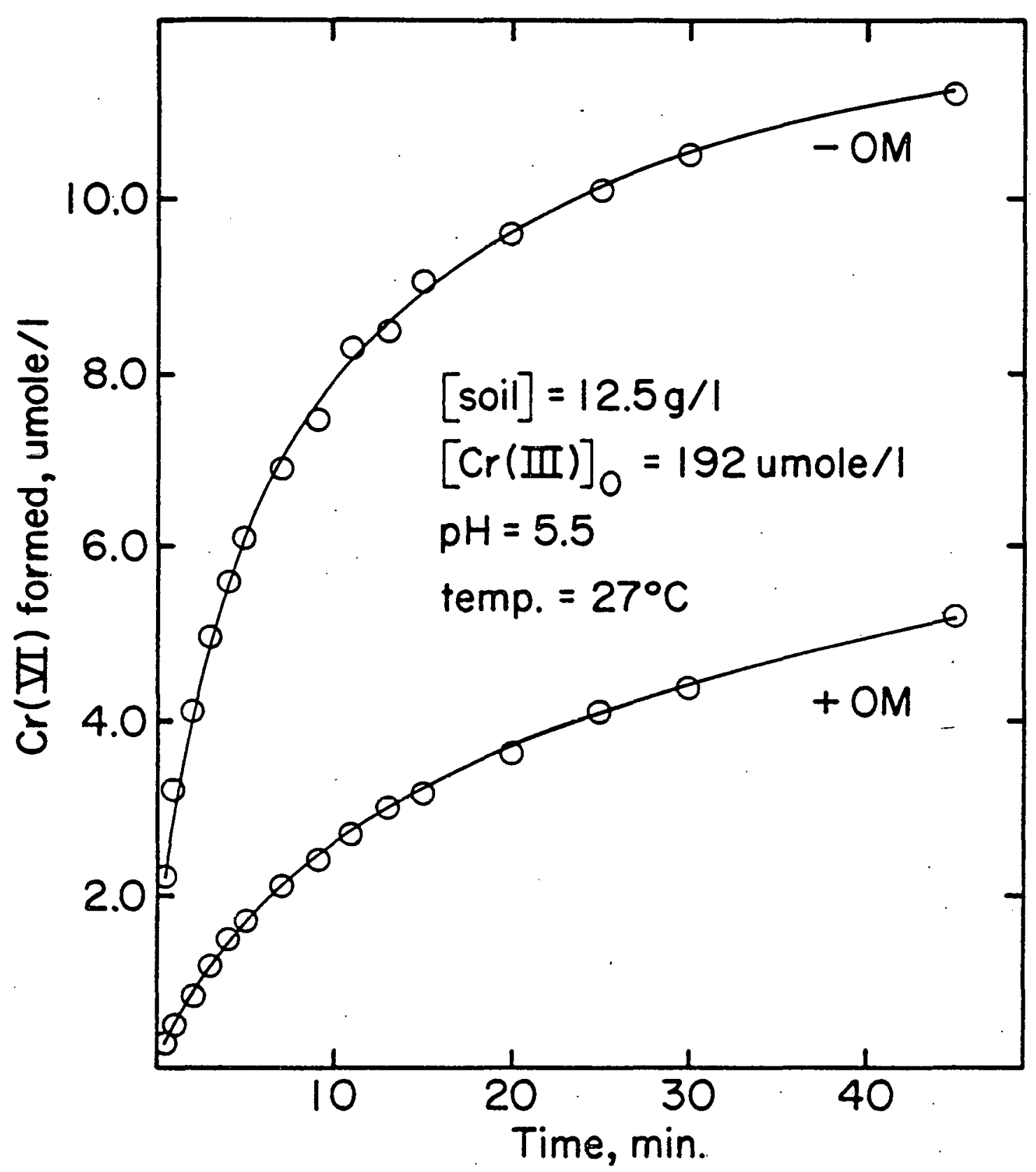

Figure 19. Effect of organic matter removal on the kinetics of $\mathrm{Cr}$ oxidation in moist Hagerstown silt loam. 
test used a 15 min shaking time so any differences would have had time to show up. The discrepancy between the two results may be due to the amount of soil used. In the $\mathrm{Cr}$ oxidation test an excess of soil theoretically needed to oxidize all of the added $\mathrm{Cr}$ was used. Perhaps this was enough to mask any differences. Another explanation would be that all of the $\mathrm{NaOCl}$ used to destroy the organic matter was not washed out of the soil used in the kinetic experiment. Sodium hypochlorite is capable of oxidizing $\mathrm{Cr}$ so the results in Figure 19 may actually be an experimental artifact and not a real difference at all. Further work to settle this matter is needed.

\section{Kinetics of $\mathrm{Cr}$ Oxidation by $\mathrm{MnO}$ Minerals}

Experiments on the kinetics of $\mathrm{Cr}$ oxidation in moist soil are clouded by the sorption and reduction reactions involving $\mathrm{Cr}$ and other soil components. To avoid this problem the oxidation of $\mathrm{Cr}$ by manganese oxide minerals was studied and the results of these experiments are now discussed. Most of the experiments made use of $\delta-\mathrm{MnO}_{2}$, a hydrated,

amorphous form of $\mathrm{MnO}_{2}$ thought to be the most common $\mathrm{MnO}_{2}$ mineral in the environment.

The effect of temperature on $\mathrm{Cr}$ oxidation by $\delta-\mathrm{MnO}_{2}$ was studied first and the results are shown in Figure 20. The general shape of the kinetic curves was the same as the soil kinetic curves, an initial rapid oxidation of $\mathrm{Cr}$ followed by a rapid fall-off in oxidation rate. Both the rate and the amount oxidized increased with temperature. Even though there was a large excess of $\delta-\mathrm{MnO}_{2}$ used, the reaction did not go to completion, that is, all of the $\operatorname{Cr}($ III) was not used up. This rapid fall-off in the reaction rate and lack of complete oxidation could only occur if the surface of the $\delta-\mathrm{MnO}_{2}$ available for oxidizing $\mathrm{Cr}$ was 


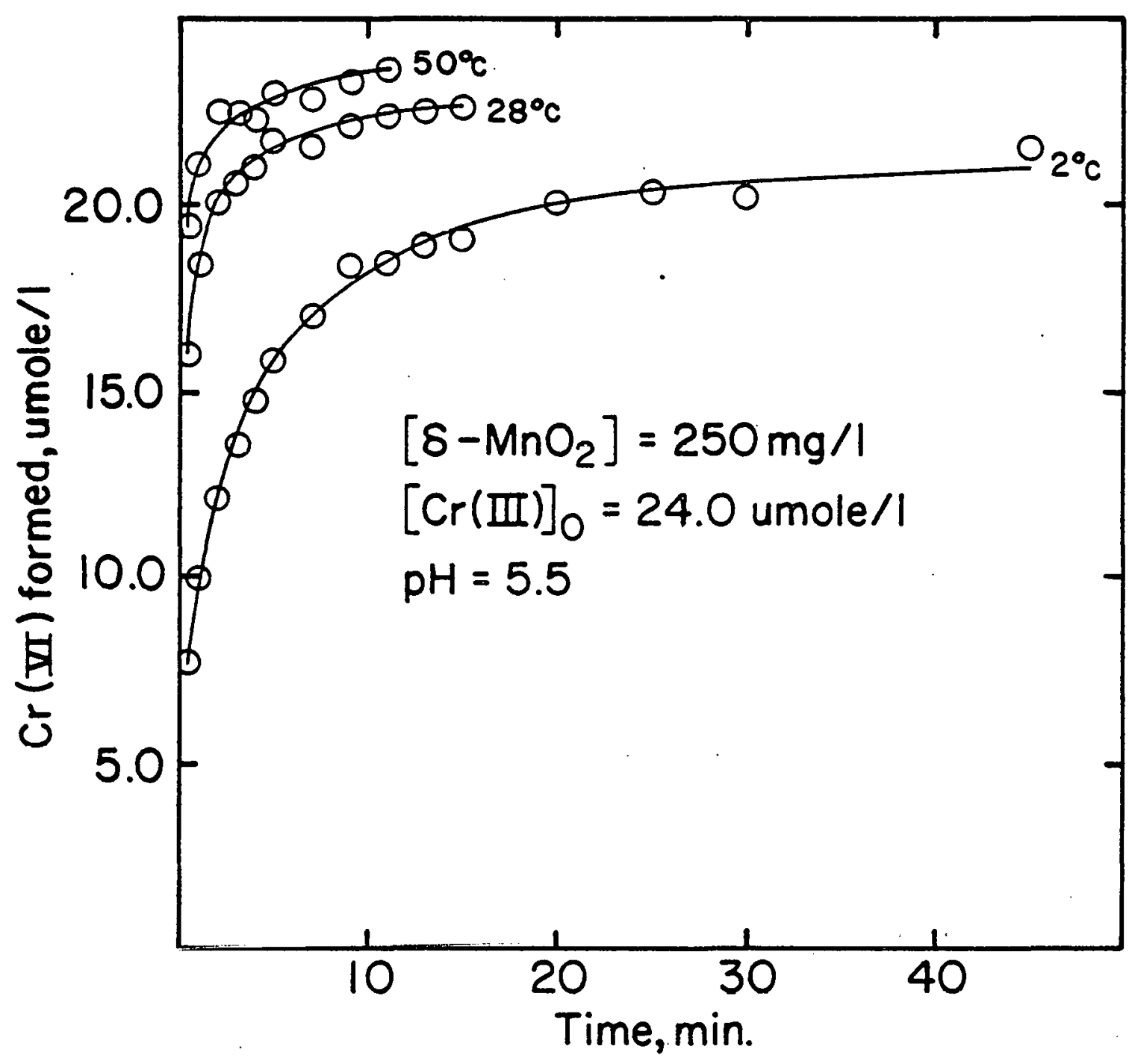

Figure 20. Effect of temperature on the kinetics of $\mathrm{Cr}$ oxidation by $\delta-\mathrm{MnO}_{2}$ at $\mathrm{PH} 5.5$. 
"used-up" as the reaction proceeded. However, there should have been more than enough surface area available to complete the reaction. An explanation of the observed results can be inferred by consideration of what happened to the Mn reduced during the reaction. As $\operatorname{Cr}$ was oxidized Mn (IV) was reduced to Mn(II). However, instead of being released to solution and exposing fresh $\mathrm{Mn}$ (IV) for oxidizing $\mathrm{Cr}$, the $\mathrm{Mn}$ (II) was retained on the surface, thus blocking access to the Mn(IV) below it. This explanation is strongly supported by not finding any increase in the $\mathrm{Mn}$ (II) content of the solution surrounding the $\mathrm{MnO}_{2}$ as the reaction proceeded. Morgan and Stumn (1964) and Posselt et al. (1968) have found that $\delta-\mathrm{MnO}_{2}$ has a high affinity for its own divalent metal ion. Protons are also a product of the reaction between $\delta-\mathrm{MnO}_{2}$ and $\mathrm{Cr}$ and these would also be retained on the surface, thus blocking access to fresh Mn(IV). During the reaction it was found that no $\mathrm{Cr}$ was sorbed to the $\delta-\mathrm{MnO}_{2}$ surface, since all of the added $C_{r}$ was found in solution at any point in time. Thus, Cr(III) only forms a "loose" association with the surface while being oxidized and oxidation occurs so quickly that it is rapidly released. The negatively charged chromate ions are repelled by the negatively charged $\delta-\mathrm{MnO}_{2}$ surface. This lack of sorption of $\mathrm{Cr}$ on $\delta-\mathrm{MnO}_{2}$ is in dramatic contrast to the known high affinity of $\delta-\mathrm{MnO}_{2}$ for cations such as Co, Cu, Zn, and Cd. (Morgan and Stumm, 1964; Posselt et al., 1968; Murray et al., 1968; Loganathan and Burau, 1972). An excess of $\mathrm{d}-\mathrm{MnO}_{2}$ needed to oxidize all the $\mathrm{Cr}(\mathrm{III})$ was used in this experiment to try and determine the reaction order for formation of $\operatorname{Cr}(V I)$. However, it is obvious that the reaction was much too fast when $\delta-\mathrm{MnO}_{2}$ actually was in excess for the experimental technique to follow. Fast flow or instrumental techniques must be used. It is also clear that predicted 
levels of $\operatorname{Cr}(V I)$ will probably never be achieved in soils if the manganese oxide surface area is limiting. This is a most fortunate occurrence, since severe environmental contamination with $\operatorname{Cr}$ (VI) would occur and would probably already have been observed. The effect of $\delta-\mathrm{MnO}_{2}$ amount on $\mathrm{Cr}$ oxidation will be reconsidered later.

It might be worthwhile to ask what is the effect of $\mathrm{pH}$ on $\mathrm{Cr}$ oxidation by $\delta-\mathrm{MnO}_{2}$. Bartlett and James (1979) had discovered that the amount of $\mathrm{Cr}$ oxidized in soil increased with decreasing $\mathrm{pH}$. The effect of $\mathrm{pH}$ on $\mathrm{Cr}$ oxidation by $\mathrm{\delta}-\mathrm{MnO}_{2}$ is shown in Figure 21. At low $\mathrm{pH}$ the rate of $\mathrm{Cr}$ oxidation was less than the rate at higher more environmentally realistic $\mathrm{pH}$ levels. At $\mathrm{pH} 1$ the rate of oxidation is approaching a zero order level qualitatively similar to the case with soil at $2^{\circ} \mathrm{C}$. The reason the rate is slowed down at low $\mathrm{pH}$ can be explained on the basis of the zero point of charge (ZPC) of the $\delta-\mathrm{MnO}_{2}$. The zero point of charge is the $\mathrm{pH}$ at which a surface is electrically neutral and will not migrate to a cathode or an anode when an electrical potential is applied to the suspension. For $\delta-\mathrm{MnO}_{2}$ the zero point of charge is about $\mathrm{pH} 2.5$. Above this the mineral carrtes a net negative charge due to $\mathrm{OH}^{-}$ groups at the mineral surface and below this the mineral carries a net positive charge. At $\mathrm{pH} 1$ the mineral carried a net positive charge due to excess protons. These tended to repel the $C r$ thus slowing down the rate of reaction because the $C r$ had to replace the protons before the oxidation could occur. At $\mathrm{pH} 3$ (slightly above the $\mathrm{ZPC}$ ) the rate of oxidation increased, but was still slowed down somewhat. At pH 5.5 to 7.5 the rate was not significantly affected by $\mathrm{pH}$. At first it might seem that this evidence contradicts the Bartlett and James data. However, the increase in $\mathrm{Cr}$ oxidation at low $\mathrm{pH}$ in soils might simply be 


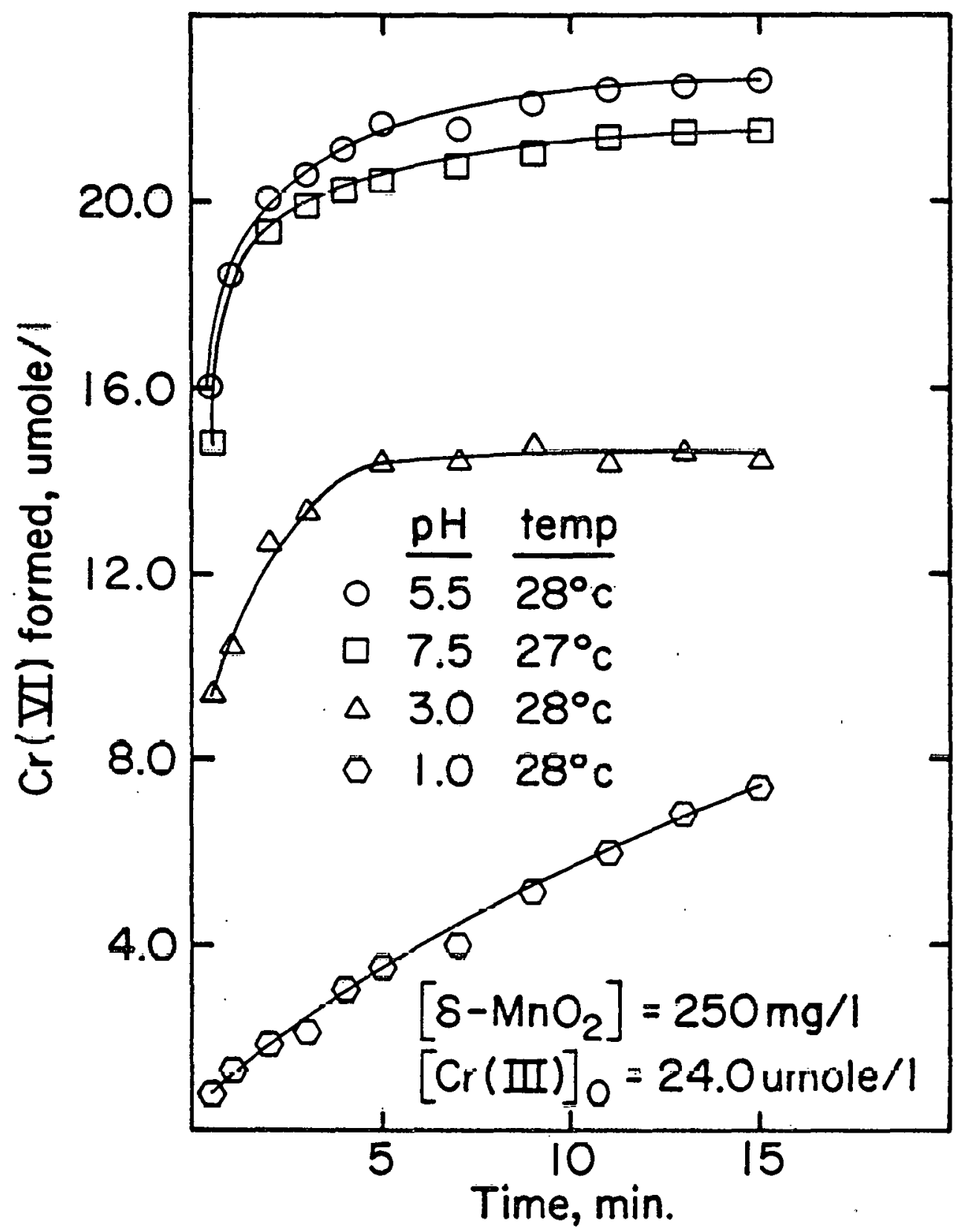

Figure 21. Effect of $\mathrm{pH}$ on the kinetics of $\mathrm{Cr}$ oxidation by $\delta-\mathrm{MnO}_{2}$. 
due to less sorption or precipitation of $\mathrm{Cr}$ at low $\mathrm{pH}$. More $\mathrm{Cr}$ remains in solution to be oxidized. It seems that the effect of $\mathrm{pH}$ on $\mathrm{Cr}$ oxidation is indirect, controlling sorption and solubility rather than a direct control of oxidation at least at environmentally meaningful $\mathrm{pH}$ levels.

In Figure 22 the effect of temperature on $\mathrm{Cr}$ oxidation by $\delta-\mathrm{MnO}_{2}$ at $\mathrm{pH} 1$ is shown. A huge excess of $\delta-\mathrm{MnO}_{2}$ was maintained. At low temperature the reaction was sufficiently slowed down to follow zeroorder kinetics. However, a low $\mathrm{pH}$ was needed to slow the reaction down even at this low temperature which is in contrast to the case with the soil. At room temperature the reaction began by following zero-order kinetics but fell off as the mineral surface was "used up". At high temperature the reaction occurred so quickly that the mineral surface was rapidly "used up". However, at higher temperatures the thermal motion allows more of the surface to be used than at the lower temperature. Thus, the amount of $\mathrm{MnO}_{2}$ surface available for oxidation is temperature dependent. The rate coefficients were $0.31 \mu$ mole/ $/ \mathrm{min}$ at $2^{\circ} \mathrm{C}$ and $2.61 \mu \mathrm{mole} / \mathrm{l} / \mathrm{min}$ at $24^{\circ} \mathrm{C}$. The activation energy was 14.9 $\mathrm{kcal} / \mathrm{mole}$.

The metal finishing industry often relies on precipitating out metals in their wastewater as hydroxides and then disposes of the metal hydroxide sludge. As already seen $\mathrm{Cr}(\mathrm{OH})_{3}$ can be oxidized in soil. One might ask what is the rate of oxidation of $\mathrm{Cr}(\mathrm{OH})_{3}$ by $\delta-\mathrm{MnO}_{2}$ at high $\mathrm{pH}$ and such a curve is shown in Figure 23. Although much slower than the oxidation of $\mathrm{CrCl}_{3}$ at lower $\mathrm{pH}$ levels, the oxidation of $\mathrm{Cr}(\mathrm{OH})_{3}$ at high $\mathrm{pH}$ could pose a problem in the land disposal of such a waste. Caution is urged in this matter. 


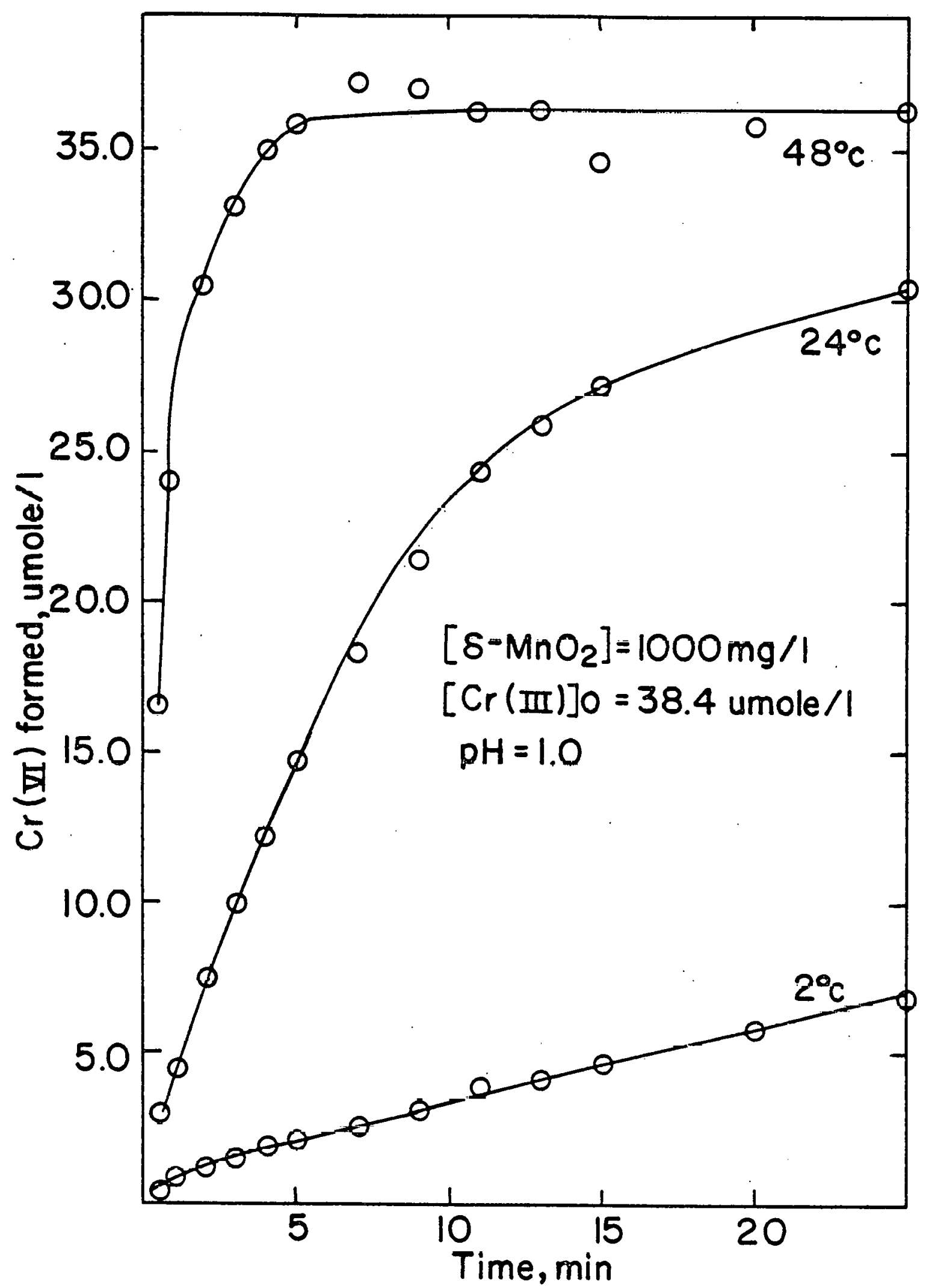

Figure 22. Effect of temperature on the kinetics of $\mathrm{Cr}$ oxidation by $\delta-\mathrm{MnO}_{2}$ at $\mathrm{pH} 1.0$. 


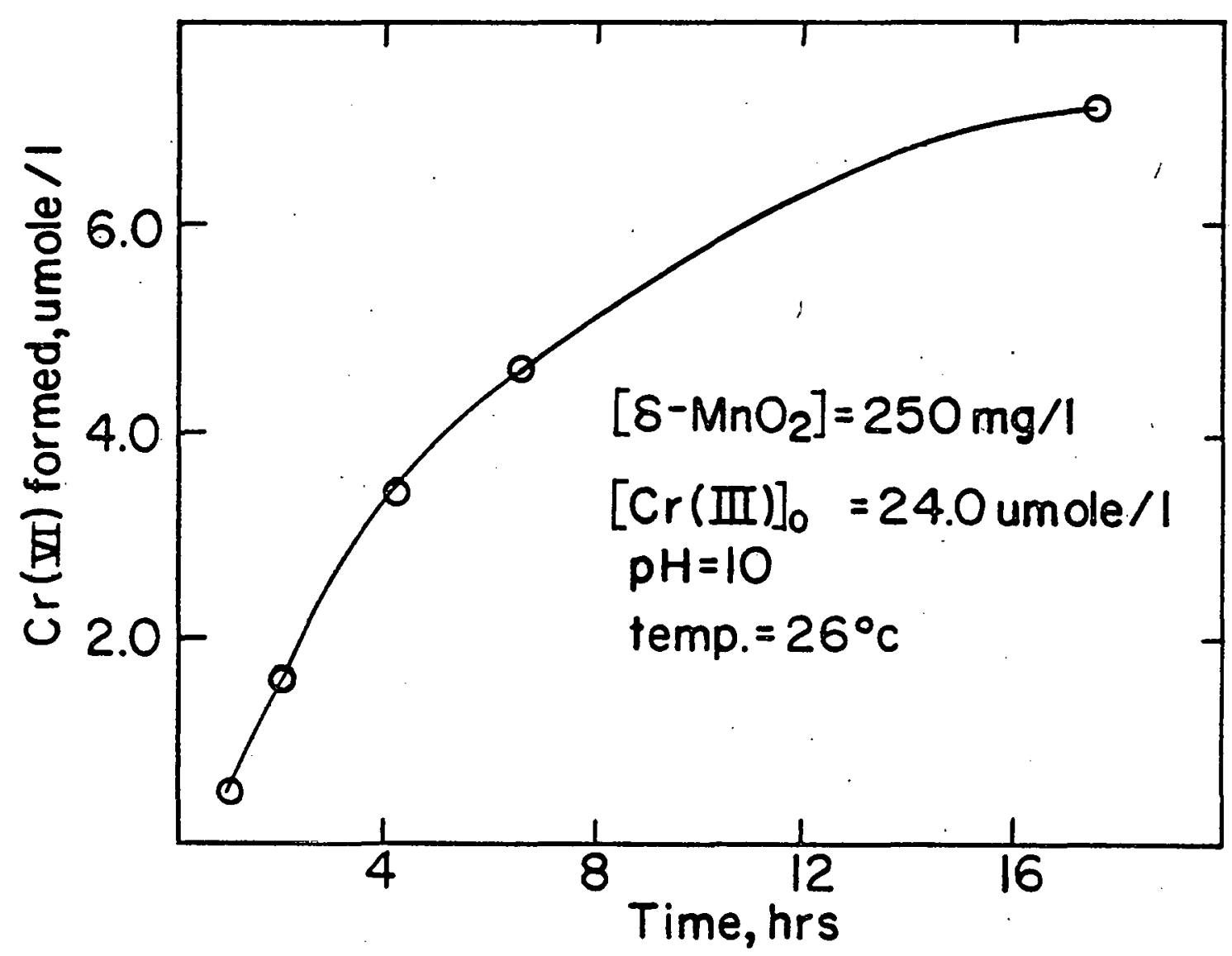

F1gure 23. Kinerigs of $\mathrm{Cr}(\mathrm{OH})_{3}$ oxidation by $8-\mathrm{H}_{2} \mathrm{O}_{2}$ at pH 10 . 
The effect of ionic strength on the rate of $\mathrm{Cr}$ oxidation was also examined and the results are presented in Figure 24. As expected an increase in solution fonic strength lowered the oxidation rate due to a decrease in the ionic activity of $\operatorname{Cr}($ III). However, the effect was a small one and could be ignored in dilute solutions.

The effects of solution composition on the rate of $\mathrm{Cr}$ oxidation are shown in Figure 25. The previously described experiments all used a $10^{-3} \mathrm{M} \mathrm{NaClO}_{4}$ solution for suspending the $\delta-\mathrm{MnO}_{2}$. However, wastewaters and soil solutions are not dilute perchlorate solutions, so the effect of different solution compositions on oxidation rate must be known. Using a solution containing $\mathrm{KCl}, \mathrm{MgCl}_{2}$, and $\mathrm{CaCl}_{2}$ to approximate the "average" soil solution, it can be seen that the oxfdation rate was substantially decreased initially. However, this decrease was certainly not enough to lead one to expect to observe much of an effect "in the field", since most of the $\mathrm{Cr}$ was oxidized within 15 min anyway. Adding other metal salts decreased the rate only slightly more. Adding DTPA, a chelating agent, decreased the rate substantially. Probably because the DTPA lowered the $\operatorname{Cr}$ (III) activity substantially and also may have affected the $\delta-\mathrm{MnO}_{2}$ surface. Natural chelators would be expected to also slow down the oxidation rate. When the $\delta-\mathrm{MnO}_{2}$ was suspended in a $1000 \mu \mathrm{g} / \mathrm{ml}$ Fe(III) solution and the $\mathrm{pH}$ raised to 5.5 , the Fe(III) precipitated as $\mathrm{Fe}(\mathrm{OH})_{3}$ occluding the $\delta-\mathrm{MnO}_{2}$ and completely preventing oxidation when the $C_{r}$ (III) was added. This suggests a way to treat and dispose of metal finishing wastes. By adding $\mathrm{FeCl}_{3}$ to the acidic waste and then raising the $\mathrm{pH}$ the metals precipitate and are trapped in the amorphous $\mathrm{Fe}(\mathrm{OH})_{3}$. Since $\mathrm{Fe}(\mathrm{OH})_{3}$ is stable in well-oxidized soils, the $\mathrm{Fe}(\mathrm{OH})_{3}$ sludge with the entrained metals can be added to a well-drained soil. 


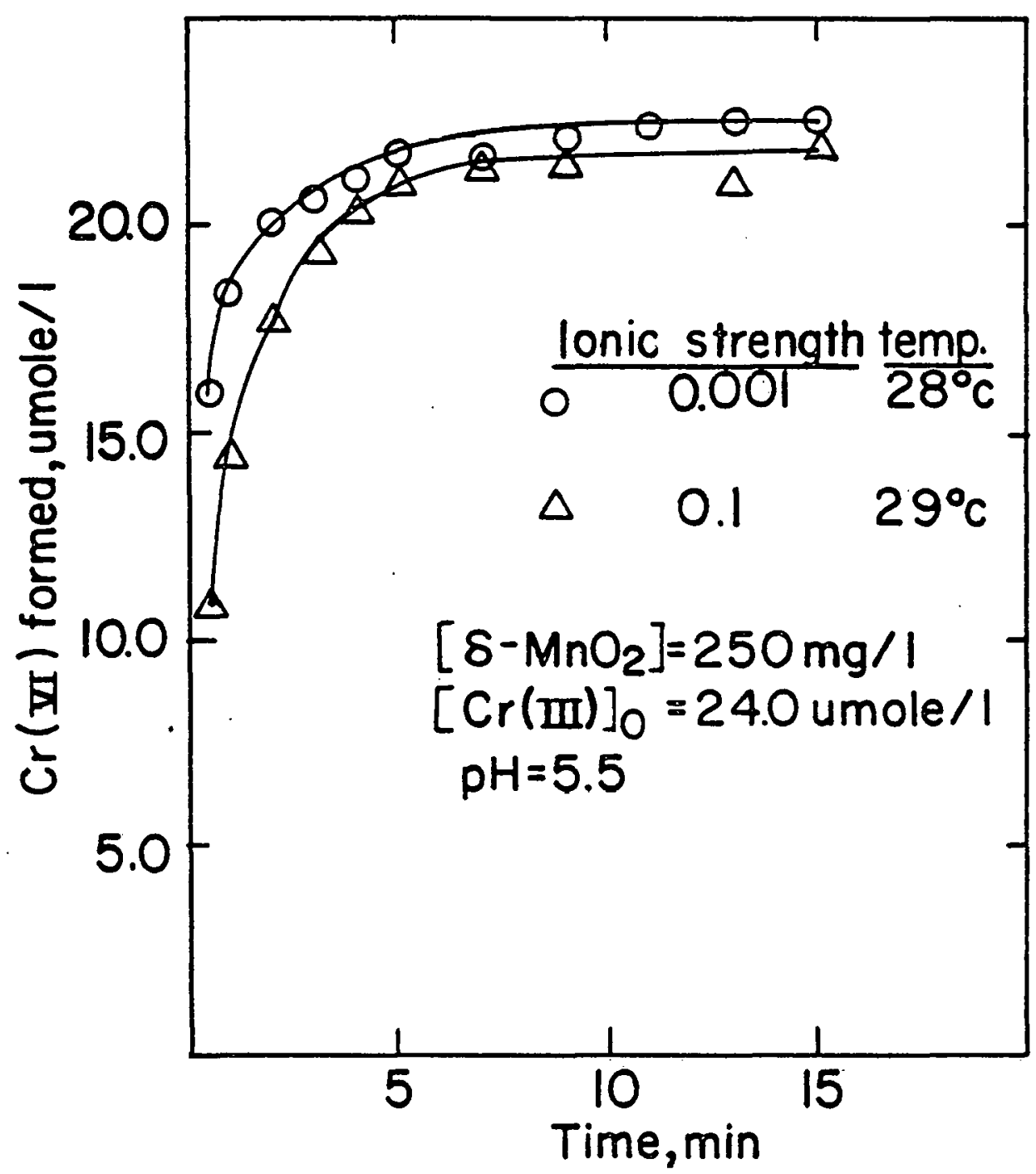

Figure 24. Effect of ionic strength on the kinetics of $\mathrm{Cr}$ oxidation by $\delta-\mathrm{MnO}_{2}$. 


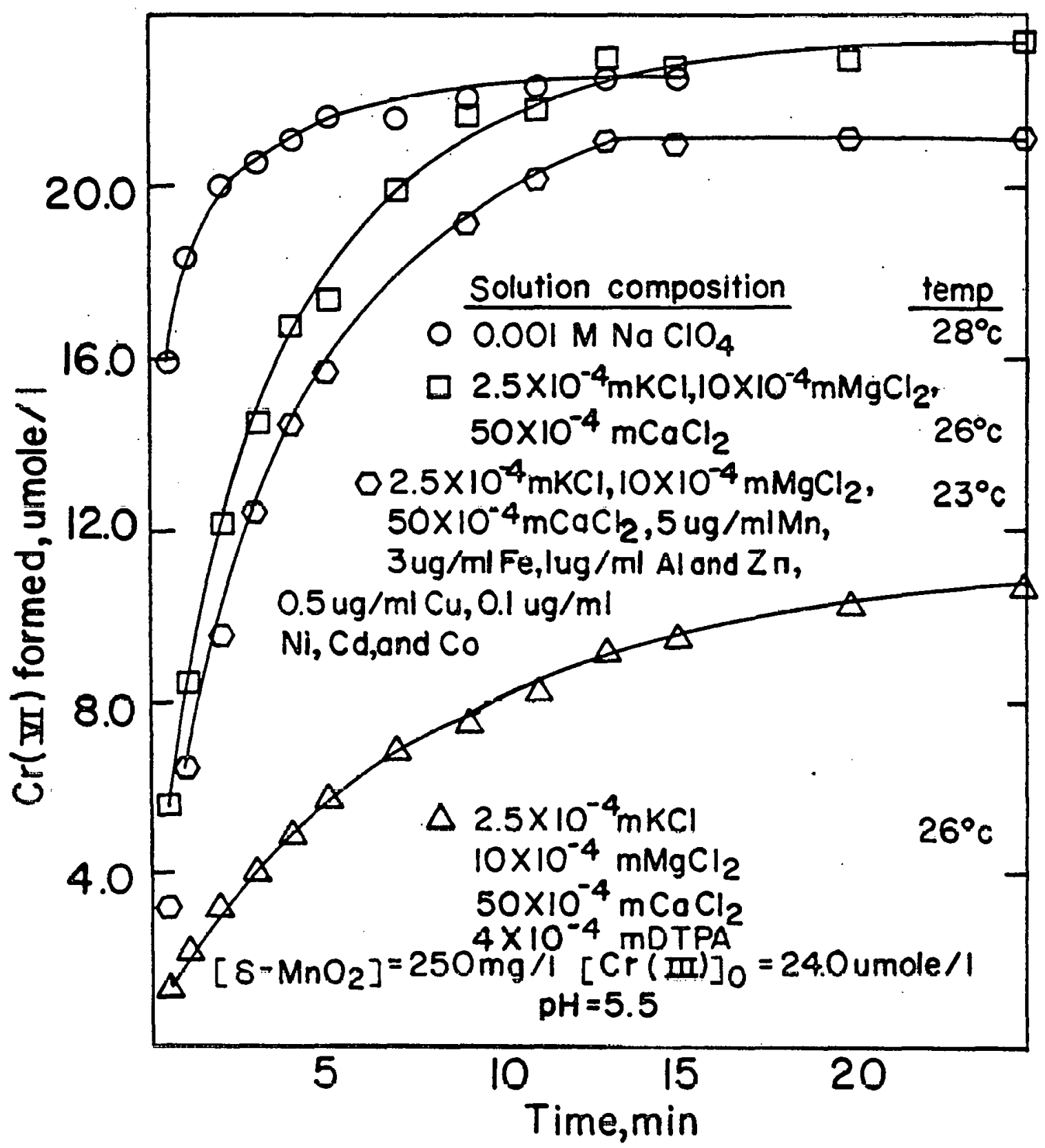

Figure 25. Effect of solution composition on the kinetics of $\mathrm{Cr}$ oxidation by $\delta-\mathrm{MnO}_{2}$. 
As long as oxidizing conditions prevail the $\mathrm{Fe}(\mathrm{OH})_{3}$ will remain stable in the soil.

Earlier it was suggested that all of the solution $\operatorname{Cr}$ (III) was not oxidized in any of the experiments because the $M($ IV) at the mineral surface was "used up". The effect of surface area available for oxidizing $\mathrm{Cr}$ on the rate of $\mathrm{Cr}$ oxidation by $\delta-\mathrm{MnO}_{2}$ can be seen in Figure 26. The surface area of $\delta-\mathrm{MnO}_{2}$ available for oxidizing $\mathrm{Cr}$ was varied by using different amounts of $\delta-\mathrm{MnO}_{2}$ while holding the initial $\mathrm{Cr}$ (III) concentration constant. In this experiment the $\delta-\mathrm{MnO}_{2}$ was hydrosonically dispersed to achieve the maximum possible surface area. In previous experiments dispersion was by rapidly mixing in solution so the maximum surface area was not achieved. The graph clearly shows that there was an initial rapid production of $\operatorname{Cr}(V I)$ which then quickly fell off. This fall-off occurred within a few minutes. In each case there was more than enough $\delta-\mathrm{MnO}_{2}$ to oxidize all of the added $\mathrm{Cr}$ (III), but the amount actually oxidized fell short of the total possible. The amount oxidized decreased with the amount of $\delta-\mathrm{MnO}_{2}$ used.

It would now seem that the only way to oxidize more $\mathrm{Cr}$ would be to use an excess amount of $\operatorname{Cr}$ (III), and thus begin dissolving the mineral. Such an occurrence can be seen by examining Figure 27 where the oxidation of $\operatorname{Cr}($ III) and reduction of $M($ IV) was followed upon dissolving $\delta-\mathrm{MnO}_{2}$ in excess $\mathrm{CrCl}_{3}$ solution. A plateau was reached on the $\mathrm{Cr}$ oxidation curve after a few minutes which corresponded to using up the surface $\mathrm{Mn}(\mathrm{IV})$. The reaction would have stopped here if $\delta-\mathrm{MnO}_{2}$ was in excess of $\mathrm{Cr}$, but with excess $\mathrm{Cr}$ present the reaction rate began accelerating again and did not slow. until most of the mineral was dissolved. The Mn reduction rate also started off slowly and then quickly accelerated 


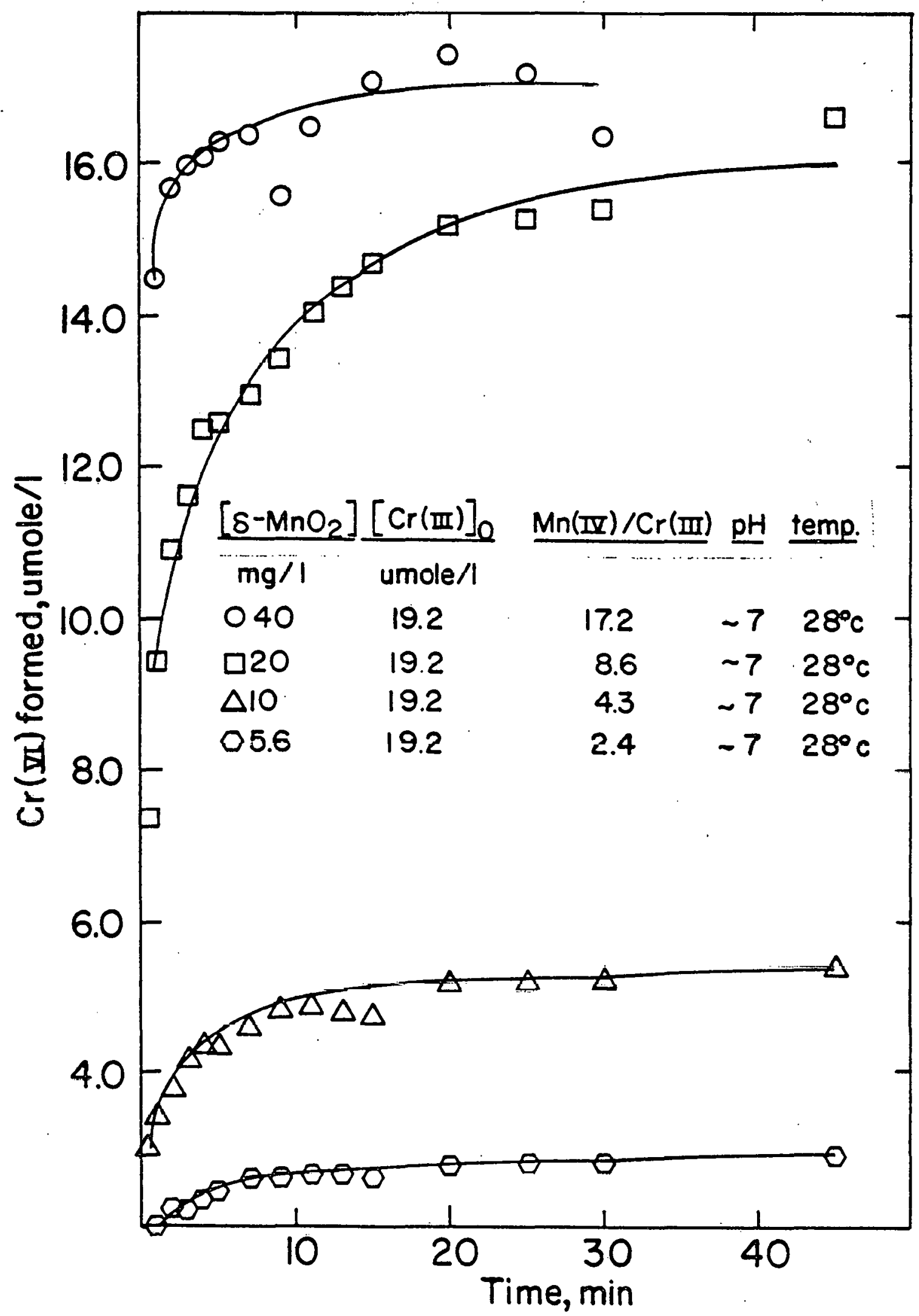

Figure 26. Effect of varying amounts of $\delta-\mathrm{MnO}_{2}$ on the kinetics of $\mathrm{Cr}$ oxidation by $\delta-\mathrm{MnO}_{2}$. 


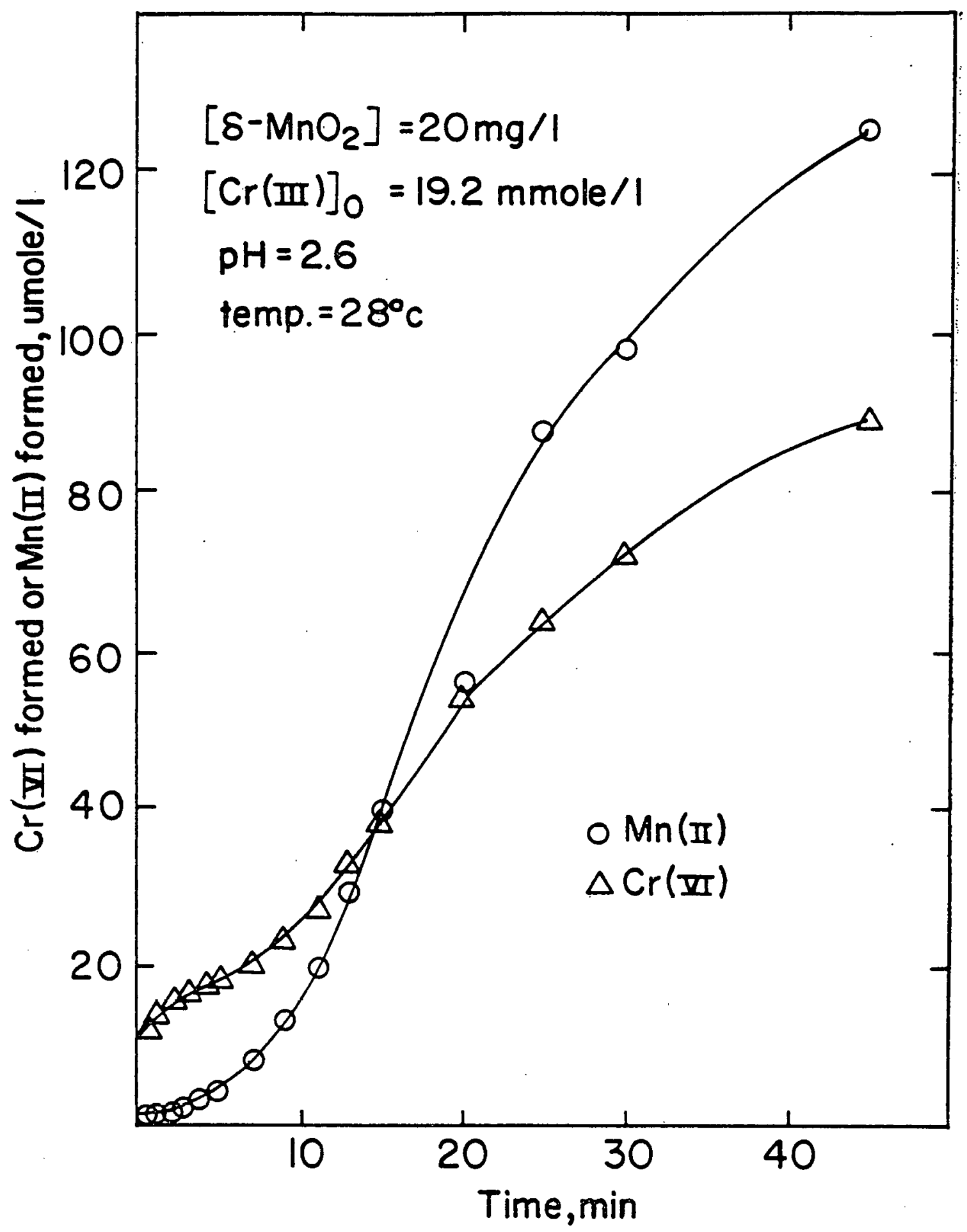

Figure 27. Kinetics of $\mathrm{Cr}$ oxidation by $\delta-\mathrm{MnO}_{2}$ and $\mathrm{Mn}$ reduction by $\mathrm{Cr}$ (III) with excess $\mathrm{Cr}$ present. 
as the mineral was dissolved. The normal environmental situation in the case of soils would probably be excess $\delta-\mathrm{MnO}_{2}$ over $\mathrm{Cr}$ except in localized regions. Excess $\mathrm{Cr}$ over $\delta-\mathrm{MnO}_{2}$ might occur when highly $\mathrm{Cr}$-contaminated wastewater is discharged into a natural body of water.

The reduction of $\delta-\mathrm{MnO}_{2}$ by excess $\mathrm{Cr}$ as affected by temperature at low ph is shown in Figure 28. The initial reaction rate at this $\mathrm{pH}$ was obviously following zero-order kinetics. This is not surprising, since Cr was in excess and the reaction could proceed on $1 y$ as fast as the available surface area would allow. The low $\mathrm{pH}$ assured that as the Mn(IT) was prnduced it wae rolcoocd to solution, thus lhe S-shaped curve of Figure 27 was avoided. The rate coefficients were $0.46 \mu \mathrm{mole} / \ell / \mathrm{min}$ at $25^{\circ} \mathrm{C}$ and $6.26 \mathrm{\mu mole} / \ell / \mathrm{min}$ at $48^{\circ} \mathrm{C}$. The activation energy was 21.5 kcal per mole.

The mineral $\delta-\mathrm{MnO}_{2}$ is not the only $\mathrm{MnO}_{2}$ mineral capable of oxidizing Cr as the results in Figure 29, demonstrate. At. a Mn, concentration of $250 \mathrm{mg} / \mathrm{l}$ and without hydrosonic dispersion both $\delta-\mathrm{MnO}_{2}$ and $\mathrm{Mn}$ (II)manganite oxidized $\mathrm{Cr}$ rather rapidly with $\mathrm{Mn}(\mathrm{II})$-manganite producing complete oxidation of the added $\operatorname{Cr}($ III). However, at $20 \mathrm{mg} / \ell$ and with hydrosonic dispersion the larger surface area of $\delta-\mathrm{MnO}_{2}$ revealcd itself in that it oxidized $\mathrm{Cr}$ faster than did the Mn(II)-manganite. The mineral $\alpha-\mathrm{MnO}_{2}$ oxidized $\mathrm{Cr}$ much more slowly than did $\delta-\mathrm{MnO}_{2}$ or $\mathrm{Mn}(\mathrm{II})-$ manganite. 'The $\alpha$ form of $\mathrm{MnO}_{2}$ exhibits ion-exchange properties and the rate of oxidation could be slowed even further by adding competing cations to the suspension to block the access of $C_{r}$ to the sites where oxidation occurred. The oxidation of $\mathrm{Cr}$ by $\mathrm{B}-\mathrm{MnO}_{2}$ (pyrolusite) was so slow that it could not even be shown on the figure. Experiments were run at different $\mathrm{pH}$ levels and amounts of $\mathrm{Cr}$ and $\mathrm{B}-\mathrm{MnO}_{2}$, but no 


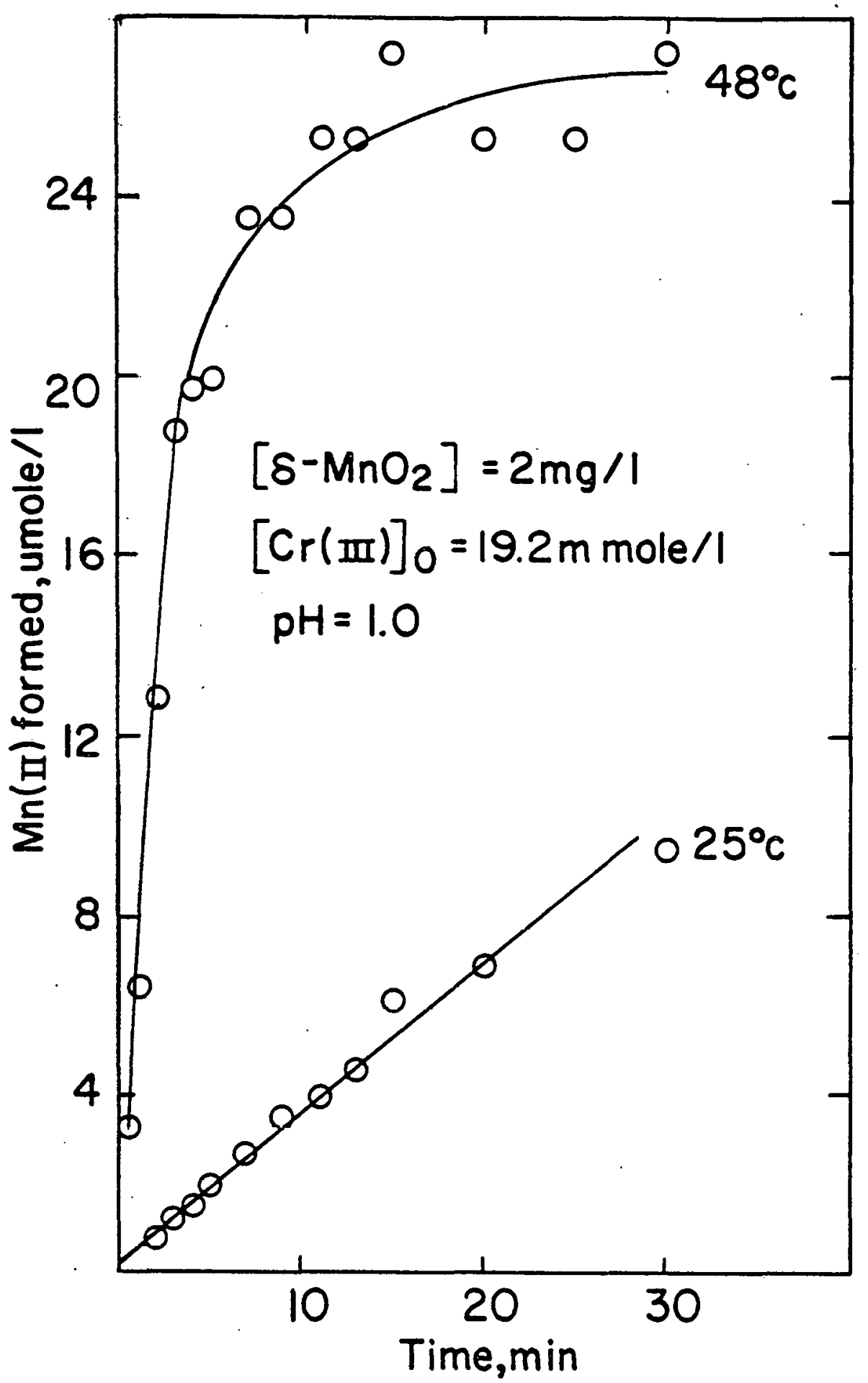

Figure 28. Effect of temperature on the kinetics of Mn reduction by $\mathrm{Cr}$ (III) at $\mathrm{pH} 1.0$ with excess $\mathrm{Cr}$ present. 


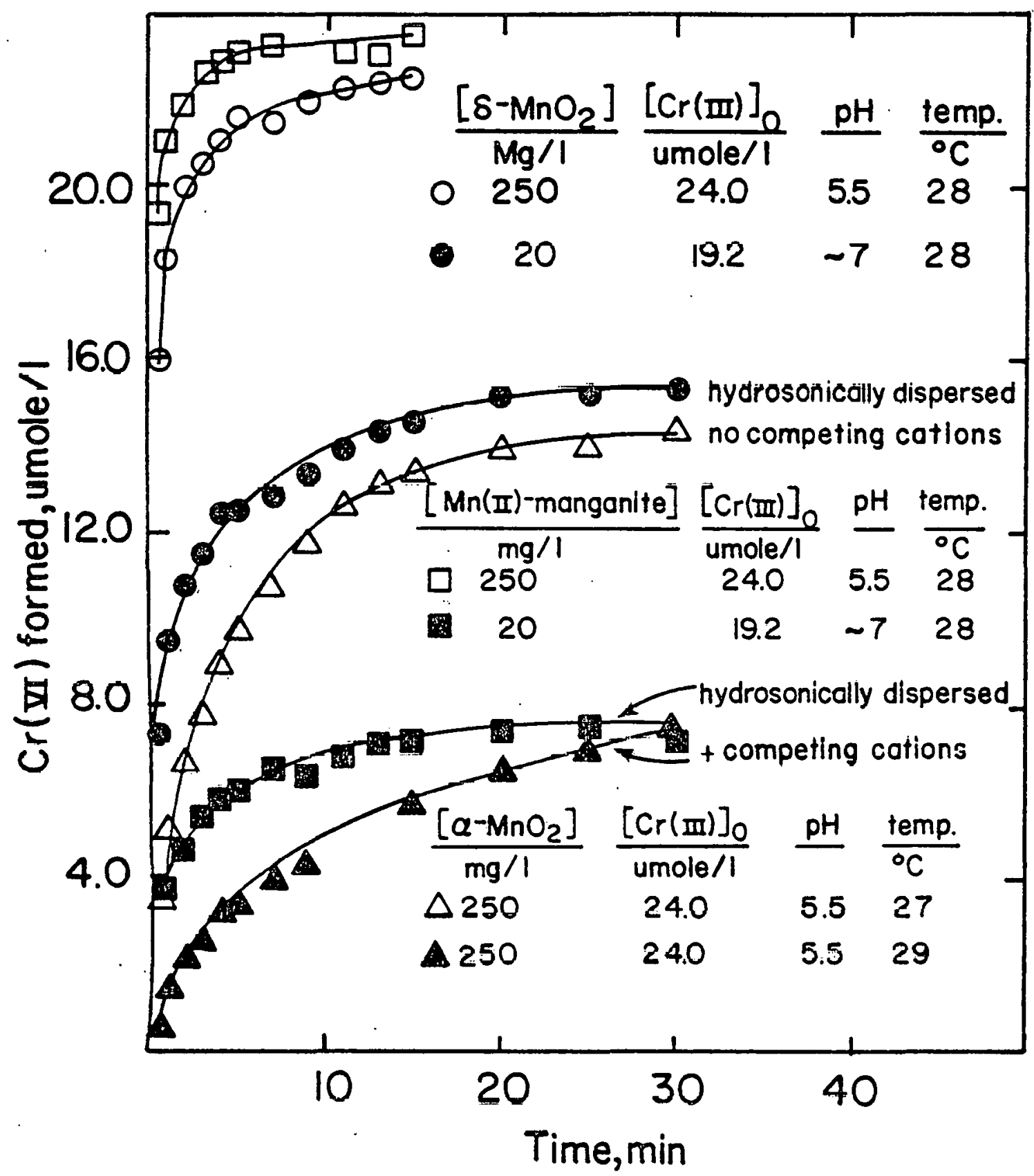

Figure 29. Kinetics of $\mathrm{Cr}$ oxidation by various $\mathrm{MnO}_{2}$ minerals under selected conditions. 
significant amount of oxidation by $\beta-\mathrm{MnO}_{2}$ was ever observed even after many days. Pyrolusite is the most stable form of $\mathrm{MnO}_{2}$ and the most crystalline form. However, its occurrence in soils is apparently limited (McKenzie, 1977).

Many of the experiments made use of an autotitrimeter to return the $\mathrm{pH}$ to a preset level after the $\mathrm{Cr}$ (III) solution was added. The suspensions were acidified upon adding $\operatorname{Cr}$ (III) because of hydrolysis. The amount of base needed to return the $\mathrm{pH}$ to the preset level over the course of the experiment is known as $\mathrm{OH}^{-}$demand and examples of $\mathrm{OH}^{-}$demand curves are presented in Figures 30 and 31 . In Figure 30 the effect of temperature on $\mathrm{OH}^{-}$demand during $\mathrm{Cr}$ oxidation in moist Hagerstown silt loam is shown. As the diagram shows temperature had a large effect on $\mathrm{OH}^{-}$ demand which was not yet satisfied even after one hour. Because the added $\mathrm{Cr}$ was trivalent, one would expect three protons to need neutralized for every $\mathrm{Cr}$ (III) ion added. Thus, when fully satisfied the $\mathrm{OH}^{-} / \mathrm{Cr}^{3+}$ ratio should be 3 to 1 . However, after one hour the $\mathrm{OH}^{-}$ demand was not yet satisfied and the $\mathrm{OH}^{-} / \mathrm{Cr}^{3+}$ ratio was 2 to 1 . These observations were due to reactions of $\mathrm{H}^{+}, \mathrm{OH}^{-}$, and $\mathrm{Cr}^{3+}$ ions with soil other than simple neutralization reactions. This depressed the $\mathrm{OH}^{-}$ demand. However, the effect of temperature on $\mathrm{OH}^{-}$demand during $\mathrm{Cr}$ oxidation by $\delta-\mathrm{MnO}_{2}$ was slight compared to the temperature effect when soil was used. The $\mathrm{OH}^{-}$demand was mostly satisfied in $15 \mathrm{~min}$ with the $\mathrm{OH}^{-} / \mathrm{Cr}^{3+}$ ratio approaching the 3 to 1 value predicted. Apparently, the OH" ions added only had to neutralize the protons from $\operatorname{Cr}$ (III) hydrolysis and did not have time to react with the $\delta-\mathrm{MnO}_{2}$. 


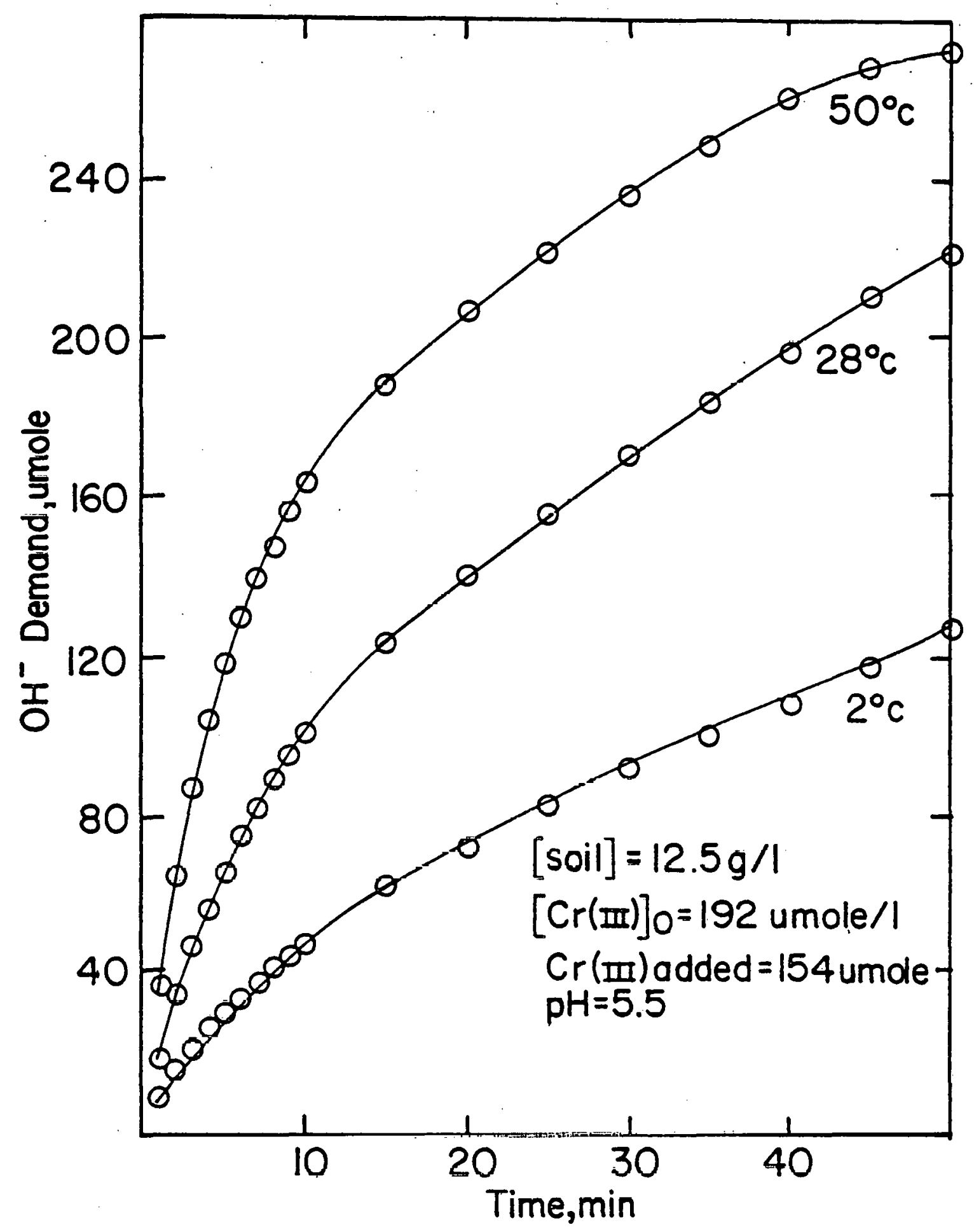

Figure 30. Effect of temperature on $\mathrm{OH}^{-}$demand during $\mathrm{Cr}$ oxidation and sorption in moist Hagerstown silt loam. 


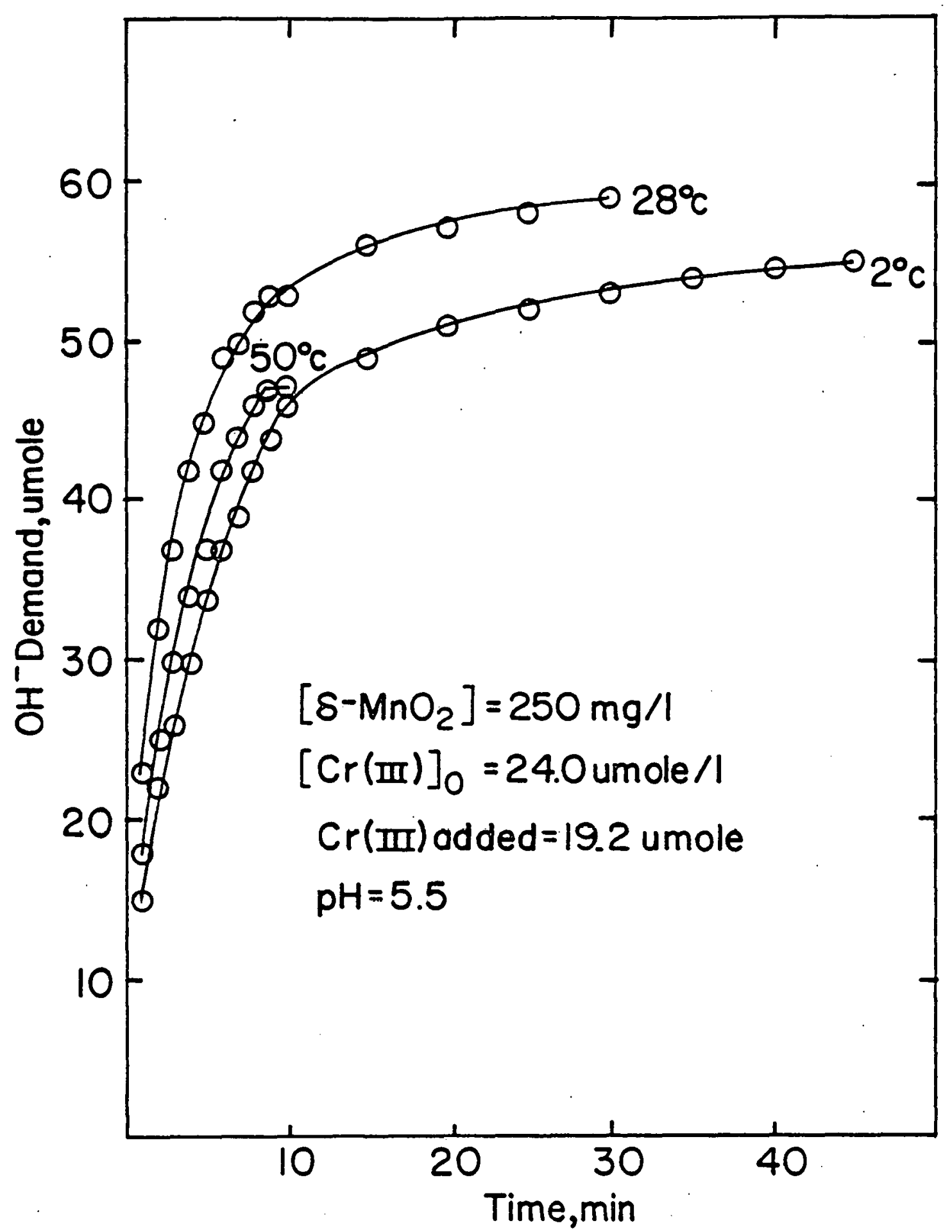

Figure 31. Effect of temperature on $\mathrm{OH}^{-}$demand during $\mathrm{Cr}$ oxidation by $\hat{S}-\mathrm{MnO}_{2}$. 
Kinetics of $\mathrm{Cr}$ Oxidation by $\delta-\mathrm{MnO}$ in the Presence

of Fulvic Acid and the Kinetics of $\mathrm{Cr}$ and $\mathrm{Mn}$

Reduction by Fulvic Acid

A number of times it has been suggested that the rate of $\mathrm{Cr}$ reduction in soil is slow. A number of experiments were designed to study the rate of $\mathrm{Cr}$ reduction in soil and by soluble organic matter to determine the reaction rates. In the first experiment the rate of $\mathrm{Cr}$ reduction in moist Hagerstown silt loam was studied and the results are presented in Figure 32. Unlike the complicated case of $\mathrm{Cr}$ oxidation, $\mathrm{Cr}$ reduction kinetics are straightforward. Reduction follows first order kinetics. Under the conditions shown in Figure 32 the rate coefficient for reduction was $0.012 \mathrm{day}^{-1}$ and the half-life was about 55 days. In contrast with this, a half-life of 17 days was calculated from the results of the incubation experiment (Table 28). However, in the incubation experiment more soil was used than in the kinetic experiment, so there was a greater opportunity for the incubation experiment to become more reducing due to more organic matter being present. Also, the $\mathrm{Mn}$ (IV)/Cr(III) ratio was greater in the incubation experiment than in the kinetic experiment. In both the kinetic and incubation experiments only the loss of solution $\operatorname{Cr}(V I)$ was measured. However, the Hagerstown silt loam does sorb some $\operatorname{Cr}(V I)$, so in order to study $\mathrm{Cr}$ reduction in the absence of side reactions, $C r$ reduction by fulvic acid, the soluble portion of soil organic matter, was studied.

In the first experiment the kinetics of $\mathrm{Cr}$ reduction by fulvic acid extracted from Murrill silt loam were studied under varying $\mathrm{pH}$ and temperature conditions and the results are diagrammed in Figure 33 . It is clear that reduction by fulvic acid is slow at environmentally 


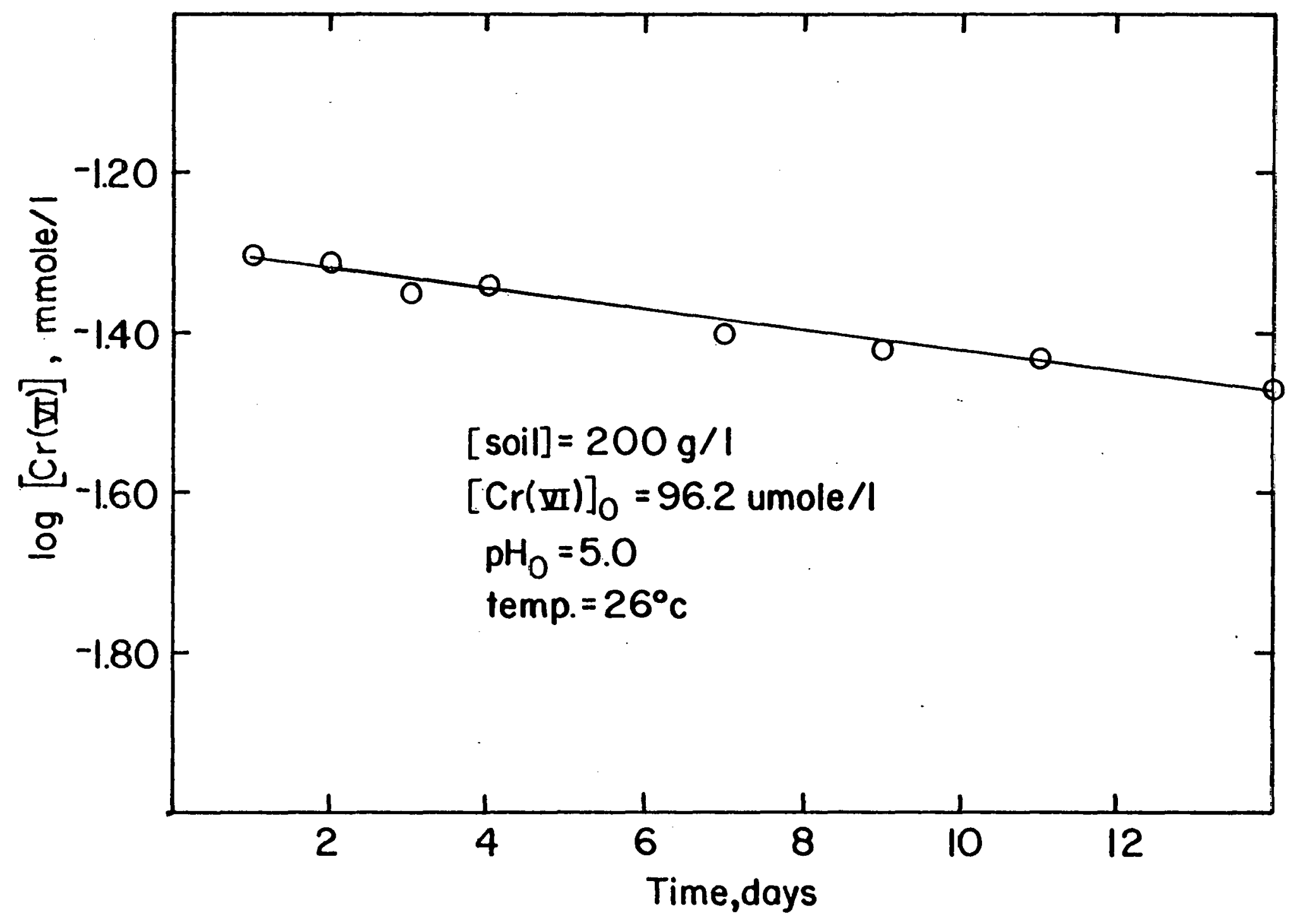

Figure 32. Kinetics of Cr reduction in molst Hagerstown silt loam. 


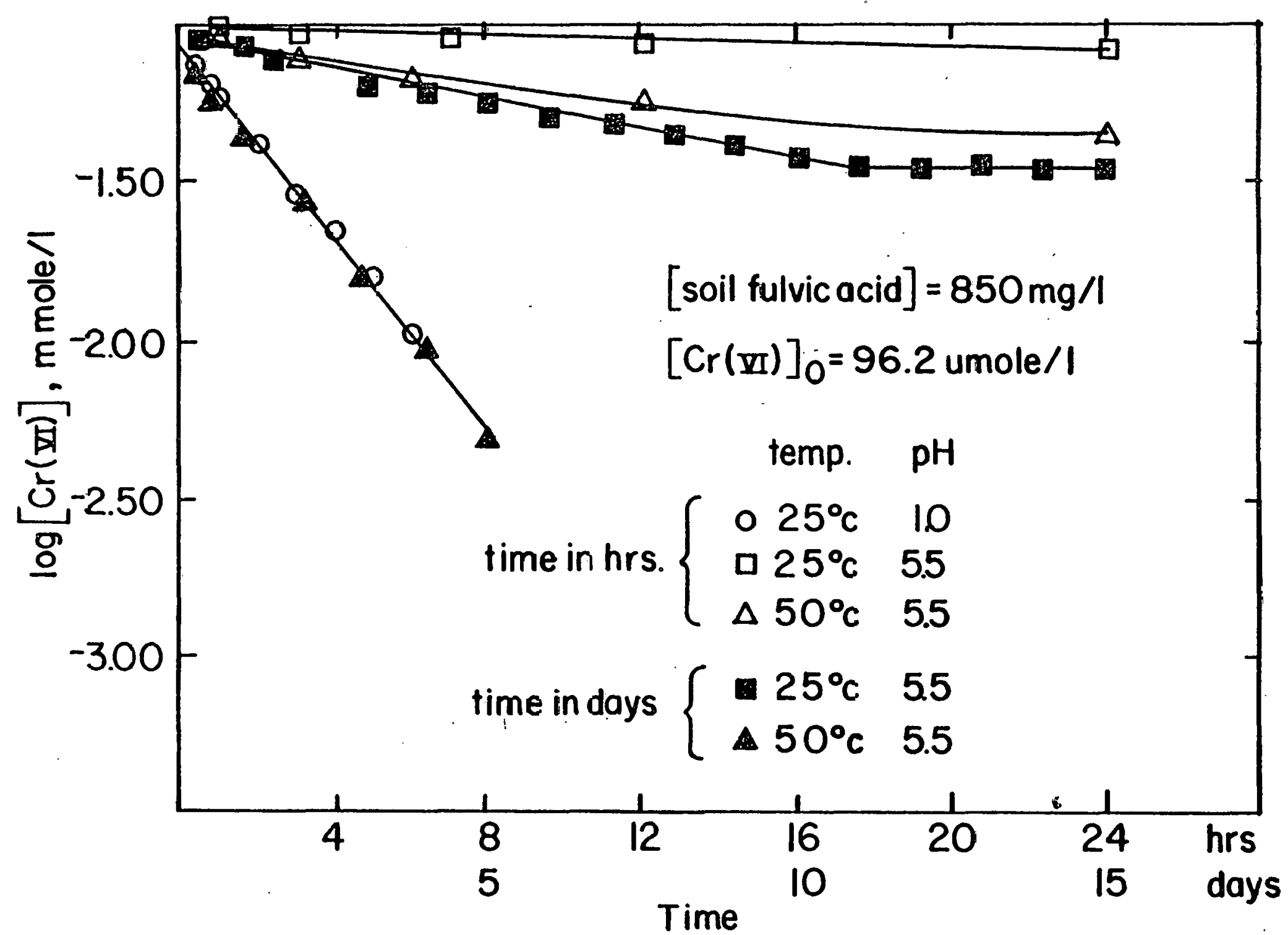

Figure 33. Effects of texperature ane FH on the kinetics of $\mathrm{Cr}$ ræduction by soll fulvic acid. 
important $\mathrm{pH}$ and temperature levels. The rate of reduction could be increased by increasing the temperature, but the most dramatic rate increase was produced by lowering the $\mathrm{pH}$ of the solution. This large rate increase occurred because protons are one of the reactants in the reduction reaction (Bartlett and Kimble, 1976b):

$$
\mathrm{HOHC}=\mathrm{R}=\mathrm{CHOH}+\mathrm{K}_{2} \mathrm{Cr}_{2} \mathrm{O}_{7}+6 \mathrm{HCl}=\mathrm{KOOC}-\mathrm{R}-\mathrm{COOK}+2 \mathrm{CrCl}_{3}+5 \mathrm{H}_{2} \mathrm{O}
$$

The increase in the rate of $C r$ reduction by fulvic acid upon acidification of fulvic acid agrees qualitatively with the increase in the rate of Cr reduction by manure that Bartlett and Kimble (1976b) observed upon acidifying the manure. Observed rate coefficients for $\mathrm{Cr}$ reduction by soil fulvic acid were $0.15 \mathrm{hr}^{-1}$ at $25^{\circ} \mathrm{C}$ and $\mathrm{pH} 1,0.037 \mathrm{day}^{-1}$ at $25^{\circ} \mathrm{C}$ and $\mathrm{pH} 5.5$, and $0.23 \mathrm{day}^{-1}$ at $50^{\circ} \mathrm{C}$ and $\mathrm{pH} \mathrm{5.5}$. The half-lives were 4.6 hrs at $25^{\circ} \mathrm{C}$ and $\mathrm{pH} 1,19$ days at $25^{\circ} \mathrm{C}$ and $\mathrm{pH} \mathrm{5.5}$, and 3 days at $50^{\circ} \mathrm{C}$ and $\mathrm{pH}$ 5.5. The 19-day half-life at $25^{\circ} \mathrm{C}$ and $\mathrm{pH} 5.5$ agrees very well with the 17-day half-life from the incubation experiment run at $25^{\circ} \mathrm{C}$ and $\mathrm{pH}$ 5.1. The activation energy for reduction was $13.9 \mathrm{kcal} / \mathrm{mole}$.

The kinetics of $\mathrm{Cr}$ reduction by leather dust fulvic acid was also studied and these results are graphed in Figure 34 . It is obvious that leather dust fulvic acid reduced $C r$ faster than soil fulvic acid. Since both soil and leather dust fulvic acids were in excess of that needed to reduce all of the initial $\operatorname{Cr}(V I)$ added, the faster rate with the leather dust fulvic acid was probably due to the greater catalytic activity of the microorganisms in the leather dust. Filamentous. microorganism growths were observed in the leather dust fulvic acid solutions. The slope changes in the diagram were due to $\mathrm{pH}$ changes. The solutions were initially adjusted to $\mathrm{pH} 5.5$, but the microorganisms kept buffering the $\mathrm{pH}$ up toward 7 as time went on as periodic $\mathrm{pH}$ measurements demonstrated. 


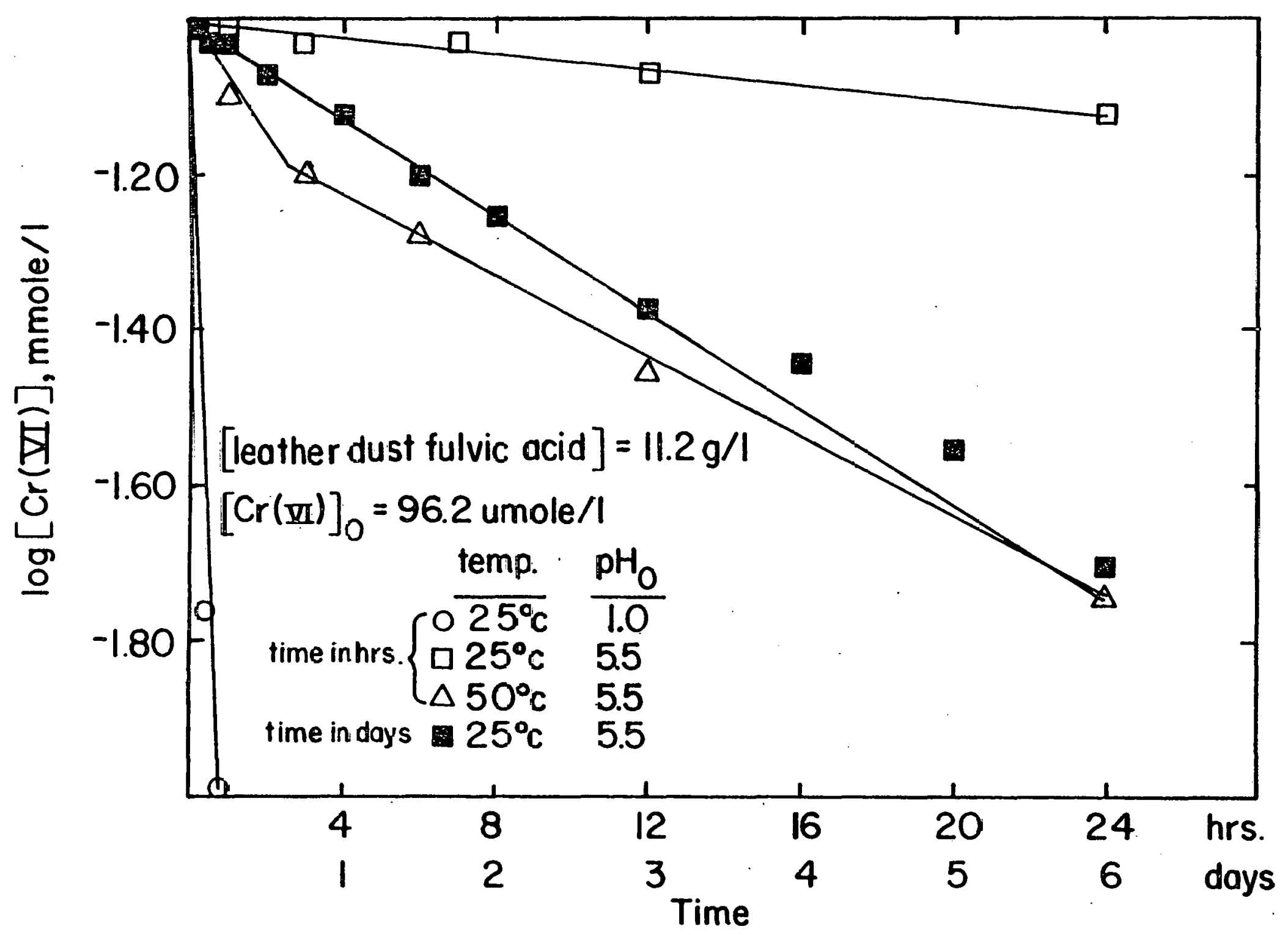

Figure 34. Effects of temperature and $\mathrm{pH}$ on the kinetics of $\mathrm{Cr}$ reduction by leather dust fulvic acid. 
Rate coefficients were not calculated for these curves because of the uncertainties in the data due to the microorganism activities.

The experiments on $\mathrm{Cr}$ reduction by fulvic acid demonstrated the slow rate of the reaction. The question now remains as to whether fulvic acid can actually prevent the oxidation of $\mathrm{Cr}$ by $\delta-\mathrm{MnO}_{2}$. This question is answered by Figures 35 and 36 . A fulvic acid extract of leather dust after removing the humic acid and $B$-humus impurities was found to contain $70 \mu \mathrm{g} / \mathrm{ml}$ of $\mathrm{Cr}$. When mixed with $\delta-\mathrm{MnO}_{2}$ no oxidation of the $\mathrm{Cr}$ in the leather dust fulvic acid was observed. Apparently the fulvic acid-Cr complex is stable toward oxidation. However, when a soluble $\mathrm{CrCl}_{3}$ solution was added oxidation did occur as shown in Figure 35. The characteristic rapid initial increase in $\operatorname{Cr}(\mathrm{VI})$ was observed followed by the rapid fall-off in oxidation rate. Obviously, the fulvic acid was unable to prevent this oxidation. Oxidation is only prevented if a stable organo-Cr complex is formed before the $\mathrm{Cr}$ has a chance to contact the $\delta-\mathrm{MnO}_{2}$. The maximum amount of $\mathrm{Cr}$ (VI) was reached after several hours, but this amount was much less than the amount that would have been reached if the fulvic acid was not present, so the fulvic acid was able to prevent some of the $\operatorname{Cr}$ (III) from being oxidized. Eventually the rate of reduction of the $\operatorname{Cr}(V I)$ dominated. All of the $\mathrm{Cr}$ reduction experiments showed that substantial amounts of $\mathrm{Cr}$ (VI) could persist for long periods of time in soil, probably long enough to be leached out and contaminate ground water.

Besides the oxidation of $\mathrm{Cr}$ (III) by $\delta-\mathrm{MnO}_{2}$ and the reduction of $\mathrm{Cr}$ (VI) by organic matter, the reduction of $\delta-\mathrm{MnO}_{2}$ by organic matter should be considered. In Figure 37 are shown the kinetics of $\delta-\mathrm{MnO}_{2}$ reduction by leather dust fulvic acid. Although reduction was slow it 


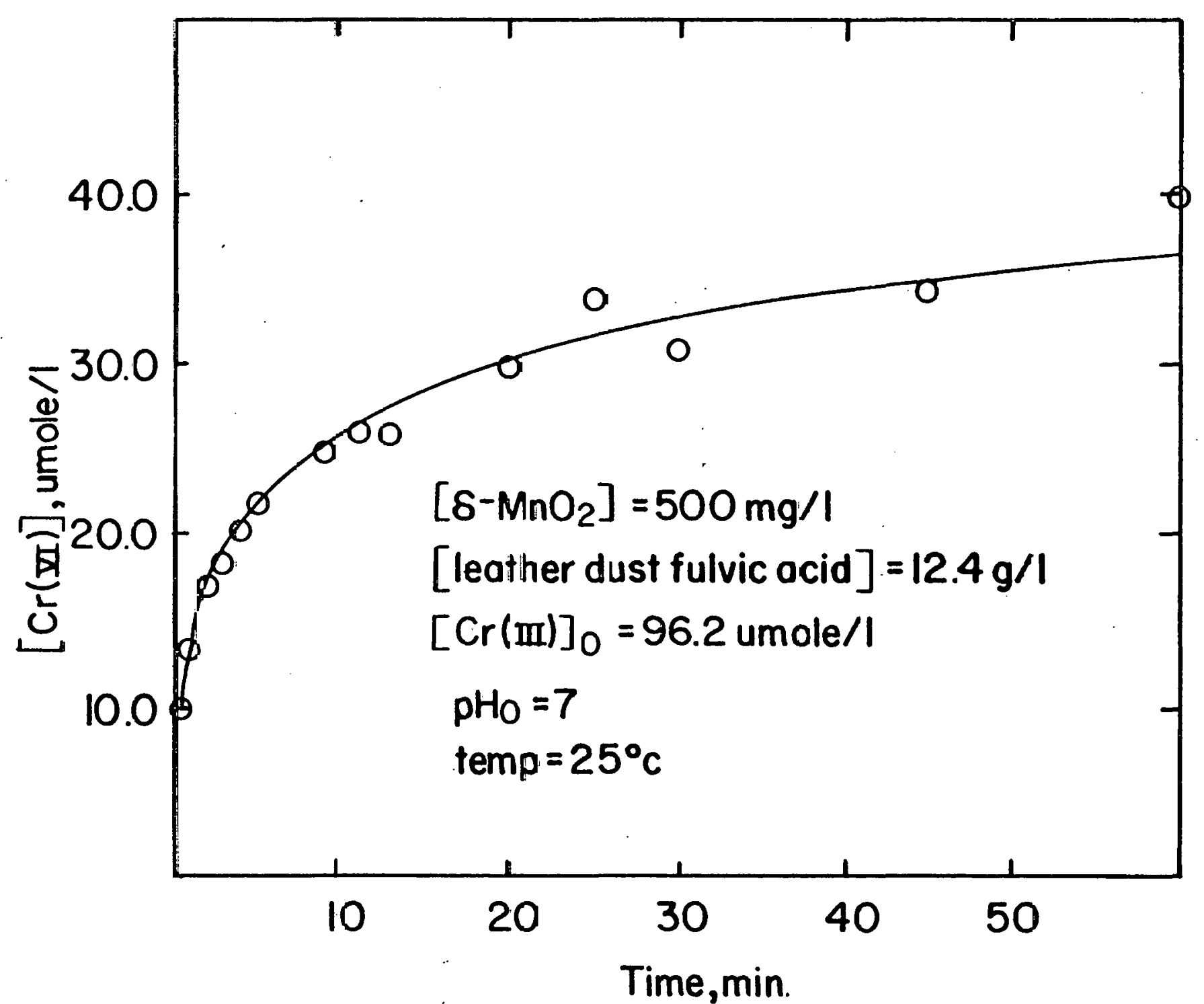

Figure 35. Kinetics of $\mathrm{Cr}$ axidation by $\delta-\mathrm{MnO}_{2}$ in the presence of leather dust fulvic acid over a short time period. 


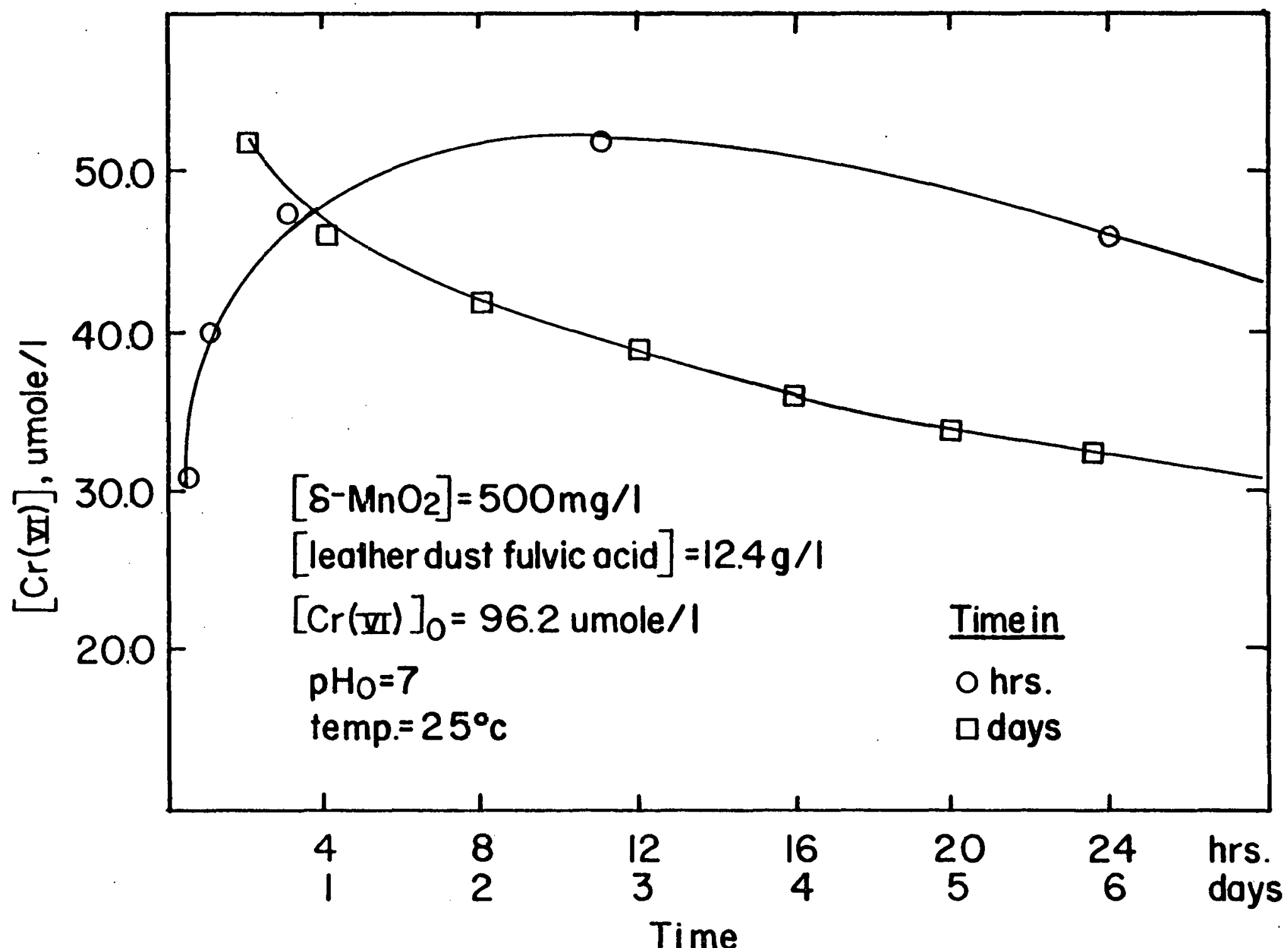

Figure 36. Kinetics of $\mathrm{Cr}$ oxidation by $\delta-\mathrm{MnO}_{2}$ in the presence of leather dust fulvic acid over a long time period. 


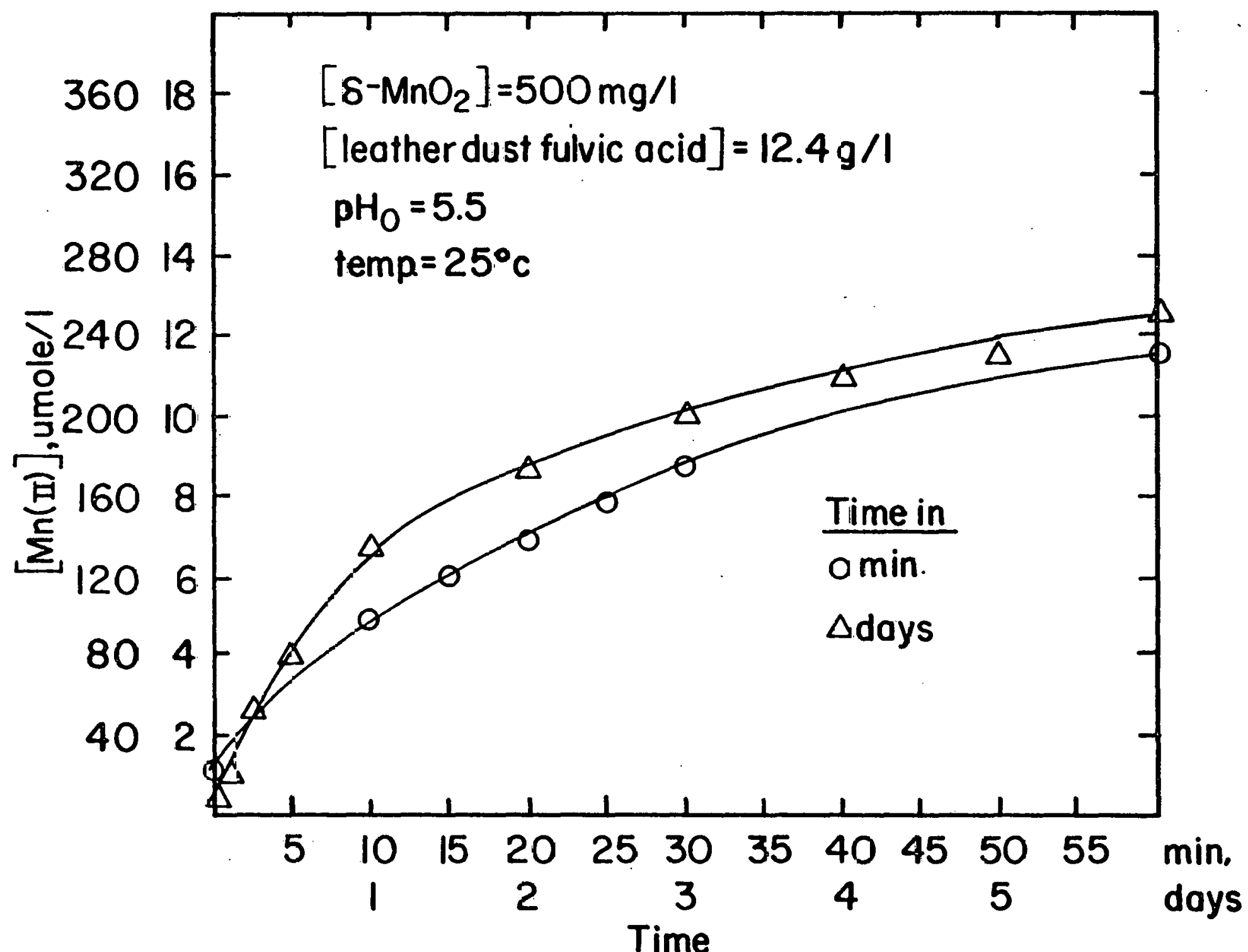

Figure 3i. Kinetics of Mn raduction by leather dust fulvie acid. 
is apparent that if the soluble organic matter concentration is high enough, $\mathrm{MnO}_{2}$ coatings in the soil can be destroyed thereby eliminating the danger of $\mathrm{Cr}$ oxidation. High soluble organic matter concentrations are expected in reduced soils high in organic matter content. 
SUMMARY AND CONCLUSIONS

As a result of atmospheric testing of nuclear devices at the Nevada Test Site in southern Nevada, the soil and vegetation of several areas on the test site are contaminated with transuranic elements, particularly $\mathrm{Pu}$ and Am. Although particulate movement through erosion by the forces of wind and water is the most important mechanism of dispersing $\mathrm{Pu}$ at the test site, there is some evidence of Pu migration through some soil profiles perhaps due to dispersion of water soluble species. Under the direction of the Nevada Applied Ecolngy Group of the U.S. Department of Energy, a program is being developed to monitor the dispersion and bioavailability of transuranics, especially $\mathrm{Pu}$, in the environment.

However, because $\mathrm{Pu}$ is toxic, usually insoluble, not uniformly distributed in the soil, and can exist in four oxidation states in the environment, it is a difficult element to study. Therefore, $C r$ reactions in soil were investigated as a possible general model for Pu reactions in soil, since it was postulated that the redox chemistries of the two elements should be similar. An evaluation of data from the literature Indicated that the reduced forms of both elements are usually relatively immobile in soils while the oxidized forms are usually relatively mobile and hence more bioavailable. The redox chemistries of both elements appear to be controlled by organic watter, minerals containing Fe(II), and manganese oxides. Thermodynamic calculations revealed that both elements should be highly soluble in the presence of manganese oxides. In addition, the solubility of $\mathrm{Pu}$ can be enhanced by radiolytic oxidation. Reduction of both elements by organic matter and oxidation of $\mathrm{Cr}$ by manganese oxides have already been demonstrated, and it was postulated 
that the conditions necessary for oxidation of $\mathrm{Pu}$ by manganese oxides exist in Nevada Test Site soils. These conditions are low organic matter levels and negligible amounts of $\mathrm{Fe}(\mathrm{II})$ in order to avoid reduction of $\mathrm{Pu}$ and high levels of $\mathrm{HCO}_{3}^{-}$and the presence of manganese oxides in order to form the $\mathrm{PuO}_{2} \mathrm{CO}_{3} \mathrm{OH}^{-}$species.

In the present study, chemical fractionation methods were used to determine the redox states of $\mathrm{Pu}$ in a Nevada Test Site soil and the amounts of $\mathrm{Pu}$ associated with various soil components in order to deduce possible reactions between the various $\mathrm{Pu}$ species and soil components so that weathering and dispersion by chemical mechanisms can be predicted. Chemical fractionation and kinetics experiments were performed to study reactions of $\mathrm{Cr}$ with soil, manganese oxides, and fulvic acids in order to provide information to eventually develop a qualitative, predictive model for $\mathrm{Pu}$ reactions in soil.

The results of the experiments in this thesis, as well as those from other Investigators, lead to the following conclusions by the author regarding the general behavior of $\mathrm{Cr}$ and $\mathrm{Pu}$ in soils as summarized by the diagrams in Figures 38 and 39.

1) Plutonium oxide is thermodynamically unstable in many soil environments as calculations revealed. However, $\mathrm{PuO}_{2}$ is resistant to weathering since all the avallable evidence indicates that weathering is slow and reagents that should dissolve $\mathrm{PuO}_{2}$ are able to extract only a small fraction of the total soil $\mathrm{Pu}$. This is especially true of NTS soils. The Pu that is extracted is probably initially sorbed to soil surfaces.

2) The $\mathrm{Pu}(\mathrm{IV})$ released by the weathering of $\mathrm{PuO}_{2}$ can undergo several possible reactions. Two of these reactions are susplion to iron 


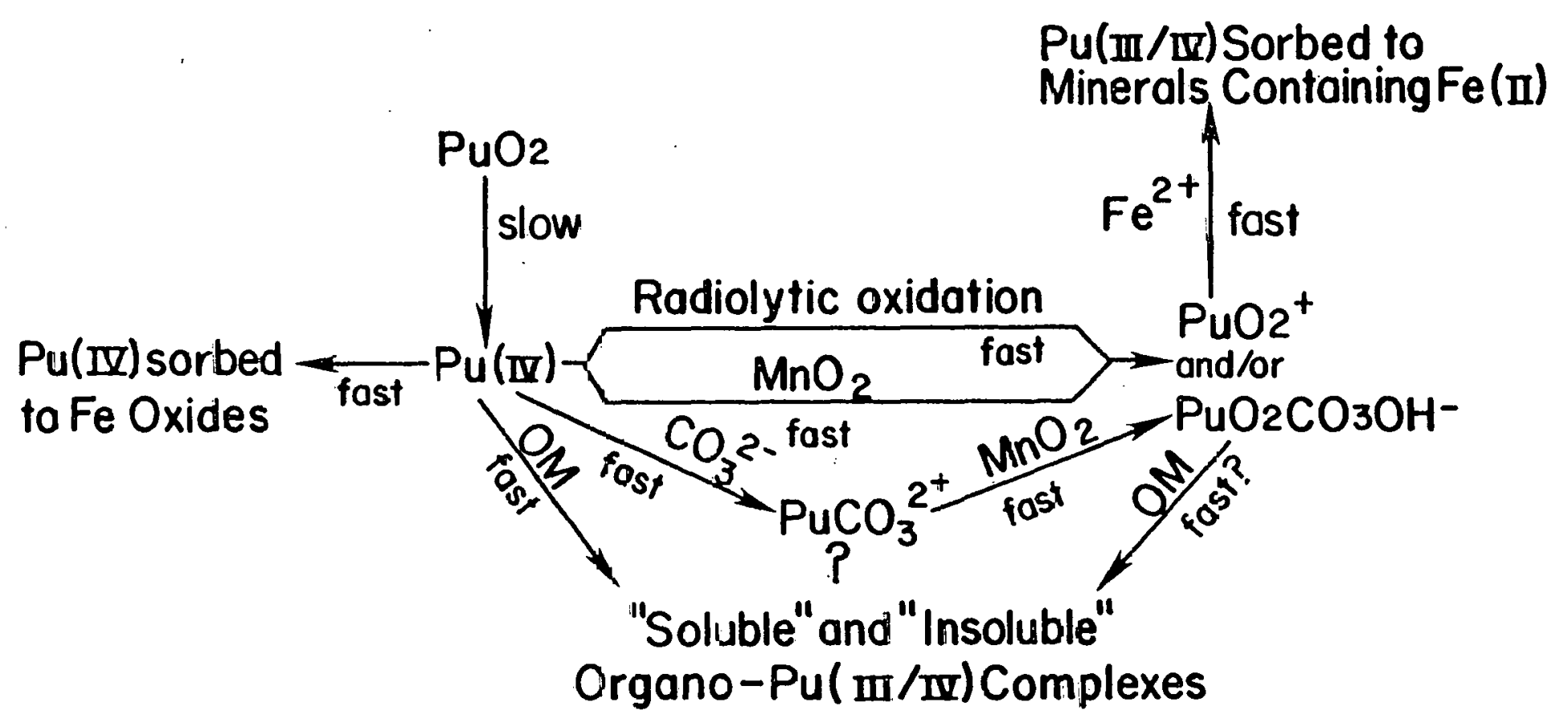

OM= Organic matter 


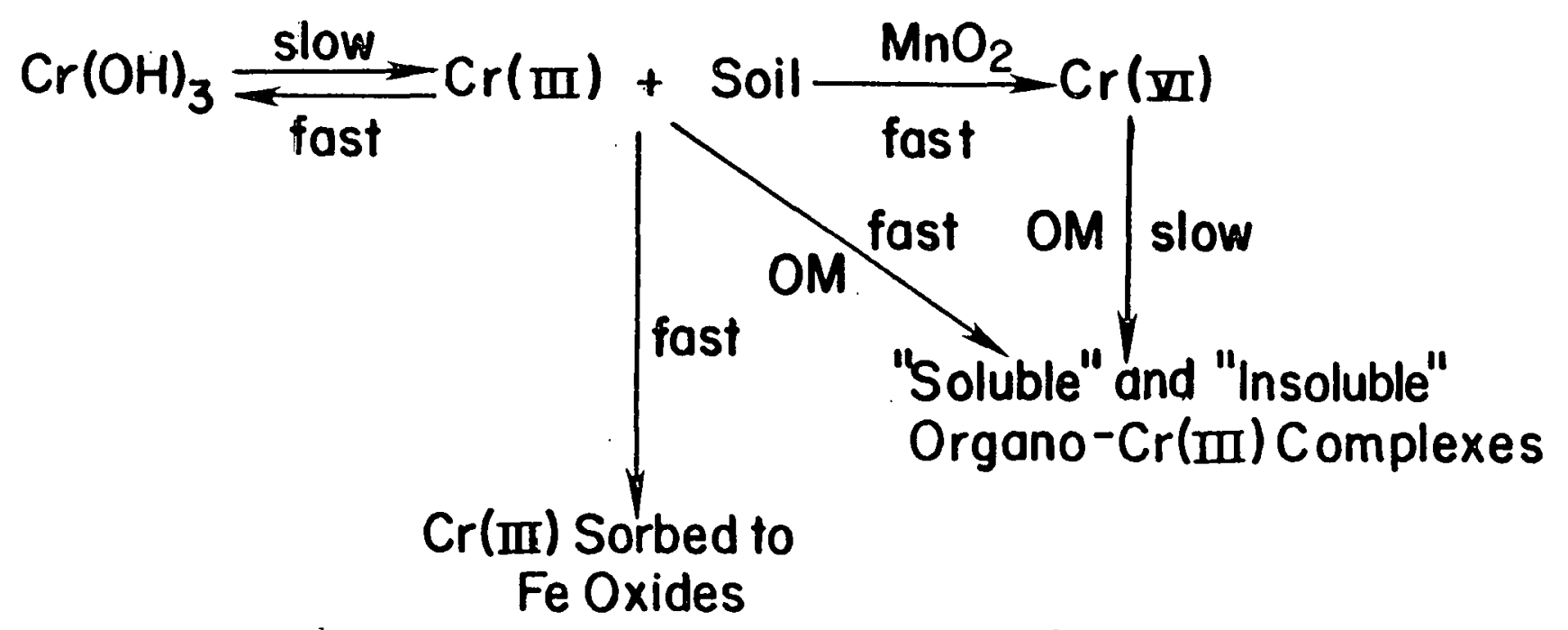

\author{
$O M=$ Organic matter
}


oxides and the formation of stable soluble and insoluble complexes with organic matter. The $\mathrm{Pu}$ remains in a reduced state in these reactions. These types of reactions are normally considered fast.

3) If the $\mathrm{PuO}_{2}$ particles are large enough, then radiolytic oxidation can occur. If the particles are submicron in size, then oxidation is probably caused by manganese oxides. Carbonate complexes can form and be oxidized. The available evidence indicates that the oxidation of solution $\mathrm{Pu}$ species is relatively fast on a geologic time scale of hundreds to thousands of years. Thus, the rate limiting step in the weathering of $\mathrm{PuO}_{2}$ must be the breakdown of the $\mathrm{PuO}_{2}$ lattice and initial formation of the soluble Pu species.

4) Once oxidiscd Pu speicles are formed they are available to migrate through the soil profile, become sorbed to soil components without reduction, or be reduced by minerals containing $\mathrm{Fe}$ (II) and/or organic matter. Reduction and sorption by minerals with Fe(II) and/or organic matter would serve to effectively immobilize the wcathered Pu. Thus, some enrichment of Pu in these soil components is to be expected.

5) The immediate bioavailability of Pu would seem to be dictated by the presence of the rolatively more mobllc oxidized Pu species which are controlled by manganese oxides and/or radiolytic effects. Mobilization of Pu by way of oxldation would serve to deliver Pu to the plant root vicinity. Reduction by root exudates and other organic matter would then undoubtedly occur. The mobility near the root would then be controlled by soluble organo-Pu complexes.

6) When soluble $\operatorname{Cr}$ (III) is added to soils several reactions are possible. If the solubility of $\mathrm{Cr}$ (III) is exceeded, $\mathrm{Cr}(\mathrm{OH})_{3}$ can be formed. 
The formation of $\mathrm{Cr}(\mathrm{OH})_{3}$ likely occurs fairly rapidly, but dissolution appears to be slow even under conditions favoring dissolution.

7) Sorption of $\operatorname{Cr}$ (III) by iron oxides and formation of soluble and insoluble complexes with organic matter also occur. The organo-Cr complexes appear especially stable to oxidation and other forms of weathering.

8) The $\operatorname{Cr}$ (III) not sorbed by iron oxides and organic matter is oxidized by soil manganese oxides. Oxidation is relatively fast, but complete oxidation is not achieved if the mineral surface available for oxidation is limited.

9) Reduction of $\operatorname{Cr}$ (VI) by organic matter will eventually dominate, but significant levels of $\mathrm{Cr}(\mathrm{VI})$ can persist for weeks.

10) Immediate bioavailability of $\mathrm{Cr}$ would be controlled through oxidation by manganese oxides, but long-term control would probably be exerted by organic matter and iron oxides. Some enrichment in these soil components is to be expected.

11) Qualitatively, it appears that much of the soil chemistry of $\mathrm{Cr}$ is sufficiently similar to that of $\mathrm{Pu}$, so that it could be used as a general model for $\mathrm{Pu}$ behavior in soil under certain conditions. This is supported by the fact that even though soils with dissimilar properties were used in the experiments, both elements underwent similar reactions. However, there are insufficient data available for both elements to formulate a mathematical model for Pu dispersion based on experiments with $\mathrm{Cr}$.

12) The main points of similarity between $\mathrm{Cr}$ reactions in soil and $\mathrm{Pu}$ reactions in soil are: 
a) Even though the oxides and hydroxides of both elements are unstable in many soil environments they are resistant to weathering so dissolution is slow.

b) The lower valence states of both elements can be sorbed by iron oxides and other soil minerals and can form stable soluble and insoluble organometallic complexes. In these forms the elements cannot be oxidized by manganese oxide minerals.

c) Even though the total amounts and concentrations of $\mathrm{Cr}$ would typically be higher in cases of $\mathrm{Cr}$ contamination of soils than in cases of Pu concaminatinn, nnly a small frattion of the amount of each element is oxidized by manganese oxide minerals.

d) The oxfdation of $\mathrm{Cr}$ and $\mathrm{Pu}$ by manganese oxides could effectively serve to deliver these elements to the vicinity of plant roots for possible uptake.

13) Major points of difference between the two elements are:

a) If the $\mathrm{Cr}$ concentration is high enough, the amount of $\mathrm{Cr}$ oxidizad can bc limited by the amuunt of $\mathrm{MnO}_{2}$ surface area available for oxidation. It is doubtful that $\mathrm{Pu}$ concentrations in soil solutions would ever be high enough to use up the available $\mathrm{MnO}_{2}$ surfare area.

B) Radiolytic effects from $\mathrm{PuO}_{2}$ are absent from $\mathrm{Cr}$. 


\section{LITERATURE CITED}

Allison, L. E. 1965. Organic carbon. In C. A. Black (ed.) Methods of soil analysis. Part II: Chemical and microbiological properties. Agronomy Monograph 9:1367-1378. Am. Soc. of Agron., Madison, Wis.

Anderson, J. V. 1963. An improved pretreatment for mineralogical analysis of samples containing organic matter. Clays Clay Miner. 10:380-388.

Baes, C. F., Jr. and R. F. Mesmer. 1976. The hydrolysis of cations. John Wiley and Sons, New York.

Baker, D. E., M. C. Amacher, and W. T. Doty. 1977. Monitoring sewage sludges, soils, and crops for zinc and cadmium. p. 261-281. In R. C. Loehr (ed.) Proc. 1976 Cornell Agri. Waste Mngmt. Conf. Rochester, N.Y. Oct. 1976. Ann Arbor Science, Ann Arbor, Mich.

Baker, D. E., M. C. Amacher, and R. M. Leach. 1979. Sewage sludge as a source of cadmium in soll-plant-animal systems. Environ. Heal th Persp. 28:45-49.

Baker, D. E., K. K. S. Pillay, A. W. Rose, and E. J. Ciolkosz. 1978. Development of an approach for monitoring the plant availability of transuranics in Nevada Test Site soils. p. 157-176. In M. G. White and P. B. Dunaway (eds.) Selected environmental plutonium research reports of the NAEG. USDOE Rep. NVO-192.

Barber, S. A. 1962. A diffusion and mass-flow concept of soil nutrient availability. Soil Sci. 93:39-45.

Bartlett, R. J. 1981. Oxidation-reduction status of aerobic soils. p. 77-102. In R. H. Dowdy (ed.) Chemistry in the soil environment. ASA Special Publication No. 40. Am. Soc. of Agron., Madison, Wis.

Bartlett, R. J. and B. James. 1979. Behavior of chromium in soils: III. Oxidation. J. Environ. Qual. 8:31-35.

Bartlett, R. J. and B. James. 1980. Studying dried, stored soil samples--some pitfalls. Soil Sci. Soc. Am. J. 44:721-724.

Bartlctt, R. J. and J. M. Kimhle. 1976a. Behavior of chromium in soils: I. Trivalent forms. J. Environ. Qual. 5:379-383.

Bartlett, R. J. and J. M. Kimble. 1976b. Behavior of chromium in soils: II. Hexavalent forms. J. Environ. Qual. 5:383-386.

Bondietti, E. A. and S. A. Reynolds. 1976. Field and laboratory observations on plutonium oxidation states. p. 505-537. In L. L. Ames (ed.) Proc. Workshop on Actinide-Sediment Interactions. Seattle, Wash. 10-11 Fob. 197h. Rattelle Pacffic Northwest Lab, Richland, Wash. USDOE Rep. BNWL-2117. 
Bondietti, E. A., S. A. Reynolds, and M. H. Shanks. 1975. Interactions of plutonium with complexing substances in soils and natural waters. p. 273-287. In Int. Atomic Energy Agency, Vienna (ed.) Transuranium nuclides in the environment. IAEA-SM-191/51.

Bondietti, E. A. and F. H. Sweeton. 1977. Transuranic speciation in the environment. p. 449-476. In M. G. White and P. B. Dunaway (eds.) Transuranics in natural environments. Proc. Symp. on Transuranics in Terrestrial and Aquatic Environ. Gatlinberg, Tenn. 5-7 Oct. 1976. USDOE Rep. NVO-178.

Bremner, J. M. and H. Lees. 1949. Studies on soil organic matter: II. The extraction of organic matter from soil by neutral reagents. J. Agr. Sci. 39:274-279.

Chao, L. L. 1972. Selective dissolution of manganese oxides from soils and sediments with acidified hydroxylamine hydrochloride. Soil Sc1. Soc. Am. Proc. 36:764-768.

Clevcland, J. M. 1970. The chemistry of plutonium. Gordon and Breach Sci. Publ., New York.

Dahlman, R, C., E. A. Bondietti, and L. D. Eyman. 1976. Biological pathways and chemical behavior of plutonium and other actinides in the environment. p. 47-80. In A. M. Friedman (ed.) Actinides in the environment. Am. Chem. Soc. Symp. Series No. 35. Am. Chem. Soc., Washington, D.C.

Doty, W. T., D. E. Baker, and R. F. Shipp. 1977. Chemical monitoring nf sewage oludge in Peunsyvlañia. J. Environ. Qual. 6:421-426.

Essington, E. H., R. O. Gilbert, L. L. Eherhardt, and E. B. Füler. 1976. Plutonium, americium, and uranium concentrations in Nevada Test Site soil profiles. p. 157-173. In Tnt. Atomic Éucryy Agency, Vienna (ed.) Transuranium nuclides in the environment. IAEA-SM-199/76.

Fiskell, J. G. A. 1965. Copper. In C. A. Black (ed.) Methods of soil analysis. Part II: Chemical and microhiologlial properties. Agriunomy Monograph 9:1078-1089. Am. Soc. of Agron., Madison, Wis.

Gardner, W. H. 1965. Water content. In C. A. Black (ed.) Methods of soil analysis. Part I: Physical and mineralogical properties. Agronomy Monograph 9:82-127. Am. Soc. of Agron., Mad1son, Wis.

Garrels, R. M. and C. L. Chr1st. 1965. Solutions, minerals, and equilibria. Freeman, Cooper, and Co. San Francisco, Cal.

Grove, J. H. and B. G. Ellis. 1980. Extractable chromium as related to suil pH and applied chromium. Soil Sci. Soc. Am. J. 44:238-242.

Healy, T. W., A. P. Herring, and D. W. Fuerstenau. 1965. The effect of crystal structure on the surface properties of a series of manganese dioxides. J. Coll. Interf. Sci. 21:435-444. 
Jacobsen, L. and R. Overstreet. 1948. The uptake of plutonium and some products of nuclear fission adsorbed on soil colloids. Soil Sci. 65:129-134.

Lavkulich, L. M. and J. H. Wiens. 1970. Comparison of organic matter destruction by $\mathrm{H}_{2} \mathrm{O}_{2}$ and $\mathrm{NaOCl}$ and its effect on selected mineral constituents. Soil Sci. Soc. Am. Proc. 34:755-758.

Leavitt, V. D. 1970. Soil survey of Area 18, Nevada Test Site. Public Health Service. USDHEW, Washington, D.C.

Lindsay, W. L. 1979. Chemical equilibria in soils. John Wiley and Sons, New York.

Loganathan, P. and R. G. Burau. 1973. Sorption of heavy metal ions by a hydrous manganese oxide. Geochim. Cosmochim. Acta. 37: 1277-1293.

McKenzie, R. M. 1977. Manganese oxides and hydroxides. p. 181-193. In J. B. Dixon and L. B. Weed (eds.) Minerals in soil environments. Soil Sci. Soc. of Am., Madison, Wis.

Mehra, O. P. and M. L. Jackson. 1960. Iron oxide removal from soils and clays by a dithionite-citrate system with sodium bicarbonate. Clays Clay Miner. 7:317-327.

Morgan, J. J. and W. Stumm. 1964. Colloid-chemical properties of manganese dioxide. J. Colloid Sci. 19:347-359.

Mubarak, A. and R. A. 01sen. 1976. Immiscible displacement of the soil solution by centrifugation. Soil Sci. Soc. Am. Proc. 40: $327-329$.

Murray, D. J., T. W. Healy, and D. W. Fuerstenau. 1968. The adsorption of aqueous metal ions on colloidal manganese oxide. Adv. Chem. Ser. 79:74-81.

Pearre, N. C. and A. V. Heyl. 1960. Chromite and other mineral deposits in serpentine rocks of the Piedmont Upland Maryland, Pennsylvania, and Delaware. U.S. Geol. Sur. Bull. 1082-K. U.S. Gov. Printing Office, Washington, D.C.

Posselt, H. S., F. J. Anderson, and W. J. Weber, Jr. 1968. Cation sorption on colloidal hydrous manganese dioxide. Environ. Sci. Tech. 2:1087-1093.

Rai, E. and R. J. Serne. 1977. Plutonium activities in soil solutions and the stability and formation of selected plutonium minerals. J. Environ. Qual. 6:89-95.

Rai, D. R., R. J. Serne, and D. A. Moore. 1980. Solubility of plutonium compounds and their behavior in soils. Soil Sci. Soc. Am. J. 44:490-495. 
Rai, D., R. J. Serne, and J. L. Swanson. 1980. Solution species of plutonium in the environment. J. Environ. Qual. 9:417-420.

Stevenson, F. J. 1965. Gross chemical fractionation of organic matter. In C. A. Black (ed.) Methods of soil analysis. Part II: Chemical and microbiological properties. Agronomy Monograph 9:1409-1421. Am. Soc. of Agron., Madison, Wis.

Tamura, T. 1974. Distribution and characterization of plutonium in soils from the Nevada Test Site. p. 29-42. In M. G. White and P. B. Dunaway (eds.) The dynamics of plutonium in desert environments. USDOE Rep. NVO-142.

Tamura, T. 1975. Characterization of plutonium in surface soils from Area 13 of the Nevada Test Site. p. 27-41. In M. G. White and P. B. Dunaway (eds.) The dynamics of plutonium in desert environment3. USDOE Rep. NVO-153.

Taylor, R. M. and R. M, McKenzie. 1966. The association of trace elénenls and manyanese minerals in Australian soils. 'Aust. J." Soil Res. 4:29-39.

United Stcates Environmental Protertion Agency. 1980. Revicwo of the environmental effects of pollutants: III. Chromium. ORNL/EIS-80. EPA-600/1-78-023.

Wedepohl, K. H. (ed.). 1970. Handbook of geochemistry. SpringerVerlag, Berlin.

White, M. G. and P. B. Dunaway (eds.). 1975. The radioecology of plutonium and other transuranics in desert environments. USDOE Rep. NVO-153.

White, M. G. and P. B. Dunaway (eds.). 1976. Studies of environmental plutonium and other transuranics in desert ecosystems. USDOE Rep. NVO-159.

White, M. G. and P. B. Dunaway (eds.). 1977a. Environmental plutonium on the Nevada Test Site and environs. USDOE Rep. NVO-171.

White, M. G. and P. B. Dunaway (eds.). 1977b. Transuranics in desert ecosystems. USDOE Rep. NVO-181.

White, M. G. and P. B. Dunaway (eds.). 1978. Selected environmental plutonium research reports of the NAEG. USDOE Rep. NVO-192.

Wong, K. M., V. E. Noshkin, and T. A. Jokela. 1978. Preconcentration of plutonium radionuclides from natural waters. p. 583-592. In M. G. White and P. B. Dunaway (eds.) Selected environmental plutonium research reports of the NAEG. USDOE Rep. NVO-192. 